Інститут вищої освіти НАПН України

Відділ інтернаціоналізації вищої освіти

\title{
Стратегії вищої освіти \\ в умовах інтернаціоналізації \\ для стійкого розвитку суспільства
}

Методичні рекомендації 
УДК 378.4:37.014.25

ISBN 978-617-7486-31-1

https://doi.org/10.31874/978-617-7486-31-1-2019

Рекомендовано до друку рішенням вченої ради

Інституту вищої освіти НАПН України

(від 27 грудня 2019 р., протокол № 14/3)

Стратегії вищої освіти в умовах інтернаціоналізації для стійкого розвитку суспільства: методичні рекомендації / В. Зінченко, Л. Горбунова, С. Курбатов, Ю. Мєлков ; за ред. В. Зінченка ; макет та редагування О. Шипко. Київ : Інститут вищої освіти НАПН України, 2019. 107 с.

Методичні рекомендації сформульовано на основі аналізу провідного досвіду впровадження стратегій вищої освіти в умовах інтернаціоналізації для стійкого розвитку суспільства.

Матеріали сприятимуть якісному формуванню та впровадженню моделей освіти для стійкого розвитку, освіти у сфері глобального громадянства та відповідних концепцій і прикладних моделей, котрі повинні навчити тим компетентностям, які зможуть допомогти у трансформації інститутів освіти та науки у розвитку глобального світу для спільної співпраці. Комплексні компетенції такого ґатунку можуть бути розроблені за допомогою навчальних моделей, освітніх принципів та вирішення науково-освітніх проблем, закладених в існуючих системах освіти.

Для науковців у галузі вищої освіти, суспільствознавства, філософії освіти і педагогіки, викладачів, докторантів, аспірантів і студентів закладів вищої освіти.

(C) Інститут вищої освіти НАПН України, 2019

(C) Колектив авторів, 2019 


\section{Зміст}

Вступ.

Розділ І. Інтернаціоналізація вищої освіти України (за результатами загальнонаціонального опитування «Перспективи та потреби розвитку університетів України у процесі реформування вищої освіти у контексті європейської інтеграції»)

Інформація про заклади вищої освіти України, які взяли участь в опитуванні, та респондентів ....................7

Запитання: До яких напрямів інтернаціоналізації, які реалізуються у Вашому 3ВО,

Ви особисто залучені?

Запитання: До яких напрямів інтернаціоналізації, які реалізуються у Вашому 3ВО,

Ви особисто залучені?

Запитання: Яка допомога надається науково-педагогічним працівникам Вашого 3ВО

для сприяння їх участі у міжнародній співпраці?

Запитання: Хто здійснює розроблення проектних заявок для участі у програмах

міжнародної співпраці у Вашому ЗВО?

Розділ II. Наукометричні показники, ранжування та наукова ідентифікація

як фактори інтернаціоналізації вищої освіти і науки у контексті стійкого розвитку

Інтернаціональні показники науково-дослідницької діяльності та ідентифікатори вченого.........................17

Наукометричні системи як основа науково-освітньої інтернаціоналізації ..................................................220

Проблемні аспекти розвитку наукометричних систем у освітньо-науковому просторі

розвинених та транзитивних країн та перспективи посилення їхньої ефективності

і відкритості як фактор стійкого розвитку

Пропонована класифікація міжнародних систем цитування (наукометричних систем

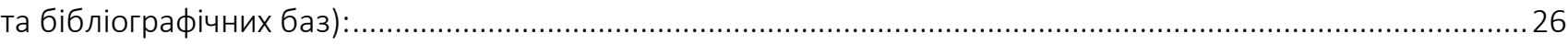

Структуризація та класифікація наукометричного інструментарію, систем, баз, методів ...........................27

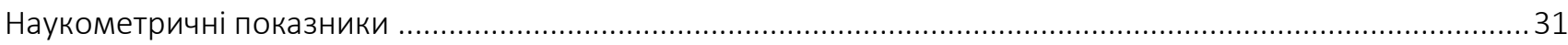

Інструментарій інтернаціоналізації освітньо-наукової діяльності ..........................................................33

Нагальні питання, висновки та пропозиції по розвитку інтеграції вищої освіти України

до сучасної глобально-інтернаціональної системи наукометричного інструментарію якості......................34

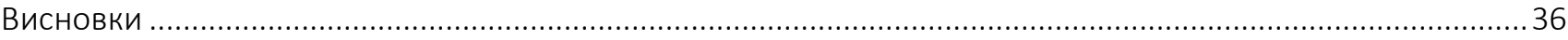

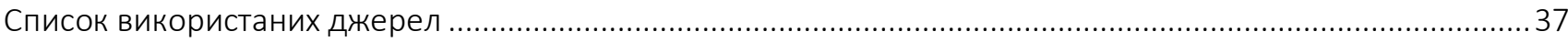

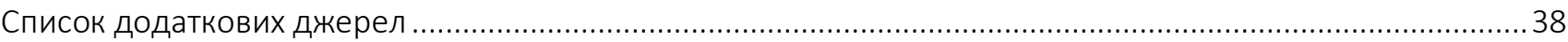

Розділ III. Освіта для стійкого розвитку: рекомендації до впровадження

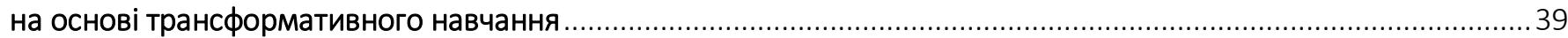

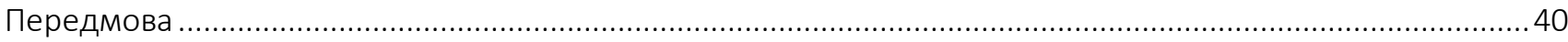

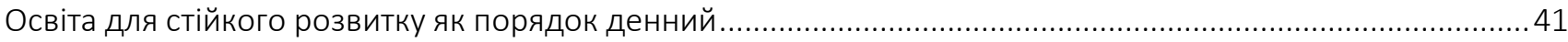

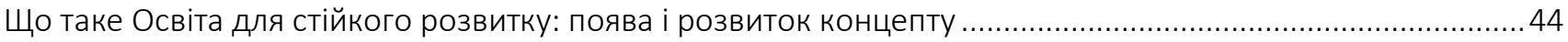

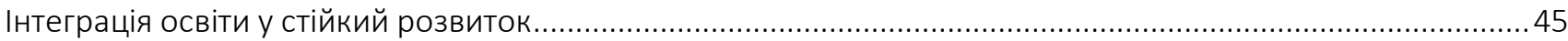

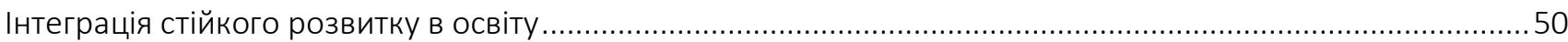

Глобальна програма дій в області Освіти для стійкого розвитку (GAP on ESD) …...................................53

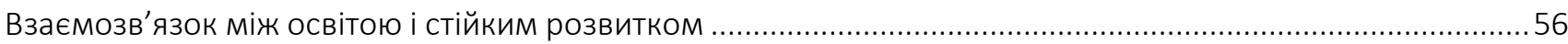

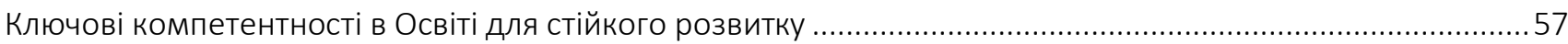

Освіта для стійкого розвитку (ESD) як трансформативна і заснована на компетентностях..........................58

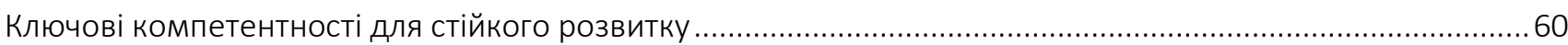

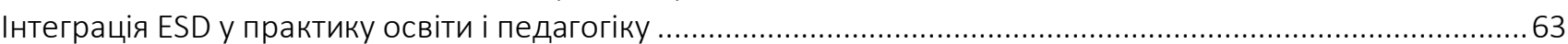

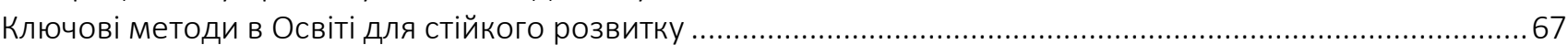

Оцінювання результатів навчання в Освіті для стійкого розвитку (ESD) ……......................................68

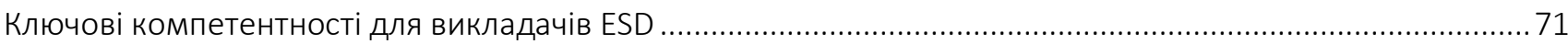

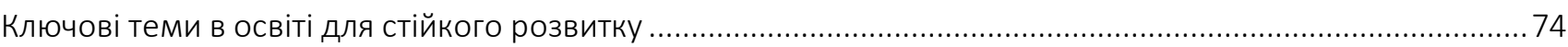

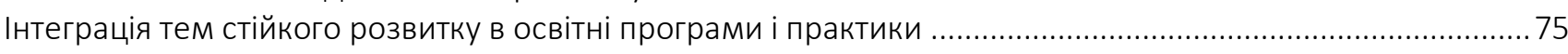

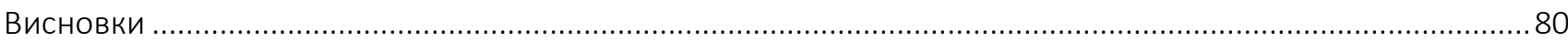

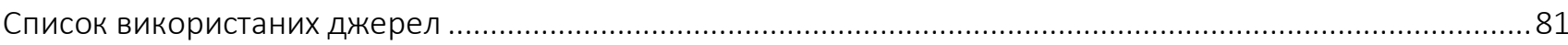


Розділ IV. Стратегії вищої освіти в умовах інтернаціоналізації для стійкого розвитку:

проблема якості

Якісні виміри стратегії інтернаціоналізації закладу вищої освіти ...................................................... 86

Входження закладів вищої освіти до баз даних провідних міжнародних

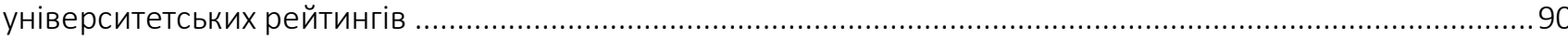

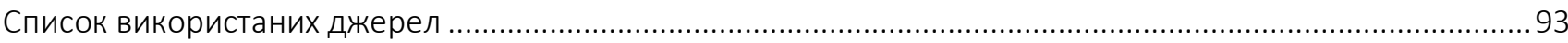

Розділ V. Особистісні та гуманістичні стратегії вищої освіти для стійкого розвитку:

шляхи реалізації

Стійкий розвиток і його реалізація у вищій освіті: постановка проблеми

та аналіз існуючих підходів 96

Особистісний вимір освіти для стійкого розвитку: від гасел до реалізації .................................................98

Інституціональні зрушення та новий вимір місії університету як фактор реалізації

освіти для стійкого розвитку

Висновки та рекомендації щодо можливих напрямів реалізації вищої освіти

для стійкого розвитку

Список використаних джерел 


\section{Вступ}

Методичні рекомендації «Стратегії вищої освіти в умовах інтернаціоналізації для стійкого розвитку суспільства» підготовлено колективом авторів на основі аналізу провідного досвіду впровадження стратегій вищої освіти в умовах інтернаціоналізації для стійкого розвитку суспільства.

У розділі «Інтернаціоналізація вищої освіти України» представлено результати загальнонаціонального опитування «Перспективи та потреби розвитку університетів України у процесі реформування вищої освіти у контексті європейської інтеграції», проведеного серед науково-педагогічних працівників та здобувачів закладів вищої освіти. Результати опитування демонструють напрямки інтернаціоналізації 3ВО, рівень залученості та підтримки респондентів у міжнародної діяльності.

Розділ ॥ «Наукометричні показники, ранжування та наукова ідентифікація як фактори інтернаціоналізації вищої освіти і науки у контексті стійкого розвитку» висвітлює одну з провідних цілей наукометричних показників та даних у контексті інтернаціоналізації інституцій та установ вищої освіти і науки України - включення до міжнародної, глобальної науково-освітньої системи якомога більшої кількості релевантних наукових спільнот, колективів науковців, дослідників та їх наукових праць, розробок, інновацій і рейтингування їх за певними об'єктивними показниками.

Наукометрична система і їі різноманітні складові, зокрема, так звані «бази даних» - це аналітична, порівняльно-ранжувальна («індексувально-рейтингова»), бібліографічна і реферативна система науководослідних даних, інструмент для відстеження цитованості наукових публікацій та інших результатів наукової і науково-дослідницької діяльності. Наукометрична база даних - це також і пошукова система, яка формує статистику, що характеризує стан і динаміку показників затребуваності, активності та індексів впливу діяльності окремих вчених і дослідницьких організацій.

Виникнення наукометричних баз (систем, платформ) є природнім явищем у розвитку суспільства як спроба виміряти те, що з одного боку $\epsilon$ абстрактним, а з іншого - в результаті глибокого аналізу характеризується певними кількісними ознаками. Наукові дослідження зумовлюють прискорений розвиток технологій, отже на певному етапі виникла необхідність оцінити, тобто виміряти вагомість науководослідницького внеску вченого для розвитку певної галузі досліджень. Оскільки цю потребу відчули в різних країнах з відносно невеликою різницею у часі, були винайдені і розроблені різні наукометричні технології.

щоб підвищити наукометричні показники, за якими проводяться кількісні оцінки і порівняльний аналіз наукової активності авторів та наукових установ, потрібно публікуватися у закордонних і вітчизняних журналах, що входять до відомих наукометричних систем/баз, реєструватися й створювати свій авторський профіль в міжнародних наукометричних базах.

У розділі III «Освіта для стійкого розвитку: рекомендації до впровадження на основі трансформативного навчання» рекомендації сформульовані на основі аналізу документів міжнародних організацій та окремих інституціональних досліджень досвіду впровадження Освіти для стійкого розвитку (ESD - Education for Sustainable Development) на основі трансформативного навчання, яка дає учням можливість приймати усвідомлені рішення і проводити відповідальні заходи для забезпечення екологічної цілісності, економічної життєздатності і справедливого суспільного устрою для нинішнього і майбутніх поколінь при повазі культурного розмаїтя. ESD сприяє цілісній і трансформативній освіті. Цей тип освіти стосується змісту і результатів навчання, інноваційної педагогіки і «навчання на практиці» («learning by doing») і використовує цілісний загальноінституціональний підхід для залучення спільнот в досягнення стійких змін. ESD знаходиться у центрі Порядку денного у галузі стійкого розвитку на період до 2030 року і отримала широке визнання у якості ключового фактора стійкого розвитку і невід'ємного елементу якісної освіти. Він є частиною Цілі 4 в області стійкого розвитку, яка до 2030 року прагне забезпечити те, щоб всі учні придбали знання і навички, необхідні для сприяння стійкому розвитку, в тому числі за допомогою освіти для стійкого розвитку та стійкого способу життя, а також пронизує всі інші цілі у галузі стійкого розвитку (SDGs Sustainable Development Goals).

Рекомендації включають в себе: обґрунтування впровадження ESD в українську освіту як порядку денного для ії реформування на основі документів UN, UNESCO, OECD та досліджень новітнього міжнародного досвіду трансформативного навчання у закладах вищої освіти; аналіз змісту концепта Освіти для стійкого розвитку та його еволюції, тенденції інтеграції освіти у стійкий розвиток та роль освіти у досягненні цілей стійкого розвитку; розглянута Глобальна програма дій в області Освіти для стійкого розвитку; проаналізована дискусія стосовно ключових компетентностей, які має надавати Освіта для стійкого розвитку; визначені ключові теми і результати навчання, а також орієнтації щодо викладання, навчання та 
оцінювання, тобто того, як допомогти студентам у досягненні ними відповідних результатів і вмінні продемонструвати їх.

Розділ IV «Стратегії вищої освіти в умовах інтернаціоналізації для стійкого розвитку: проблема якості» присвячено методичним рекомендаціям, які стосуються розробки стратегій інтернаціоналізації закладів вищої освіти, спираючись на підходи, сформовані у англомовній академічній літературі, а також досвід українських та зарубіжних університетів. Передбачено, що подібна стратегія має три рівні: 1) глобальний, який тлумачиться у контексті парадигми сталого розвитку із акцентом на Резолюцію Організації Об'єднаних Націй «Перетворення нашого світу: порядок денний в області сталого розвитку на період до 2030 року» та мережеву ініціативу The United Nations Academic Impact (UNAI); 2) регіональний або національний, який, в українському контексті, визначають підходи та практики Європейського простору вищої освіти та Європейського дослідницького простору та 3) інституційний, обумовлений специфікою діяльності конкретного закладу вищої освіти та його місією. Відповідні положення проілюстровані підходами, які покладено в основу прийнятої у 2019 році стратегії інтернаціоналізації Сумського державного університету одного із інституційних лідерів вітчизняної системи вищої освіти. Зроблено акцент на ролі провідних міжнародних університетських рейтингів - Academic Ranking of World Universities (ARWU) або Шанхайському рейтингу, QS World University Rankings або рейтингу QS та THE World University Rankings або рейтингу Таймс у процесах інтернаціоналізації вищої освіти та забезпечення ії якості. Також розглянуто процес входження закладів вищої освіти до баз даних цих рейтингів.

У розділі V «Особистісні та гуманістичні стратегії вищої освіти для стійкого розвитку: шляхи реалізації» розглянуто можливі шляхи реалізації стратегій вищої освіти в умовах інтернаціоналізації для стійкого розвитку суспільства у ЗВО України. Висловлені методичні рекомендації ґрунтуються на теоретичній концепції, згідно з якою соціальний, економічній та екологічний вектори подальшого поступу суспільства поєднуються в одній площині стійкості завдяки всебічному розвитку людської особистості, яка виступає носієм і суб'єктом суспільних цінностей, яка здатна втілювати відповідні настанови у власній життєдіяльності та формування якої є загальною метою сучасного університету. В якості запропонованих можливих практик підготовки подібної особистості виступають такі розглянуті напрями, як-от: екологічна освіта; реалізація інвайронменталістського підходу в управлінні університетським кампусом та стратегія деурбанізації ЗВО; деформалізація та індивідуалізація навчального процесу в дусі навчання, «центрованого» на особистості; гуманітаризація навчальних програм з акцентом на формування критичного мислення; застосування постнекласичної методології як засобу, що уможливлює конкретне мислення «єдності в багатоманітності»; та активне застосування Інтернет-технологій і онлайн-платформ. 
Розділ І. Інтернаціоналізація вищої освіти України

(за результатами загальнонаціонального опитування

«Перспективи та потреби розвитку університетів України у процесі реформування вищої освіти у контексті європейської інтеграції» ${ }^{1}$ )

\section{Інформація про заклади вищої освіти України, які взяли участь в опитуванні, та респондентів}

Участь в опитуванні взяли 37 3ВО, з них: державних - 33, приватних - 2, комунальних - 2. Відповіді на запитання запропонованої для опитування анкети надавалися науково-педагогічними працівниками закладів вищої освіти (які додатково віднесені до двох категорій - управлінці та викладачі / дослідники), а також здобувачами вищої освіти (студенти / аспіранти).

\section{Список університетів, які взяли участь в опитуванні із зазначенням груп респондентів}

Табл. 1.1

\begin{tabular}{|c|c|c|c|c|c|c|}
\hline № & Назва ЗВО & Управлінці & $\begin{array}{l}\text { Викладачі / } \\
\text { дослідники }\end{array}$ & $\begin{array}{l}\text { Студенти / } \\
\text { аспіранти }\end{array}$ & $\begin{array}{c}\text { Всього } \\
\text { респондентів }\end{array}$ & Всього НПП \\
\hline 1 & $\begin{array}{l}\text { Вінницький державний педагогічний } \\
\text { університет імені Михайла Коцюбинського }\end{array}$ & 5 & 15 & 5 & 25 & 20 \\
\hline 2 & $\begin{array}{l}\text { Вінницький національний медичний } \\
\text { університет ім. М.І. Пирогова }\end{array}$ & 5 & 20 & 5 & 30 & 25 \\
\hline 3 & $\begin{array}{l}\text { Вінницький національний технічний } \\
\text { університет }\end{array}$ & 9 & 23 & 2 & 34 & 32 \\
\hline 4 & $\begin{array}{l}\text { Глухівський національний педагогічний } \\
\text { університет імені Олександра Довженка }\end{array}$ & 3 & 13 & 8 & 24 & 16 \\
\hline 5 & Донецький державний університет управління & 5 & 18 & 5 & 28 & 23 \\
\hline 6 & $\begin{array}{l}\text { Донецький національний технічний } \\
\text { університет }\end{array}$ & 8 & 17 & 4 & 29 & 25 \\
\hline 7 & $\begin{array}{l}\text { Донецький національний університет імені } \\
\text { Василя Стуса }\end{array}$ & 3 & 14 & 10 & 27 & 17 \\
\hline 8 & $\begin{array}{l}\text { Київський національний економічний } \\
\text { університет ім. Вадима Гетьмана }\end{array}$ & 5 & 20 & 5 & 30 & 25 \\
\hline 9 & $\begin{array}{l}\text { Київський національний університет } \\
\text { технологій та дизайну }\end{array}$ & 8 & 11 & 3 & 22 & 19 \\
\hline 10 & Київський університет імені Бориса Грінченка & 5 & 16 & 5 & 26 & 21 \\
\hline 11 & $\begin{array}{l}\text { Луганський національний аграрний } \\
\text { університет }\end{array}$ & 11 & 19 & 10 & 40 & 30 \\
\hline 12 & Луцький національний технічний університет & 5 & 21 & 6 & 32 & 26 \\
\hline 13 & $\begin{array}{l}\text { Львівський національний університет імені } \\
\text { Івана Франка }\end{array}$ & 6 & 17 & 6 & 29 & 23 \\
\hline 14 & Маріупольський державний університет & 5 & 16 & 5 & 26 & 21 \\
\hline 15 & Національний авіаційний університет & 6 & 19 & 5 & 30 & 25 \\
\hline 16 & $\begin{array}{l}\text { Національний аерокосмічний університет ім. } \\
\text { М.Є. Жуковського «Харківський авіаційний } \\
\text { інститут» }\end{array}$ & 7 & 13 & 4 & 24 & 20 \\
\hline 17 & $\begin{array}{l}\text { Національний педагогічний університет імені } \\
\text { М.П. Драгоманова }\end{array}$ & 1 & 13 & 4 & 18 & 14 \\
\hline 18 & $\begin{array}{l}\text { Національний технічний університет } \\
\text { «Харківський політехнічний інститут» }\end{array}$ & 3 & 31 & 5 & 39 & 34 \\
\hline 19 & $\begin{array}{l}\text { Національний технічний університет } \\
\text { «Дніпровська політехніка» }\end{array}$ & 7 & 8 & 0 & 15 & 15 \\
\hline 20 & $\begin{array}{l}\text { Національний університет водного } \\
\text { господарства та природокористування }\end{array}$ & 0 & 21 & 0 & 21 & 21 \\
\hline
\end{tabular}

\footnotetext{
${ }^{1}$ Результати загальнонаціонального опитування «Перспективи та потреби розвитку університетів України у процесі реформування вищої освіти у контексті європейської інтеграції» / Авторський колектив; за заг. ред. С. Калашнікової. - Київ: Інститут вищої освіти НАПН України, 2019. - 77 с. Міжнародний науковий журнал «Університети і лідерство». № 2(8) (2019). - С. 144-220. URL: https://ul-journal.org/index.php/journal/article/view/105/98
} 


\begin{tabular}{|c|c|c|c|c|c|c|}
\hline № & Назва ЗВО & Управлінці & $\begin{array}{l}\text { Викладачі / } \\
\text { дослідники }\end{array}$ & $\begin{array}{l}\text { Студенти / } \\
\text { аспіранти }\end{array}$ & $\begin{array}{c}\text { Всього } \\
\text { респондентів }\end{array}$ & Всього НПП \\
\hline 21 & $\begin{array}{l}\text { Національний університет «Львівська } \\
\text { політехніка» }\end{array}$ & 3 & 2 & 22 & 27 & 5 \\
\hline 22 & $\begin{array}{l}\text { Національний університет «Одеська юридична } \\
\text { академія» }\end{array}$ & 7 & 14 & 8 & 29 & 21 \\
\hline 23 & $\begin{array}{l}\text { Національний університет «Острозька } \\
\text { академія» }\end{array}$ & 6 & 14 & 0 & 20 & 20 \\
\hline 24 & $\begin{array}{l}\text { Національний університет «Чернігівський } \\
\text { колегіум» імені Т.Г. Шевченка }\end{array}$ & 7 & 16 & 7 & 30 & 23 \\
\hline 25 & $\begin{array}{l}\text { Полтавський національний педагогічний } \\
\text { університет імені В.Г. Короленка }\end{array}$ & 6 & 18 & 5 & 29 & 24 \\
\hline 26 & Полтавський університет економіки і торгівлі & 14 & 13 & 5 & 32 & 27 \\
\hline 27 & Сумський державний університет & 13 & 13 & 5 & 31 & 26 \\
\hline 28 & $\begin{array}{l}\text { Східноєвропейський національний } \\
\text { університет імені Лесі Українки }\end{array}$ & 1 & 24 & 0 & 25 & 25 \\
\hline 29 & $\begin{array}{l}\text { Східноукраїнський національний університет } \\
\text { імені Володимира Даля }\end{array}$ & 5 & 17 & 18 & 40 & 22 \\
\hline 30 & $\begin{array}{l}\text { Таврійський національний університет імені } \\
\text { В.І. Вернадського }\end{array}$ & 4 & 12 & 8 & 24 & 16 \\
\hline 31 & $\begin{array}{l}\text { Тернопільський національний технічний } \\
\text { університет імені Івана Пулюя }\end{array}$ & 8 & 6 & 5 & 19 & 14 \\
\hline 32 & Ужгородський національний університет & 4 & 34 & 3 & 41 & 38 \\
\hline 33 & $\begin{array}{l}\text { Харківський гуманітарний університет } \\
\text { «Народна українська академія» }\end{array}$ & 6 & 19 & 5 & 30 & 25 \\
\hline 34 & $\begin{array}{l}\text { Харківський національний економічний } \\
\text { університет імені Семена Кузнеця }\end{array}$ & 6 & 20 & 5 & 31 & 26 \\
\hline 35 & $\begin{array}{l}\text { Хмельницька гуманітарно-педагогічна } \\
\text { академія }\end{array}$ & 9 & 29 & 21 & 59 & 38 \\
\hline 36 & $\begin{array}{l}\text { Чернівецький національний університет імені } \\
\text { Юрія Федьковича }\end{array}$ & 7 & 19 & 5 & 31 & 26 \\
\hline \multirow[t]{3}{*}{37} & $\begin{array}{l}\text { Чернігівський національний технічний } \\
\text { університет }\end{array}$ & 10 & 18 & 1 & 29 & 28 \\
\hline & Всього 3 ВО - 37 & Управлінці & $\begin{array}{l}\text { Викладачі / } \\
\text { дослідники }\end{array}$ & $\begin{array}{l}\text { Студенти / } \\
\text { аспіранти }\end{array}$ & $\begin{array}{c}\text { Всього } \\
\text { респондентів }\end{array}$ & Всього НПП \\
\hline & Осіб & 223 & 633 & 220 & 1076 & 856 \\
\hline
\end{tabular}

Заклади представляють 17 регіонів, серед яких провідні університетські центри - Київський, Харківський, Львівський, Одеський, Дніпропетровський і Донецький.

За формалізованими ознаками заклади переважно належать до кращої половини ЗВО України. Серед них 29 (78 \%) національних, 27 (73 \%) обіймають позиції у першій половині рейтингу «Консолідований» 2019 р. 3239 закладів, який інтегрує рейтинги «Топ-200 Україна», «Scopus» та «Бал ЗНО на контракт».

Крім того, Національний університет «Львівська політехніка» входить у групу 801-1000 міжнародного університетського рейтингу «Times», а Національний технічний університет «Харківський політехнічний інститут», Сумський державний університет та згаданий Національний університет «Львівська політехніка» посідають місця 651-800 міжнародного університетського рейтингу «QS». Отже, отримані висновки можна вважати валідними для ЗВО або університетської практики України. 
Запитання: До яких напрямів інтернаціоналізації, які реалізуються у Вашому 3ВО, Ви особисто залучені?

Табл. (рис.) 2.1.

Управлінці (223 особи)

\section{Залученість НПП до напрямів інтерначіоналізації, які реалізуються у 3 ВО}

\begin{tabular}{|l|c|c|}
\hline \multicolumn{1}{|c|}{ Напрями інтернаціоналізації } & Ociб & \% \\
\hline Міжнародні освітні проекти & 116 & 52 \\
\hline Міжнародні наукові проекти & 91 & 41 \\
\hline Міжнародна мобільність адміністративного персоналу & 66 & 30 \\
\hline Спільні освітні програми з подвійними дипломами & 64 & 29 \\
\hline Розвиток англомовної компетентності НПп & 83 & 37 \\
\hline Навчання іноземних здобувачів вищої освіти & 87 & 39 \\
\hline Викладання іноземними мовами профільних навчальних дисциплін & 53 & 24 \\
\hline Спільні наукові публікації із зарубіжними дослідниками & 74 & 33 \\
\hline Залучення іноземних викладачів до викладання навчальних дисциплін & 38 & 17 \\
\hline Міжнародна мобільність викладачів & 73 & 33 \\
\hline
\end{tabular}

\section{Викладачі / дослідники (633 особи)}

\begin{tabular}{|l|c|c|}
\hline \multicolumn{1}{|c|}{ Напрями інтернаціоналізації } & Oсіб & \% \\
\hline Міжнародні освітні проекти & 199 & 31 \\
\hline Міжнародні наукові проекти & 204 & 32 \\
\hline Міжнародна мобільність адміністративного персоналу & 58 & 9 \\
\hline Спільні освітні програми з подвійними дипломами & 111 & 18 \\
\hline Розвиток англомовної компетентності НПп & 157 & 25 \\
\hline Навчання іноземних здобувачів вищої освіти & 198 & 31 \\
\hline Викладання іноземними мовами профільних навчальних дисциплін & 143 & 23 \\
\hline Спільні наукові публікації із зарубіжними дослідниками & 193 & 30 \\
\hline Залучення іноземних викладачів до викладання навчальних дисциплін & 72 & 11 \\
\hline Міжнародна мобільність викладачів & 134 & 21 \\
\hline
\end{tabular}

\section{Залученість НПП до інтернаціоналізації (\%)}

Міжнародні освітні проекти

Міжнародні наукові проекти

Міжнародна мобільність адміністративного персоналу

Спільні освітні програми з подвійними дипломами

Розвиток англомовної компетентності НПП

Навчання іноземних здобувачів вищої освіти

Викладання іноземними мовами профільних навчальних дисициплін

Спільні наукові публікації із зарубіжними дослідниками

Залучення іноземних викладачів до викладання навчальних дисциплін

Міжнародна мобільність викладачів

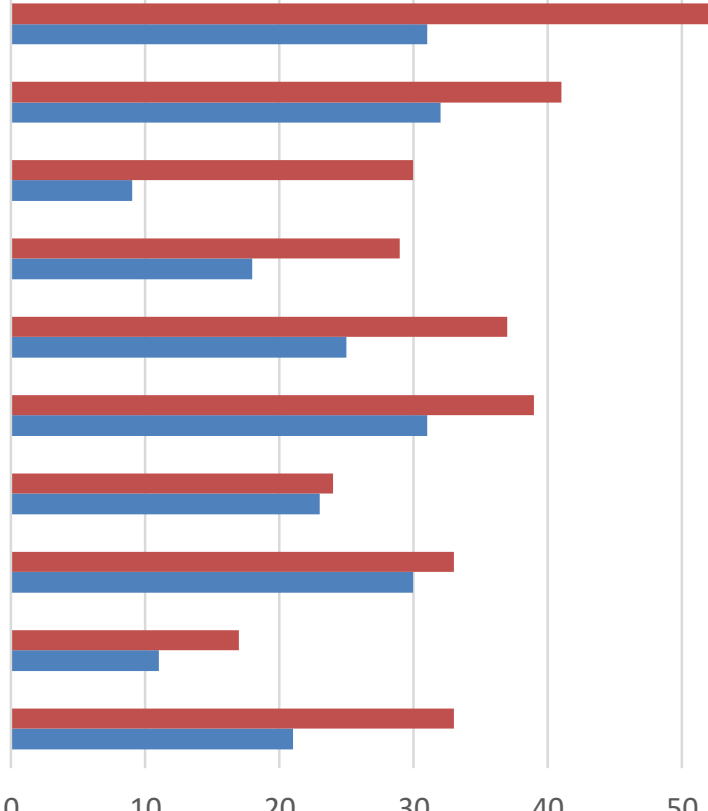


Отримані дані дозволяють стверджувати, що «управлінці» $є$ найбільш залученими до діяльності, пов'язаної із реалізацією міжнародних освітніх / наукових проектів (52\% та 41\% відповідно).

У випадку викладачів / дослідників найбільш значущими та рівноцінними за рівнем залученості виявилися такі чотири напрями інтернаціоналізації вищої освіти:

- міжнародні наукові проекти (32\%);

- міжнародні освітні проекти (31\%);

- навчання іноземних здобувачів вищої освіти (31\%);

- спільні наукові публікації із зарубіжними дослідниками (30\%).

Враховуючи те, що управлінці та викладачі / дослідники надають першочергове значення у процесі інтернаціоналізації освітнім проектам (52\% та 31\% відповідно), науковим проектам (41\% і 32\% відповідно) та спільним публікаціям (33\% і 30\% відповідно), стверджуємо, що спільна науково-освітня діяльність (особливо на професійно-особистісному рівні) розглядається представниками цих академічних груп як найбільш вагомий фактор «зближення, взаєморозуміння і взаємовпливу».

Зазначене вище дозволяє визначити таку «інституційну політику інтернаціоналізації» вітчизняних ЗВО як трансверсальну, таку що сприяє освіті для стійкого розвитку. Поряд із цим, не дуже втішним є той факт, що до участі у спільній науково-освітній діяльності, що базується на особистісно-професійному спілкуванні, залучено лише 30\% викладачів / дослідників. Цей показник $є$ недостатнім для реалізації інтернаціоналізації у контексті сучасних вимог і може розглядатися лише як проміжний результат реалізації «трансформативних стратегій» розвитку вищої освіти України.

Співмірними для управлінців і викладачів / дослідників виявилися такі параметри:

- викладання іноземними мовами профільних навчальних дисциплін (24\% та 23\% відповідно);

- спільні наукові публікації із зарубіжними дослідниками (33\% та 30\% відповідно).

Значну різницю щодо рівня залученості представників цих двох категорій НПП засвідчили кілька напрямів інтернаціоналізації:

- міжнародна мобільність (30\% управлінців проти 21\% викладачів / дослідників);

- розвиток англомовної компетентності НПП (37\% управлінців проти 25\% викладачів / дослідників);

До інших важливих показників у категорії «управлінці», адже понад третини управлінців засвідчують свою залученість до цих напрямів інтернаціоналізації, варто, на наш погляд, віднести:

- навчання іноземних здобувачів вищої освіти (39\%);

- спільні наукові публікації із зарубіжними дослідниками (33\%);

У категорії «викладачі / дослідники» відмітимо той факт, що трошки менше 1/5 представників цієї групи (18\%) на момент проведення опитування залучені до реалізації спільних освітніх програм з подвійними дипломами.

За результатами опитування можна також констатувати у цілому достатній рівень залученості членів академічної спільноти ЗВО України до процесів інтернаціоналізації, оскільки для більшості напрямів інтернаціоналізації цей показник становить близько 30\% і менше. Поряд із цим, варто зазначити, що оцінки за деякими напрямами (спільні освітні програми з подвійними дипломами; спільні наукові публікації із зарубіжними партнерами) є досить високими, що може бути прояснено залученням до опитування найбільш активних у міжнародній діяльності представників НПП. 
Запитання: До яких напрямів інтернаціоналізації, які реалізуються у Вашому 3ВО,

Ви особисто залучені?

Залученість студентів до напрямів інтернаціоналізації,

Табл. (рис.) 2.2. які реалізуються у 3 ВО

Студенти / аспіранти (220 осіб)

\begin{tabular}{|l|c|c|}
\hline \multicolumn{1}{|c|}{ Напрями інтернаціоналізації } & Oсіб & $\%$ \\
\hline Міжнародні освітні проекти & 78 & 35 \\
\hline Міжнародні наукові проекти & 72 & 33 \\
\hline Спільні освітні програми з подвійними дипломами & 35 & 16 \\
\hline Міжнародна мобільність здобувачів ВО & 67 & 30 \\
\hline
\end{tabular}

\section{Залученість студентів до інтернаціоналізації (\%)}

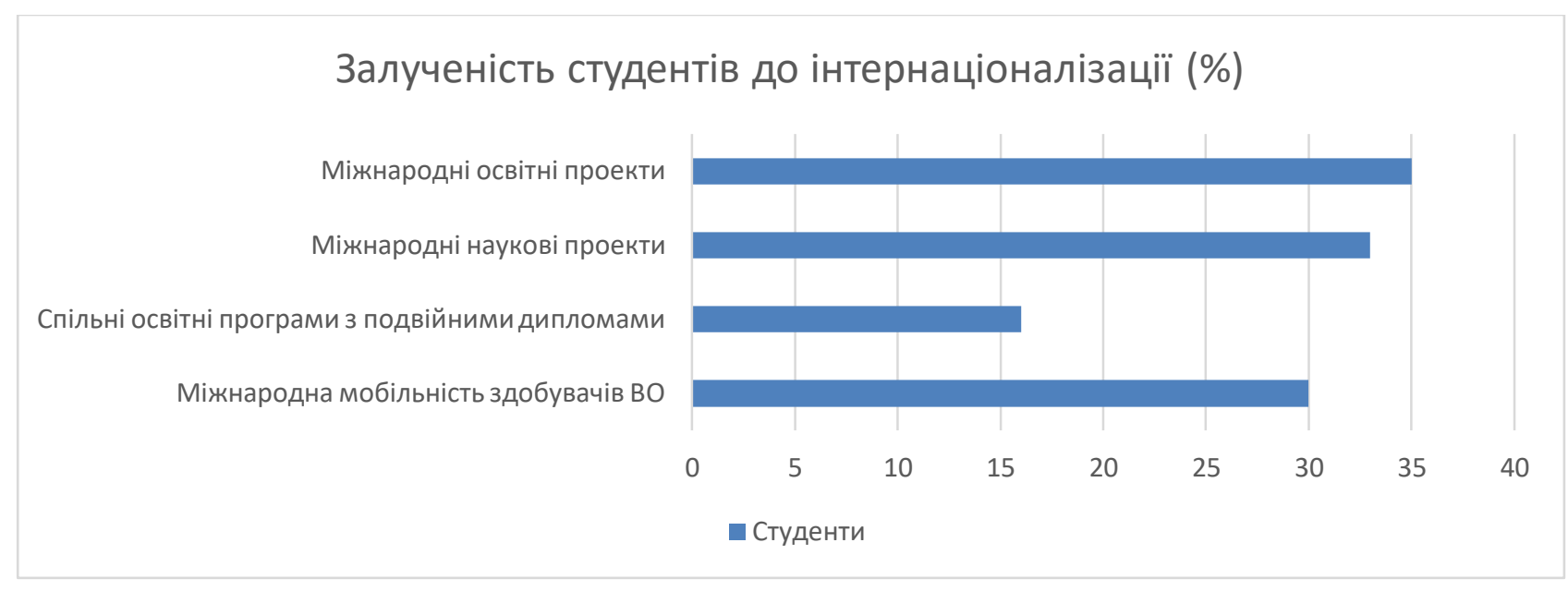

Дані опитування представників здобувачів вищої освіти, засвідчують, що понад третини студентів / аспірантів $€$ залученими до реалізації міжнародних освітніх / наукових проектів (35\% і 33\% відповідно).

Досить високим за результатами опитування виявився показник залученості студентів / аспірантів до міжнародної мобільності, що складає 30\% представників цієї категоріальної групи. При цьому варто додатково зазначити, що типи та терміни міжнародної мобільності не були обумовлені критеріями.

Порівнюючи дані щодо студентів / аспірантів з даними щодо НПП, констатуємо, що рівні залученості до напряму інтернаціоналізації вищої освіти «міжнародні проекти» та до напряму «спільні освітні програми 3 подвійними дипломами» є співмірним для цих двох груп (35\% проти 31\%; 16\% проти 18\%). У той же час, міжнародна мобільність серед здобувачів вищої освіти є дещо вищою - 30\% проти 21\% серед викладачів / дослідників. 
Запитання: Яка допомога надається науково-педагогічним працівникам Вашого ЗВО для сприяння їх участі у міжнародній співпраці?

Табл. (рис.) 2.3.

Bиди допомоги, яка надається НПП для сприяння їх участі у міжнародній діяльності

Управлінці (223 особи)

\begin{tabular}{|c|c|c|}
\hline Види допомоги & Ociб & $\%$ \\
\hline Тренінги & 128 & 57 \\
\hline Консультації & 158 & 71 \\
\hline Курси англійської мови & 146 & 65 \\
\hline Фінансування міжнародної мобільності & 38 & 17 \\
\hline Фінансування міжнародних наукових публікацій & 39 & 17 \\
\hline $\begin{array}{l}\text { Фінансування участі у наукових та освітніх заходах (конференції, семінари тощо) } \\
\text { закордоном }\end{array}$ & 48 & 22 \\
\hline
\end{tabular}

\section{Викладачі / дослідники(633 особи)}

\begin{tabular}{|c|c|c|}
\hline Види допомоги & Осіб & $\%$ \\
\hline Тренінги & 311 & 49 \\
\hline Консультації & 355 & 56 \\
\hline Курси англійської мови & 358 & 57 \\
\hline Фінансування міжнародної мобільності & 60 & 9 \\
\hline Фінансування міжнародних наукових публікацій & 56 & 9 \\
\hline $\begin{array}{l}\text { Фінансування участі у наукових та освітніх заходах (конференції, семінари тощо) } \\
\text { закордоном }\end{array}$ & 74 & 12 \\
\hline
\end{tabular}

\section{Допомога, яка надається НПП для сприяння їх участі у} міжнародній діяльності (\%)

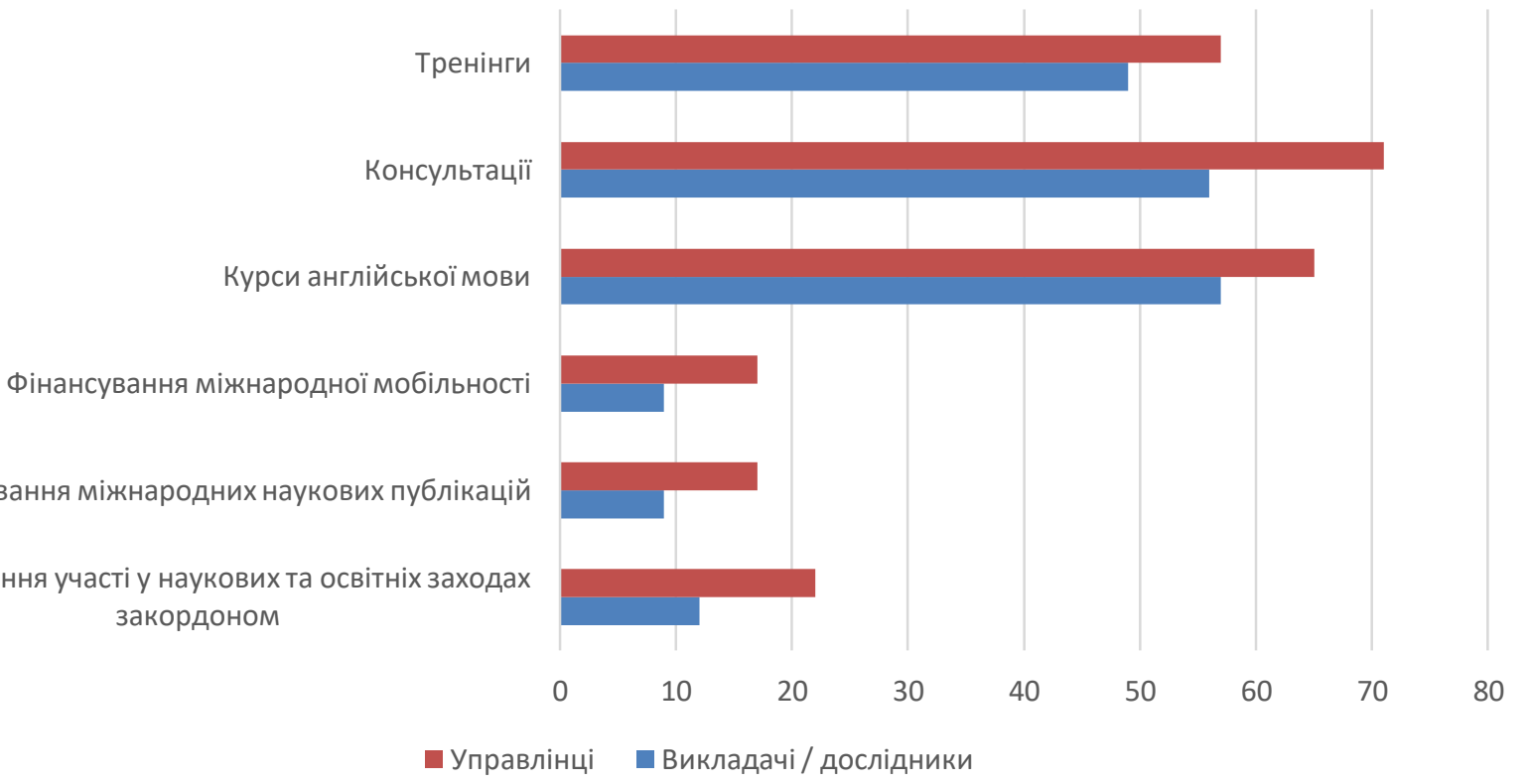

Як випливає з представлених вище даних, бачення управлінців щодо рівня допомоги, яка надається НПП для сприяння їх участі у міжнародній діяльності 3ВО, є «більш оптимістичним» у порівнянні з баченням викладачів / дослідників. При цьому найбільш розповсюдженими на думку і управлінців, і викладачів / дослідників виявилися такі види допомоги:

- тренінги (57\% та 49\% відповідно);

- консультації (71\% та 56\% відповідно); 
- курси англійської мов (65\% та 57\% відповідно).

Результати опитування вказують на низький рівень фінансової підтримки з боку університетів різних видів міжнародної діяльності НПП: цей показник складає 17-22\% в управлінців та 9-12\% у викладачів / дослідників.

Зазначені вище факти дозволяють сформувати такі рекомендації для 3ВО:

- посилити мотивацію викладачів / дослідників щодо їх участі у міжнародній діяльності 3ВО;

- підвищити рівень поінформованості викладачів / дослідників щодо наявних у ЗВО видів допомоги, яка надається НПП для сприяння їх участі у міжнародній діяльності;

- збільшити частку викладачів / дослідників, які отримують допомогу щодо міжнародної діяльності 3ВО; діяльності;

- підвищити частку фінансування, яке спрямовується на підтримку участі НПП у міжнародній

- здійснювати управлінський моніторинг процесів надання допомоги НПП для сприяння їх участі у міжнародній діяльності ЗВО.

Критичною також вбачається потреба посилення зусиль з боку різних стейкхолдерів (на європейському, національному, інституційному та індивідуальному рівнях) для усвідомлення представниками академічної спільноти ЗВО України суттєвого впливу процесів інтернаціоналізації на якість вищої освіти. 
Запитання: Хто здійснює розроблення проектних заявок для участі у програмах міжнародної співпраці у Вашому 3ВО?

Табл. (рис.) 2.4 .

Розробники проектних заявок для участі у програмах міжнародної співпраці

Управлінці (223 особи)

\begin{tabular}{|l|c|c|}
\hline \multicolumn{1}{|c|}{ Розробники проектних заявок } & Ociб & \% \\
\hline Адміністрація 3ВО & 72 & 32 \\
\hline Зарубіжні партнери & 37 & 17 \\
\hline Спеціальний підрозділ (наприклад, відділ міжнародних зв'язків) & 162 & 73 \\
\hline Завідувачі кафедр & 84 & 38 \\
\hline Викладачі / дослідники & 130 & 58 \\
\hline Студенти / аспіранти & 34 & 15 \\
\hline
\end{tabular}

\section{Викладачі / дослідники (633 особи)}

\begin{tabular}{|l|c|c|}
\hline \multicolumn{1}{|c|}{ Розробники проектних заявок } & Ociб & \% \\
\hline Адміністрація 3ВО & 165 & 26 \\
\hline Зарубіжні партнери & 53 & 8 \\
\hline Спеціальний підрозділ (наприклад, відділ міжнародних зв'язків) & 382 & 60 \\
\hline Завідувачі кафедр & 222 & 35 \\
\hline Викладачі / дослідники & 327 & 52 \\
\hline Студенти / аспіранти & 58 & 9 \\
\hline
\end{tabular}

\section{Студенти / аспіранти (220 осіб)}

\begin{tabular}{|l|c|c|}
\hline \multicolumn{1}{|c|}{ Розробники проектних заявок } & Осіб & \% \\
\hline Адміністрація 3ВО & 74 & 34 \\
\hline Зарубіжні партнери & 19 & 9 \\
\hline Спеціальний підрозділ (наприклад, відділ міжнародних зв'язків) & 113 & 51 \\
\hline Завідувачі кафедр & 55 & 25 \\
\hline Викладачі / дослідники & 65 & 30 \\
\hline Студенти / аспіранти & 53 & 24 \\
\hline
\end{tabular}

\section{Розробники проектних заявок для участі у програмах} міжнародної співпраці (\%)

Адміністрація 3ВО

Зарубіжні партнери

Спеціальний підрозділ

Завідувачі кафедр

Викладачі / дослідники

Студенти / аспіранти

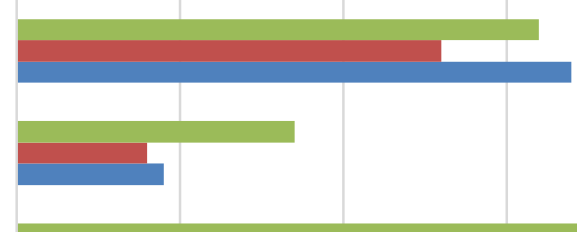

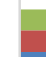

Розробники проектних заявок для участі
у програмах міжнародної співпраці


Як бачимо із даних, певну одностайність респонденти продемонстрували при ідентифікації «найбільш суттєвого розробника» проектних заявок у ЗВО і цим «героєм» очікувано став «спеціальний підрозділ (наприклад, відділ міжнародних зв'язків» (73\%, 60\% та 51\% відповідно).

Щодо оцінки ролі адміністрації ЗВО у процесі розроблення проектних заявок для участі у програмах міжнародної співпраці результати виявилися також співмірними для всіх трьох груп (32\%, 26\% та 34\% відповідно). Невисоко всі три групи оцінили і роль у цьому процесі зарубіжних партнерів (17\%, 8\% та 9\% відповідно).

Фактично однаковою виявилася оцінка управлінцями і викладачами / дослідниками ролі у процесі розроблення проектних заявок для участі у програмах міжнародної співпраці:

- завідувачів кафедр (38\% та 35\% відповідно);

- викладачів / дослідників (58\% та 52\% відповідно).

Як і у попередніх випадках, управлінці демонструють дещо «більш оптимістичне» бачення.

Розійшлися погляди респондентів, приналежних до різних категоріальних груп, в оцінці ролі студентів у процесі розроблення проектних заявок для участі у програмах міжнародної співпраці:

- Управлінці та викладачі / дослідники оцінили цю роль достатньо низько (15\% та 9\% відповідно).

- У той же час, здобувачі вищої освіти оцінили роль студентів у процесі розроблення проектних заявок для участі у програмах міжнародної співпраці значно вище - 24 \%.

Представлені вище дані та висновки дозволяють надати певні рекомендації для 3ВО, а саме:

- Більш активно співпрацювати із зарубіжними партнерами (наприклад, шляхом організації обмінів і спільних заходів, підготовки спільних доповідей і публікацій) для «провокування» їх до виконання ролі «розробників проектних заявок».

- Підтримувати та розвивати потенціал представників різних груп академічної спільноти університету (від студента до управлінця) через розбудову / диверсифікацію у зВо системи (комплексу заходів, механізмів, інструментів) мотивації та допомоги для ефективної реалізації ролі розробника проектних заявок.

- Покращити комунікацію та співпрацю між управлінцями, викладачами / дослідниками та студентами / аспірантами ЗВО у процесі розроблення проектних заявок для участі у програмах міжнародної співпраці.

У цілому по розділу окремо зазначимо, що академічний персонал позитивно оцінює стан інтернаціоналізації у ЗВО України, хоча викладачі / дослідники відзначають досягнення за конкретними напрямами більш стримано, ніж здобувачі вищої освіти та управлінці.

Надані відповіді свідчать також про те, що офіційні вимоги щодо інтернаціоналізації та публікаційної активності НПП недостатньо підкріплені фінансуванням з боку зВО. Можна стверджувати, що реалізація цих вимог здійснюється переважно за рахунок витрат академічного персоналу або коштів донорських організацій / міжнародних проектів. 


\title{
Розділ II. Наукометричні показники, ранжування та наукова ідентифікація як фактори інтернаціоналізації вищої освіти і науки у контексті стійкого розвитку
}

\author{
Віктор Зінченко, \\ доктор філософських наук, \\ старший науковий співробітник, \\ завідувач відділу інтернаціоналізації вищої освіти \\ Інституту вищої освіти НАПН України, \\ https://orcid.org/0000-0001-9729-6861
}

Анотація. Одна з провідних цілей наукометричних показників та даних у контексті інтернаціоналізації інституцій та установ вищої освіти і науки України - це включення до міннародної, глобальної науково-освітньої системи якомога більшої кількості релевантних наукових спільнот, колективів науковців, дослідників та ї наукових праць, розробок, інновацій і рейтингування їх за певними об'єктивними показниками.

Наукометрична система і їі різноманітні складові, зокрема, так звані «бази даних» - це аналітична, порівняльно-ранжувальна («індексувально-рейтингова»), бібліографічна і реферативна система науково-дослідних даних, інструмент для відстеження иитованості наукових публікацій та інших результатів наукової і науково-дослідницької діяльності. Наукометрична база даних - це також $і$ пошукова система, яка формує статистику, що характеризує стан і динаміку показників затребуваності, активності та індексів впливу діяльності окремих вчених і дослідницьких організацій.

Виникнення наукометричних баз (систем, платформ) є природнім явищем у розвитку суспільства як спроба виміряти те, що з одного боку є абстрактним, а з іншого - в результаті глибокого аналізу характеризується певними кількісними ознаками. Наукові дослідження зумовлюють прискорений розвиток технологій, отже на певному етапі виникла необхідність оцінити, тобто виміряти вагомість науково-дослідницького внеску вченого для розвитку певної галузі досліджень. Оскільки ию потребу відчули в різних країнах з відносно невеликою різницею у часі, були винайдені і розроблені різні наукометричні технології.

Щоб підвищити наукометричні показники, за якими проводяться кількісні оцінки і порівняльний аналіз наукової активності авторів та наукових установ, потрібно публікуватися у закордонних $i$ вітчизняних журналах, що входять до відомих наукометричних систем/баз, реєструватися й створювати свій авторський профіль в міжнародних наукометричних базах. 
Інтернаціональні показники науково-дослідницької діяльності та ідентифікатори вченого

Щоб виявити, позиціонувати та підвищити показники, за якими проводяться якісні та кількісні оцінки і порівняльний аналіз наукової активності авторів та наукових установ, потрібно публікуватися у закордонних і вітчизняних журналах, що входять до відомих наукометричних систем, реєструватися й створювати свій авторський профіль в міжнародних наукометричних системах.

Наукометричні показники - це індекси активності публікації авторів або організацій, значущості публікацій залежно від наукової ваги журналу і т. ін. Це інструмент оцінки значущості якості наукової роботи, впливовості науковця, наукової періодики, можливість залучення кращих науковців до співпраці у певних сферах чи за певною тематикою, формування наукового іміджу вченого та його затребуваності в обраній науковій сфері. Використовуються для оцінки стану і перспективності науково-дослідної діяльності авторів та організацій, їх порівняння і ранжування у різних рейтингах.

Метою ідентифікаторів вченого є поєднати науковців та їхні різноманітні науково-дослідницькі та інноваційні напрацювання. Для цього вчений повинен створити профілі та зареєструватися в ORCID, Google ScholarlD, ResearcherID, а також бажано у соціальних наукометричних мережах Linkedln, Researchgate, Academia.edu тощо. Якщо у вченого є публікації, котрі опубліковані у наукових виданнях, які входять до науко метричної реферативної бази Scopus, - створюється відповідний профіль ScopusID.

Індекс цитування наукових статей - база даних наукових публікацій, що індексує посилання, вказані у пристатейних списках цих публікацій і що надає кількісні показники цих посилань. Розрахунок показників цитованості в кожному конкретному ресурсі здійснюється на основі інформації (джерел), що міститься саме в даному ресурсі, тому показники цитованості одного і того ж автора в різних ресурсах можуть розрізнятися. Індекс цитування - це прийнята в науковому світі міра значущості наукової роботи якого-небудь ученого або наукового колективу. Величина індексу цитування визначається кількістю посилань на публікацію або прізвище автора в інших джерелах. Однак для точного визначення значущості наукових праць важливо не тільки кількість посилань на них, але й якість цих посилань. Індекс цитування показує, скільки разів статті, написані даним автором, були процитовані в роботах інших авторів. Як правило, учений має великий індекс цитування, якщо його роботи були опубліковані в журналах з високим імпакт-фактором.

Імпакт-фактор (або Коефіцієнт впливовості) - формальний чисельний показник інформаційної значимості наукового журналу. Він показує, скільки разів у середньому цитується кожна опублікована в журналі стаття протягом наступних років після виходу публікації. Коефіцієнт впливовості обчислюється за 3 роки та 5 років. Його можна розглядати як усереднене співвідношення кількості цитувань статей в журналі протягом поточного року, до загальної кількості статей надрукованих в цьому журналі за попередні два роки. Для нових журналів імпакт-фактор іноді розраховується тільки для дворічних періодів. Імпакт-фактор є мірою, що визначає частоту, з якою цитується середньоцитована стаття журналу. Імпакт-фактор відображає якість робіт, що публікуються в журналах, через оцінку продуктивності і цитованості, тобто, наукової популярності журналу. Імпакт-фактор - це й важлива характеристика наукових журналів, наукових організацій та спільнот.

Індекс onepamuвності (immediacy index) - розрахунковий показник, який показує, наскільки швидко стають відомі в науковому світі статті, опубліковані в журналі. Наприклад, індекс оперативності певного року обчислюється як відношення числа отриманих журналом у цьому році посилань на статті, опубліковані в ньому у цей рік, до сумарного числа статей, що вийшли в журналі у даному році.

Індекс Гірша (h-індекс) - кількісна характеристика вченого, заснована на кількості його публікацій і кількості цитувань цих публікацій. Тобто вчений має індекс h, якщо h з його N статей цитуються як мінімум $\mathrm{h}$ раз кожна. Наприклад, учений має індекс Гірша рівний 5, якщо ним було опубліковано щонайменше 5 робіт, кожна з яких була процитована 5 і більше разів. Тобто, якщо учений опублікував 10 статей, при цьому 9 цитувалися по одному разу, а одна - сто разів, його індекс Гірша все одно буде одиниця. Тому що немає двох статей, які отримали 6 не менше двох посилань. Показник, запропонований в 2005 р. американськими фізиком Г. Гіршем з університету Сан-Дієго, Каліфорнія. Індекс добре працює лише при порівнянні вчених, що працюють в одній галузі досліджень, оскільки традиції, пов'язані з цитуванням, відрізняються в різних галузях науки (наприклад, в біології та медицині h-індекс набагато вище, ніж у фізиці). Високий показник Гірша означає, що у вченого багато статей, книг, розробок, багато з яких активно цитувалися. Індекс Гірша інформує про ступінь корисності публікацій (цитування, використання, впровадження тощо) для наукової спільноти на 1) міжнародному і 2) національному рівнях. Цей індекс вказує на ефективність наукової роботи в університеті, установі, організації. колективі. 
І-індекс - індекс, що відображає публікаційну активність науковця, наукової організації, розраховується на основі бібліометричних показників

ID GoogleScholar (Google Академія) - вільнодоступна міжнародна наукометрична та індексувальнорейтингова і пошукова система, яка індексує повнотекстові наукові публікації усіх форматів, 3 усіх дослідницьких напрямів і дисциплін. Google Scholar індексує більшість електронних ресурсів (бази, бібліотеки, репозитарії, сховища тощо), рецензованих онлайн-журналів світу і найбільших наукових видавництв. Google Академія - глобальна наукометрична пошукова та міжнародна індексувальна система і бібліометрична база даних, яка індексує метадані наукових публікацій з усіх галузей знання, опубліковані у різних форматах. Індекс Google Академії містить у собі більшість рецензованих журналів Європи та Америки найбільших наукових видавництв. Цей продукт має інструментарій для відслідковування наукової цитованості проіндексованих публікацій. Хоча компанія Google офіційно не розголошує обсяг індексу Google Академії, фахівцями цей обсяг оцінюється приблизно у 160 млн документів.

Після реєстрації та створення профілю автора - починає здійснюватися пошук та індексація авторських онлайн-джерел, система обчислює індекс Гірша за публікаціями автора, а також відображає кількість цитувань кожної статті.

Бібліометрика української науки - призначена для надання суспільству цілісної картини стану вітчизняного наукового середовища. Інформаційні ресурси системи формуються шляхом опрацювання: створених науковцями на платформі Google Scholar бібліометричних профілів, бібліометричних показників систем Scopus, Web of Science, Ranking Web of Research Centers, інших систем та їхніх індексів наукового цитування. Оновлення інформації про значення індексів Гірша в бібліометричних профілях учених здійснюється щомісячно, значення інших показників актуалізуються щоквартально.

Science Index - включає публікації з понад 46000 наукових журналів. Профіль в Science Index, яка позиціонується як інформаційно-аналітична система, що акумулює понад 18,6 мільйонів публікацій, дозволяє отримати багатоманітне індексування матеріалів автора, а також інформацію про цитування цих публікацій.

Publish or Perish - $€$ безкоштовною науковою пошуковою системою, яка разроблена професором у галузі міжнародного менеджменту Anne-Wil Harzing за підтримки компанії Google. Програму Publish or Perish треба завантажити з Інтернету та виконати інсталяцію. Ця пошукова система дозволяє виконувати пошук публікацій за прізвищем автора. Результатом роботи системи є повний комплект наукометричних показників по публікаціях автора - від індекса Гірша до числа співавторів у знайдених статтях. Крім того можна визначити імпакт-індекси цитування для наукових журналів - за числом цитувань статей певного наукового видання обчислюється індекс Гірша цього видання. Результатом роботи системи як для окремого автора, так і для журналу $є$ повний комплект наукометричних показників по публікаціях - від індекса Гірша до числа співавторів у знайдених статтях.

ORCID (Open Researcher and Contributor ID) - глобальний науковий проект єдиного, міжнародного реєстру вчених. Це відкрита база даних вчених та реєстр унікальних ідентифікаторів учених і разом з тим відповідний метод, що пов'язує дослідницьку діяльність з цими ідентифікаторами. ORCID унікальний завдяки своїй незалежності від наукових дисциплін і національних меж, а також взамодією з іншими системами ідентифікації. Основна мета створення ORCID - вирішити проблему ідентифікації вчених з однаковими іменами і прізвищами. ORCID забезпечує наступні функції: отримання унікального ідентифікатора і ведення відповідного облікового запису про дослідницьку діяльність; програмне забезпечення для міжсистемної комунікації. Обліковий запис ORCID включає інформацію про ім'я вченого, його електронну адресу, назву організації і його дослідницької діяльності. ORCID враховує необхідність контролю за розповсюдженням цих даних і надає відповідні інструменти для управління рівнем приватності даних.

ResearcherID - міждисциплінарний реєстр унікальних ідентифікаторів вчених та результатів їхніх досліджень. Передбачає створення авторського профілю на платформі науко метричної системи Web of Science. Це ресурс, який дозволяє: створювати профіль вченого, формувати список власних публікацій, здійснювати пошук вчених, або груп авторів за темою досліджень, створювати запрошення до співпраці, переглядати бібліометричні показники за WoS, асоціювати свій профіль з Orcid. Досягається аналіз та показники про результативність науковця за Web of Science та оцінка співпраці і цитувань вченого.

Publons - спеціалізована міжнародна система для вчених світу, пов'язана з ResearcherID, метою якої $\epsilon$ відстеження, перевірка та демонстрації своїх публікацій і розробок через Scholarly peer review, рецензування наукових здобутків інших науковців та редакційних матеріалів для академічних журналів, рецензування і оцінки науково-дослідницької ефективності. Publons інтегрована з науково-ідентифікаційними службами, зокрема, такими, як ORCID та Altmetric, наукометричними системами Web of Science i Scopus тощо, має 
партнерські відносини з великими міжнародними науковими видавцями, серед яких Springer, Elsevier, Taylor and Francis, Oxford University Press, BMJ, SAGE, Wiley та ін.

Researchgate.net - $\epsilon$ складовою міжнародної системи академічних ресурсів. Це безкоштовна соціальна мережа і засіб співпраці учених всіх наукових дисциплін, котра передбачає пошук фахових дослідників, координацію між ними та об'єднання для спільної науково-дослідницької діяльності. Також передбачає обмін файлами, спільне користування базою публікацій, форуми, методологічні дискусії, групи тощо. Члени спільноти можуть створювати свій персональний блог у межах мережі. Серед інших засобів, ResearchGate розвинув пошуковий механізм, який здійснює пошук по внутрішніх ресурсах і основних зовнішніх наукометричних базах даних та електронних ресурсах тощо, для знаходження наукових статей та інших наукових матеріалів. Здійснює ранжування наукових показників вченого згідно з визначенням відповідних показників h-індексу.

Linkedln - є складовою міжнародної системи академічних ресурсів. Це - соціальна мережа для пошуку та встановлення наукових і ділових контактів. У Linkedln зареєстровано понад 400 мільйонів користувачів, що представляють 150 галузей бізнесу з 200 країн

Academia.edu - є складовою міжнародної системи академічних ресурсів. Академія $\epsilon$ однією 3 найпопулярніших наукових соціальних мереж з 46,035,250 учасниками. Дослідники можуть завантажувати свої документи та спілкуватися з іншими вченими. За даними веб-сайту Academia, «Academia - це простий засіб та спосіб обмінюватися документами з мільйонами людей у всьому світі безкоштовно».

Ті науковці, котрі здійснюють суспільствознавчі, економічні та управлінські дослідження і розробки включають результати та отримують Short ID у спеціалізованих взаємоінтегрованих міжнародних наукометрично-ранжувальних системах IDEAS/RePEc.

Наявність в науково-освітніх організаціях вчених, які мають високий індекс цитування, говорить про високу ефективність та результативності діяльності закладу в цілому. 
Наукометрична система/база даних - це аналітична, порівняльно-ранжувальна («індексувальнорейтингова»), бібліографічна і реферативна база даних, інструмент для відстеження цитованості наукових публікацій та інших результатів наукової і науково-дослідницької діяльності. Наукометрична база даних - це також пошукова система, яка формує статистику, що характеризує стан і динаміку показників затребуваності, активності та індексів впливу діяльності окремих вчених і дослідницьких організацій.

Їхня історія починається у 70-х роках XIX століття, коли вперше з'явилися два індекси наукового цитування - індекс юридичних документів Shepard's Citations у 1873 році та індекс наукових публікацій з медицини Index Medicus у 1879. 3 розвитком Інтернет природно з'явилися інші - електронні мережеві наукометричні бази.

Згідно із наказів та постанов Міністерства освіти і науки серед вимог для здобуття наукового ступеня, отримання обсягу державного замовлення для ЗВО тощо передбачено обов'язкові публікації в іноземних виданнях та виданнях України, - котрі внесені до реєстру міжнародних наукометричних баз. Спільним для всіх $€$ :

1) одна з провідних цілей - включити до бази якомога більше релевантних науковців та їх наукових праць та рейтингувати їх за певними показниками;

2) місце - інтернет;

3) цільова аудиторія - переважно науковці;

4) формат пошукової платформи;

5) чітко визначені вимоги до реєстрації та розміщення наукових публікацій, а також - і до користування ними (огляду, цитування).

3 огляду на різноманіття наукометричних підходів, можна покласти в основу класифікації такі характеристики:

А - за функціональним типом (позиціюванням) - електронні бібліотеки, платформи, бібліографічні бази, системи, репозитарії тощо;

В - за кількісним показником наявних 1) науковців; 2) публікацій; 3) співвідношенням науковців і публікацій - великі (гранд-системи), середні (медіум-системи), малі системи;

C - за якісними показниками - за кількістю застосованих індексів цитування та інших сервісів advanced, medium, basic;

D - за кількістю залучених дисциплін - мультидисциплінарні та галузеві;

E - за відкритістю доступу - комерційні та відкриті.

\section{Класифікація міжнародних систем цитування (наукометричних систем та бібліографічних баз):}

1) універсальні (транснаукові, міждисциплінарні) реферативні бази - Web of Science, Scopus, EBSCO, DOAJ, OCLC WorldCat, MIAR, Genamics JournalSeek, Springer, Open Academic Journals Index, PИНЦ/RSCI, Academic Resource Index (Research Bib), Directory of Research Journals Indexing, Index Copernicus, Global Impact Factor, Genamics JournalSeek тощо.

2) спеціалізовані (галузеві) - Astrophysics, ERIH PLUS, PubMed, MathSciNet, Mathematics, Chemical Abstracts, Agris, GeoRef тощо.

3) наукометричні електронні бібліотеки/репозитарії/каталоги індексації міжнародних наукових журналів та матеріалів - Ulrich's Periodicals Directory, ROAR (Registry of Open Access Repositories), Directory Indexing of International Research Journals, International Scientific Indexing, Directory of Research Journals Indexing, CiteFactor, Киберленинка, Universal Impact Factor, NewJour, International Scientific Indexing та ін.

4) міжнародні системи академічних ресурсів/соціальні наукові і наукометричні мережі ResearcherGate, SciPeople, Mendeley, LinkedIn, Academia.edu тощо.

5) Google Scholar (Google Академія) - вільнодоступна міжнародна наукометрична та індексувальнорейтингова і пошукова система, яка індексує повнотекстові наукові публікації усіх форматів, 3 усіх дослідницьких напрямів і дисциплін. Google Scholar індексує більшість електронних ресурсів (бази, бібліотеки, репозитарії, сховища тощо), рецензованих онлайн-журналів світу і найбільших наукових видавництв. Google Академія - глобальна наукометрична пошукова та міжнародна індексувальна система і бібліометрична база даних, яка індексує метадані наукових публікацій з усіх галузей знання, опубліковані у 
різних форматах. Індекс Google Академії містить у собі більшість рецензованих журналів Європи та Америки найбільших наукових видавництв. Цей продукт має інструментарій для відслідковування наукової цитованості проіндексованих публікацій. Хоча компанія Google офіційно не розголошує обсяг індексу Google Академії, фахівцями цей обсяг оцінюється приблизно у 160 млн документів.

Існує велика кількість міжнародних наукометричних баз, але наразі найавторитетнішими з них, індекси яких визнаються в усьому світі, $є$ :

Web of Science (WOS, попередня назва ISI Web of Knowledge) - це наукометрична та індексувальна система і пошукова платформа, що об'єднує електронні реферативні бази даних публікацій у наукових журналах і патентів, зокрема бази, що враховують взаємне цитування публікацій. Ця база даних статей та інших наукових матеріалів, початково була створена у Філадельфійському інституту наукової інформації (Thomson Reuter Master Journal List), що дозволяє здійснювати пошук серед десятків тисяч журналів і сотень тисяч матеріалів конференцій і включає індекси/бази/платформи - Science Citation Index Expanded (природничі науки), Social Sciences Citation Index (суспільні науки), Arts and Humanities Citation Index (мистецтво та гуманітарні науки); з 2015 р. з'явилася четверта - ESCI (Emerging Sourrce Citation Index) - індекс нових наукометричних видань. Ці ресурси не завжди містять повних текстів статей, однак включають посилання на повні тексти в першоджерелах і списки всіх бібліографічних посилань, що зустрічаються в кожній публікації. Імпакт-фактор будь-якого журналу, який включено до бази Web of Science, можна дізнатися безпосередньо на сайті кожного журналу. Відповідно визначають показники цитування у SCIE, SSIE, AHCI (SCIE - показник цитування природничих та технічних наук; SSIE - показник цитування суспільних наук; $\mathrm{AHCl}$ - показник цитування по мистецтву та гуманітарним наукам).

EBSCO - один з найкрупніших наукометрично-індексувальний агрегатор наукових ресурсів. Це провідний постачальник електронних сервісів та баз даних на ринку інформаційних послуг, який надає понад 200 наукових, технічних та медичних баз для різноманітних груп користувачів. База даних EBSCO містить понад 30.000 повнотекстових журналів, книг, брошур, газет, довідників та аналітичних оглядів й архівів. Це доступні через веб-інтерфейс бази даних наукової інформації з галузей медицини, фізики, хімії, економіки, соціогуманітарних та інших наук, що періодично оновлюються. EBSCOhost надає можливість пошуку повнотекстових, рецензованих статей наукових журналів, довідників та інших публікацій з різних наукових дисциплін. Включає в себе як бази даних доступні на умовах передплати, так і бази даних, які знаходяться у відкритому доступі.

Scopus (SciVerse Scopus) - мультидисциплінарна наукометрична, бібліографічна, реферативна база даних та інструмент для відстеження цитованості статей, опублікованих у наукових виданнях, створена видавничою корпорацією Elsevier. $€$ однією зі складових інтегрованого науково-інформаційного середовища SciVerse. Індексує понад десятки тисяч назв наукових видань з технічних, медичних та гуманітарних наук понад 5000 видавців. База даних індексує наукові журнали, матеріали конференцій та серіальні книжкові видання. Розробником та власником SciVerse Scopus $€$ видавнича корпорація Elsevier. Однією з основних функцій цієї бази даних є вбудована у пошукову систему інформація про цитування.

Scopus охоплює понад 20 тис. наукових журналів (з технічних, медичних та деяких гуманітарних наук) від 5 тис. наукових видавництв світу, включаючи близько 250 журналів з кириличними шрифтами, 13 млн патентів США, Європи і Японії, матеріали наукових конференцій. Scopus - одна з найбільших у світі реферативна база даних і науко метрична платформа. Наукометричний апарат бази даних забезпечує облік публікацій науковців і установ, у яких вони працюють, та статистику їх цитованості. Scopus надає гіперпосилання на повні тексти матеріалів. База даних доступна за умов підписки через веб-інтерфейс. Вона забезпечує якісну підтримку в пошуку наукових публікацій і пропонує посилання на всі існуючі цитати 3 обширного обсягу доступних статей. Scopus охоплює велику кількість наукових журналів від різноманітних наукових видавництв світу, включаючи патенти США, Європи і Японії та матеріали наукових конференцій. Scopus індексує назви наукових видань з технічних, медичних та гуманітарних наук. Розробником та власником SciVerse Scopus $€$ видавнича корпорація Elsevier. Вона $€$ комерційною БД і повна її версія доступна тільки на умовах передплати через веб-інтерфейс. Однак існує можливість перегляду ресурсів БД Scopus в обмеженому режимі Author preview (доступно: кількість представлених у БД статей автора, h-index, кількість цитувань, affiliation history).

WorldCat - одна з найбільших у світі бібліографічна база даних, яка налічує понад 240 млн записів всіх видів творів на 470 мовах світу. База створюється спільними зусиллями більш ніж 72 тис. бібліотек з 170 країн світу в рамках організації Online Computer Library Center. 
Directory of Open Access Journals (DOAJ) - це наукометрична база та, водночас, сервіс, що надає доступ жүрналам, які контролюють якість публікацій з відкритим доступом. Каталог, індексуючи журнали, прагне бути всеосяжним і охоплювати всі наукові та академічні журнали відкритого доступу, які використовують відповідні системи контролю якості. це також онлайн-каталог, який індексує якісні рецензовані наукові журнали відкритого доступу з усіх галузей фізико-математичних, технічних, медико-біологічних та соціогуманітарних наук. Індекс каталогу складають більше 2 млн статей з більш ніж 10,000 журналів відкритого доступу від видавців з 134 країн світу. Згідно визначення проекту, під журналом відкритого доступу розуміється науковий журнал, який дотримується високих видавничих стандартів якості, практикує наукове рецензування або іншу форму контролю та має бізнес-модель, яка не передбачає плати учених або їхніх установ за доступ до опублікованого змісту. 


\section{Проблемні аспекти розвитку наукометричних систем у освітньо-науковому просторі розвинених та транзитивних країн та перспективи посилення їхньої ефективності і відкритості як фактор стійкого розвитку}

1. У Рішенні Комітету з питань науки і освіти Верховної ради України від 18.03.2015р. (Протокол №8): "Вимога щодо публікування у виданнях, що індексуються у провідних міжнародних наукометричних базах Web of Science ma (або) Scopus, не враховує галузеву специфіку знань. Вищезазначені вимоги вимагають суттєвого фінансового забезпечення».

Видавничий концерн Elsevier та його наукометричний підрозділ Scopus пропонує два види поширення статті та інших наукових результатів: традиційна передплата (Subscription) і плата за публікацію статті (Article Processing Charge) у тому випадку, якщо автор хоче, щоб його робота знаходилася у відкритому доступі. Ціни, представлені на сайті видавництва, варіюються від 500 до 5000 доларів США. Статті, оплачувані по даній моделі, публікуються на платформі ScienceDirect.

Класифікаційна система Scopus включає:

1) Природничі та технічні науки (32\%).

2) Медичні науки (31\%).

3) Біологічні, аграрні, нейрофізіологічні науки (20\%).

4) Соціогуманітарні науки (лише 17\%).

2. Також зазначимо, що комерційний характер та відповідні цілі діяльності цих баз (у більшій мірі Scopus, у меншій - Web of Science) не дозволяють у повній мірі забезпечити

1) вільний (безоплатний) доступ навіть для ознайомлення до матеріалів, розміщених в них, що у свою чергу

2) не може забезпечити ефективного та всеохоплюючого цитування, а, як наслідок і - ранжування, індексування як цих матеріалів, так і їхніх авторів.

Наведемо лише один приклад - найбільша у світі міжнародна наукометрична та бібліометрична пошукова система Google Scholar, відповідно до якої і формується найбільш повний наукометричний профіль науковця - незалежно від його континентальної, мовної, національної, державної та іншої приналежності індекс Гірша ( $h$-індекс) - не в змозі здійснювати ранжування (цитованості, затребуваності, використання тощо) матеріалів, розміщених у Scopus та Web of Science.

Відзначимо, що керівництво WoS, починаючи з 2015-2016 pp., розуміючи дану проблему та прагнучи до наукової відкритості та глобального поширення, здійснює активну інтеграцію з національними та континентально-регіональними наукометричними базами, формуючи спільні наукометричні платформи для розміщення найкращих матеріалів з них (i не обов'язково англомовних) з наступним перенесенням їх до т.зв. «ядра WoS».

На жаль, мусимо констатувати, що база Scopus не здійснює подібної стратегії, а навпаки, посилює політику наукометричної «закритості» та отримання комерційної вигоди навіть за оглядове ознайомлення 3 будь-яким матеріалом. Звичайно, за цих умов, доступ, використання у науково-дослідній діяльності, цитування тощо матеріалів, розміщених у Scopus, $є$ доступним лише окремій групі (якісно фінансованих) установ, організацій, науковців. А це у жодній мірі не сприяє об'єктивному відображенню індексу цитованості і сформованому на його основі індексу, рейтингу науковця.

3. Все більше представників наукової спільноти, наукові, освітні заклади, установи, організації розвинених країн ЄC, ОЕСР відмовляються внаслідок цього від співробітництва зі Scopus.

Щоб наблизитися до мети, встановленої урядами країн ЄC, у стратегії загальної практики публікаційної політики наукових програм ЄС (повний відкритий доступ до наукових досліджень), Швеція та інші держави відмовилася продовжувати будь-які угоди з цією корпорацією та ї̈ структурами,

Також провідні представники науки Європи та США, починаючи ще з 2012 р., сформували спільноту та здійснюють розсилку інформації для світового наукового середовища про те, що вчені-фізики та вчені 3 технічних наук на своїй нараді в GSI Дармштадт 25 травня 2012 року прийняли рішення попросити всіх представників даних наук приєднатися до ініціативи групи провідних вчених-математиків з бойкоту «Elsevier» та приєднатися до декларації: «httр://thecostofknowledge.com/» The cost of Knowledge (Bapmicmь знань)», яка спрямована на реалізацію відкритого доступу для користувачів-дослідників та читачів наукових статей і проти необгрунтованих платежів від авторів або їх установ. Рух просить окремих вчених утриматися від публікації 
статей у журналах Elsevier (й, відповідно, у базі Scopus). Цей рух на світовому рівні вже досяг помітних успіхів - на даний час десятки тисяч провідних вчених розвинених країн приєдналися до акції. До руху приєдналися й вчені-медики, у тому числі і нобелівські лауреати.

Багато країн-членів Євросоюзу налаштовані проти Elsevier та його наукометричних продуктів через його закритість у веденні бізнесу, високі й дедалі зростаючі ціни та потенційно небезпечний масштаб комерційного видавця. Низка країн вдаються до бойкоту Elsevier та відмови від їхніх журналів та продуктів на кшталт Scopus.

Дослідницькі інститути Швеції та Німеччини заявили, що відмовляються від будь-яких передплат у Elsevier через побоювання щодо стабільності, нечесний механізм ціноутворення та загальну відсутність моральних цінностей (наприклад, метричні дані Elsevier у вигляді CiteScore, що є показником впливу журналів, які конкурують за імпакт-фактор, базований на базі цитувань зі Scopus - $є$ не доброчесними: як свідчить неупереджений аналіз, періодика, що видається конкурентами Elsevier, отримує на 40\% нижчі показники, а видання Elsevier отримують на 25\% вищі показники з використанням CiteScore, ніж інших систем визначення імпакт-фактору журналів (https://www.insidehighered.com/news/2016/12/14/exploring-citescoreelseviers-new-journal-impact-metrics).

Також, із-за постійного підвищення ціни за користування сервісами доступу Scopus та за передплату на журнали власника Scopus - видавничого концерну «Elsevier» - лише у США від його послуг відмовилися: найбільша у світі Бібліотека Конгресу, Гарвардський університет, Массачусетський технологічний інститут, Корнельський університет, Університет штату Флорида, Університет штату Північна Кароліна, Каліфорнійський університет та ін., провідні університети Західної Європи, значна кількість Академій наук цих держав (зокрема, Товариство Макса Планка [Академія наук ФРH], Асоціації університетів Нідерландів (VSNU), консорціуму університетів та інститутів Німеччини DEAL і багато інших закладів і установ розвинутих країн.

4. Збільшення індексу Гірша, квартилів публікацій та імпакт-факторів чиновники оголошують мало не панацеєю науки і освіти в Україні. Тим часом, в науці важливі результати, а не рейтинги.

Ще у 2012 р. у Сан-Франціско була прийнята Декларація по оцінці науково-дослідницької роботи (DORA - https://sfdora.org/), головною рекомендацією якої: «Не використовувати метрики, що базуються на журналах - зокрема, такі, як імпакт-фактори - в якості сурогатного виміру оцінки дослідницьких статей індивідуального вченого, для судження про його внесок у науку або при прийомі на роботу, просуванні по службі чи при прийнятті рішень про фінансування», оскільки це є спробами підмінити наукові критерії оцінки досліджень бібліометрією. Декларацію підписали десятки наукових організацій та установ, багато редакторів наукових журналів, сотні вчених. Серед перших - Американська асоціація розвитку науки, Європейське математичне товариство, Медичний інститут Говарда Гьюза, Чеська академія наук, Американське товариство нафтохіміків, Американське агрономічний товариство, Асоціація австралійських медичних дослідницьких інститутів, Європейське товариство історії науки та ін.

Головний редактор провідного світового наукового журналу «Science» Брюс Альбертс, видатний біохімік, президент Національної академії США з 1995 по 2009 рр. і одного із співавторів DORA, у зв'язку з цим опублікував статтю «Про викривлення, пов'язаних з імпакт-фактором». Головна думка статті - «манія імпакт-факторів є безглуздою» (https://science.sciencemag.org/content/340/6134/787.full).

Стосовно шкідливості переоцінки бібліометричних показників та застосування т.зв. «індексів», «квартилів» та «імпакт-фрактору» (які використовуються Scopus та Web of Science) як критеріїв «якісності» наукових результатів і публікацій, категорично ще у 2017 р. спільно виступили проти Академія наук Франції, Леопольдіна (Національна Академія наук Німеччини), Королівське товариство (Академія наук Великої Британії), відзначивши, що деякі експертні спільноти занадто покладаються на бібліометричні показники при оцінці значущості робіт, що може призводити до поверхневого, спрощеного і ненадійного оцінювання наукових результатів. Таким чином, переважне використання бібліометричних показників при оцінці наукових досліджень стало причиною серйозної занепокоєності. Особливе занепокоєння викликає повсюдне використання імпакт-факторів журналів, які скоріше $€$ оцінкою самого журналу, ніж оцінкою наукової значущості опублікованих у ньому статей.

Також, надмірна довіра до індексів цитованості як до показників якості може стати причиною формування груп дослідників, які «накручують» показники один одного за допомогою перехресного цитування (іншими словами, з'являються т.зв. «клуби любителів цитування»). Таким чином, важливо сконцентруватися на методах, цілях і результатах наукової діяльності, які сприяють просуванню якісних і 
інноваційних досліджень у різних галузях знання (https://royalsociety.org/topics-policy/publications/2017/royalsociety-leopoldina-and-academie-des-sciences-call-for-more-support-for-research-evaluators/).

5. Жорсткі вимоги зарахування для присудження наукових ступенів та присвоєння вчених звань публікацій виключно у виданнях, присутніх у базах WoS, а тим більше, Scopus, порушують також принципи академічної свободи і академічної доброчесності. Вони обмежують вибір науковцями спеціалізованих жүрналів для публікації результатів своїх досліджень із врахуванням дотичності спеціалізованого журналу до проблематики своїх наукових досліджень, а також у силу складності виконання цих вимог можуть стимулювати появу так званих «наукових млинів», які пропонують за гроші підготувати для науковця статтю для публікації у журналах, індексованих у базах WoS i Scopus, і забезпечити супровід такої публікації. Пропозиції щодо надання таких сумнівних послуг уже надходять представникам наукової спільноти і вже створені «консорціуми», які надають такі послуги на платній основі.

6. Фактична жорстка вимога друкувати значну своїх статей іноземною (переважно англійською) мовою в іноземних журналах, що індексуються у закритих базах даних, може призвести до гальмування розвитку національної науки, національних наукових шкіл, національних наукових журналів, національної наукової мови. Високоякісна наукова статя, якщо вона становить інтерес для міжнародної спільноти, може бути перекладена іноземною (англійською) мовою і таким чином стати доступною для науковців усього світу.

7. Головним пріоритетом розвитку України визначається інтеграція з Європейським Союзом (у тому числі - й у застосуванні дослідницьких, наукових та публікаційних підходів).

У зв'язку з цим, необхідно враховувати, що з 1-го січня 2020 року у науково-дослідницькому просторі ЄС впроваджується т.зв. «План S».

«Plan S» - це ініціатива, спрямована на консолідацію зусиль для якнайшвидшого переходу до таких публикаційних моделей, які надають повний, негайний відкритий і безкоштовний доступ до результатів наукових досліджень.

Ініціатива була запущена 4 вересня 2018 року низкою великих національних фондів з дванадцяти європейських країн, а також Європейською дослідницькою радою. Ці агентства сформували консорціум під назвою »cOAlition S» (у назві: S - science - наука, OA - open access - відкритий доступ, coalition - об'єднання).

Основна мета «cOAlition S» полягає в тому, що після 1 січня 2020 року результати наукових досліджень повинні публікуватися у відповідних журналах відкритого доступу або на відповідних наукометричних платформах відкритого доступу.

За умовами «Плану S», провідні європейські наукові організації вимагатимуть публікувати результати досліджень в журналах з негайним відкритим доступом і по ліцензії, що надає право на вільне безкоштовне й повторне використання та поширення матеріалу.

«Гібридна модель» публікації не допускається, оскільки не відповідає вищезазначеним принципам («Гібридна модель» - передбачає 1. повну або часткову оплату авторами за публікації та 2. оплату за ії подальший перегляд чи завантаження науковцями).

«План S» залишає авторські права в руках авторів і скасовує видавничі ембарго на публікацію у відкритому доступі.

Ці принципи застосовуються до всіх видів наукових публікацій, однак досягнення відкритого доступу для монографій та книг може відбутися пізніше 1 січня 2021 року.

(https/www.coalition-s.org/why-plan-s/; https://101innovations.wordpress.com/2018/12/05/oa-potentialjournals-and-publications-across-disciplines/).

8. За цих обставин вважаємо недоцільним формувати жорсткі умови щодо присудження наукових ступенів та присвоєння вчених звань з фіксацією вимог опублікування статей у виданнях, присутніх у базах WoS, а тим більше, Scopus. 


\section{Пропонована класифікація міжнародних систем цитування (наукометричних систем та бібліографічних баз):}

1) універсальні (транснаукові, міждисциплінарні) реферативні бази - Web of Science, EBSCO, Scopus, DOAJ, OCLC WorldCat, MIAR, Genamics JournalSeek, Springer, Open Academic Journals Index, PИHЦ/RSCI, Academic Resource Index (Research Bib), Directory of Research Journals Indexing, Index Copernicus, Global Impact Factor, Genamics JournalSeek тощо;

2) спеціалізовані (галузеві) - Astrophysics, ERIH PLUS, PubMed, MathSciNet, Mathematics, Chemical Abstracts, Agris, GeoRef тощо.

3) наукометричні електронні бібліотеки/репозитарії/каталоги індексації міжнародних наукових журналів та матеріалів - Ulrich's Periodicals Directory, ROAR (Registry of Open Access Repositories), Directory Indexing of International Research Journals, International Scientific Indexing, Directory of Research Journals Indexing, CiteFactor, Киберленинка, Universal Impact Factor, NewJour, International Scientific Indexing та ін.

4) міжнародні системи академічних ресурсів/соціальні наукові і наукометричні мережі - ResearcherGate, SciPeople, Mendeley, Linkedln, Academia.edu тощо.

5) Google Scholar (Google Академія) - вільнодоступна міжнародна наукометрична та індексувальнорейтингова і пошукова система, яка індексує повнотекстові наукові публікації усіх форматів, з усіх дослідницьких напрямів і дисциплін. Google Scholar індексує більшість електронних ресурсів (бази, бібліотеки, репозитарії, сховища тощо), рецензованих онлайн-журналів світу і найбільших наукових видавництв. Google Академія - глобальна наукометрична пошукова та міжнародна індексувальна система і бібліометрична база даних, яка індексує метадані наукових публікацій з усіх галузей знання, опубліковані у різних форматах. Індекс Google Академії містить у собі більшість рецензованих журналів Європи та Америки найбільших наукових видавництв. Цей продукт має інструментарій для відслідковування наукової цитованості проіндексованих публікацій. Хоча компанія Google офіційно не розголошує обсяг індексу Google Академії, фахівцями цей обсяг оцінюється приблизно у 160 млн документів. 
Структуризація та класифікація наукометричного інструментарію, систем, баз, методів

\begin{tabular}{|c|c|c|c|c|}
\hline Назва & Короткий опис & Класифікація & Інтернет доступ & $\begin{array}{l}\text { Режим } \\
\text { доступу }\end{array}$ \\
\hline $\begin{array}{l}\text { Web of } \\
\text { Science }\end{array}$ & $\begin{array}{l}\text { Реферативна наукометрична база даних } \\
\text { наукових публікацій проекту Web of Knowledge } \\
\text { компанії Thomson Reuters. } \\
\text { Наукометричний апарат платформи забезпечує } \\
\text { відстеження показників цитованості публікацій } \\
\text { з ретроспективою до } 1900 \text { p. } \\
\text { Включає три бази - Science Citation Index } \\
\text { Expanded (природничі науки), Social Sciences } \\
\text { Citation Index (суспільні науки), Arts and } \\
\text { Humanities Citation Index (мистецтво та } \\
\text { гуманітарні науки). Одним з ключових } \\
\text { концептів наукометричного апарату платформи } \\
€ \text { імпакт-фактор (індекс впливовості) наукового } \\
\text { видання. }\end{array}$ & $\begin{array}{l}\text { Універсальна*, } \\
\text { міжнародна }\end{array}$ & $\begin{array}{l}\text { https://clarivate.com/pr } \\
\text { oducts/web-of-science/ } \\
\text { http://mjl.clarivate.com } \\
\text { /cgi- } \\
\text { bin/jrnlst/jloptions.cgi?P } \\
\text { C=H } \\
\text { http://mjl.clarivate.com } \\
\text { /cgi- } \\
\text { bin/jrnlst/jloptions.cgi?P } \\
\mathrm{C}=\text { EX } \\
\text { http://mjl.clarivate.com } \\
\text { /cgi- } \\
\text { bin/jrnlst/jloptions.cgi?P } \\
\text { C=SS }\end{array}$ & $\begin{array}{l}\text { База даних } \\
\text { доступна за } \\
\text { умов підписки }\end{array}$ \\
\hline Scopus & $\begin{array}{l}\text { Найбільша в світі єдина реферативна база } \\
\text { даних і наукометрична платформа, що була } \\
\text { створена в } 2004 \text { р. видавничою корпорацією } \\
\text { Elsevier. } \\
\text { Наукометричний апарат бази даних забезпечує } \\
\text { облік публікацій науковців і установ, у яких } \\
\text { вони працюють, та статистику їх цитованості. } \\
\text { Scopus надає гіперпосилання на повні тексти } \\
\text { матеріалів. }\end{array}$ & $\begin{array}{l}\text { Універсальна, } \\
\text { міжнародна }\end{array}$ & $\begin{array}{l}\text { https://www.elsevier.co } \\
\text { m/solutions/scopus } \\
\text { https://www.scopus.co } \\
\text { m/ }\end{array}$ & $\begin{array}{l}\text { База даних } \\
\text { доступна за } \\
\text { умов підписки }\end{array}$ \\
\hline $\begin{array}{l}\text { Google } \\
\text { Scholar }\end{array}$ & 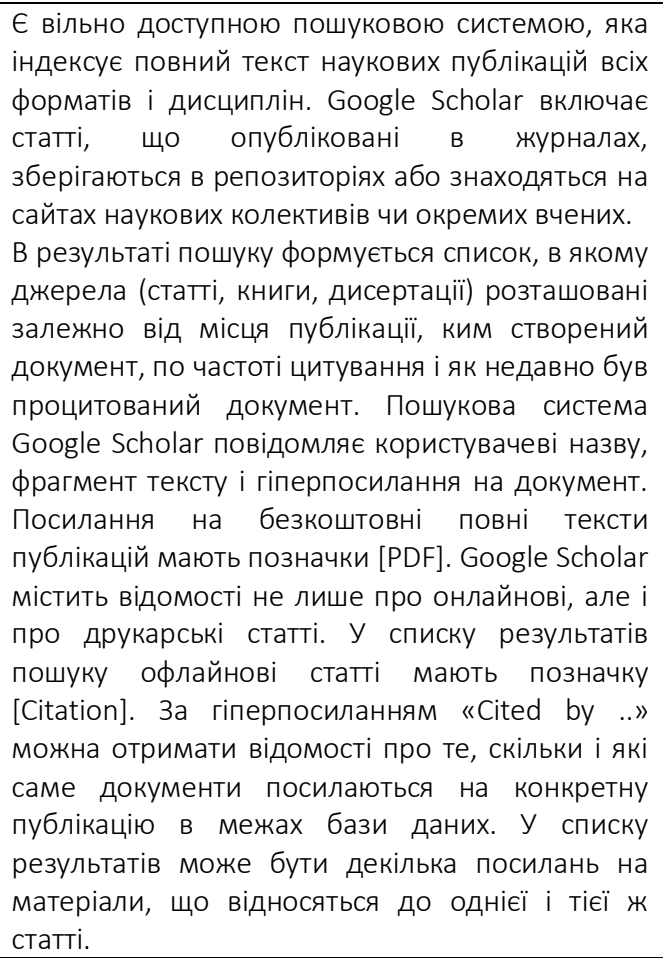 & $\begin{array}{l}\text { Універсальна, } \\
\text { міжнародна }\end{array}$ & $\begin{array}{l}\text { https://scholar.google.c } \\
\text { om.ua/ } \\
\text { https://scholar.google.c } \\
\text { om/ }\end{array}$ & Вільний доступ \\
\hline EBSCO & $\begin{array}{l}\text { Це доступні через веб-інтерфейс бази } \\
\text { даних наукової інформації з галузей медицини, } \\
\text { фізики, хімії, економіки та інших наук, що } \\
\text { періодично оновлюються. Власником } \\
\text { EBSCOhost } є \text { компанія EBSCO Publishing, яка, у } \\
\text { свою чергу, є дочірньо компанією EBSCO } \\
\text { Industries. } \\
\text { EBSCOhost надає можливість пошуку } \\
\text { повнотекстових, рецензованих статей наукових } \\
\text { журналів, довідників та інших публікацій з } \\
\text { різних наукових дисциплін. Включає в себе як } \\
\text { бази данихдоступні на умовахпередплати, так і } \\
\text { бази даних, які знаходяться у відкритому }\end{array}$ & $\begin{array}{l}\text { Універсальна, } \\
\text { міжнародна }\end{array}$ & $\begin{array}{l}\text { https://www.ebsco.com } \\
\text { / }\end{array}$ & $\begin{array}{l}\text { На умовах } \\
\text { передплати та } \\
\text { відкритий } \\
\text { доступ }\end{array}$ \\
\hline
\end{tabular}




\begin{tabular}{|c|c|c|c|c|}
\hline & доступі. & & & \\
\hline $\begin{array}{l}\text { Index } \\
\text { Copernicus }\end{array}$ & $\begin{array}{l}\text { Наукометрична база - включає індексування, } \\
\text { ранжування та реферування журналів, а такожє } \\
\text { платформою для наукової співпраці та } \\
\text { виконання спільних наукових проектів. База } \\
\text { даних має кілька інструментів для оцінки } \\
\text { продуктивності, що дозволяють відслідковувати } \\
\text { вплив наукових робіт і публікацій окремих } \\
\text { учених або наукових установ. На додаток до } \\
\text { оцінки продуктивності, індекс Копернік також } \\
\text { пропонує традиційні реферування та } \\
\text { індексування наукових публікацій. Національна } \\
\text { база, але як і РІнц та інші носить міжнародний } \\
\text { характер. }\end{array}$ & $\begin{array}{l}\text { Універсальна, } \\
\text { національна } \\
\text { (Польща) }\end{array}$ & $\begin{array}{l}\text { http://www.indexcoper } \\
\text { nicus.com/index.php/pl } \\
\text { / }\end{array}$ & $\begin{array}{l}\text { Ресурс } \\
\text { доступний } \\
\text { вільно }\end{array}$ \\
\hline $\begin{array}{l}\text { Journal } \\
\text { Citation } \\
\text { Reports }^{\circledR}\end{array}$ & $\begin{array}{l}\text { Система об'єктивного оцінювання і порівняння } \\
\text { провідних світових науково-дослідних журналів } \\
\text { шляхом складання статистики їх цитування та } \\
\text { кількості публікацій практично за всіма } \\
\text { галузями природничих, соціальних та } \\
\text { прикладних наук. JCR аналізує понад } 7600 \\
\text { журналів за } 220 \text { дисциплінами, які публікуються } \\
3300 \text { видавництвами по всьому світу та } \\
\text { допомагає виявити найбільш впливові видання } \\
\text { в окремій галузі науки. JCR має два видання: JCR } \\
\text { Science Edition та JCR Social Sciences Edition. }\end{array}$ & Універсальна & $\begin{array}{l}\text { https://clarivate.com/pr } \\
\text { oducts/journal-citation- } \\
\text { reports/ }\end{array}$ & $\begin{array}{l}\text { Доступ за умов } \\
\text { підписки }\end{array}$ \\
\hline $\begin{array}{l}\text { Scimago } \\
\text { Journal \& } \\
\text { Country Rank } \\
\text { (SJR) }\end{array}$ & $\begin{array}{l}\text { Сайт показника рівня цитованості наукових } \\
\text { журналів більше } 230 \text { країн світу на базі } \\
\text { інформаційної системи Scopus (Elsevier BV). } \\
\text { Показники можуть бути використані для оцінки } \\
\text { і аналізу наукових областей. }\end{array}$ & Універсальна & $\begin{array}{l}\text { http://www.scimagojr.c } \\
\text { om/ }\end{array}$ & $\begin{array}{l}\text { Ресурс } \\
\text { доступний } \\
\text { вільно }\end{array}$ \\
\hline РИНЦ/RSCI & $\begin{array}{l}\text { Російський індекс наукового цитування (РИНЦ) } \\
\text { створюється Науковою електронною } \\
\text { бібліотекою еLIBRARY.ru. в рамках проекту, } \\
\text { ініційованого Федеральним агентством з науки } \\
\text { та інновацій (Роснаука). Основним таким } \\
\text { критерієм є відносний показник цитування } \\
\text { статей, опублікованих в даному журналі, тобто, } \\
\text { його імпакт-фактор. }\end{array}$ & $\begin{array}{l}\text { Універсальна, } \\
\text { національна } \\
\text { (Росія) }\end{array}$ & $\begin{array}{l}\text { https://elibrary.ru/defa } \\
\text { ultx.asp }\end{array}$ & $\begin{array}{l}\text { Реєстрація } \\
\text { користувача в } \\
\text { Науковій } \\
\text { електронній } \\
\text { бібліотеці } \\
\text { необхідною } \\
\text { умовою для } \\
\text { отримання } \\
\text { доступу до } \\
\text { повних текстів } \\
\text { публікацій, } \\
\text { розміщених на } \\
\text { платформі } \\
\text { eLIBRARY.RU }\end{array}$ \\
\hline $\begin{array}{l}\text { Open } \\
\text { Academic } \\
\text { Journals } \\
\text { Index }\end{array}$ & $\begin{array}{l}\text { Повнотекстова база даних наукових журналів з } \\
\text { відкритим доступом. засновником } € \\
\text { International Network Center for Fundamental } \\
\text { and Applied Research, Pociя }\end{array}$ & $\begin{array}{l}\text { Універсальна } \\
\text { (Росія) }\end{array}$ & http://oaji.net/ & $\begin{array}{l}\text { Відкритий } \\
\text { доступ }\end{array}$ \\
\hline $\begin{array}{l}\text { Academic } \\
\text { Resource } \\
\text { Index } \\
\text { (Research } \\
\text { Bib) }\end{array}$ & $\begin{array}{l}\text { Безкоштовна академічна база даних, яка } \\
\text { індексує та надає відкритий доступ до } \\
\text { рецензованих журналів, повних текстових } \\
\text { статей, дослідницьких конференцій тощо }\end{array}$ & Універсальна & $\begin{array}{l}\text { http://journalseeker.res } \\
\text { earchbib.com/ } \\
\text { https://www.researchbi } \\
\text { b.com/ }\end{array}$ & $\begin{array}{l}\text { Відкритий } \\
\text { доступ }\end{array}$ \\
\hline $\begin{array}{l}\text { Directory of } \\
\text { Research } \\
\text { Journals } \\
\text { Indexing }\end{array}$ & $\begin{array}{l}\text { Директорія індексації журналів з наукових } \\
\text { досліджень» (DRJI) - одна з найбільш об'ємних } \\
\text { пошукових систем у світі, спеціально для } \\
\text { академічних відкритих веб-ресурсів. } \\
\text { Індексування науково-дослідницьких журналів } \\
- \text { це цифрова колекція досліджень та } \\
\text { інформації. Кожен запис DRJ містить } \\
\text { бібліографічні дані (назву, автор, ISSN або ISBN, } \\
\text { інформацію про видавця тощо) та реферат. }\end{array}$ & Універсальна & http://olddrji.lbp.world/ & $\begin{array}{l}\text { Відкритий } \\
\text { доступ }\end{array}$ \\
\hline $\begin{array}{l}\text { Global } \\
\text { Impact } \\
\text { Factor }\end{array}$ & & Універсальна & & \\
\hline
\end{tabular}




\begin{tabular}{|c|c|c|c|c|}
\hline $\begin{array}{l}\text { Український } \\
\text { індекс } \\
\text { наукового } \\
\text { цитування }\end{array}$ & $\begin{array}{l}\text { Система наукометричного моніторингу суб'єктів } \\
\text { наукової діяльності України. Призначення } \\
\text { системи - забезпечення збору, обробки та } \\
\text { надання доступу до даних щодо показників } \\
\text { активності індивідуальних та колективних } \\
\text { суб'єктів наукової діяльності України. Станом на } \\
\text { 09.10.2017 р. за даними Open Science in } \\
\text { Ukraine в Scopus та Web of Science індексується } \\
89 \text { журналів України. Режим доступу: } \\
\text { https://uk.wikipedia.org/wiki/Scopus }\end{array}$ & $\begin{array}{l}\text { Універсальна, } \\
\text { національна } \\
\text { (Україна) }\end{array}$ & http://uincit.uran.ua/ & $\begin{array}{l}\text { Ресурс } \\
\text { доступний } \\
\text { вільно }\end{array}$ \\
\hline $\begin{array}{l}\text { Genamics } \\
\text { JournalSeek }\end{array}$ & $\begin{array}{l}\text { Найбільша повністю класифікована база даних } \\
\text { вільно доступної журнальної інформації, } \\
\text { доступної в Інтернеті. В даний час база даних } \\
\text { містить } 41274 \text { назви. Інформація про журнали } \\
\text { містить опис (цілі та обсяги), скорочення } \\
\text { журналів, посилання на домашню сторінку } \\
\text { журналу, категорію предметів та ISSN. }\end{array}$ & Універсальна & http://journalseek.net/ & $\begin{array}{l}\text { Відкритий } \\
\text { доступ }\end{array}$ \\
\hline Astrophysics & $\begin{array}{l}\text { Астрофізична інформаційна } \\
\text { система HACA (англ. ADS - Astrophysics Data } \\
\text { System') - база даних фахової літератури } 3 \\
\text { астрономії та фізики. На } 2015 \text { рік база даних } \\
\text { має } 8000000 \text { документів астрономії та фізики з } \\
\text { рецензованих та нерецензованих джерел. } \\
\text { Майже для всіх статей в системі доступні } \\
\text { безкоштовні реферати. Відскановані давніші } \\
\text { статті розміщені у форматах GIF та PDF. }\end{array}$ & Спеціалізована* & http://ads.harvard.edu/ & $\begin{array}{l}\text { Відкритий } \\
\text { доступ }\end{array}$ \\
\hline PubMed & $\begin{array}{l}\text { Електронна база даних медичних і біологічних } \\
\text { публікацій, в якій викладені абстракти } \\
\text { публікацій англійською мовою; PubMed } \\
\text { створено на основі розділу «біотехнологія» } \\
\text { Національної медичної бібліотеки США. }\end{array}$ & Спеціалізована & $\begin{array}{l}\text { https://www.ncbi.nlm.n } \\
\text { ih.gov/pubmed/ }\end{array}$ & $\begin{array}{l}\text { Відкритий } \\
\text { доступ }\end{array}$ \\
\hline MathSciNet & $\begin{array}{l}\text { Реферативна база даних у сфері математики. } \\
\text { Вона містить майже } 3 \text { мільйони документів і } \\
\text { більше 1,7 мільйонів посилань на оригінальні } \\
\text { статті. }\end{array}$ & Спеціалізована & $\begin{array}{l}\text { https://mathscinet.ams. } \\
\text { org/mathscinet/help/ab } \\
\text { out.html?version=2 }\end{array}$ & $\begin{array}{l}\text { Доступ за } \\
\text { умови } \\
\text { передплати }\end{array}$ \\
\hline $\begin{array}{l}\text { Chemical } \\
\text { Abstracts }\end{array}$ & $\begin{array}{l}\text { Chemical Abstracts Service засновано у } 1907 \text { році } \\
\text { як відділення Американського хімічного } \\
\text { товариства. Його видавничому органу - } \\
\text { Chemical Abstracts поставлено завдання } \\
\text { реферування та індексації усіх релевантних } \\
\text { публікацій з хімії. }\end{array}$ & Спеціалізована & https://www.cas.org/ & $\begin{array}{l}\text { При закупівлі } \\
\text { ліцензії CAS } \\
\text { дає } \\
\text { комп'ютерну } \\
\text { програму } \\
\text { SciFinder для } \\
\text { онлайнового } \\
\text { пошуку у своїх } \\
\text { базах даних. } \\
\text { Дещо } \\
\text { обмежена } \\
\text { версія SciFinder } \\
\text { Scholar часто } \\
\text { використовуєт } \\
\text { ься в освітніх } \\
\text { закладах }\end{array}$ \\
\hline Springer & $\begin{array}{l}\text { Глобальна видавнича компанія, що видає } \\
\text { книги, електронні книги, і рецензовані журнали } \\
\text { на наукову, технологічну і медичну тематику. } \\
\text { Springer також розміщає у себе велику кількість } \\
\text { наукових баз даних, таких як SpringerLink, } \\
\text { Springer Protocols та Springerlmages. }\end{array}$ & Спеціалізована & $\begin{array}{l}\text { http://www.springer.co } \\
\text { m/gp/ }\end{array}$ & $\begin{array}{l}\text { Відкритий } \\
\text { доступ } \\
\text { анотацій, } \\
\text { публікації } \\
\text { оплату }\end{array}$ \\
\hline Agris & $\begin{array}{l}\text { Міжнародна бібліографічна база даних з більш } \\
\text { ніж } 7.5 \text { мільйонів структурованих } \\
\text { бібліографічних даних по сільському } \\
\text { господарству і суміжних дисциплін. База даних } \\
\text { адмініструється продовольчою } \\
\text { сільськогосподарською організацією } \\
\text { Об'єднаних Націй; дані надходять з понад } 150 \\
\text { установ з } 65 \text { країн світу. }\end{array}$ & Спеціалізована & $\begin{array}{l}\text { http://agris.fao.org/agri } \\
\text { s-search/index.do }\end{array}$ & $\begin{array}{l}\text { Відкритий } \\
\text { доступ до } \\
\text { анотацій }\end{array}$ \\
\hline
\end{tabular}




\begin{tabular}{|c|c|c|c|c|}
\hline GeoRef & $\begin{array}{l}\text { База даних GeoRef, створена Американським } \\
\text { інститутом наук про Землю в } 1966 \text { році, } \\
\text { забезпечує доступ до геоінформаційної } \\
\text { літератури світу. GeoRef - це найповніша база } \\
\text { даних в галузі наук про Землю та продовжує } \\
\text { зростати більш ніж на } 100000 \text { посилань на рік. } \\
\text { База даних містить понад 3,9 мільйонів } \\
\text { посилань на журнальні статті, книги, карти, } \\
\text { документи конференцій, доповіді та тези. }\end{array}$ & Спеціалізована & $\begin{array}{l}\text { https://www.americang } \\
\text { eosciences.org/georef/h } \\
\text { ow-access-georef }\end{array}$ & $\begin{array}{l}\text { Доступ за } \\
\text { підпискою }\end{array}$ \\
\hline CiteFactor & $\begin{array}{l}\text { CiteFactor забезпечує індексування журналів, } \\
\text { індексування дослідницьких робіт, фактор } \\
\text { впливу та аналіз цитування. Citefactor - це } \\
\text { каталог міжнародних наукових журналів у } \\
\text { співпраці з провідними університетами. }\end{array}$ & $\begin{array}{l}\text { Електронна } \\
\text { бібліотека/катал } \\
\text { ог індексації } \\
\text { міжнародних } \\
\text { наукових } \\
\text { журналів }\end{array}$ & $\begin{array}{l}\text { http://www.citefactor.o } \\
\text { rg/ }\end{array}$ & \\
\hline $\begin{array}{l}\text { Киберленин } \\
\text { ка }\end{array}$ & $\begin{array}{l}\text { Наукова електронна бібліотека, побудована на } \\
\text { парадигмі відкритої науки (Ореп Science), } \\
\text { основними завданнями якої } є \text { популяризація } \\
\text { науки і наукової діяльності, громадський } \\
\text { контроль якості наукових публікацій, розвиток } \\
\text { міждисциплінарних досліджень, сучасного } \\
\text { інституту наукової рецензії, підвищення } \\
\text { цитованості російської науки і побудова } \\
\text { інфраструктури знань (Росія). }\end{array}$ & $\begin{array}{l}\text { Електронна } \\
\text { бібліотека/катал } \\
\text { ог індексації } \\
\text { міжнародних } \\
\text { наукових } \\
\text { журналів* }\end{array}$ & https://cyberleninka.ru/ & \\
\hline $\begin{array}{l}\text { International } \\
\text { Scientific } \\
\text { Indexing }\end{array}$ & $\begin{array}{l}\text { Сервер ISI забезпечує індексування основних } \\
\text { міжнародних журналів та матеріалів. Автор } \\
\text { може отримати інформацію про імпакт-фактор } \\
\text { міжнародного журналу, роботи (наукові статті) } \\
\text { та інформацію про майбутні події. Всі сторінки } \\
\text { журналу містять вказівки на веб-сторінки } \\
\text { видавців, які інтегровані в сторінки потоку ISI. }\end{array}$ & $\begin{array}{l}\text { Електронні } \\
\text { бібліотеки/катал } \\
\text { оги індексації } \\
\text { міжнародних } \\
\text { наукових } \\
\text { журналів }\end{array}$ & $\begin{array}{l}\text { http://isindexing.com/is } \\
\text { i/index.php }\end{array}$ & \\
\hline $\begin{array}{l}\text { Ulrich's } \\
\text { Periodicals } \\
\text { Directory }\end{array}$ & $\begin{array}{l}\text { База даних Ulrich's Periodicals Directory } \\
\text { американського видавництва Bowker } € \\
\text { найбільшою базою даних, що описує світовий } \\
\text { потік серіальних (періодичних і продовжуваних) } \\
\text { видань по всіх тематичних напрямках } \\
\text { життєдіяльності. БД містить описи майже } \\
\text { З00 тис. серіальних видань. }\end{array}$ & $\begin{array}{l}\text { Електронна } \\
\text { бібліотека/катал } \\
\text { ог індексації } \\
\text { міжнародних } \\
\text { наукових } \\
\text { журналів }\end{array}$ & $\begin{array}{l}\text { http://ulrichsweb.serials } \\
\text { solutions.com/login }\end{array}$ & $\begin{array}{l}\text { База даних } \\
\text { доступна за } \\
\text { умов підписки }\end{array}$ \\
\hline Mendeley & $\begin{array}{l}\text { Безкоштовне програмне забезпечення для } \\
\text { керування бібліографічною інформацією, яке } \\
\text { дозволяє зберігати та переглядати дослідницькі } \\
\text { праці у форматі PDF. Також це є соціальна } \\
\text { мережа для вчених, заснована в Лондоні в } \\
2007 \text { р. }\end{array}$ & $\begin{array}{l}\text { Міжнародні } \\
\text { системи } \\
\text { академічних } \\
\text { ресурсів* }\end{array}$ & $\begin{array}{l}\text { https://www.mendeley. } \\
\text { com/ }\end{array}$ & \\
\hline Linkedln & $\begin{array}{l}\text { Соціальна мережа для пошуку і встановлення } \\
\text { ділових контактів. у Linkedln зареєстровано } \\
\text { понад } 400 \quad \text { мільйонів користувачів, що } \\
\text { представляють } 150 \text { галузей бізнесу з } 200 \text { країн. }\end{array}$ & $\begin{array}{l}\text { Міжнародні } \\
\text { системи } \\
\text { академічних } \\
\text { ресурсів }\end{array}$ & $\begin{array}{l}\text { https://www.linkedin.co } \\
\text { m/ }\end{array}$ & \\
\hline $\begin{array}{l}\text { Academia.ed } \\
\mathrm{u}\end{array}$ & $\begin{array}{l}\text { Академія є однією з найпопулярніших наукових } \\
\text { соціальних мереж з 46,035,250 учасниками. } \\
\text { Дослідники можуть завантажувати свої } \\
\text { документи та спілкуватися з іншими вченими. } \\
\text { За даними веб-сайту Academia, «Academia - це } \\
\text { найпростіший спосіб обмінюватися } \\
\text { документами з мільйонами людей у всьому } \\
\text { світі безкоштовно». }\end{array}$ & $\begin{array}{l}\text { Міжнародні } \\
\text { системи } \\
\text { академічних } \\
\text { ресурсів }\end{array}$ & $\begin{array}{l}\text { https://www.academia. } \\
\text { edu/ }\end{array}$ & \\
\hline
\end{tabular}

Прим.: Таблиця вище відображає лище одні з основних наукометричних баз даних і не є вичерпною. 


\section{Наукометричні показники}

\begin{tabular}{|c|c|c|c|}
\hline Назва & Короткий опис & Інтернет доступ (деталі) & Примітки \\
\hline $\begin{array}{l}\text { Iндекс цитування / } \\
\text { Science Citation Index, } \\
\text { - SCI }\end{array}$ & 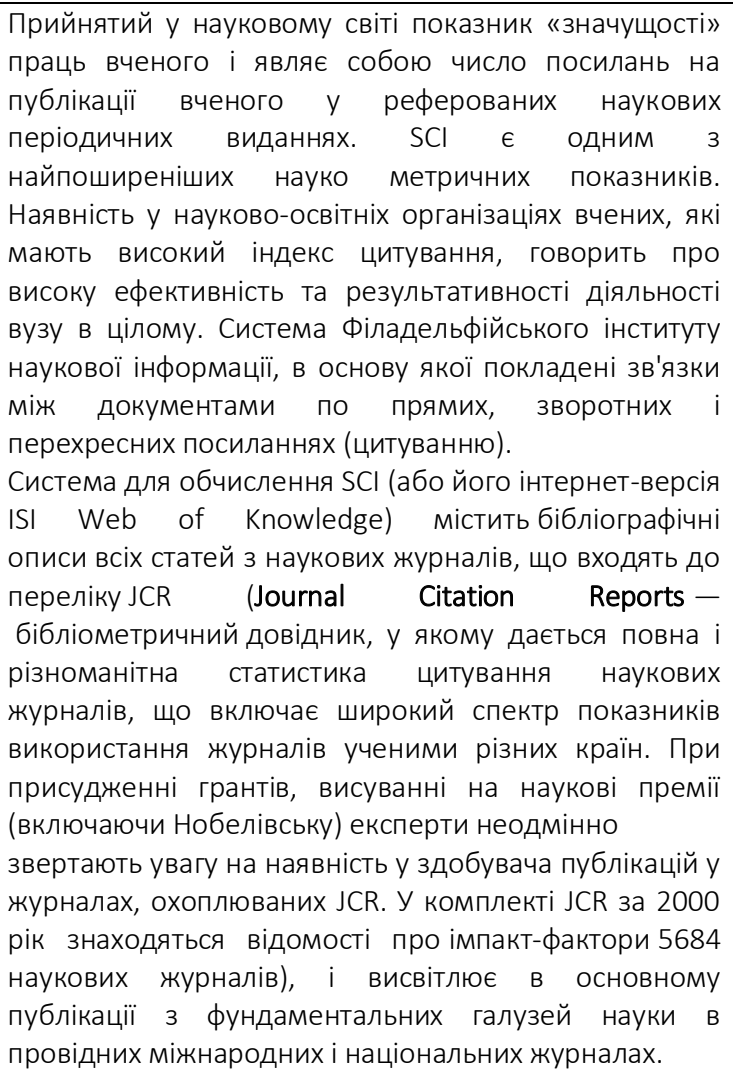 & 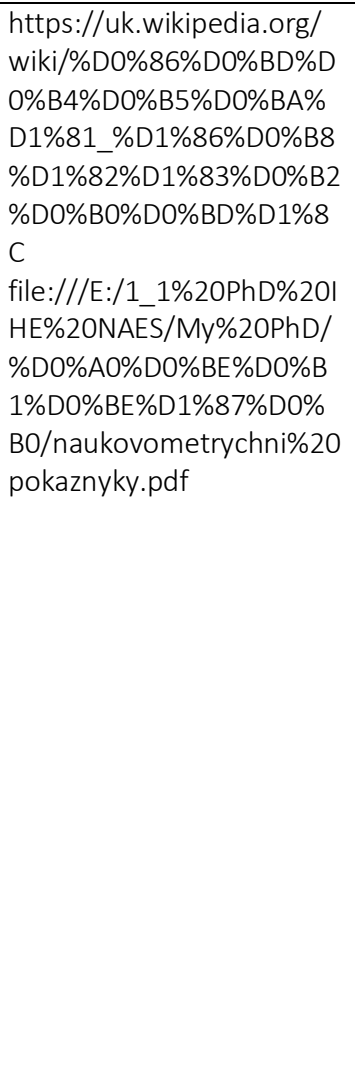 & $\begin{array}{lr}\text { Ключовий } & \text { показник } \\
\text { для оцінки } & \text { роботи } \\
\text { науковця } & \text { і } \\
\text { наукового } & \\
\text { колективу } & \end{array}$ \\
\hline Індекс Хірша/ h-index & 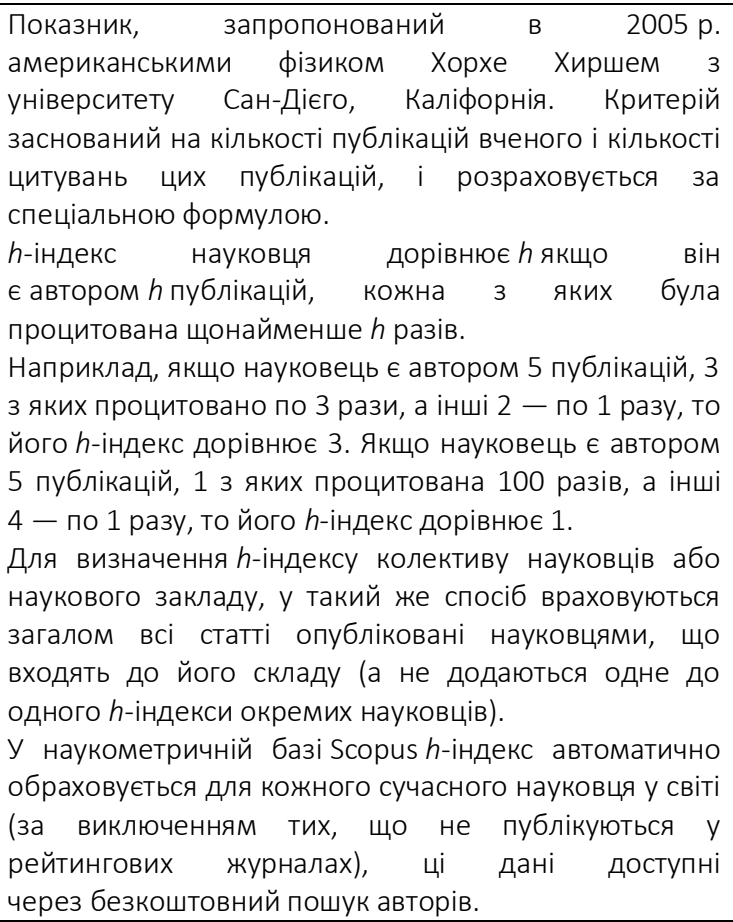 & $\begin{array}{l}\text { https://uk.wikipedia.org/ } \\
\text { wiki/H- } \\
\text { \%D1\%96\%D0\%BD\%D0\%B } \\
\text { 4\%D0\%B5\%D0\%BA\%D1\% } \\
81\end{array}$ & $\begin{array}{l}\text { Пов'язаний } \\
\text { середньою } \\
\text { цитованістю статей } \\
\text { науковця }\end{array}$ \\
\hline $\begin{array}{l}\text { Iмпакт-фактор / } \\
\text { impact-factor }\end{array}$ & 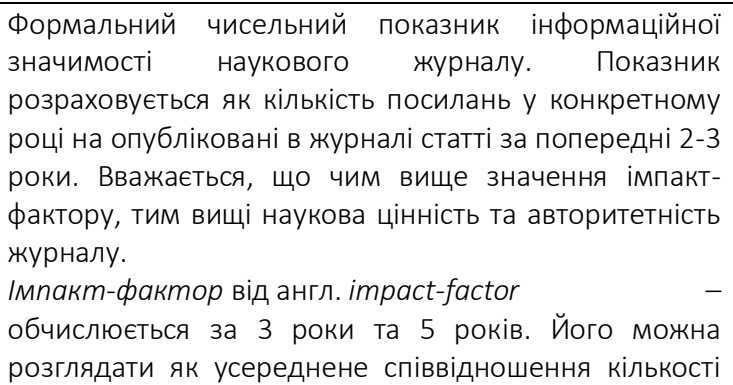 & $\begin{array}{l}\text { https://uk.wikipedia.org/ } \\
\text { wiki/\%D0\%9A\%D0\%BE\%D } \\
\text { 0\%B5\%D1\%84\%D1\%96\%D } \\
\text { 1\%86\%D1\%96\%D1\%94\%D } \\
\text { 0\%BD\%D1\%82_\%D0\%B2 } \\
\text { \%D0\%BF\%D0\%BB\%D0\%B } \\
\text { 8\%D0\%B2\%D0\%BE\%D0\% } \\
\text { B2\%D0\%BE\%D1\%81\%D1 } \\
\text { \%82\%D1\%96 }\end{array}$ & $\begin{array}{l}\text { Більше характеризує } \\
\text { рейтинг журналу та } \\
\text { його впливовість }\end{array}$ \\
\hline
\end{tabular}




\begin{tabular}{|c|c|c|c|}
\hline & 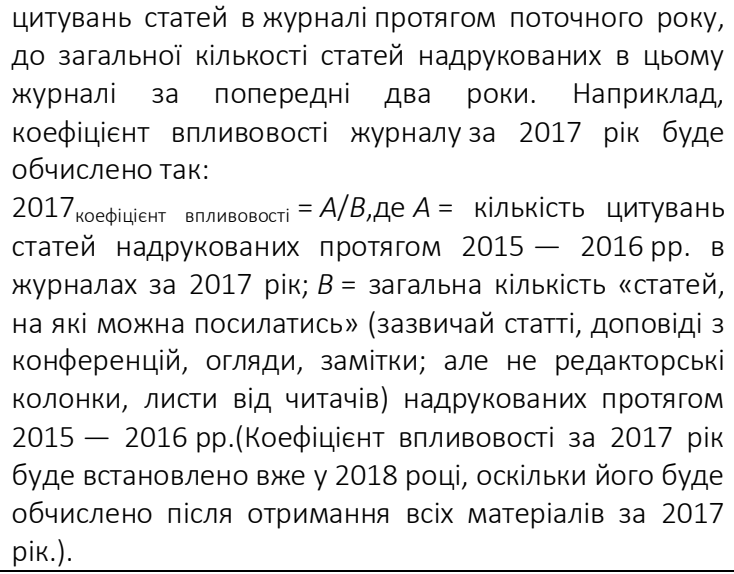 & & \\
\hline $\begin{array}{l}\text { SNIP (Source } \\
\text { Normalized Impact per } \\
\text { Paper) }\end{array}$ & $\begin{array}{l}\text { Показник SNIP (стандартний вплив джерела на } \\
\text { статтю) відображає вплив контекстної цитованості } \\
\text { журналу, що дозволяє безпосередньо порівнювати } \\
\text { журнали різної тематики, зважаючи на частоту, з } \\
\text { якою автори цитують інші джерела, швидкість } \\
\text { розвитку впливу цитати і ступінь відображення } \\
\text { літератури певного напряму базою даних. }\end{array}$ & $\begin{array}{l}\text { file:///E:/1_1\%20PhD\%20I } \\
\text { HE\%2ONAES/My\%2OPhD/ } \\
\text { \%D0\%A0\%D0\%BE\%D0\%B } \\
\text { 1\%D0\%BE\%D1\%87\%D0\% } \\
\text { B0/naukovometrychni\%20 } \\
\text { pokaznyky.pdf }\end{array}$ & $\begin{array}{lr}\text { Реферативна } & \text { база } \\
\text { даних } & \text { Sсориз } \\
\text { пропонує } & \text { цей } \\
\text { показник } & \text { як } \\
\text { альтернативний } & \\
\text { імпакт-фактору, } \\
\text { більше характеризує } \\
\text { рейтинг журналу та } \\
\text { його впливовість }\end{array}$ \\
\hline $\begin{array}{l}\text { SJR (SCImago Journal } \\
\text { Rank) }\end{array}$ & $\begin{array}{l}\text { Є рейтингом журналів, що дає можливість оцінити } \\
\text { науковий престиж робіт учених, виходячи з кількості } \\
\text { ваговитих цитат на кожен документ. Журнал наділяє } \\
\text { власним «престижем», або статусом, інші журнали, } \\
\text { цитуючи опубліковані в них матеріали. Фактично це } \\
\text { означає, що цитата з джерела з відносно високим } \\
\text { показником SJR має більшу цінність, ніж цитата з } \\
\text { джерела з нижчим показником SJR. }\end{array}$ & $\begin{array}{l}\text { file:///E:/1_1\%20PhD\%20I } \\
\text { HE\%2ONAES/My\%2OPhD/ } \\
\text { \%D0\%A0\%D0\%BE\%D0\%B } \\
\text { 1\%D0\%BE\%D1\%87\%D0\% } \\
\text { B0/naukovometrychni\%20 } \\
\text { pokaznyky.pdf }\end{array}$ & $\begin{array}{l}\text { Реферативна база } \\
\text { даних } \quad \text { Sсориs } \\
\text { пропонує цей } \\
\text { показник } \quad \text { як } \\
\text { альтернативний } \\
\text { імпакт-фактору, } \\
\text { більше характеризує } \\
\text { рейтинг журналу та } \\
\text { його впливовість }\end{array}$ \\
\hline І-індекс & $\begin{array}{l}\text { Індекс, що відображає публікаційну активність } \\
\text { наукової } \quad \text { організації, } \quad \text { розрахову.ється на } \\
\text { основі бібліометричних показників }\end{array}$ & $\begin{array}{l}\text { https://uk.wikipedia.org/ } \\
\text { wiki/\%D0\%9D\%D0\%B0\%D } \\
\text { 1\%83\%D0\%BA\%D0\%BE\% } \\
\text { D0\%BC\%D0\%B5\%D1\%82 } \\
\text { \%D1\%80\%D0\%B8\%D1\%87 } \\
\text { \%D0\%BD\%D1\%96_\%D0\% } \\
\text { BF\%D0\%BE\%D0\%BA\%D0 } \\
\text { \%B0\%D0\%B7\%D0\%BD\%D } \\
\text { 0\%B8\%D0\%BA\%D0\%B8 } \\
\end{array}$ & \\
\hline $\begin{array}{l}\text { IPP (Impact per } \\
\text { Publication) }\end{array}$ & $\begin{array}{l}\text { Компонент калькуляції } \mathrm{SNIP,} \text { який вимірює } \\
\text { співвідношення цитат за статтю, опубліковану в } \\
\text { журналі. }\end{array}$ & $\begin{array}{l}\text { https://www.elsevier.com } \\
\text { /connect/with-2013- } \\
\text { journal-rankings-no-one- } \\
\text { metric-rules-them-all }\end{array}$ & \\
\hline
\end{tabular}


Інструментарій інтернаціоналізації освітньо-наукової діяльності

\begin{tabular}{|l|l|}
\hline Наукометричні бази даних & $\begin{array}{l}\text { Інструмент і ресурс для висвітлення та поширення результатів наукових досліджень, } \\
\text { наукових праць та формування національного та міжнародного іміджу науковця, } \\
\text { наукового колективу, наукової інституції, закладу вищої освіти, обмін науковими } \\
\text { здобутками і не тільки }\end{array}$ \\
\hline Наукометричні показники & $\begin{array}{l}\text { Інструмент оцінки значущості наукової періодики, якості наукової роботи, } \\
\text { впливовості науковця, можливість залучення кращих науковців до співпраці у певних } \\
\text { сферахчи за певною тематикою, формування наукового іміджу вченого та його } \\
\text { затребуваності в обраній науковій сфері }\end{array}$ \\
\hline Elsevier Journal Metrics & $\begin{array}{l}\text { Наукометричний інструмент для оцінки наукових журналів за показниками: SNIP } \\
\text { (Source Normalized Impact per Paper), SJR (SCImago Journal Rank), Impact per Publication } \\
\text { (IPP) - https://www.elsevier.com/соnnect/with-2013-journal-rankings-no-оne-metric- } \\
\text { rules-them-all } \\
\text { httрs://јоurnalmetrics.scopus.com/ }\end{array}$ \\
\hline Вебометрика/ Webometrics & $\begin{array}{l}\text { Комплексний засіб для порівняння інтелектуального рівня і наукового внеску цілих } \\
\text { країн, акумуляції та порівняння наукових доробок та ресурсів }\end{array}$ \\
\hline $\begin{array}{l}\text { Інструментарій для визначення } \\
\text { рейтингів університетів }\end{array}$ & Оцінювання та рейтингування університетів за визначеними показниками \\
\hline
\end{tabular}




\section{Нагальні питання, висновки та пропозиції по розвитку інтеграції вищої освіти України до сучасної глобально-інтернаціональної системи наукометричного інструментарію якості}

\section{Проблемні питання}

- Що потрібно зробити, щоб українські університети входили до основних світових рейтингів?

- Які кроки потрібно зробити, щоб у справі інтернаціоналізації перейти від декларативного стану реалізації стратегії інтернаціоналізації на національному, регіональному, місцевому та інституційному рівнях до практичного втілення визначених ідей, поставлених цілей із використання кращих практик національного та міжнародного наукового просторів?

- Яким чином спрямувати та спонукати вітчизняного науковця сприйняти інтернаціоналізацію як сутність наукового життя, можливість для професійного зростання, формування міжнародного іміджу, значимості та затребуваності в національному та міжнародному дослідницькому світі?

\section{Пропозиції}

Кожен ЗВО (Заклад вищої освіти) та академічна наукова мають розробити дієву комплексну стратегію інтернаціоналізації установи з планом конкретних практичних заходів та принципами оцінювання якості їі реалізації та визначення стійкості отриманих результатів і подальшого впливу.

Створення національних дослідницьких мереж кращих науковців та їх активна співпраця із зарубіжними та світовими науковими інституціями та мережами, проведення спільних досліджень та спільне оприлюднення та поширення результатів з використанням основних наукометричних баз даних.

Створення національних наукометричних баз з використанням основних наукометричних показників та виведення їх на міжнародний рівень за рахунок активного міжнародного наукового співробітництва та залучення зарубіжних науковців до національних дослідницьких проектів.

Використання наукової міжнародної мобільності для встановлення нових наукових контактів, перейняття кращих світових наукових практик та розробки спільних наукових продуктів.

Започаткування національної платформи для науковців, яка здійснюватиме такі напрями діяльності:

- організація тренінгів та науково-практичних семінарів за визначеною тематикою, наприклад:

- маркетинг наукової діяльності та оприлюднення наукових розробок;

- практичні кроки у сфері міжнародної наукової діяльності та використанні наукометричних ресурсів і технологій;

- як орієнтуватися в світі наукових інтернет-ресурсів та користуватися світовою практикою формування власного наукового портрету тощо;

- ведення форуму науковців для обміну кращими практиками, формування тимчасових творчих колективів із залученням зарубіжних наукових зв'язків, презентації наукових доробок, реалізації спільних наукових проектів;

- організація вебінарів, наукових інтернет-мостів для вивчення та обговорення наукових інновацій, підходів та методів у сфері інтернаціоналізації наукової діяльності;

- стратегічна діяльність на формування критичної маси науковців-міжнародників, здатних просувати національну науку в міжнародний науковий простір і вільно користуватися світовим наукометричним інструментарієм.

1. В якості головної умови щодо оцінки якості публікацій для присудження наукових ступенів та присвоєння вчених звань у відповідних «Порядках присудження/присвоєння наукових ступенів/вчених звань» $\mathrm{MOH}$ визначити та вказати розширений перелік міжнародних наукометричних систем/баз на основі чітких та немонополістичних критеріїв, ґрунтуючись на наступному:

1.1. Обсязі, рівні (глобально-міжнародному) і кількості наукових матеріалів (наприклад, не менше 1000 найменувань видань, представлених у базі);

1.2.Універсальності, транснауковості, міжгалузевості та міждисциплінарності розміщених матеріалів тобто відсутності жорсткої спеціалізації;

1.3. Ступені ії «індексувальної відкритості» - можливості формування об'єктивних показників наукометричних рейтингів та цитованості;

1.4. Різноманітті та багатоманітності розміщених у базі матеріалів (не лише періодичні видання, але й збірки конференцій, матеріали симпозіумів, колекції винаходів, розробок тощо);

1.5. Ступені відкритості та доступності для використання розміщених у базі матеріалів. 
2. За даними критеріями пропонуємо включити до переліку міжнародних наукометричних баз (поряд з нині присутніми WoS та Scopus), публікації у виданнях, присутніх там, має визнаватися:

2.1. Універсальні, трансдисциплінарні та міжнаукові наукометричні ресурси, наявність публікацій в яких $€$ обов'язковою для усіх здобувачів наукових ступенів/вчених звань.

2.2. Професійно-спеціалізовані наукометричні ресурси.

3 урахування галузевої, наукової, дослідної спеціалізації сформувати та включити до «Порядку» МОН «Перелік спеціалізованих та галузевих міжнародних наукометричних систем/баз» відповідно до переліку спеціальностей, затверджених МOH.

Наводимо приклад подібних спеціалізованих галузевих систем індексації/наукометричних баз Astrophysics, PubMed, Mathematics, Chemical Abstracts, Agris, GeoRef тощо.

\section{3. Додаткові наукометричні ресурси.}

Виходячи з фундаментальності принципу освітянської та наукової автономії - дозволити спеціалізованим вченим радам та вченим радам 3ВО і наукових установ додавати (на постійній чи тимчасовій основі) до пп.1-2 даного Переліку групу (до 3-5) міжнародних наукометричних систем/баз, котрі, з точки зору провідних фахівців даної установи можуть бути враховані як такі, що додатково якісно відображають рівень наукових напрацювань даного вченого.

3. Розвивати якісну національну наукову ранжувально-інформаційну наукометричну систему, підключену до міжнародних наукометричних баз даних, і зафіксувати вимогу представленості усіх публікацій здобувача у цій системі. Зважаючи на існування великої кількості та різноманіття наукометричних систем, варто було б створити єдиний міжнародний наукометричний ресурс, до якого би підключилися, або інтегрувалися вже існуючі платформи. Простота і доступність інтерфейсу на багатьох мовах, залучення максимальної кількості індексів та інших оціночних показників, а також можливість задавати необхідний показник, або співвідношення за певними, індивідуально визначеними параметрами полегшили би і пришвидшили дослідження науковців в усьому світі.

Також створення і запровадження якісної української наукометричної бібліометричної і пошукової платформи, підкріпленої на законодавчому рівні, заслуговує на дослідження і обгрунтування в академічному просторі. 


\section{Висновки}

Виникнення наукометричних баз (систем, платформ) є природнім явищем у розвитку суспільства як спроба виміряти те, що з одного боку $\epsilon$ абстрактним, а 3 іншого - в результаті глибокого аналізу характеризується певними кількісними ознаками. Наукові дослідження зумовлюють прискорений розвиток технологій, отже на певному етапі виникла необхідність оцінити, тобто виміряти вагомість науководослідницького внеску вченого для розвитку певної галузі досліджень. Оскільки цю потребу відчули в різних країнах з відносно невеликою різницею у часі, були винайдені і розроблені різні наукометричні технології.

Щоб якісно підвищити та посилити наукометричні показники, за якими проводяться кількісні оцінки і порівняльний аналіз наукової активності авторів та наукових установ, потрібно публікуватися у закордонних і вітчизняних журналах, що входять до відомих наукометричних систем/баз, реєструватися й створювати свій авторський профіль в міннародних наукометричних базах.

Оскільки університети та наукові інституції (та й уся система вищої освіти і науки - як світу, так і України) прагнуть здобути високі позиції у рейтингах та показниках якості, а серед критеріїв оцінки вагомі позиції займають наукові здобутки професорсько-викладацького складу, включаючи кількісні і якісні показники їх наукових публікацій, актуальною проблемою постає доступність опанування наукометричними технологіями. Наполегливість керівництва і форсування процесу підвищення «наукової якості» призводять до а) низької якості публікацій; б) демотивації викладачів; в) кадрових рішень. Питання (проблема) полягає в тому, яким чином фасилітувати процес оволодіння навичками користування наукометричними базами академічного складу ЗВО. 


\section{Список використаних джерел}

1. Білощицький А.О. Наукометричні бази та індикатори цитування наукових публікацій / А.О. Білощицький, В.Д. Гогунський // Інформаційні технології в освіті, науці та виробництві. - Вип. 4 (5). - О.: АО Бахва, 2013. С. 198-203.

2. Бурков В.Н. Параметры цитируемости научных публикаций в наукометрических базах данных / В.Н. Бурков, А. А. Белощицкий, В. Д. Гогунский // Управління розвитком складних систем. 2013. № 15. С. 134139.

3. Зінченко В.В. Інструменти інтернаціоналізації наукової діяльності//Інтернаціоналізація вищої освіти в Україні: методичні рекомендації / Л. Горбунова, М. Дебич, В. Зінченко, І. Сікорська, І. Степаненко, О. Шипко / За ред. І. Степаненко. К.: ІВО НАПН України, 2016. 158 с. Розділ 6. С.121-157.

4. Лейденський маніфест для наукометрії. URL: http://www.igh.ru/about/news/1053/.

5. Оборський Г.О. Нові тенденції і завдання щодо підготовки науковців вищої кваліфікації/ Г.О.Оборський,В.Д. Гогунський // Інформаційні технології в освіті, науці та виробництві. Вип. 2. Одеса: А.О. Бахва, 2013. С. 15-22.

6. Hirsch J.E. An index to quantify an individual's scientific research output [Текст] // arXiv: physics/0508025. v5. 29 Sep. 2005. 5 p.

7. Kramer B., Bosman J. Innovations in scholarly communication - global survey on research tool usage. F1000Research. 2016. № 5. P. 692. URL: https://doi.org/10.12688/f1000research.8414.1.

8. Leydesdorff L., Wouters P., Bornmann L. Professional and citizen bibliometrics: complementarities and ambivalences in the development and use of indicators-a state-of-the-art report. Scientometrics. 2016. 109, № 3. P. 2129-2150. URL: https://doi.org/10.1007/s11192-016-2150-8.

9. McVeigh M. E. Open Access Journals in the ISI Citation Databases: Analysis of Impact Factors and Citation Patterns: a citation study from Thomson Scientific. URL: http://:science.thomsonreuters.com/m/pdfs/openaccesscitations2.pdf.

10. Moed H.F., Luwel M., Nederhof A. J. Towards indicators of research performance in the humanities. Library Trends. 2002, № 50. P. 498-520.

11. Rousseau R. New developments related to the Hirsch index//Science Focus. URL: http://eprints.rclis.org/6376/.

12.Shotton D. Open citations. Nature. 2013. 502, № 7471. P. 295-297. URL: https://doi.org/10.1038/502295a.

13. Waltman L., Noyons L. Bibliometrics for Research Management and Research Evaluation. Leiden: Centre for Science and Technology Studies. 2018. URL: https://www.cwts.nl/pdf/CWTS_bibliometrics.pdf. 


\section{Список додаткових джерел}

1. Бібліометрика української науки: інформаційно-аналітична система / Л. Костенко, О. Жабін, О. Кузнєцов, Є. Кухарчук, Т. Симоненк. Бібліотечний вісник. 2014. № 4.С. 8-12.

2. Коляда, А. С. Автоматизация извлечения информации из наукометрических баз данных / А.С. Коляда, В.Д. Гогунский. Управління розвитком складних систем. 2013. № 16. С. 96 - 99.

3. Костирко, Т. Н. Університети України: приєднання до руху відкритого доступу. Вісник ОНУ. Том 16. Випуск 1/2 (5/6). 2011. С. 283-289.

4. Рейтинг кращих університетів світу за версією QS. URL: http://gtmarket.ru/ratings/qs-worlduniversity-rankings/info.

5. Світовий рейтинг університетів - перелік кращих 3ВО Times Higher Education World University Rankings. URL: http://www.timeshighereducation.co.uk/world-university-rankings/.

6. Слащева Н. А. Критерии отбора источников для ресурса Web of Science на платформе Web of Knowledge. URL: http://elibrary.ru/projects/events/conf_vak_rinc/presentations/Slashcheva2.ppt.

7. Шанхайський рейтинг кращих ЗBO світу: ARWU. URL: http://www.educationmedelle.com/articles/schankhajskij-rejting-luchschikh-vuzov-mira-arwu.html.

8. Яцків T.M. Цифрові ідентифікатори DOI (The Digital Object Identifier) для наукових публікацій: принцип роботи та можливості бази даних агентства Crossref. Наука України у світовому інформаційному просторі. Вип. 13. К. : Академперіодика, 2016. С. 73-79. URL: https://doi.org/10.15407/akademperiodyka.321.073.

9. Peroni S., Dutton A., Gray T., Shotton D. Setting our bibliographic references free: towards open citation data. Journal of Documentation. 2015. 71, № 2. P. 253-277. URL: https://doi.org/10.1108/JD-12-2013-0166.

10. Rankings of Scientists: More countries! URL: http://webometrics.info/en/node/116.

11.Scopus works with European Science Foundation to expand Arts \& Humanities coverage. URL: http://www.info.sciverse.com/scopusnews/scopus-works-european-science-foundation-expand-arts-humanitiescoverage.

12.Testa J. The Thomson Reuters Journal Selection Process. URL: http://thomsonreuters.com/products_services/science/free/essays/journal_selection_process/.

13. Web of Science. URL: http://thomsonreuters.com/products_services/science/science_products/az/web_of_science/. 


\title{
Розділ III. Освіта для стійкого розвитку: рекомендації до впровадження на основі трансформативного навчання
}

\author{
Людмила Горбунова, \\ доктор філософських наук, дочент, \\ головний науковий співробітник \\ відділу інтернаціоналізації вищої освіти \\ Інституту вищої освіти НАПН України \\ https://orcid.org/0000-0002-5388-145X
}

Анотація. Дані рекомендації сформульовані на основі аналізу документів міжнародних організацій та окремих інституціональних досліджень досвіду впровадження Освіти для стійкого розвитку (ESD Education for Sustainable Development) на основі трансрормативного навчання, яка дає учням можливість приймати усвідомлені рішення і проводити відповідальні заходи для забезпечення екологічної чілісності, економічної життєздатності і справедливого суспільного устрою для нинішнього і майбутніх поколінь при повазі культурного розмаїття. ESD сприяє цілісній і трансформативній освіті. Цей тип освіти стосується змісту і результатів навчання, інноваційної педагогіки і «навчання на практиці» («learning bу doing») і використовує цілісний загальноінституціональний підхід для залучення спільнот в досягнення стійких змін. ESD знаходиться у центрі Порядку денного у галузі стійкого розвитку на період до 2030 року і отримала широке визнання у якості ключового фактора стійкого розвитку і невід'ємного елементу якісної освіти. Він є частиною Цілі 4 в області стійкого розвитку, яка до 2030 року прагне забезпечити те, щоб всі учні придбали знання і навички, необхідні для сприяння стійкому розвитку, в тому числі за допомогою освіти для стійкого розвитку та стійкого способу життя, а також пронизує всі інші цілі у галузі стійкого розвитку (SDGs - Sustainable Development Goals).

Рекомендації включають в себе: обгрунтування впровадження ESD в українську освіту як порядку денного для ії ресормування на основі документів UN, UNESCO, OECD та досліджень новітнього міжнародного досвіду трансрормативного навчання у закладах вищої освіти; аналіз змісту кониепта Освіти для стійкого розвитку та його еволючії, тенденції інтеграції освіти у стійкий розвиток та роль освіти у досягненні цілей стійкого розвитку; розглянута Глобальна програма дій в області Освіти для стійкого розвитку; проаналізована дискусія стосовно ключових компетентностей, які має надавати освіта для стійкого розвитку; визначені ключові теми і результати навчання, а також орієнтації щодо викладання, навчання та оцінювання, тобто того, як допомогти студентам у досягненні ними відповідних результатів і вмінні продемонструвати їх. 


\section{Передмова}

Дані методичні рекомендації призначені для надання практичної допомоги закладам вищої освіти, які прагнуть включити Освіту для стійкого розвитку в програму навчання своїх студентів. Вони спрямовані на надання методичної допомоги викладачам з метою формування у студентів знання, розуміння і навичок в області стійкого розвитку. Дані рекомендації можна використовувати при розробленні навчальних програм усіх дисциплін, а також як загальне керівництво для релевантних підходів до викладання, навчання та оцінювання.

Дані рекомендації в першу чергу будуть корисні для викладачів і розробників програм навчання у закладах вищої освіти. Разом з тим вони можуть бути цікавими для тих, хто відповідає за якість вищої освіти, а також за організацію навчання як в рамках навчальних програм, так і в контексті позааудиторних заходів. Рекомендації можуть представляти безпосередній інтерес для студентів, а також для всіх, хто хоче зрозуміти, яким чином знання і розуміння проблем стійкого розвитку можуть бути включені в процес навчання на рівні закладів вищої освіти.

Дані рекомендації можуть слугувати орієнтиром для розроблення навчальної програми, для їі викладання і перевірки результатів навчання. Їх можна використовувати як основу для розроблення інтегративної програми стійкого розвитку на міждисциплінарній та трансдисциплінарній основі, а також в контексті викладання конкретного предмету. Вони призначені для допомоги педагогам, які прагнуть включити знання, розуміння та інформацію у галузі стійкого розвитку в будь-яку навчальну програму. При цьому головна увага приділяється основам ефективного навчання та викладання, які застосовуються також і в галузі освіти для стійкого розвитку. 3 цією метою визначається ряд тем, що долають предметні кордони та відносяться до загальних цілей вищої освіти, а також до ії більш широкого соціального контексту.

Рекомендації включають в себе: визначення результатів навчання, тобто того, що студенти мають знати, розуміти і робити після відповідного періоду навчання, а також орієнтації щодо викладання, навчання та оцінювання, тобто того, як допомогти студентам у досягненні ними відповідних результатів і вмінні продемонструвати їх. 


\section{Освіта для стійкого розвитку як порядок денний}

Освіта $€$ вищим пріоритетом ЮНЕСКО, оскільки вона є одним з основних прав людини і основою для побудови світу і забезпечення стійкого розвитку. ЮНЕСКО $є$ спеціалізованою установою Організації Об'єднаних Націй у галузі освіти, а Сектор освіти забезпечує глобальне і регіональне лідерство у галузі освіти, зміцнює національні системи освіти і відповідає на сучасні глобальні виклики за допомогою освіти, приділяючи особливу увагу гендерній рівності.

ЮНЕСКО, як спеціалізованій установі Організації Об'єднаних Націй з освіти, доручено керувати і координувати Порядок денний у галузі освіти до 2030 року, яка є частиною глобального руху за викорінення злиднів за допомогою 17 цілей в області стійкого розвитку до 2030 року. Освіта, необхідна для досягнення всіх цих цілей має власну мету 4, яка спрямована на те, щоб забезпечити інклюзивну і справедливу якісну освіту і просувати можливості навчання протягом усього життя для всіх. Рамкова програма дій у галузі освіти до 2030 року являє собою керівництво для реалізації цієї амбітної мети і зобов'язань. Будучи провідним світовим освітнім агентством, ЮНЕСКО прагне просувати і стимулювати цю ключову інтелектуальну дискусію про майбутнє освіти.

Дані рекомендації сформульовані на основі аналізу документів міжнародних організацій та окремих інституціональних досліджень досвіду впровадження Освіти для стійкого розвитку (ESD - Education for Sustainable Development) на основі трансформативного навчання, яка дає учням можливість приймати усвідомлені рішення і проводити відповідальні заходи для забезпечення екологічної цілісності, економічної життєздатності і справедливого суспільного устрою для нинішнього і майбутніх поколінь при повазі культурного розмаїття. ESD сприяє цілісній і трансформативній освіті. Цей тип освіти стосується змісту і результатів навчання, інноваційної педагогіки і «навчання на практиці» («learning by doing») і використовує загальноінституціональний підхід для залучення спільнот в досягнення стійких змін.

ESD знаходиться у центрі Порядку денного у галузі стійкого розвитку на період до 2030 року і отримала широке визнання у якості ключового фактора стійкого розвитку і невід'ємного елементу якісної освіти. Він є частиною Цілі 4 в області стійкого розвитку, яка до 2030 року прагне забезпечити те, щоб всі учні придбали знання і навички, необхідні для сприяння стійкому розвитку, в тому числі за допомогою освіти для стійкого розвитку та стійкого способу життя, а також пронизує всі інші цілі у галузі стійкого розвитку (SDGs Sustainable Development Goals).

ЮНЕСКО є провідною установою в області Освіти для стійкого розвитку (ESD), що визнано в резолюції 70/209 Генеральної Асамблеї ООН 2015 року. У резолюції міститься заклик до Організації продовжувати забезпечувати координацію здійснення Глобальної програми дій (GAP - Global Action Programme) з Освіти для стійкого розвитку у співпраці з партнерами, виступати за виділення достатніх ресурсів для ESD; підтримувати держави-члени в нарощуванні потенціалу, сприяти обміну знаннями та передовим досвідом; і оцінити прогрес в досягненні ESD.

В якості лідера Десятиліття освіти для стійкого розвитку ООН (2005-2014рр.) Організація заклала основи для реалізації ESD у всьому світі. Великі партнерські відносини і мережі, а також тверді політичні зобов'язання, що сформувалися протягом Десятиліття, дозволили досягти широкого консенсусу щодо того, що якісна освіта в XXI столітті означає навчання тому, як жити і працювати стійко. Ця керівна роль була також визнана в декларації, прийнятій в 2014 році на Всесвітній конференції ЮНЕСКО по ОСР в Айті-Нагоя, Японія.

Глобальна програма дій (Global Action Programme (GAP)), яка $€$ продовженням Десятиліття, спрямована на вироблення і розширення масштабів дій в області ESD на всіх рівнях і у всіх областях освіти, професійної підготовки і навчання. Також зростає інтерес до міжнародної співпраці в рамках Цілей стійкого розвитку і Освіти для стійкого розвитку.

Освіта для стійкого розвитку (ESD) зазвичай розуміється як освіта, яка заохочує зміни в знаннях, навичках, цінностях і відносинах, щоб зробити суспільство більш стійким і справедливим для всіх. ESD спрямована на те, щоб розширити можливості і оснастити нинішнє і майбутні покоління для задоволення їх потреб, використовуючи збалансований і комплексний підхід до економічних, соціальних та екологічних аспектів стійкого розвитку.

Концепт Освіти для стійкого розвитку (ESD) народився з необхідності освіти для вирішення зростаючих екологічних проблем, що стоять перед планетою. Щоб зробити це, освіта має змінитися, щоб надати знання, навички, цінності та сформувати відносини, які дають учням можливість зробити свій внесок у стійкий розвиток. У той же час необхідно зміцнювати освіту в усіх програмах і заходах, що сприяють стійкому 
розвитку. Коротше кажучи, стійкий розвиток має бути інтегровано в освіту, а освіта повинна бути інтегрована в стійкий розвиток.

Термін «стійкий розвиток» має безліч різних тлумачень і визначень. В цілі Рекомендацій не входить докладне обговорення засад стійкого розвитку, позаяк вони вже були розглянуті та проаналізовані в Аналітичних матеріалах відділу інтернаціоналізації вищої освіти Інституту вищої освіти НАПН України за 2019 рік. В даних Рекомендаціях за основу приймається визначення, використане в доповіді Брундтланд «Наше спільне майбутнє» на Всесвітній Комісії ООН з Навколишнього середовища і Розвитку (1987 рік) ${ }^{1}$ : Стійкий розвиток - це розвиток, який відповідає потребам сьогодення, не ставлячи під загрозу здатність майбутніх поколінь задовольняти свої власні потреби. Всесвітній саміт Організації Об'єднаних Націй (2005 г.) $)^{2}$ підтримав концепцію трьох «стовпів» стійкості - економічного, соціального та екологічного чинників, які необхідно брати до уваги поряд 3 культурним контекстом. Зростає визнання того, що ці три чинники є взаємопов'язаними, частково співпадаючими і взаємозалежними, і, таким чином, виступають факторами збалансованості суспільного розвитку. Спираючись на визначення 1987 року і його уточнення 2005 року, а також подальші дослідження і рекомендації ЮНЕСКО в даних Рекомендаціях за основу визначення Освіти для стійкого розвитку приймається наступне: Освіта для стійкого розвитку - це процес навчання студентів і надбання ними ключових компетентностей, необхідних для роботи і життя таким чином, щоб гарантувати екологічний, соціальний і економічний добробут як в сьогоденні, так і в майбутньому поколінні. В контексті глобального розвитку сам процес такої освіти в дійсності стає процесом інтернаціоналізації та глокалізації. Таке розуміння на сьогодні має бути доповнено розробками ЮНЕСКО та членів Римського клубу щодо «стійкого розвитку» та «грамотності щодо майбутнього», які були здійснені в останнє десятиліття.

Освіта для стійкого розвитку є цілісною і трансформативною освітою і стосується змісту і результатів навчання, педагогіки і середовища навчання (UNESCO, 2014) ${ }^{3}$.

Що стосується змісту навчання, такого як навчальні програми, то складні проблеми стійкості, що стоять перед суспільством, перетинають кордони і численні тематичні області. Тому освіта має вирішувати ключові проблеми, такі як зміна клімату, бідність і забезпечити стійке виробництво. ESD сприяє інтеграції цих найважливіших питань стійкості в місцевому та глобальному контекстах в навчальну програму, щоб підготувати учнів до розуміння і реагування на мінливий світ. ESD націлена на отримання результатів навчання, які включають в себе основні компетентності, такі як критичне і системне мислення, спільне прийняття рішень і прийняття відповідальності за нинішнє і майбутні покоління.

Для того, щоб поставити та вирішувати такі різноманітні питання, ESD використовує інноваційну педагогіку, заохочуючи викладання та навчання інтерактивним, орієнтованим на навчання способом, що сприяє дослідницькому, орієнтованому на дії та трансформативному навчанню. Учні набувають здатність критично мислити і систематично розвивати цінності і підходи для стійкого майбутнього.

Оскільки традиційної односпрямованої передачі знань вже недостатньо, щоб спонукати учнів діяти як відповідальні громадяни, ESD включає в себе переосмислення навчального середовища, фізичного і віртуального. ESD має бути поширена на всі рівні формальної, неформальної та інформальної освіти як невід'ємну частину навчання протягом усього життя. Саме середовище навчання потрібно адаптувати і застосовувати загальноінституціональний підхід для впровадження філософії стійкого розвитку. Нарощування потенціалу викладачів і політична підтримка на міжнародному, регіональному, національному та місцевому рівнях допоможуть стимулювати ці зміни в навчальних закладах. Активна молодь і місцеві спільноти, які взаємодіють з освітніми установами, стають ключовими учасниками у просуванні стійкого розвитку.

Проведення Десятиліття освіти в інтересах стійкого розвитку ОOH (UN Decade of Education for Sustainable Development) (2005-2014рр.) викликало глобальний рух з переорієнтації освіти на вирішення проблем стійкого розвитку. Спираючись на досягнення Десятиліття, про які йдеться в Айті-Нагойській декларації по ESD, ЮНЕСКО схвалила Глобальну програму дій по ESD (Global Action Programme on ESD (GAP)) на 37-й сесії своєї Генеральної конференції. Визнана резолюцією Генеральної Асамблеї ОOH A/RES/69/211 (A/RES/69/211) і оголошена на Всесвітній конференції ЮНЕСКО з ESD в 2014 році, Глобальна програма дій

\footnotetext{
${ }^{1}$ Brundtland Report (1987) Our Common Future: Report of the World Commission on Environment and Development, United Nations. URL: www.un-documents.net/wced-ocf.htm

2 United Nations World Summit (2005) 2005 World Summit Outcome. URL:

www.un.org/en/ga/search/view doc.asp?symbol=A/RES/60/1

${ }^{3}$ UNESCO (2014) Shaping the Future We Want: UN Decade for Sustainable Development (2005-2014) Final Report. Paris: UNESCO. URL: http://unesdoc. unesco.org/images/0023/002301/230171e.pdf (accessed 28 January 2017)
} 
спрямована на розширення масштабів дій і передової практики. Будучи провідною установою Десятиліття $\mathrm{OOH} \mathrm{і} \mathrm{Глобальної} \mathrm{програми} \mathrm{дій,} \mathrm{ЮНЕСКО} \mathrm{разом} \mathrm{зі} \mathrm{своїми} \mathrm{партнерами} \mathrm{відіграє} \mathrm{важливу} \mathrm{роль} \mathrm{в} \mathrm{досягненні}$ ключових досягнень, спрямованих на те, щоб принципи ESD розвивалися за допомогою формальної, неформальної та інформальної освіти.

Міжнародне визнання ESD як ключового фактора стійкого розвитку неухильно зростає. Роль ESD була визнана на трьох основних самітах $\mathrm{OOH}$ зі стійкого розвитку: Конференції ООН з навколишнього середовища і розвитку (UNCED) 1992 року в Ріо-де-Жанейро, Бразилія; Всесвітньому саміті зі стійкого розвитку 2002 року (the 2002 World Summit on Sustainable Development (WSSD)) в Йоганнесбурзі, Південна Африка; і Конференції OOH зі стійкого розвитку 2012 року (the 2012 UN Conference on Sustainable Development (UNCSD)) в Piо-деЖанейро. Інші ключові глобальні угоди, такі як Паризька хартія (стаття 12) (the Paris Agreement (Article 12)), також визнають важливість ESD.

Сьогодні ОСР покладено в основу Порядку денного у галузі стійкого розвитку на період до 2030 року та його 17 цілей в галузі стійкого розвитку (Sustainable Development Goals (SDGs)) (United Nations, 2015). Цілі стійкого розвитку передбачають, що всі країни повинні стимулювати дії в таких ключових галузях, як люди, планета, процвітання, мир і партнерство для вирішення глобальних проблем, які мають вирішальне значення для виживання людства. Досягнення цих цілей вимагає глибоких перетворень у тому, як ми думаємо і діємо. 


\section{Що таке Освіта для стійкого розвитку: поява і розвиток концепту}

Освіта для стійкого розвитку має довгу історію і виникла в результаті глобальних дискусій, спрямованих на вирішення ключових проблем стійкості того часу. Автори видання «Проблеми і тенденції в освіті для стійкого розвитку» ${ }^{4}$, серед яких Александер Лайхт (A. Leicht), Джулія Хайс (J.Heiss), Вон Юнг Бюн (Won Jung Byun), Бернард Комбес (B. Combes), Адесува Ванесса Агбедахін (A. V. Agbedahin) розповідають про появу і розвиток концепту Освіти для стійкого розвитку. Автори виокремлюють два потоки змін: розробка Освіти для стійкого розвитку досліджується як з точки зору інтеграції стійкого розвитку в системи освіти, так і з точки зору того, як освіта була включена в дискурс стійкого розвитку. У ній розглядаються деякі міжнародні процеси, які сприяли появі Освіти для стійкого розвитку, і показано, як ці два потоки змін закладали міцну основу для такої освіти впродовж тривалого часу. Серед іншого, автори розглядають зростаючу центральну роль Освіти для стійкого розвитку в глобальному освітньому дискурсі, що відображено в Порядку денному в галузі освіти до 2030 року, а також актуальність освіти і, зокрема, Освіти для стійкого розвитку (ESD) в процесі досягнення всіх Цілей стійкого розвитку.

Концепт Освіти для стійкого розвитку розроблявся навколо ключових компетентностей і тем. Щоб зробити свій вклад у стійкий розвиток, люди повинні навчитися розуміти складність, невизначеність, ризики, пов'язані з глобальними і локальними проблемами стійкості, а також необхідність взаєморозуміння, співпраці та здатності до компромісів задля досягнення цілей стійкого розвитку. Вони повинні стати «громадянами стійкого розвитку».

Ухвалення Порядку денного у галузі стійкого розвитку на період до 2030 року дало новий імпульс освіті для стійкого розвитку (ESD) і створило дуже сприятливі умови для розширення масштабів імплементації ESD. 3 прийняттям Цілі 4 в області стійкого розвитку, яка спрямована на «забезпечення інклюзивної та справедливої якісної освіти і розширення можливостей для навчання протягом усього життя для всіх») (UN, 2015) цей порядок денний стає амбітною програмою загальної освіти. В рамках мети 4 визнається, що однією з найамбітніших, цікавих і складних цілей $є$ мета 4.7, яка спрямована на те, щоб: «До 2030 року забезпечити те, щоб всі учні здобували знання і навички, необхідні для сприяння стійкому розвитку, в тому числі за допомогою освіти для стійкого розвитку та стійкого способу життя, прав людини, гендерної рівності, заохочення культури миру і ненасильства, глобального громадянства, а також визнання культурного розмаїття і вкладу культури у стійкий розвиток» ${ }^{6}$.

Крім того, ESD може служити засобом для досягнення будь-яких цілей стійкого розвитку (Sustainable Development Goals (SDGs)). На підтримку цієї перспективи на своїй 74-й сесії Другий комітет Генеральної Асамблеї ООН прийняв резолюцію по ESD в рамках Цілей стійкого розвитку (A /C.2 / 72 /L.45), в якій була однозначно підтверджена роль Освіти для стійкого розвитку як «невід'ємного елемента Цілей стійкого розвитку в області якісної освіти та ключового фактора досягнення всіх інших цілей у галузі стійкого розвитку» ${ }^{7}$.

Сьогодні з позицій нинішніх сприятливих глобальних політичних умов для ESD, слід акцентувати на тому, що розвиток ESD відбувався за допомогою дослідження двох складових, які були однаково важливі для ESD: зусиль зацікавлених сторін з питань стійкого розвитку для використання освіти як інструменту досягнення стійкого розвитку, і зусиль зацікавлених сторін у галузі освіти для інтеграції принципів стійкого розвитку в системи освіти . Саме завдяки зближенню цих двох напрямків за ці роки з'явилася сильна підтримка ESD.

\footnotetext{
${ }^{4}$ Leicht, A.; Heiss, J.; Byun, W. J. (eds) (2018) Issues and trends in Education for Sustainable Development, UNESCO Publishing. URL: https://unesdoc.unesco.org/ark:/48223/pf0000261445

${ }^{5}$ United Nations (2015) 2030 Agenda for Sustainable Development and its 17 Sustainable Development Goals. URL: www.un.org/sustainabledevelopment

${ }^{6}$ United Nations (2015) 2030 Agenda for Sustainable Development and its 17 Sustainable Development Goals. URL: www.un.org/sustainabledevelopment

${ }^{7}$ United Nations (2015) The Millennium Development Goals Report, 2015. New York: United Nations. URL:

https://www.un.org/millenniumgoals/2015 MDG Report/pdf/MDG\%202015\%20rev\%20(July\%201).pdf

${ }^{8}$ Leicht, A.; Heiss, J.; Byun, W. J. (eds) (2018) Issues and trends in Education for Sustainable Development, UNESCO Publishing. URL: https://unesdoc.unesco.org/ark:/48223/pf0000261445
} 


\section{Інтеграція освіти у стійкий розвиток}

3 прийняттям Цілей стійкого розвитку (SDGs) роль освіти як інструменту в глобальних дискусіях з питань стійкого розвитку привернула до себе особливу увагу. Однак освіта як засіб досягнення стійкого розвитку не є новою ідеєю. Участь ЮНЕСКО у інформуванні та освіті в області навколишнього середовища відбувалася з самого початку Організації, коли в 1948 році був створений IUCN (International Union for the Conservation of Nature - Міжнародний союз охорони природи, нині Всесвітній союз охорони природи World Conservation Union), перша велика неурядова організація, уповноважена надавати допомогу в збереженні навколишнього середовища. ЮНЕСКО також брала активну участь у скликанні Міжнародної конференції ООН по навколишньому середовищу в Стокгольмі, Швеція, в 1972 році, яка привела до створення Програми Організації Об'єднаних Націй з навколишнього середовища (United Nations Environment Programme (UNEP)).

Слідом за цим протягом двох десятиліть ЮНЕСКО і ЮНЕП (UNEP) очолювали Міжнародну програму екологічної освіти (International Environmental Education Programme (1975-1995 роки)), в якій була сформульована концепція та надані практичні рекомендації щодо того, як мобілізувати освіту для підвищення обізнаності про навколишнє середовище. У 1976 році ЮНЕСКО випустила інформаційний бюлетень з екологічної освіти «Connect» у якості офіційного органу Міжнародної програми ЮНЕСКО-ЮНЕП 3 екологічної освіти (UNESCO-UNEP International Environmental Education Programme (IEEP)). Він служив інформаційним центром для обміну інформацією про екологічну освіту (Environmental Education (EE)) в цілому і для просування цілей і діяльності Міжнародної програми з екологічної освіти зокрема, а також у якості мережі для установ і окремих осіб, зацікавлених і тих, хто активно займався екологічною освітою аж до 2007 року.

Багаторічна співпраця між ЮНЕСКО і ЮHЕП (UNEP) в області екологічної освіти (а потім і ESD), починаючи з 1977 року, також призвела до спільної організації чотирьох великих міжнародних конференцій з екологічної освіти: першої міжурядової конференції з екологічної освіти в Тбілісі, Грузія, жовтень 1977 року (the First Intergovernmental Conference on Environmental Education in Tbilisi, Georgia, October 1977); конференції «Міжнародна стратегія дій в області екологічної освіти і навчання на 90-ті роки» в Москві, Російська Федерація, серпень 1987 року (the Conference «International Strategy for Action in the Field of Environmental Education and Training for the 1990s» in Moscow, Russian Federation, August 1987); третьої Міжнародної конференції «Навколишнє середовище та суспільство: освіта і підвищення обізнаності громадськості в інтересах стійкого розвитку» в Салоніках, Греція, грудень 1997 року (the Third International Conference «Environment and Society: Education and Public Awareness for Sustainability» at Thessaloniki, Greece, December 1997); і четвертої Міжнародної конференції з екологічної освіти на шляху до стійкого майбутнього в Ахмедабаді, Індія, листопад 2007 року (Fourth International Conference on Environmental Education towards a Sustainable Future in Ahmedabad, India, November 2007).

Ці зустрічі висвітили ключову роль освіти у стійкому розвитку. Саме на конференції в Тбілісі в 1977 році була повністю вивчена істотна роль освіти в питаннях навколишнього середовища. У Тбіліській декларації довкілля було визначено як «тотальність - природна і створена, технологічна і соціальна (економічна, політична, культурно-історична, етична, естетична)» ${ }^{9}$ (UNESCO, 1977, point 3). Цілі розвитку для екологічної освіти, у навчальній програмі виходять далеко за рамки екології та включають в себе розвиток «чіткого розуміння і заклопотаності економічною, соціальною, політичною та екологічною взаємозалежністю в міських і сільських районах» (там же, point 2), що стало однією з головних засад Освіти для стійкого розвитку.

Ця Декларація містила 41 рекомендацію, що охоплює три ключові області: роль, цілі та керівні принципи екологічної освіти; стратегії розвитку екологічної освіти на національному рівні; і міжнародне та регіональне співробітництво. Уряди зібралися разом, щоб домовитися про керівний принцип, згідно з яким екологічна освіта охоплює широкий спектр екологічних, соціальних, етичних і культурних аспектів. Однак це перспективне бачення так і не було реалізовано повністю: міжнародні та національні зусилля були зосереджені швидше на екологічних проблемах, ніж на комплексному гуманітарному, соціальному чи економічному розвитку.

\footnotetext{
${ }^{9}$ UNESCO (1977) Tbilisi Declaration. Intergovernmental Conference on Environmental Education. Tbilisi: UNESCO. URL: http://unesdoc.unesco.org/images/0003/000327/032763eo.pdf
} 
Проте, до четвертої конференції в Індії в 2007 році роль освіти у просуванні всіх трьох стовпів стійкого розвитку була широко визнана на міжнародному рівні. На цій зустрічі були розглянуті стан екологічної освіти і її розвиток для вирішення завдань у галузі стійкого розвитку, а також цілі Десятиліття освіти для стійкого розвитку ООН. У 2012 році, на зборах з нагоди 35-річчя глобальних зусиль у галузі освіти після першої Тбіліської конференції, Міжурядова конференція (Tibilisi + 35) ще раз підтвердила глобальний заклик до екологічної освіти як засобу досягнення стійкого розвитку.

У 1992 році в Ріо-де-Жанейро пройшов Саміт Землі (Earth Summit). На саміті був розроблений план дій «Порядок денний XXI століття» (Agenda 21). ЮНЕСКО була призначена Керівним органом для виконання завдань глави 36 порядку денного, що стосується освіти. У главі 36 Порядку денного на XXI століття чітко говориться, що сприяння освіті, інформування громадськості та підготовка кадрів пов'язані практично з усіма напрямками Порядку денного на XXI століття. Це ознаменувало важливу зміну в мисленні, пов'язаному 3 екологічною освітою, і початок об'єднання різних форм освіти (тобто, в області навколишнього середовища, народонаселення, розвитку іт. д.) в єдиний концепт Освіти для стійкого розвитку.

У 1994 році був запущений проект «Освіта в області навколишнього середовища і народонаселення, а також інформація про людський розвиток» (Environmental and Population Education and Information for Human Development project (EPD)). Цей проект був розроблений для досягнення «рівноправного і стійкого розвитку, орієнтованого на людину, за допомогою комплексного підходу до питань навколишнього середовища, народонаселення і розвитку» (UNESCO, 1994). У якості міждисциплінарного міжвідомчого проекту (зокрема, UNESCO, UNEP and UNFPA), в якому різні конкретні питання були об'єднані в єдиний об'єднуючий концепт Освіту для стійкого розвитку - EPD вийшов за рамки формального навчання і запропонував освіту по ряду каналів (школи, бізнес , ЗМІ, громадські організації та асоціації). Таким чином, EPD знаходилася в рамках загальної перспективи переорієнтації освіти або навіть реформи освіти в прямій відповідності з принципами безперервної освіти ${ }^{10}$.

Через двадцять років після Саміту в Ріо була проведена наступна конференція, Саміт Землі 2012 або Pio + 20 (Earth Summit 2012 or Rio+20). Конференція Організації Об'єднаних Націй з питань стійкого розвитку 2012 року підкреслила відданість урядів справі забезпечення стійкого розвитку шляхом сприяння Освіті стійкого розвитку відповідно до цілей Десятиліття (2005-2014 роки) (United Nations, 2012). При підготовці до цього саміту (і в ході подальших політичних дискусій) росло розуміння того, що, як відзначала ЮНЕСКО в своєму основному вихідному документі для саміту, «Стійкий розвиток не може бути досягнуто за допомогою технологічних рішень, політичного регулювання або фінансових інструментів. Досягнення стійкого розвитку вимагає зміни у тому, як ми думаємо і діємо, і, отже, переходу до стійкого способу життя, відповідних моделей споживання і виробництва. Тільки освіта і навчання на всіх рівнях і у всіх соціальних контекстах може привести до цих критично важливих змін» ${ }^{11}$ (UNESCO, 2012: 13). Згодом Підсумковий документ «Piо + 20» «Майбутнє, якого ми хочемо» (The Future We Want) включав в себе тверді зобов'язання щодо освіти як важливої для зеленої економіки, для роботи і соціального захисту, а також для стійкості в цілому.

З 2012 року роль Освіти для стійкого розвитку отримала подальше визнання в ході глобальних консультацій, організованих Організацією Об'єднаних Націй по ряду конкретних тем, в яких підбиваються підсумки досягнення цілей в області розвитку, сформульованих в Декларації тисячоліття, і в рамках підготовки Цілей стійкого розвитку (GSDs). Питання, які розглядалися в ході однієї з цих консультацій, включали в себе екологічну стійкість і ряд конкретних екологічних проблем. Хоча учасниками цієі консультації були в основному представники сектора навколишнього середовища, а не сектора освіти, освіту було виділено у якості одного з найбільш важливих факторів змін. Як наголошується у звіті про консультації, «Освіта вважається одним з найбільш потужних інструментів, що сприяють трансформаційним змінам, необхідним для стійкого розвитку, але для реалізації цього потенціалу системи освіти повинні бути гнучкими, культурно чутливими, релевантними і придатними для зміни цінностей і поведінки людей» (World We Want, 2013: iv) ${ }^{12}$. Ця теза також ясно акцентує, що для того, щоб стати рушійною силою змін, сама освіта повинна змінитися, стати трансформативною, змінити цінності і поведінку.

\footnotetext{
${ }^{10}$ Leicht, A.; Combes, B; Byun, W.J.; Agbedahin, A.V. (2018) From Agenda 21 to Target 4.7: the development of Education for Sustainable Development. In: Leicht, A.; Heiss, J.; Byun, W. J. (eds) (2018) Issues and trends in Education for Sustainable Development, UNESCO Publishing. URL: https://unesdoc.unesco.org/ark:/48223/pf0000261445

${ }^{11}$ UNESCO (2012) From Green Economies to Green Societies:. UNESCO's Commitment to Sustainable Development. URL: https://www.greengrowthknowledge.org/sites/default/files/downloads/resource/Green_Economy_UNESCO.pdf

${ }^{12}$ The World We Want (2013) Breaking down the Silos: Integrating Environmental Sustainability in the Post-2015 Agenda. URL: http://www.worldwewant2015.org/sustainability
} 
Напередодні прийняття Цілей стійкого розвитку (SDGs) в 2015 році були проведені різні дискусії про важливість освіти для досягнення стійкого розвитку. На одному з найбільш важливих етапів цього процесу міжурядових консультацій в рамках Відкритої Робочої Групи по Цілям стійкого розвитку (SDGs), була обговорена тема ролі освіти в досягненні стійкого розвитку. Генеральний секретар ООН представив представникам держав-членів ООН результати анкетування, що стосуються ключових елементів порядку денного в галузі стійкого розвитку, в якості початкового внеску для обговорення в рамках Відкритої Робочої Групи. Освіта увійшла в четвірку першочергових факторів стійкого розвитку (після їжі, води та енергії) (United Nations General Assembly, 2012). У звіті про роботу Відкритої Робочої Групи Генеральної Асамблеї ООН у 2013 році йдеться: «Освіта являється абсолютно першочерговим питанням для будь-якого порядку денного у галузі стійкого розвитку» (United Nations General Assembly, 2013) ${ }^{13}$.

У своєму резюме до четвертої сесії групи, присвяченій освіті, співголови говорили про важливість освіти для «трансформативних зрушень, необхідних для стійкого розвитку», і підкреслювали, що «цілісна освіта може формувати суспільні цінності, які підтримують стійкий розвиток» (Open Working Group, 2013$)^{14}$. Ці ключові дискусії про роль освіти для успіху Цілей стійкого розвитку (SDGs) привели до створення єдиної мети - Цілі стійкого розвитку 4, присвяченій освіті та інтеграції освіти в інші цілі розвитку для підтримки їх досягнення (UNESCO, 2013а) ${ }^{15}$. Всесвітня асоціація профспілок вчителів (Education International), повторила це в документі з викладенням своєї позиції по освіті після 2015 року: якісна освіта має основоположне значення для досягнення всіх інших цілей розвитку, включаючи гендерну рівність, здоров'я, харчування і стійкість навколишнього середовища (Education International)16. Виданий в 2013-2014 рр. Звіт про глобальний моніторинг «Освіта для всіх» (Education for All Global Monitoring Report) переконливо свідчить про те, що «освіта трансформує життя» за допомогою навчання трансферабельним навичкам, необхідним для глобального громадянства, і зміни поглядів і поведінки, необхідних для пом'якшення кліматичних змін і адаптації до них (UNESCO, 2014) ${ }^{17}$.

У 2016 році в Звіті про моніторинг Глобальної Освіти (GEM - Global Education Monitoring Report) наголошувалося на важливості освіти для досягнення всіх Цілей стійкого розвитку протягом наступних п'ятнадцяти років. «Цілі, завдання та засоби реалізації розглядаються як універсальні, неподільні і взаємозалежні. Кожна з 17 цілей має свої завдання. У кожній групі завдань щонайменше одна задача включає в себе навчання, тренінг, освіту або, у крайньому випадку, підвищення обізнаності про основні проблеми стійкого розвитку. Освіта вже давно визнана найважливішим фактором у справі вирішення проблем навколишнього середовища і стійкості і забезпечення добробуту людей» (UNESCO, 2016) ${ }^{18}$.

У звіті підкреслюється гостра необхідність у нових підходах, важливість довгострокових зобов'язань щодо Цілі стійкого розвитку 4 і необхідність радикальних змін для того, щоб розуміти освіту як силу для досягнення добробуту людей і глобального розвитку (UNESCO, 2016). Це говорить про те, що потенціал освіти для трансформації нашого світу не може бути реалізований, якщо системи освіти не включатимуть в себе стійкий розвиток.

${ }^{13}$ United Nations General Assembly (2013) Progress report of the Open Working Group of the General Assembly on Sustainable Development Goals. URL: http://www.un.org/ga/search/view doc.asp?symbol=A/67/941\&Lang=E

${ }^{14}$ Open Working Group on Sustainable Development Goals (2013) Concluding Remarks of Co-Chairs, OWG4, 19 June 2013. URL: http://sustainabledevelopment.un.org/content/documents/3693cochairsconcluding.pdf

${ }^{15}$ UNESCO (2013) Concept note on the post-2015 education agenda. URL: http://www.unesco.org/new/fileadmin/MULTIMEDIA/HQ/ED/ED new/pdf/UNESCOConceptNotePost2015 ENG.pdf

${ }^{16}$ UNESCO (2014) Global Citizenship Education: Preparing learners for the challenges of the 21stcentury. Paris: UNESCO. URL: http://www.eunec.eu/sites/www.eunec.eu/files/attachment/files/global_citizenship_education_report..pdf

${ }^{17}$ UNESCO (2014) Teaching and Learning: Achieving Quality for All. EFA Global Monitoring Report 2013-2014. Paris: UNESCO. URL: https://unesdoc.unesco.org/ark:/48223/pf0000225660

${ }^{18}$ UNESCO (2016) Global Education Monitoring Report - Education for People and Planet: Creating Sustainable Futures for All. Paris: UNESCO. URL: https://unesdoc.unesco.org/ark:/48223/pf0000245752 
Цілі стійкого розвитку та можлива роль освіти для їх досягнення

\begin{tabular}{|c|c|}
\hline 1 & $\begin{array}{l}\text { бідності - кінець бідності (No Poverty - End poverty) у всіх її формах і всюди. } \\
\text { віта має вирішальне значення для виведення людей з бідності. }\end{array}$ \\
\hline 2 & $\begin{array}{l}\text { Нульовий голод - кінець голоду (Zero Hunger - End Hunger), досягнення продовольчої безпеки, поліпшення харчування } \\
\text { та сприяння сталому сільському господарству. } \\
\text { Освіта відіграє ключову роль у допомозі людям для переходу до більш стійких методів ведення сільського } \\
\text { господарства і для розуміння питань харчування. }\end{array}$ \\
\hline 3 & $\begin{array}{l}\text { Добре здоров'я і добробут (Good Health and Well-Being) - забезпечення здорового способу життя та сприяння } \\
\text { добробуту для всіх у будь-якому віці. } \\
\text { Освіта може мати вирішальне значення для цілого ряду проблем охорони здоров'я, включаючи ранню смертність, } \\
\text { репродуктивне здоров'я, поширення хвороб, здоровий спосіб життя і благополуччя. }\end{array}$ \\
\hline 4 & $\begin{array}{l}\text { Якісна освіта (Quality Education) - забезпечення інклюзивної та справедливої якісної освіти і сприяння можливостям } \\
\text { безперервного навчання для всіх. } \\
\text { Якісна освіта постає саме як Освіта для стійкого розвитку. }\end{array}$ \\
\hline 5 & $\begin{array}{l}\text { Гендерна рівність (Gender Equality) - досягнення ґендерної рівності та розширення прав жінок і дівчат. } \\
\text { Освіта для жінок і дівчаток особливо важлива для досягнення базової грамотності, поліпшення навичок і здібностей їх } \\
\text { участі в житті суспільства і підвищення їх життєвих шансів. }\end{array}$ \\
\hline 6 & $\begin{array}{l}\text { Чиста вода і санітарія (Clean Water and Sanitation) - забезпечення доступності та збалансованого розпорядження } \\
\text { водою і санітарією для всіх. } \\
\text { Освіта і професійна підготовка підвищують навички і здатність більш раціонально використовувати природні ресурси і } \\
\text { можуть сприяти гігієні. }\end{array}$ \\
\hline 7 & $\begin{array}{l}\text { Доступна і чиста енергія (Affordable and Clean Energy) - забезпечення доступу до доступної, надійної і чистої енергії для } \\
\text { всіх. } \\
\text { Освітні програми, зокрема неформальні і інформальні, можуть сприяти кращому енергозбереженню та освоєнню } \\
\text { відновлюваних джерел енергії. }\end{array}$ \\
\hline 8 & $\begin{array}{l}\text { Гідна праця і економічне зростання (Decent Work and Economic Growth) - сприяння стабільному, інклюзивному та } \\
\text { стійкому зростанню, повній і продуктивній зайнятості та гідній роботі для всіх. } \\
\text { Існує прямий зв'язок між такими сферами, як економічна життєздатність, підприємництво, навички ринку праці і рівні } \\
\text { освіти. }\end{array}$ \\
\hline 9 & $\begin{array}{l}\text { Індустрія, інновації та інфраструктура (Industry, Innovation and Infrastructure) - створення гнучкої інфраструктури, } \\
\text { сприяння стійкій індустріалізації і стимулювання інновацій. } \\
\text { Освіта необхідна для розвитку навичок, необхідних для створення більш стійкої інфраструктури і більш стійкої } \\
\text { індустріалізації. }\end{array}$ \\
\hline 10 & $\begin{array}{l}\text { Зменшення нерівності (Reduced Inequalities) - зменшення нерівності у межах країн і між країнами. } \\
\text { В рівній мірі доступна освіта дозволяє побачити відмінності, які проявляються в соціальній і економічній нерівності. }\end{array}$ \\
\hline 11 & $\begin{array}{l}\text { Стійкі міста і спільноти (Sustainable Cities and Communities) - зробити міста і населені пункти інклюзивними, } \\
\text { безпечними, гнучкими і стійкими. } \\
\text { Освіта може дати людям навички участі у формуванні та підтримці більш стійких міст і досягненні стабільності в } \\
\text { ситуаціях лих. }\end{array}$ \\
\hline 12 & $\begin{array}{l}\text { Відповідальне споживання і виробництво (Responsible Consumption and Production) - забезпечення стійких моделей } \\
\text { споживання і виробництва. } \\
\text { Освіта може мати вирішальне значення для моделей виробництва (наприклад, щодо економіки замкнутого циклу) і } \\
\text { розуміння споживачами більш стійко вироблених товарів і використання відходів. }\end{array}$ \\
\hline 13 & $\begin{array}{l}\text { Кліматичні дії (Climate Action) - вжити термінових заходів для боротьби зі змінами клімату та їх наслідками. } \\
\text { Освіта є ключем до масового розуміння впливу зміни клімату та до адаптації і пом'якшення кліматичних змін, зокрема } \\
\text { на місцевому рівні. }\end{array}$ \\
\hline 14 & $\begin{array}{l}\text { Життя у воді (Life below Water) - збереження і стале використання океанів, морів і морських ресурсів для стійкого } \\
\text { розвитку. } \\
\text { Освіта відіграє важливу роль у підвищенні обізнаності про морське середовище і формування активного консенсусу } \\
\text { щодо його розумного і невиснажливого використання. }\end{array}$ \\
\hline 15 & $\begin{array}{l}\text { Життя на суші (Life on Land) - захист, відновлення та сприяння стійкому використанню наземних екосистем, стійке розпорядження } \\
\text { лісами, боротьба з опустелюванням, припинення деградації земельі їх рекультивація, припинення втрати біорізноманітяя. } \\
\text { Освіта і професійна підготовка підвищують навички і здатність підтримувати стійкі джерела засобів до існування і } \\
\text { зберігання природних ресурсів і біорізноманітя, зокрема в середовищі, яке перебуває під загрозою. }\end{array}$ \\
\hline 16 & $\begin{array}{l}\text { Мир, справедливість і сильні інститути (Реace, Justice and Strong Institutions) - сприяння мирним та інклюзивним } \\
\text { товариствам для стійкого розвитку, надання доступу до правосуддя для всіх і створення ефективних, підзвітних та } \\
\text { інклюзивних інститутів на всіх рівнях. } \\
\text { Соціальне навчання життєво важливо для полегшення і забезпечення участі в житті суспільства, для досягнення } \\
\text { інклюзивного та справедливого суспільства, а також соціальної злагоди. }\end{array}$ \\
\hline 17 & $\begin{array}{l}\text { Партнерство для досягнення цілей (Partnerships for the Goals) - зміцнення засобів імплементації та активізації } \\
\text { глобального партнерства в ім'я стійкого розвитку }{ }^{19} \text {. } \\
\text { Навчання протягом усього життя дає можливість розуміти і просувати політику і практику стійкого розвитку. }\end{array}$ \\
\hline
\end{tabular}

${ }^{19}$ Джерело: ICSU and ISSC (2015) URL: http://www.un.org/sustainabledevelopment/sustainabledevelopment-goals 
На сьогоднішній день Освіта для стійкого розвитку інтегрована в численні глобальні документи і конвенції з ключових тем стійкого розвитку. Наприклад, в статті 13 Конвенції про біологічне різноманіття (Convention on Biological Diversity) і в програми її роботи; в Хіогську програму дій на 2005-2015 роки (Нуоgо Framework for Action 2005-2015): побудова стійкості країн і спільнот до катастроф (Building the Resilience of Nations and Communities to Disasters) і подальшу Сендайську програму зі зменшення небезпеки лих на 20152030 роки (Sendai Framework for Disaster Risk Reduction 2015-2030); в програму зі стійкого способу життя і 10річну програму зі стійкого споживання та виробництва на 2012-2021 роки (Sustainable Lifestyles and Education Programme of the 10-Year Framework of Programmes on Sustainable Consumption and Production 2012-20); до статті 6 Конвенції Організації Об'єднаних Націй про зміну клімату (United Nations Framework Convention on Climate Change) та в статті 11 і 12 Паризького угоди (Paris Agreement Issues and Trends in Education for Sustainable Development). 


\section{Інтеграція стійкого розвитку в освіту}

Загальна політична підтримка Освіти для стійкого розвитку також є результатом підвищеної уваги з боку зацікавлених сторін у галузі освіти, що вирішують питання щодо підвищення кваліфікації. Це корелюється з громадською тенденцією виходу за рамки простої уваги до доступу до освіти та базової навички та переключення уваги на релевантний навчальний контент, що відповідає на сучасні виклики.

Багато років в центрі уваги до глобального розвитку освіти знаходилося забезпечення базової освіти для всіх. Мета 2 в області розвитку, сформульована в Декларації тисячоліття Організації Об'єднаних Націй, що стосується загальної початкової освіти і руху «Освіта для всіх» (Education for All movement) (2000-2015 роки), була спрямована на досягнення цієї мети (UN, 2015) ${ }^{20}$. Виходячи з принципу, згідно з яким освіта є основним і невід'ємним правом людини, підтвердженим в ключових міжнародних угодах, таких як Загальна декларація прав людини (Universal Declaration of Human Rights), доступ до базової грамотності і вмінню рахувати був у центрі міжнародних зусиль у галузі освіти і буде як і раніше мати вирішальне значення.

Проте, в усе більш складному і взаємопов'язаному світі з дуже реальною екзистенційною загрозою, такою як зміна клімату, зростає попит на освіту, яка виходить за рамки простого набуття знань і навичок для пошуку роботи. Стало ясно не тільки те, що освіта $\epsilon$ інструментом стійкого розвитку, а й те, що сама концепція і практика викладання та навчання мають бути трансформовані так, щоб дати можливість людям прийти до стійкого розвитку в якості агентів змін. Більш ранні роздуми з цього приводу можна простежити аж до мети 6 Дакарської Програми дій у галузі освіти для всіх (2000) (Dakar Framework for Action on Education for All (2000) - EFA), що стосується поліпшення всіх аспектів якісної освіти (UNESCO, 2000) ${ }^{21}$.

Зобов'язання щодо EFA (Education Framework for Action) визначили важливі зв'язки з порядком денним Освіти для стійкого розвитку, зокрема підкріплені Всесвітньою зустріччю на вищому рівні зі стійкого розвитку 2002 року. Оскільки обговорення на вищому рівні 2002 року призвели до початку Десятиліття освіти в інтересах стійкого розвитку ООН (2005-2014), переорієнтація існуючих освітніх програм з метою забезпечення стійкості була названа одним із чотирьох основних напрямків Освіти для стійкого розвитку (UNESCO, 2005) 22. Сьогодні стає зрозуміло, що зв'язки між EFA (Education Framework for Action) i ESD включають в себе прагнення до якісної освіти; розуміння освіти як права кожної людини; і просування якості життя через освіту. Більш того, перехід до питань якості, актуальності та змісту навчання став більш очевидним (UNESCO, 2008) ${ }^{23}$.

Як говориться в документі ЮНЕСКО, представленому на ії Генеральній конференції в 2013 році: ЮНЕСКО підтверджує гуманістичне і цілісне бачення освіти як основоположної для особистого і соціальноекономічного розвитку. Мета такої освіти повинна розглядатися в широкій перспективі, яка спрямована на те, щоб озброїти людей, забезпечити їм можливості для задоволення їх основних індивідуальних потреб, задоволення їх особистих очікувань і сприяння досягненню цілей соціально-економічного розвитку їх спільнот і країн (UNESCO 2013) 24.

Одним із ключових індикаторів переходу до більш релевантного освітнього контенту стала Перша Ініціатива Глобальної Освіти (Global Education First Initiative), висунута Генеральним секретарем ООН в 2012 році. Ця ініціатива включала в себе три пріоритети - навчання кожної дитини у школі, підвищення якості навчання і розвиток глобального громадянства, - і включала тезу про те, що «доступ до освіти має

${ }^{20}$ United Nations (2015) The Millennium Development Goals Report, 2015. New York: United Nations. URL:

https://www.un.org/millenniumgoals/2015_MDG_Report/pdf/MDG\%202015\%20rev\%20(July\%201).pdf

${ }^{21}$ UNESCO (2000) The Dakar Framework for Action. Education for All: Meeting our Collective Commitments. The World Education Forum. Dakar: UNESCO, 17. URL:

https://sustainabledevelopment.un.org/content/documents/1681Dakar\%20Framework\%20for\%20Action.pdf

${ }^{22}$ UNESCO (2005) United Nations Decade of Education for Sustainable Development (2005-2014): International Implementation Scheme. Paris, UNESCO. URL: https://unesdoc.unesco.org/ark:/48223/pf0000148654

${ }^{23}$ UNESCO (2008) EFA-ESD Dialogue: Educating for a sustainable world. Paris, UNESCO. URL: https://unesdoc.unesco.org/ark:/48223/pf0000178044

${ }^{24}$ UNESCO (2013) Concept note on the post-2015 education agenda. URL: http://www.unesco.org/new/fileadmin/MULTIMEDIA/HO/ED/ED new/pdf/UNESCOConceptNotePost2015 ENG.pdf 
вирішальне значення. Але цього не достатньо» (UNESCO 2013b)25. В рамках реалізації цієї ініціативи ЮНЕСКО розробила план освіти, що сприяє глобальному громадянству (UNESCO, 2014) ${ }^{26}$.

Одним із прикладів підвищеної інтересу до релевантного контенту освіти є увага, яка приділяється трансферабельним, або трансверсальним навичкам. Наприклад, Цільова група за показниками навчання (Learning Metrics Task Force), глобальна консультативна група, створена Інститутом Брукінгса (Brookings Institution) та Інститутом статистики ЮНЕСКО (Institute of Statistics) в 2015 році, говорить про необхідність «адаптивного, гнучкого ряду навичок, що відповідають вимогам 21-го столітяя (Learning Metrics Task Force, $2013)^{27}$. Згідно зі звітом Цільової групи такі навички можуть включати в себе поряд з очевидними, такими як оволодіння інформаційними і комунікаційними технологіями, нові навички, такі як «спільне рішення проблем». Іншим обнадійливим прикладом уваги, що приділяється трансверсальним навичкам, $\epsilon$ дослідження, проведене ОЕCD по соціально-емоційним навичкам (OECD, 2015) ${ }^{28}$, і Програма навчання «Освіта 2030» (Education 2030 Learning Framework) (OECD, 2016) ${ }^{29}$. Фактичні дані показують зростаючу тенденцію руху від питань базового доступу до освіти до акценту на соціально-емоційні навички для досягнення позитивних результатів у житті і скорочення освітнього і соціального диспаритету, що дуже добре узгоджується із загальною метою досягнення стійкого розвитку.

У 2015 році на 70-й сесії Генеральної Асамблеї ООН держави-члени прийняли новий глобальний порядок денний у галузі розвитку, який має назву «Перетворення нашого світу: Порядок денний у галузі стійкого розвитку на період до 2030 року (Цілі стійкого розвитку)» (Transforming our World: the 2030 Agenda for Sustainable Development (Sustainable Development Goals) $)^{30}$. Цілі стійкого розвитку (SDGs) були розроблені для заміни цілей розвитку, сформульованих в Цілях розвитку на Тисячоліття (Millennium Development Goals (MDGs)), та ряду глобальних, регіональних і національних цілей з чіткою орієнтацією на досягнення стійкості. Хоча в досягненні Цілей розвитку на Тисячоліття (MDGs) було досягнуто значного прогресу, вони були різними у залежності від конкретного регіону, країни і цілі (Sachs, 2012) $)^{31}$. Досвід і уроки, отримані в ході реалізації Цілей розвитку на Тисячоліття (MDGs), були використані державами-членами ООН і послужили основою для порядку денного у галузі розвитку на період після 2015 року і Цілей стійкого розвитку (SDGs). Ухвалення окремої мети у галузі освіти - Цілі стійкого розвитку 4, підтвердило вирішальну роль освіти у прискоренні прогресу на шляху до стійкого розвитку. В Інчхонській декларації щодо «Освіти 2030» (Incheon Declaration on Education 2030) говориться: «Наше бачення полягає у тому, щоб перетворити життя за допомогою освіти, визнаючи важливу роль освіти у якості основної рушійної сили розвитку і в досягненні інших Цілей стійкого розвитку» (The Incheon Declaration, 2015) ${ }^{32}$.

Завдання Цілей стійкого розвитку $4 \in$ проявом зсуву в бік якості, актуальності та змісту освіти. Отже, поряд з тим, що Інчхонська декларація підтвердила те, що Ціль стійкого розвитку 4 натхненна гуманістичним баченням освіти і розвитку, в ній чітко визначено, що ключовою частиною якісної освіти є Освіта для стійкого розвитку (ESD): Якісна освіта сприяє креативності та пізнанню, забезпечує придбання основоположних навичок грамотності та рахунку, а також аналітичних навичок, навичок вирішення проблем та інших когнітивних, міжособистісних і соціальних навичок високого рівня. Вона також розвиває навички, цінності та підходи, які дозволяють громадянам вести здорове і повноцінне життя, приймати обґрунтовані рішення і

\footnotetext{
${ }^{25}$ UNESCO (2013) Global Citizenship Education: An Emerging Perspective. URL: http://unesdoc.unesco.org/images/0022/002241/224115E.pdf

${ }^{26}$ UNESCO (2013) Global Citizenship Education: An Emerging Perspective. URL: http://unesdoc.unesco.org/images/0022/002241/224115E.pdf

${ }^{27}$ Learning Metrics Task Force (2013) Executive Summary. Toward Universal Learning: A Global Framework for Measuring Learning. Montreal and Washington, DC: UNESCO Institute for Statistics and Center for Universal Education at the Brookings Institution. URL: https://www.brookings.edu/wp-ontent/uploads/2016/06/LMTFReport2ES final.pdf

${ }^{28}$ OECD (2015) Skills for Social Progress: The Power of Social and Emotional Skills. Paris. OECD. URL:

https://www.oecd.org/education/skills-for-social-progress-9789264226159-en.htm

${ }^{29}$ OECD (2016) The Education 2030 Conceptual learning framework as a tool to build common understanding of complex concepts, $4^{\text {th }}$ Informal working Group on the Future of Education and skills: OECD Education 2030, Beijing, 2016. URL:

http://www.oecd.org/education/2030-project/contact/OECD_Learning_Compass_2030_Concept_Note_Series.pdf

30 United Nations (2015) 2030 Agenda for Sustainable Development and its 17 Sustainable Development Goals. URL: www.un.org/sustainabledevelopment

${ }^{31}$ Sachs, J.D. (2012) From Millennium Development Goals to Sustainable Development Goals. Lancet, 379: 2206-2211.

32 Leicht, A.; Combes, B; Byun, W.J.; Agbedahin, A.V. (2018) From Agenda 21 to Target 4.7: the development of Education for Sustainable Development. In: Leicht, A.; Heiss, J.; Byun, W. J. (eds) (2018) Issues and trends in Education for Sustainable Development, UNESCO Publishing. URL: https://unesdoc.unesco.org/ark:/48223/pf0000261445
} 
реагувати на місцеві та глобальні виклики за допомогою Освіти для стійкого розвитку OCP(ESD) і Освіти в області глобального громадянства (Global Citizenship Education (GCED).

У зв'язку з цим українські освітяни мали б рішуче підтримати реалізацію Глобальної програми дій в області Освіти для стійкого розвитку (Global Action Programme on ESD), яка була прийнята на Всесвітній конференції ЮНЕСКО по Освіті для стійкого розвитку в Айті-Нагоя в 2014 році (UNESCO World Conference on ESD in Aichi-Nagoya in 2014). Слід також наголосити на важливості освіти і підготовки в області прав людини для виконання порядку денного в галузі стійкого розвитку на період після 2015 року (World Education Forum, 2015: para. 9). 


\section{Глобальна програма дій в області Освіти для стійкого розвитку (GAP on ESD)}

Коріння Освіти для стійкого розвитку (ESD) знаходяться у двох розглянутих вище процесах: інтеграції освіти в стійкий розвиток та стійкого розвитку в освіту. Основна мета Десятиліття ООН у галузі освіти для стійкого розвитку (2005-2014 роки) (UN Decade of Education for Sustainable Development (2005-2014, DESD)) була викладена в резолюції 59/237 Генеральної Асамблеї ООН, в якій Генеральна Асамблея визнала узгоджену на міжнародному рівні мету розвитку, яка полягає в досягненні загальної початкової освіти. Вона також привітала той факт, що Комісія зі стійкого розвитку на своїй одинадцятій сесії визначила освіту в якості одного з наскрізних питань своєї розрахованої на багаторічну перспективу програми робіт, і таким чином підтвердила, що освіта в інтересах стійкого розвитку має вирішальне значення для сприяння стійкому розвитку (UNESCO, 2005) ${ }^{33}$.

Освіта для стійкого розвитку (ESD) розуміється як освіта, яка дозволяє кожній людині здобувати знання, навички, погляди і цінності, необхідні для формування стійкого майбутнього. Серед іншого це означає включення ключових питань стійкого розвитку у викладання і навчання; до них відносяться, наприклад, зміна клімату, зниження ризику катастроф, біорізноманіття, скорочення бідності і стійке споживання. ESD також вимагає активних методів викладання і навчання, які мотивують і дають учням можливість змінити свою поведінку і вжити заходів для стійкого розвитку (UNECE, 2011) $)^{34}$. Отже, Освіта для стійкого розвитку сприяє розвитку таких компетентностей, як критичне мислення, прогноз сценаріїв майбутнього і прийняття рішень на основі співпраці (UNESCO, 2011) $)^{35}$. Освіта для стійкого розвитку (ESD) $€$ динамічним концептом і терміном, що включає в себе нове бачення освіти, яка прагне дати людям будьякого віку особисту відповідальність за створення стійкого майбутнього (UNESCO, 2005, 2014а) ${ }^{36}$. Це інтердисциплінарний і трансдисциплінарний проект, який означає, що жодна дисципліна не може претендувати на Освіту для стійкого розвитку (ESD) як на свою власність, але всі дисципліни можуть реагувати і вносити свій вклад в ESD індивідуально або колективно.

Всі основні міжнародні конференції з розвитку 1990-х років, а саме: Саміт Землі 1992 року (Earth Summit 1992); Каїрська конференція з народонаселення та розвитку 1994 року (Сairo Conference on Population and Development 1994), Всесвітній саміт на вищому рівні в інтересах соціального розвитку 1995 року (World Summit for Social Development 1995), Четверта Всесвітня конференція зі становища жінок 1995 року (Fourth World Conference on Women 1995), Друга конференція ООН з питань людського врегулювання 1996 роки (Second UN Conference on Human Settlement 1996) визнали і підкреслили здатність освіти формувати відносини, цінності і поведінку, розвивати здібності та навички, а також формувати розуміння і прихильність цілям розвитку. У Хартії Землі, наприклад, підкреслюється, що заклик громадянського суспільства до стійкості включає в себе загальний принцип інтеграції у формальну освіту і навчання протягом усього життя знань, цінностей і навичок, необхідних для стійкого способу життя (Earth Charter, 2000).

Всесвітній Саміт з питань Стійкого Розвитку в Йоганнесбурзі 2002 року (Johannesburg World Summit on Sustainable Development (WSSD)) рекомендував для реалізації своїх рішень Освіту для стійкого розвитку (ESD) у якості ключового концепту, таким чином підкресливши важливу роль освіти в стійкий розвиток. План виконання рішень WSSD припускав, що концепти, дії і принципи стійкого розвитку повинні бути інтегровані в усі рівні освіти, щоб сприяти перетворенню освіти на ключовий фактор змін (United Nations, 2002).

У розвиток цього плану Генеральна Асамблея Організації Об'єднаних Націй прийняла в грудні 2002 року резолюцію ООН 57/254, в якій 2005-2014 роки були названі Десятиліттям освіти в інтересах стійкого розвитку Організації Об'єднаних Націй (United Nations Decade of Education for Sustainable Development (UNDESD)) (UN, 2002). Загальна мета Десятилітя полягала у тому, щоб інтегрувати принципи, цінності та

\footnotetext{
${ }^{33}$ UNESCO (2005) United Nations Decade of Education for Sustainable Development (2005-2014): International Implementation Scheme. Paris, UNESCO. URL: https://unesdoc.unesco.org/ark:/48223/pf0000148654

34 UNECE (2011) Learning for the future: Competences in Education for Sustainable Development. URL: http://www.unece.org/fileadmin/DAM/env/esd/6thMeetSC/Learning\%20for\%20the\%20Future_\%20Competences\%20for\%20Educators\%20i n\%20ESD/ECE_CEP_AC13 2011_6\%20COMPETENCES\%20EN.pdf

${ }^{35}$ UNESCO (2011) ESD: Education for Sustainable Development - building a better, fairer world for the $21^{\text {st }}$ century. URL: https://unesdoc.unesco.org/ark:/48223/pf0000216673

${ }^{36}$ UNESCO (2005) United Nations Decade of Education for Sustainable Development (2005-2014): International Implementation Scheme. Paris, UNESCO. URL: https://unesdoc.unesco.org/ark:/48223/pf0000148654;

UNESCO (2014a) Global Citizenship Education: Preparing learners for the challenges of the 21stcentury. Paris: UNESCO. URL: http://www.eunec.eu/sites/www.eunec.eu/files/attachment/files/global citizenship education report..pdf
} 
практику стійкого розвитку в усі аспекти освіти та навчання, а також заохочувати зміни в знаннях, цінностях і підходах з метою створення більш стійкого і справедливого суспільства для всіх (UNESCO, 2005, 2014a, $2014 b)^{37}$. В рамках Міжнародного плану імплементації (International Implementation Scheme (UNESCO, 2005a)) Десятиліття проводилося в два окремих етапи: перший етап (2005-2008 роки) був спрямований на визначення та просування Освіти для стійкого розвитку (ESD), виявлення учасників і розвиток партнерських стосунків. На другому етапі (2009-2014 рр.) акцент змістився на просування Освіти для стійкого розвитку (ESD) в контексті якісної освіти з акцентом на трьох ключових проблемах: зміни клімату, біорізноманіття та зменшення ризику катастроф (UNESCO, 2014a) ${ }^{38}$.

Боннська декларація (Bonn Declaration), прийнята в 2009 році на Всесвітній конференції ЮНЕСКО 3 освіти в інтересах стійкого розвитку (UNESCO World Conference on Education for Sustainable Development), що відбулася в Бонні (Німеччина), є поворотним моментом в поглядах і розумінні Освіти для стійкого розвитку (ESD) міністрами і забезпечує перехід до другого етапу. У Декларації наголошувалося на важливості інвестування в Освіту для стійкого розвитку (ESD) як на «засобі порятунку життя» для майбутнього, який дає людям можливість для здійснення змін (UNESCO, 2009: 1) ${ }^{39}$. Визнаючи, що «освіта є важливим чинником підвищення добробуту людей», Декларація рекомендує пропагувати Освіту для стійкого розвитку (ESD) як «інвестування в майбутнє», що безпосередньо пов'язано з двома процесами, які зв'язують освіту і стійкий розвиток ${ }^{40}$.

В ознаменування закінчення Десятиліття ООН у галузі Освіти для стійкого розвитку Всесвітня конференція по ОСР(ESD) в Айті-Нагоя в 2014 році підготувала Айті-Нагойську декларацію, в якій було вирішено переглянути цілі систем освіти з метою додати стійке майбутнє у якості спільної мети освіти. У АйтіНагойській декларації підкреслюється, що Освіта для стійкого розвитку (ESD) - це можливість і обов'язок, освіта, яка повинна привернути як розвинені країни, так і ті, що розвиваються до активізації зусиль для подолання бідності, скорочення нерівності, захисту навколишнього середовища та економічного зростання $з$ метою сприяння справедливій, більш стійкій економіці і суспільству, що приносить користь всім країнам» $(\text { UNESCO, 2014) })^{41}$.

Ці процеси ще раз підтвердили релевантність освіти для ключових питань стійкого розвитку, так само як і стійкого розвитку для освіти.

У якості продовження Десятиліття ООН по освіті для стійкого розвитку на Всесвітній конференції по ESD в Айті-Нагоя була прийнята Глобальна програма дій (Global Action Programme (GAP)) в освіті для стійкого розвитку (2015-2019 роки).

Як було підтверджено Генеральною конференцією ЮНЕСКО, Глобальна програма дій в ESD має cBоєї загальної метою «генерувати і розширювати дії на всіх рівнях і в галузях освіти і навчання для прискорення прогресу в напрямку стійкого розвитку» (UNESCO, 2014) ${ }^{42}$. Вона зводиться до двох завдань, перше з яких спрямоване на сектор освіти, покликаний «переорієнтувати освіту і навчання таким чином, щоб у кожного була можливість придбати знання, навички, цінності та підходи, які дають їм можливість робити внесок в стійкий розвиток». Друге завдання стосується всіх інших секторів, що мають відношення до стійкого розвитку, і вимагає від них «зміцнювати освіту і навчання у всіх порядках денних, програмах і заходах, що сприяють стійкому розвитку» (UNESCO, 2014). Ці два завдання засновані на двох процесах, розглянутих раніше, і, таким чином, є доказом того факту, що навчання такого шляху стійкого розвитку вимагає участі всіх верств суспільства, а не просто інтеграції в освіту питань, пов'язаних зі стійким розвитком.

${ }^{37}$ UNESCO (2005) United Nations Decade of Education for Sustainable Development (2005-2014): International Implementation Scheme. Paris, UNESCO. URL: https://unesdoc.unesco.org/ark:/48223/pf0000148654;

UNESCO (2014) Teaching and Learning: Achieving Quality for All. EFA Global Monitoring Report 2013-2014. Paris: UNESCO. URL: https://unesdoc.unesco.org/ark:/48223/pf0000225660

${ }^{38}$ UNESCO (2014) Global Citizenship Education: Preparing learners for the challenges of the 21stcentury. Paris: UNESCO. URL: http://www.eunec.eu/sites/www.eunec.eu/files/attachment/files/global citizenship education_report..pdf

${ }^{39}$ UNESCO (2009) Bonn Declaration. UNESCO World Conference on Education for Sustainable Development. Bonn: UNESCO, pp. 131. URL: https://unesdoc.unesco.org/ark:/48223/pf0000188799

${ }^{40}$ UNESCO (2009) Bonn Declaration. UNESCO World Conference on Education for Sustainable Development. Bonn: UNESCO, pp. 131. URL: https://unesdoc.unesco.org/ark:/48223/pf0000188799

${ }^{41}$ UNESCO (2014) Aichi-Nagoya Declaration on Education for Sustainable Development. Okayama, Japan: UNESCO. URL: https://sustainabledevelopment.un.org/content/documents/5859Aichi-Nagoya_Declaration_EN.pdf

${ }^{42}$ UNESCO (2014) UNESCO Roadmap for Implementing the Global Action Programme on Education for Sustainable Development. Paris: UNESCO. URL: https://unesdoc.unesco.org/ark:/48223/pf0000230514 
Однією з ключових особливостей майбутньої Глобальної програми дій в Освіті для стійкого розвитку (ESD) € концентрація зусиль на п'яти «пріоритетних напрямках»:

1. Розробка політики,

2. Перетворення середовища навчання і професійної підготовки,

3. Створення потенціалу викладачів та інструкторів,

4. Розширення прав і можливостей молоді та ії мобілізація,

5. Прискорення прийняття стійких рішень на місцевому рівні» (UNESCO, 2014: 15) 43.

${ }^{43}$ UNESCO (2014) Teaching and Learning: Achieving Quality for All. EFA Global Monitoring Report 2013-2014. Paris: UNESCO. URL: https://unesdoc.unesco.org/ark:/48223/pf0000225660 


\section{Взаємозв'язок між освітою і стійким розвитком}

Розвиток Освіти для стійкого розвитку відбувається у діалозі між освітою та стійким розвитком, тобто через інтеграцію освіти в стійкий розвиток та інтеграцію стійкого розвитку в освіту.

Як зазначалося вище, на протязі багатьох років для успішного досягнення цілей стійкого розвитку все більшого значення надається ролі освіти. Цей меседж зрозумілий; якщо люди в усьому світі не цінують і не застосовують принципи стійкого розвитку в своєму повсякденному виборі, ми ніколи не зможемо створити те майбутнє, яке хочемо. Спираючись на досягнення програми «Освіта для всіх» (Education for All), в останнє десятиліття ми твердо усвідомили виняткову важливість знань, навичок, цінностей і підходів, необхідних для вирішення ключових питань стійкої якості життя.

На сьогоднішній день Освіта для стійкого розвитку (ESD) просуває знання, навички, цінності та відносини, які дають учням можливість приймати усвідомлені рішення і проводити відповідальні заходи для забезпечення цілісності навколишнього середовища, економічної життєздатності і справедливого суспільства. В рамках Десятиліття ООН і Глобальної програми дій в інтересах Освіти для стійкого розвитку (Global Action Programme on ESD) були зроблені зусилля по включенню ESD в політику в галузі освіти, в навчальні програми та в підготовку вчителів. Необхідність продовжувати цей діалог між стійким розвитком і освітою актуальна як ніколи.

3 прийняттям 17 Цілей стійкого розвитку прихильними досягненню прогресу в галузі стійкого розвитку стали цілі континенти, регіони, країни, установи та окремі особи. Затребувана також осмислена, стратегічна і безперервна інтеграція або включення стійкого розвитку в освіту на всіх рівнях. Освіта в інтересах стійкого розвитку все частіше розуміється як наскрізний засіб для стійкого розвитку і всіх напрямків Цілей стійкого розвитку. Без сумніву, плідний діалог і співпраця між сектором освіти і секторами стійкого розвитку триватиме з ще більшим прискоренням. 


\section{Ключові компетентності в Освіті для стійкого розвитку}

Питання, як навчати для громадянства світу, якими мають бути компетентності в освіті для стійкого розвитку, досліджувалися такими авторами, як М. Рікманн (M. Rieckmann), A. Валс (A. Wals), Г. де Xaaн (G. de Haan), Дж. Годеманн (J.Godemann), Ф. Раух (F.Rauch), Р.Штайнер (R.Steiner), А. Вік (A.Wiek), Л. Візікомб (L. Withycombe), С. Редман (C.L. Redman) та ін. Особливої уваги заслуговує дослідження професора Університета Фехта Марка Рікманна «Навчання трансформації світу» (Rieckmann, 2018) ${ }^{44}$, в якому проаналізовано розвиток розуміння компетентностей в контексті нових реалій світу та в дискурсі Освіти для стійкого розвитку.

Освіта в інтересах стійкого розвитку (ESD) спрямована на розвиток компетентностей, які дозволяють людям рефлексувати над своїми власними діями, з урахуванням їх теперішніх та майбутніх соціальних, культурних, економічних і екологічних наслідків як з локальної, так і з глобальної точки зору. Вона вимагає, щоб люди діяли в складних ситуаціях стійким чином - вивчали нові ідеї та підходи і брали участь в суспільнополітичних процесах з метою поступового просування їх товариств до стійкого розвитку. Освіта (ESD), що розуміється таким чином, спрямована на те, щоб учні могли вживати відповідальні дії, що сприяють створенню стійких суспільств в сьогоденні і в майбутньому. Вона «розвиває навички, цінності та погляди, які дозволяють громадянам вести здорове і повноцінне життя, приймати обґрунтовані рішення і реагувати на місцеві та глобальні виклики» (UNESCO, 2016: IV) ${ }^{45}$.

Освіту для стійкого розвитку (ESD) слід розуміти як невід'ємну частину якісної освіти і навчання протягом усього життя. Всі навчальні заклади від дошкільної до вищої освіти, включаючи неформальну та інформальну освіту, повинні вважати своїм обов'язком займатися питаннями стійкого розвитку і сприяти розвитку ключових міждисциплінарних компетентностей, пов'язаних зі стійким розвитком. Розвиток цих компетентностей є важливим внеском в зусилля з досягнення Цілей стійкого розвитку (SDGs). Освіта для стійкого розвитку (ESD) дає людям не тільки знання для розуміння Цілей стійкого розвитку, але також і компетентності, що дозволяють їм брати участь у якості свідомих громадян в сприянні переходу до більш стійкого суспільства (UNESCO, 2017) $)^{46}$.

Освіта для стійкого розвитку (ESD) $€$ цілісною і трансформативною освітою, яка зачіпає зміст і результати навчання, педагогіку та навчальне середовище. На додаток до включення в навчальну програму і пріоритизації контенту зі зміни клімату, бідності та стійкого споживання, Освіта для стійкого розвитку (ESD) також створює інтерактивні, орієнтовані на учнів умови викладання і навчання. По суті, ця освіта вимагає переходу від викладання до навчання. Це набуває форми орієнтованої на дію трансформативної педагогіки, яка характеризується такими елементами, як самостійне навчання, участь і співробітництво, проблемне навчання, інтер- і трансдисциплінарність, а також зв'язок формального та інформального навчання. Такі педагогічні підходи необхідні для розвитку компетентностей, які є життєво важливими для сприяння стійкому розвитку.

Таким чином, виходячи з настанов ООН і ЮНЕСКО, Освіта для стійкого розвитку (ESD) нами розглядається як форма трансформативної і заснованої на компетентностях освіти. Компетентності, які має розвивати ця освіта, є орієнтованими на практичні дії і можуть бути сформовані на засадах трансформативної педагогіки.

${ }^{44}$ Rieckmann, M. (2018) Learning to transform the world: key competencies in Education for Sustainable Development. In: Leicht, A.; Heiss, J.; Byun, W. J. (eds) (2018) Issues and trends in Education for Sustainable Development, UNESCO Publishing. URL: https://unesdoc.unesco.org/ark:/48223/pf0000261445

${ }^{45}$ UNESCO (2016) Education 2030. Incheon Declaration and Framework for Action. Towards Inclusive and Equitable Quality Education and Lifelong Learning for All. Paris: UNESCO. URL: www.uis.unesco.org/Education/Documents/incheon-framework-for-action-en .pdf (accessed 17 May 2017).

${ }^{46}$ UNESCO (2017) Education for Sustainable Development Goals. Learning Objectives. Paris: UNESCO. URL: http://unesdoc.unesco.org/images/0024/002474/247444e.pdf (accessed 17 May 2017). 


\section{Освіта для стійкого розвитку (ESD) як трансформативна і заснована на компетентностях}

У всьому світі суспільство стикається з новими проблемами, пов'язаними з темпами технічного прогресу і глобалізації. До них відносяться зростаюча складність і невизначеність, зростаюча індивідуалізація і соціальна різноманітність, зростаюча економічна і культурна однаковість, деградація екосистемних послуг, від яких залежить суспільство, а також підвищена уразливість і схильність природним і технологічним небезпекам. Крім того, суспільство тепер має в своєму розпорядженні великий і безперервний потік інформації. Складність цих проблем - включаючи різноманітність залучених учасників, ситуацію і напрямки дій - не дозволяє використовувати лінійне моделювання процесів вирішення проблем, а замість цього вимагає нелінійного бачення ситуації та заснованих на ньому креативних і самоорганізованих дій.

Щоб зробити свій внесок у стійкий розвиток, люди мають навчитися, як розуміти складний світ, в якому вони живуть, і як впоратися з невизначеністю, ризиками, високою швидкістю соціальних змін глобального рівня, як віднаходити компроміси і рішення складних проблем на основі співпраці. Вони повинні бути здатними до співпраці, до того, щоб висловлюватися і діяти з метою досягнення позитивних змін на всіх рівнях життя (UNESCO, 2015a)" citizens») ${ }^{48}$ (Wals, 2015; Wals and Lenglet, 2016).

3 кінця 1990-х років дискурс щодо того, як навчати таких «громадян стійкості», змістився з орієнтації на сфокусований перелік обов'язкового освітнього контенту, на заснований на результатах компетентнісний підхід ${ }^{49}$ (Adomßent and Hoffmann, 2013; Wiek, Withycombe and Redman, 2011). До таких результатів належить надання людям можливості ефективно діяти і жити у все більш складному світі і робити свій внесок у перетворення його структур. Компетентнісний підхід заснований на визначенні того, які підходи найкраще працюють в реальному світі, а потім на визначенні того, як стимулювати необхідне навчання.

Як зазначалося вище, в контексті поточних глобальних проблем стверджувалося, що Освіта для стійкого розвитку (ESD) має дозволити людям замислитися про свої власні дії, беручи до уваги їх поточні і майбутні соціальні та екологічні наслідки - з глобальної точки зору. Тоді це дозволяє їм продуктивно брати участь у формуванні своїх дій більш стійким (тобто більш збалансованим, більш перспективно спрямованим) способом. Компетентнісний підхід може допомогти у цьому, щоб подолати розрив між знаннями і діями (див. Мал. 1).

У цьому контексті слід розглянути різницю між інструментальним, емансипаторським та компетентнісним підходами. Так, Bape (P. Vare) і Скотт (W. Scott,) розрізняють Освіту для стійкого розвитку 3 використанням інструментального підходу «ESD-1» і «ESD-2» з використанням емансипаторського підходу. Замість сприяння певній поведінці і способу мислення «ESD-1», що досягається на основі інструментального підходу, емансипаторський концепт Освіти для стійкого розвитку «ESD-2» фокусується, зокрема, на «створенні здатності критично мислити про те, що кажуть експерти (і не тільки вони), і перевіряти ідеї стійкого розвитку» і на «вивченні суперечностей, властивих стійкому життю» (Vare and Scott, 2007: 194) ${ }^{50}$. Ha цьому тлі Освіта для стійкого розвитку на засадах компетентнісного підходу (ії можна назвати «ESD-3») прагне розвивати здатності, що дозволяють людям брати участь у політичних процесах і, отже, просувати

\footnotetext{
${ }^{47}$ UNESCO (2015) Rethinking Education. Towards a Global Common Good? Paris: UNESCO. URL: http://unesdoc.unesco.org/images/0023/002325/232555e.pdf (accessed 17 May 2017).

${ }^{48}$ Wals, A.E.J. (2015) Beyond Unreasonable Doubt. Education and Learning for Socio-ecological Sustainability in the Anthropocene. Wageningen, Netherlands: Wageningen University. URL: https://arjenwals.files.wordpress.com/2016/02/8412100972 rvb inauguratiewals_oratieboekje_v02.pdf

(accessed 17 May 2017);

Wals, A.E.J. and Lenglet, F. (2016) Sustainability citizens: Collaborative and disruptive social learning. R. Horne, J. Fien, B. Beza and A. Nelson (eds), Sustainability Citizenship in Cities: Theory and Practice. London: Routledge. URL: https://www.routledge.com/SustainabilityCitizenship-in-Cities-Theory-and-practice/Horne-Fien-Beza-Nelson/p/book/9781138933637

${ }^{49}$ Adomßent, M. and Hoffmann, T. (2013) The Concept of Competencies in the Context of Education for Sustainable Development (ESD). URL: http://esdexpert.net/assets/130314-Concept-Paper-ESD-Competencies.pdf

(accessed 17 May 2017);

Wiek, A., Withycombe, L. and Redman, C.L. (2011) Key competencies in sustainability: a reference framework for academic program development. Sustainability Science, 6(2), 203-218. URL: https://link.springer.com/article/10.1007/s11625-011-0132-6

${ }^{50}$ Vare, P. and Scott, W. (2007) Learning for a change: exploring the relationship between education and sustainable development. Journal of Education for Sustainable Development, 1(2): 191-198. URL: https://www.researchgate.net/publication/258157776 Learning for a Change
} 
своє суспільство до стійкого розвитку (Rieckmann, 2012; Wiek, Withycombe and Redman, 2011) ${ }^{51}$. Підхід до Освіти для стійкого розвитку з точки зору компетентності (або «ESD-3») дозволяє досліджувати ключові області, необхідні для успіху в галузі стійкого розвитку.

Відповідно, в Глобальній програмі дій (GAP) про Освіту для стійкого розвитку (ESD) говориться:

ESD дозволяє кожній людині здобувати знання, навички, цінності та погляди, які дають їм можливість робити свій внесок у стійкий розвиток, приймати обґрунтовані рішення і вживати відповідальні дії для забезпечення збереження навколишнього середовища, економічної життєздатності і справедливого суспільства для нинішнього і майбутніх поколінь. Освіта для стійкого розвитку (ESD) розвиває такі навички, як критичне мислення, розуміння складних систем, прогнозування сценаріїв майбутнього і прийняття рішень на основі участі та співпраці (UNESCO, 2014: 33) ${ }^{52}$.

Емансипаторський підхід в Освіті для стійкого розвитку (ESD) спрямований на виявлення ключових компетентностей, необхідних для того, щоб учні стали «громадянами стійкості». Відповідно, в Глобальній програмі дій (GAP) підкреслюються результати навчання, які стимулюють навчання і сприяють розвитку основних компетентностей, таких як «критичне і системне мислення, спільне прийняття рішень і прийняття відповідальності за нинішнє і майбутні покоління» (UNESCO, 2014b: 12) ${ }^{53}$.

Все більше дослідників вивчають взаємопов'язані аспекти Освіти для стійкого розвитку (ESD) i пов'язані з ними компетентності (de Haan, 2010; Glasser and Hirsh, 2016; Rieckmann, 2012; Wiek, Withycombe and Redman, 2011; Wiek et al., 2016) ${ }^{54}$. Серед них вони виокремлюють ключові компетентності, необхідні для того, щоб люди могли змінити свій спосіб мислення і життя і зробити свій внесок у перетворення суспільства в напрямку стійкості.

\footnotetext{
${ }^{51}$ Rieckmann, M. (2012) Future-oriented higher education: which key competencies should be fostered through university teaching and learning? Futures, 44(2): 127-135. URL: https://www.researchgate.net/publication/232364850 Futureoriented_higher_education_Which_key_competencies_should_be_fostered_through_university_teaching_and_learning; Wiek, A., Withycombe, L. and Redman, C.L. (2011) Key competencies in sustainability: a reference framework for academic program development. Sustainability Science, 6(2), 203-218. URL: https://link.springer.com/article/10.1007/s11625-011-0132-6

52 UNESCO (2014) UNESCO Roadmap for Implementing the Global Action Programme on Education for Sustainable Development. Paris: UNESCO. URL: http://unesdoc.unesco.org/images/0023/002305/230514e.pdf

(accessed 17 May 2017).

53 UNESCO (2014) UNESCO Roadmap for Implementing the Global Action Programme on Education for Sustainable Development. Paris: UNESCO. URL: http://unesdoc.unesco.org/images/0023/002305/230514e.pdf

54 de Haan, G. (2010) The development of ESD-related competencies in supportive institutional frameworks. International Review of Education, 56(2): 315-328. URL: https://www.researchgate.net/publication/225773272_The_development_of_ESDrelated competencies in supportive institutional frameworks;

Glasser, H. and Hirsh, J. (2016) Toward the development of robust learning for sustainability core competencies. Sustainability: The Journal of Record, 9(3): 121-134. URL: https://wmich.edu/sites/default/files/attachments/u159/2016/2016\%20Core\%20Competencies.pdf; Rieckmann, M. (2012) Future-oriented higher education: which key competencies should be fostered through university teaching and learning? Futures, 44(2): 127-135. URL: https://www.researchgate.net/publication/232364850 Futureoriented_higher_education_Which_key_competencies_should_be_fostered_through_university_teaching_and_learning;

Rieckmann, M. (2018) Learning to transform the world: key competencies in Education for Sustainable Development. In: Leicht, A.; Heiss, J.; Byun, W. J. (eds) (2018) Issues and trends in Education for Sustainable Development, UNESCO Publishing. URL: https://unesdoc.unesco.org/ark:/48223/pf0000261445;

Wiek, A., Withycombe, L. and Redman, C.L. (2011) Key competencies in sustainability: a reference framework for academic program development. Sustainability Science, 6(2), 203-218. URL: https://link.springer.com/article/10.1007/s11625-011-0132-6;

Wiek, A., Bernstein, M.J., Foley, R.W., Cohen, M., Forrest, N., Kuzdas, C., Kay, B. and Withycombe Keeler, L. (2016) Operationalising competencies in higher education for sustainable development. In: M. Barth, G. Michelsen, I. Thomas and M. Rieckmann (eds), Routledge Handbook of Higher Education for Sustainable Development. London: Routledge, 241-260. URL: https://www.academia.edu/627055/Key competencies in sustainability a reference framework for academic program development
} 


\section{Ключові компетентності для стійкого розвитку}

Проект OECD «Визначення та селекція компетентностей» (DeSeCo) класифікує ключові компетентності за трьома категоріями: інтерактивне використання інструментів (здатність інтерактивно використовувати мову, символи та тексти, здатність інтерактивно використовувати знання та інформацію і вміння використовувати технології в інтерактивному режимі) ; взаємодія в гетерогенних групах (здатність добре ставитися до інших, здатність співпрацювати і здатність справлятися з конфліктами і вирішувати ї); діяти автономно (здатність діяти в рамках загальної картини; здатність складати і здійснювати життєві плани і особисті проекти; а також здатність захищати і відстоювати права, інтереси, обмеження і потреби) (Rychen, $2003)^{55}$.

Ця система компетентностей складається з наступних ключових компетентностей для формування або трансформування майбутнього:

- збирати знання в дусі відкритості до світу, інтегрувати їх у відповідності з іншими імперативами думати і діяти на перспективу;

- здобувати знання і діяти на міждисциплінарній основі;

- мати справу з неповною і надзвичайно складною інформацією;

- співпрацювати в процесах прийняття рішень;

- індивідуально справлятися з дилемами прийняття рішень;

- брати участь у колективних процесах прийняття рішень;

- мотивувати себе та інших, щоб стати активними;

- рефлексувати над своїми принципами і засадами інших людей;

- звертатися до ідеї справедливості при прийнятті рішень і плануванні дій;

- планувати і діяти автономно;

- проявляти співчуття і солідарність зі знедоленими (de Haan, 2010) ${ }^{56}$.

B рамках дослідження Delphi експертами в області Освіти для стійкого розвитку (ESD) з Чилі, Еквадору, Німеччини, Мексики і Великої Британії був складений наступний перелік ключових компетентностей, який наводить М. Рікманн:

- системне мислення і вміння справлятися зі складністю,

- прогностичне мислення,

- критичне мислення,

- вміння діяти справедливо і екологічно,

- співпраця в (гетерогенних) групах,

- участь в обговоренні та діяльності,

- емпатія і здатність до зміни перспективи,

- здатність до інтердисциплінарної роботи,

- комунікація та використання засобів масової інформації,

- планування і реалізація інноваційних проектів,

- вміння оцінювати,

- толерантність до невизначеності і фрустрації (компетентність щодо толерантності до

невизначеності і фрустрації відноситься до рішення конфліктів, конкуруючих цілей і інтересів, протиріч і невдач) (Rieckmann, 2012) ${ }^{57}$.

${ }^{55}$ Rychen, D.S. (2003) Key competencies: meeting important challenges in life. In: D.S. Rychen and L.H. Salganik (eds), Key Competencies for a Successful Life and Well-functioning Society. Cambridge, MA: Hogrefe and Huber, 63-107.

URL: https://pubengine2.s3.eu-central-1.amazonaws.com/preview/99.110005/9781616762728 preview.pdf

${ }^{56}$ De Haan, G. (2010) The development of ESD-related competencies in supportive institutional frameworks. International Review of Education, 56(2): 315-328. URL: https://www.researchgate.net/publication/225773272_The development_of_ESDrelated competencies in supportive institutional frameworks

${ }^{57}$ Rieckmann, M. (2012) Future-oriented higher education: which key competencies should be fostered through university teaching and learning? Futures, 44(2): 127-135. URL: https://www.researchgate.net/publication/232364850 Futureoriented higher education Which key competencies should be fostered through university teaching and learning 
A. Валс (Wals, 2015) ${ }^{58}$ розрізняє наступні засновані на компетентностях аспекти стійкості:

- динаміка і зміст стійкості,

- критичний аспект стійкості,

- аспект стійкості, що стосується змін та інновацій,

- а також екзистенційний і нормативний аспекти стійкості.

A. Вік і його співавтори (Wiek et al., 2016) ${ }^{59}$ оновили свій перелік, який раніше включав в себе п'ять ключових компетентностей, додавши в 2016 році шосту (компетентність в області вирішення проблем):

- компетентність системного мислення,

- прогностична компетентність,

- нормативна компетентність,

- стратегічна компетентність,

- міжособистісна компетентність

- загальна компетентність в області вирішення проблем.

Їх робота зіграла важливу роль у зближенні багатьох з цих концепцій та переліків, а також у наданні структури для полегшення дискусії про компетентності, що вважаються критично важливими для стійкості (Wiek, Withycombe and Redman, 2011) ${ }^{60}$.

Глассер і Хірш (Glasser and Hirsh, 2016) ${ }^{61}$ визначили п'ять додаткових ключових компетентностей стійкості:

- зв'язок з життям,

- знання про стан планети,

- мудре прийняття рішень,

- моделювання стійкої поведінки,

- моделювання трансформативних соціальних змін.

Хоча ці переліки демонструють певні відмінності, в ряді випадків вони також збігаються щодо визначення ключових компетентностей в області стійкості. Узагальнюючи, можна зробити висновок, що у міжнародному дискурсі Освіти для стійкого розвитку (ESD), існує загальна згода щодо особливого значення для мислення і дій в інтересах стійкого розвитку наступних ключових компетентностей в області стійкості:

Компетентність в області системного мислення:

- здатність розпізнавати і розуміти відносини,

- аналізувати складні системи,

- розуміти те, як системи вбудовані в різні області і в різних масштабах,

- справлятися з невизначеністю;

Прогностична компетентність:

- здатність розуміти і оцінювати кілька варіантів майбутнього - можливого, ймовірного і бажаного і створювати своє бачення майбутнього,

- застосовувати принцип обережності, оцінювати наслідки дій і справлятися з ризиками і змінами;

${ }^{58}$ Wals, A.E.J. (2015) Beyond Unreasonable Doubt. Education and Learning for Socio-ecological Sustainability in the Anthropocene. Wageningen, Netherlands: Wageningen University. URL: https://arjenwals.files.wordpress.com/2016/02/8412100972_rvb inauguratiewals oratieboekje v02.pdf

(accessed 17 May 2017).

${ }^{59}$ Wiek, A., Bernstein, M.J., Foley, R.W., Cohen, M., Forrest, N., Kuzdas, C., Kay, B. and Withycombe Keeler, L. (2016) Operationalising competencies in higher education for sustainable development. In: M. Barth, G. Michelsen, I. Thomas and M. Rieckmann (eds), Routledge Handbook of Higher Education for Sustainable Development. London: Routledge, 241-260. URL: https://www.academia.edu/627055/Key competencies in sustainability a reference framework for academic program development

${ }^{60}$ Wiek, A., Withycombe, L. and Redman, C.L. (2011) Key competencies in sustainability: a reference framework for academic program development. Sustainability Science, 6(2), 203-218. URL: https://link.springer.com/article/10.1007/s11625-011-0132-6

${ }^{61}$ Glasser, H. and Hirsh, J. (2016) Toward the development of robust learning for sustainability core competencies. Sustainability: The Journal of Record, 9(3): 121-134. URL: https://wmich.edu/sites/default/files/attachments/u159/2016/2016\%20Core\%20Competencies.pdf 
Нормативна компетентність:

- здатність розуміти і рефлексувати над нормами і цінностями, що лежать в основі власних дій та дій інших,

- обговорювати цінності, принципи, цілі та завдання в області стійкості в контексті конфлікту інтересів і взаємних поступок, невизначеності знань і протиріч, компромісів;

Стратегічна компетентність:

- здатність колективно розробляти і реалізовувати інноваційні дії, що сприяють стійкості на місцевому рівні і за його межами;

Компетентність в області співпраці:

- здатність вчитися у інших;

- розуміти і поважати потреби, перспективи і дії інших (емпатія);

- розуміти і бути чуйним до інших (емпатичне лідерство),

- вміння вирішувати конфлікти в групі;

- сприяти спільній і активній участі у вирішенні проблем;

Компетентність в області критичного мислення:

- здатність ставити під сумнів норми, практики і думки;

- рефлексувати над своїми власними цінностями, розуміннями і діями;

- вміння зайняти позицію в дискурсі про стійкість;

Компетентність в області самосприйняття:

- здатність рефлексувати над своєю роллю в місцевому співтоваристві і (глобальному) суспільстві,

- постійно оцінювати і додатково мотивувати свої дії і справлятися зі своїми почуттями і бажаннями;

Загальна компетентність в області вирішення проблем:

- загальна здатність застосовувати різні способи вирішення проблем до складних проблем стійкості і виробляти життєздатні, всеосяжні і справедливі рішення, які сприятимуть стійкому розвитку - здатність до інтеграції вищезазначених компетентностей.

У цьому переліку виділені компетентності, які особливо важливі для стійкості і які не були в центрі уваги формальної освіти. Хоча кожна компетентність має свої власні якості та області релевантності, вони $\epsilon$ взаємозалежними. Ось чому загальна (інтегративна) компетентність в області вирішення проблем має особливе значення. Вирішальне значення для стійкого розвитку мають базові компетентності, такі як навички спілкування. Крім того, ключові компетентності у сфері стійкого розвитку необхідно розвивати у поєднанні 3 базовими компетентностями (Wiek, Withycombe and Redman, 2011) 62. $^{62}$

Однак, хоча компетентності описують здатність або схильність діяти для вирішення складних завдань, це не обов'язково визначає, що людина буде діяти певним чином в конкретній ситуації. Отже, щоб перетворити здатності в реальні стійкі дії, людям потрібні відповідні цінності і мотивуючі фактори.

Крім того, показники стійкості пов'язані з оточенням людини, розуміються як можливості для діяльності, які знаходяться поза їі контролем. 3 цієї точки зору, можливостями $є$ екологічні та контекстуальні механізми, які дозволяють діяти. Іншими словами, вони представляють собою умови, які забезпечують необхідну підтримку і можливості для дій, орієнтованих на дії на основі стійкості. Спираючись на підхід на основі можливостей, Nussbaum (2000) ${ }^{63}$ підкреслює виняткову важливість інститутів управління в забезпеченні таких структур можливостей, які дають людям можливість діяти.

Відповідно до цього підходу ефективність стійкості залежить від взаємодії знань і навичок, цінностей і мотиваційних чинників, а також від можливостей. Взаємозв'язок цих аспектів впливає на особисту поведінку (мал. 1).

\footnotetext{
${ }^{62}$ Wiek, A., Withycombe, L. and Redman, C.L. (2011) Key competencies in sustainability: a reference framework for academic program development. Sustainability Science, 6(2), 203-218. URL: https://link.springer.com/article/10.1007/s11625-011-0132-6

${ }^{63}$ Nussbaum, M.C. (2010) Creating Capabilities: The Human Development Approach. Cambridge: Belknap Press of Harvard University Press. URL: https://www.hup.harvard.edu/catalog.php?isbn=9780674072350\&content=reviews
} 


\section{Iнтеграція ESD у практику освіти і педагогіку}

\section{Загальноінституціональний, або комплексний підхід}

Освіта для стійкого розвитку (ESD) - це не просто питання викладання стійкого розвитку і додавання нового контенту в курси і тренінги. Заклади вищої освіти (коледжі, інститути, університети), наприклад, мають розглядатися як місця практичного навчання стійкому розвитку і тому повинні орієнтувати всі свої процеси на принципи стійкості. Щоб Освіта для стійкого розвитку (ESD) була більш ефективною, має бути трансформовано навчальний заклад в цілому. Такий холістичний, комплексний, тобто загальноінституціональний підхід спрямований на забезпечення стійкості у всіх аспектах навчального закладу. Комплексність потребує переосмислення навчальної програми, функцій забезпечення життєдіяльності закладу, тобто тих, хто навчає, і тих, хто навчається (кампусу), організаційної культури, участі студентів, лідерства та управління, відносин між людьми і досліджень (UNESCO, 2014а). Таким чином, рольовою моделлю для студентів $€$ сам навчальний заклад. Стійке середовище навчання (наприклад, екошколи або зелені кампуси як приклади з інших країн), дозволяє викладачам і учням інтегрувати принципи стійкості у свою повсякденну практику і сприяти нарощуванню потенціалу і розвитку компетентностей та оцінювати освіту з різних сторін.

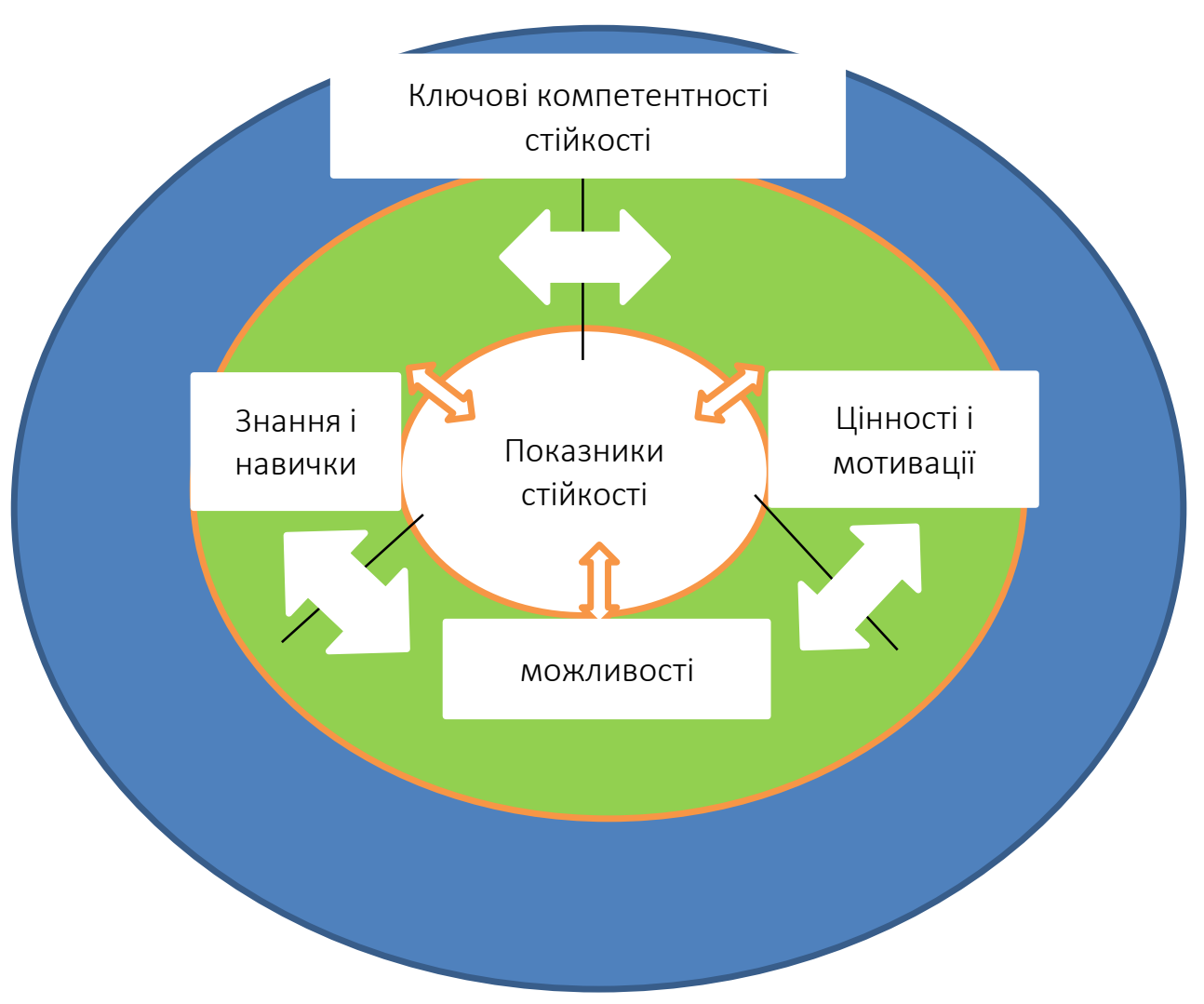

Мал. 1: Ключові компетентності стійкого розвитку суспільства (Джерело: Rieckmann, 2018) 


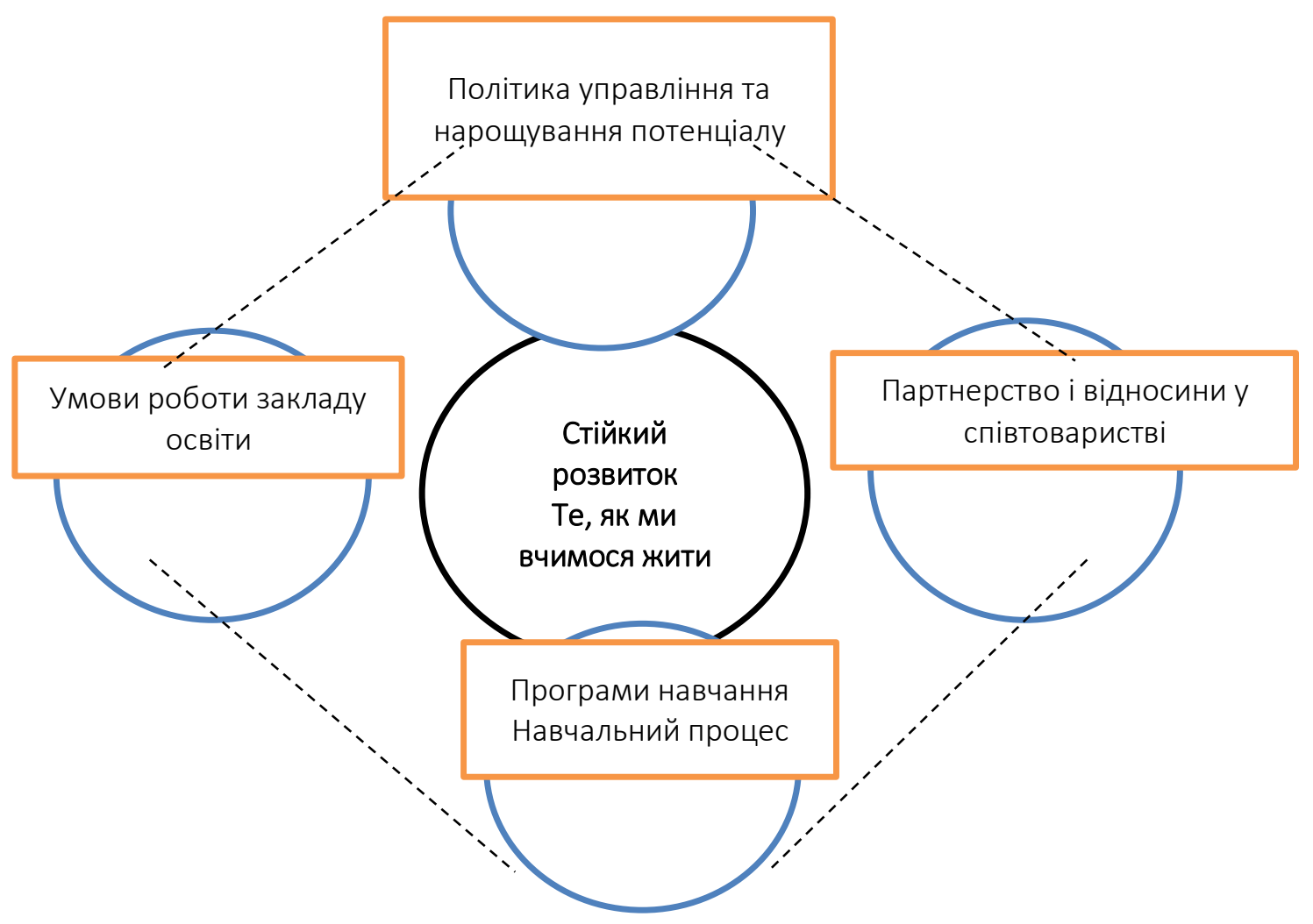

Мал. 2: Загальноінституиіональний підхід (Джерело: UNESCO, 2014a: 89).

3 огляду на важливість трансформування всього навчального закладу, пріоритетний напрямок Глобальної програми дій 2 ( «Трансформування середовища навчання і тренінгу: інтеграція принципів стійкості в середовище освіти і тренінгу») закликає до «просування загальноінституціональних підходів до Освіти для стійкого розвитку (ESD) в школах і всіх інших навчальних закладах» (UNESCO 2014: 18) ${ }^{64}$. Таким чином, слід заохочувати загальноінституціональні підходи на всіх рівнях і в будь-яких умовах. Відповідно, всім навчальним закладам, а також організаціям державного та приватного секторів рекомендується впроваджувати плани або стратегії стійкого розвитку. ЮНЕСКО рекомендує розширити наявний досвід застосування загальноінституціональних підходів у сфері вищої освіти і поширити його на інші рівні і типи освіти, такі як дошкільна освіта, середня освіта, технічна та професійна освіта і навчання, а також неформальна освіта для молоді та дорослих.

\section{Ключові елементи загальноінституціональних підходів (UNESCO, 2014)}

1. Загальноінституціональний процес має бути організований таким чином, щоб всі зацікавлені сторони - керівництво, викладачі, учні, адміністрація - могли спільно розробити бачення і план по впровадженню Освіти для стійкого розвитку (ESD) у всьому навчальному закладі.

2. Технічна і, де це можливо і доцільно, фінансова підтримка має надаватися установі для підтримки їі переорієнтації. Вона може включати в себе надання релевантних прикладів передового досвіду, тренінг для керівників та адміністрації, розробку посібників, а також відповідні дослідження.

3. Існуючі релевантні міжвідомчі мережі мають бути мобілізовані і розширені для сприяння взаємній підтримці, такій як взаємне навчання на основі загальноінституціонального підходу.

${ }^{64}$ UNESCO (2014) UNESCO Roadmap for Implementing the Global Action Programme on Education for Sustainable Development. Paris: UNESCO. URL: http://unesdoc.unesco.org/images/0023/002305/230514e.pdf

(accessed 17 May 2017). 
Хоча всі елементи загальноінституціонального підходу $є$ важливими, в основі забезпечення Освіти для стійкого розвитку (ESD) мають бути інтерактивні інтегративні і критичні форми навчання, що робить цей підхід, орієнтованим на дію і трансформативну педагогіку.

\section{Ключові педагогічні підходи в ESD}

Освіта для стійкого розвитку (ESD) - це розвиток компетентностей в області стійкості і, таким чином, розширення можливостей і мотивації учнів стати активними і критичними «громадянами стійкості», здатними забезпечити стійкість, здатними брати участь у формуванні стійкого майбутнього. Педагогічні підходи, необхідні для досягнення цієї мети, мають бути орієнтовані на учнів, орієнтовані на дії та трансформативність.

\section{1. Підхід, орієнтований на учня}

Педагогіка, орієнтована на учня, розглядає його як автономного суб'єкта навчання і робить акцент на активний розвиток знань, а не просто на передачу або пасивні методи навчання. Відправним пунктом для стимулювання навчального процесу, в якому учні створюють свою власну базу знань, $€$ їх попередні знання, а також їх досвід, набутий у соціальному контексті. Підхід, орієнтований на учня, вимагає від учнів рефлексії щодо власних знань і навчального процесу для того, щоб керувати і контролювати їх. Викладачі повинні стимулювати і підтримувати таку рефлексію. Підхід, орієнтований на учня, змінює роль викладача як експерта і передавача знань на роль посередника (фасилітатора) навчального процесу (Barth, 2015) ${ }^{65}$.

\section{2. Навчання, орієнтоване на дію}

У навчальному процесі, орієнтованому на дію, учні беруть участь у діяльності та розмірковують над своїм досвідом з точки зору свідомого освітнього процесу та особистого розвитку. Такий досвід може бути набутий у процесі участі у проекті (підвищення кваліфікації), стажування, участі у семінарі у якості фасилітатора, проведення кампанії і т.п. Навчання на основі дії пов'язано з теорією циклу навчання Кольба (Kolb, 1984) ${ }^{66}$ на основі досвіду, який складається з наступних етапів:

1. Придбання конкретного досвіду,

2. Спостереження і рефлексія,

3. Формування абстрактних концептів для узагальнення,

4. Застосування їх до нових ситуацій.

Навчання, орієнтоване на дію, сприяє набуттю знань, розвитку компетентності та з'ясуванню цінностей, пов'язуючи абстрактні концепти з особистим досвідом і життям учня. Роль викладача полягає у створенні середовища навчання, яке спонукає учнів переживати і рефлексувати над процесами мислення.

\section{3. Трансформативне навчання}

Трансформативне навчання найкраще можна визначити за його цілями і принципами, а не за конкретними стратегіями викладання або навчання. Воно спрямоване на розвиток здатності учнів оскаржити і змінити те, як вони бачать світ і думають про нього, для того, щоб поглибити його розуміння ${ }^{67}$.

Викладач $€$ фасилітатором, який розвиває здатність учнів змінювати свій світогляд. Пов'язаний з ним концепт трансгресивного навчання ${ }^{68}$ робить ще один крок вперед: він підкреслює, що навчання в Освіті для стійкого розвитку має долати статус-кво і готувати учня для мислення, що долає парадигмальні i дисциплінарні та інші кордони , і співучасті у створенні нового синтетичного знання.

Для створення різноманітних умов навчання, що сприяють перетинанню кордонів, і створення цілісної, всеохоплюючої картини Цілей стійкого розвитку, освітні заклади та викладачі мають зміцнювати партнерство на місцевому, національному та міжнародному рівні. Важливо визнати, що адекватні реакції на проблеми стійкості не можна обмежувати окремими поглядами, дисциплінами або способами пізнання. Партнерство, в яке залучений ряд таких соціальних акторів як бізнес, недержавні організації, державні

${ }^{65}$ Barth, M. (2015)Implementing sustainability in higher education: learning in an age of transformation. London, Routledge.

${ }^{66}$ Kolb, D. A. (1984) Experiential Learning: Experience as the Source of Learning and Development. Englewood Cliffs, N.J., Prentice-

Hall

${ }^{67}$ Slavich, G. M. and Zimbardo, P. G. 2012. Transformational Teaching: Theoretical Underpinnings. Basic Principles, and Core Methods. Educational Psychology Review, Vol. 24, No. 4, 569-608;

Mezirow, J. 2000. Learning as transformation: critical perspectives on a theory in progress. San Francisco, Jossey-Bass.

${ }^{68}$ Lotz-Sisitka, H., Wals, A.E., Kronlid, D. and McGarry, D. (2015) Transformative, transgressive social learning: rethinking higher education pedagogy in times of systemic global dysfunction. Current Opinion in Environmental Sustainability, 16: 73-80. URL:

http://www.openensemble.se/wp-content/uploads/2018/08/lotzwalskronlidmcgarytransgressivesociallearning.pdf 
інститути, люди, які приймають політичні рішення або окремі індивіди, створює нові можливості для навчання і стає джерелом креативності та інновацій.

У діалозі або у проекті, який передбачає співпрацю з партнером на практиці, студенти можуть дізнатися про проблеми реального світу і отримати вигоду з досвіду і експертних знань партнерів. Одночасно партнери також можуть розширити свої можливості, а їх здатність бути важливим агентом змін може зрости. Партнерство між учнями всього світу сприяє обміну різними поглядами і знань стосовно одного і того ж. Наприклад, віртуальні курси можуть створити середовище для глобального діалогу і сприяння взаємній повазі і взаєморозумінню.

Підсумовуючи виклад цього фрагменту методичних рекомендацій, слід зауважити, що Освіта для стійкого розвитку може сприяти досягненню Цілей стійкого розвитку, по-перше, розвиваючи міждисциплінарні компетентності стійкості, які необхідні для вирішення багатьох різних проблем стійкості і для забезпечення зв'язку один з одним різних Цілей. По-друге, Освіта для стійкого розвитку може надати конкретні когнітивні, соціо-емоційні та поведінкові результати навчання, які дозволяють їм вирішувати конкретні проблеми кожної Цілі стійкого розвитку.

Для того, щоб необхідна критична кількість людей у світі стали діяти відповідно до Цілей стійкого розвитку, всі освітні заклади мають взяти на себе відповідальність за те, щоб активно займатися проблемами стійкого розвитку, сприяти розвитку компетентностей стійкості і домагатися конкретних результатів навчання, пов'язаних з Цілями стійкого розвитку. Тому життєво важливо не тільки включити в освітні програми контент, пов'язаний з Цілями стійкого розвитку, але також використовувати в навчальному процесі трансформативну педагогіку, орієнтовану на дію.

Управлінці у сфері освіти, люди, які приймають політичні рішення, викладачі, розробники освітніх програм та інші, пов'язані з освітою люди, мають переосмислити освіту в інтересах сприяння досягненню Цілей стійкого розвитку в термін від теперішнього часу до 2030 року. Освіта має бути зорієнтованою на компетентності стійкості і конкретні когнітивні, соціо-емоційні і поведінкові результати навчання, які $€$ релевантними цим цілям. 


\section{Ключові методи в Освіті для стійкого розвитку}

У той час як такі педагогічні підходи описують загальний характер або керівні принципи для розробки процесів навчання в ESD, для полегшення процесу навчання необхідні конкретні методи, які відповідають цим принципами. ESD надає перевагу методам, які сприяють формуванню компетентностей стійкості за допомогою активного навчання. Деякі методи можуть бути особливо рекомендовані в Освіті для стійкого розвитку (ESD), а саме:

- Спільні проекти в реальному світі, такі як проекти навчання на практиці і кампанії з різних тем стійкого розвитку;

- Вправи для формування бачення, такі як семінари про майбутнє, аналіз сценаріїв, обговорення утопічних / антиутопічних історій, науково-фантастичні роздуми, а також перспективний і ретроспективний аналіз;

- Аналіз складних систем, включаючи дослідницькі проекти на рівні спільноти, тематичні дослідження, аналіз зацікавлених сторін, аналіз акторів, моделювання і системні ігри;

- Критичне і рефлексивне мислення, в тому числі за допомогою дискусій у формі фіш-боул (fish-bowl discussions) і рефлексивних журналів.

Такі активні методи викладання та навчання дозволяють учням брати участь у діях, які сприяють стійкому розвитку. При виборі методів викладання і навчання необхідно виходити із конкретних умов. Ці методи повинні відповідати потребам групи учнів (наприклад, віку, попереднім знанням, інтересам і здібностям), контексту, в якому відбувається навчання (наприклад, місцю в навчальній програмі, педагогічному клімату і культурним традиціям) , а також наявним ресурсам і доступній підтримці (наприклад, компетентності вчителів, навчальним матеріалам, технологіям і коштам).

Щоб створити різноманітні і транскордонні (cross-boundary) умови навчання і скласти цілісну, всеосяжну картину глобальних проблем стійкості (включаючи Цілі Стійкого Розвитку), навчальні заклади та викладачі мають розвивати партнерські відносини на місцевому, національному та міжнародному рівнях. Визнаючи, що адекватні відповіді на виклики стійкості не можуть бути обмежені окремими точками зору, дисциплінами або методами пізнання, важливо розуміти, що навчання в рамках партнерства (за участю ряду громадських суб'єктів, таких як підприємства, неурядові організації, державні установи та особи, що формують політику, стає джерелом творчості та інновацій. Такі діалоги або проекти дозволяють студентам вчитися на реальних проблемах, а також на експертних знаннях і досвіді партнерів. У той же час вони можүть допомогти партнерам і збільшувати їх потенціал у якості найважливіших агентів змін. Крім того, партнерські відносини між учнями з усього світу сприяють обміну різними точками зору і знаннями з аналогічних тем. Наприклад, віртуальні курси можуть забезпечити створення середовища для початку глобальних діалогів і сприяти взаємній повазі і розумінню.

Орієнтована на дії трансформативна педагогіка також сприяє досягненню цілей Пріоритетного напрямку дій 4 Глобальної Програми Дій («Розширення прав і можливостей та мобілізація молоді»), який вимагає «більш якісних можливостей електронного навчання молоді; участі та сприяння молоді в пропаганді ESD, розробці та реалізації політики на місцевому, національному та міжнародному рівнях; і більшої активності молоді щодо ESD» (UNESCO, 2014: 23) ${ }^{69}$.

69 UNESCO (2014) UNESCO Roadmap for Implementing the Global Action Programme on Education for Sustainable Development. Paris: UNESCO. URL: http://unesdoc.unesco.org/images/0023/002305/230514e.pdf

(accessed 17 May 2017). 


\section{Оцінювання результатів навчання в Освіті для стійкого розвитку (ESD)}

Оцінка як результатів ESD, так і зусиль, спрямованих на переорієнтацію систем освіти, є складним завданням ${ }^{70}$. На сьогоднішній день мало що відомо про якість програм по ESD, ступінь їх реалізації та їх ефективності в досягненні бажаних змін в показниках навчання (знаннях, компетентностях, поглядах, цінностях і поведінці). Програми та ініціативи в Освіті для стійкого розвитку мають оцінюватися на декількох рівнях, зокрема:

- на рівні широкомасштабної оцінки результатів навчання,

- оцінки результатів навчання на індивідуальному рівні,

- на рівні загальнонаціональної оцінки, яка більш відповідає національним пріоритетам у галузі

освіти,

- на рівні контекстуалізованої шкільної та інституційної оцінки для покращення імплементації та надання ESD розвитку практики формативного оцінювання, що дозволяє педагогам оцінювати конкретні педагогічні практики в класах,

- на рівні особистої самооцінки індивідуального прогресу.

\section{Приклади очінок, які включають в себе елементи $E S D^{71}$}

Сьогодні міжнародні оцінки показників навчання вже починають включати в себе аспекти Освіти для стійкого розвитку. Оцінка PISA (Міжнародна програма з оцінки освітніх досягнень учнів (Programme for International Student Assessment, PISA) 2006 була присвячена природничій грамотності і, серед іншого, зібрала інформацію про включення у шкільну програму тематики науки про навколишнє середовище (OECD, $2009)^{72}$. Було виявлено, що 98 відсотків учнів в країнах OECD відвідують школи, в яких викладаються екологічні теми (наприклад, забруднення навколишнього середовища, деградація навколишнього середовища, взаємовідносини між організмами, біорізноманіття та збереження природних ресурсів). Хоча навчальні програми за темами природничих наук можуть відрізнятися в різних системах, більшість учнів молодших класів середніх шкіл в країнах ОЕCD стикалися з низкою ключових екологічних тем і повинні були опанувати ними. Серед учнів в країнах, що не входять в OECD, можливості дізнатися про навколишнє середовище значно різняться.

\section{Оцінка вибору і дій, пов'язаних зі стійкістю}

Ще складніше визначити, чи приводять знання і показники навчання до вибору рішень і дій, пов'язаних зі стійкістю. У цій області $є$ кілька багатообіцяючих ініціатив: наприклад, Міжнародне дослідження цивільних прав та громадянства (ICCS) в тридцяти восьми країнах, проведене в 2008 і 2009 роках, профінансоване Міжнародною асоціацією з оцінки досягнень у галузі освіти, виявило позитивну кореляцію між освітою в області громадянства та участю учнів в активній громадській діяльності (Schulz et al., 2010) ${ }^{73}$.

У 2013 році Рада голів PISA (Programme for International Student Assessment, OECD) прийняла рішення провести оцінку «глобальної компетентності» в рамках оцінки PISA 2018 року. Глобальна компетентність визначається OECD як здатність критично і з різних точок зору аналізувати глобальні та міжкультурні проблеми, щоб розуміти, як відмінності впливають на сприйняття, судження та уявлення про себе та інших, і

${ }^{70}$ UNESCO (2014) Shaping the Future We Want. UN Decade of Education for Sustainable Development (2005-2014). Final Report. Paris: UNESCO. URL: http://unesdoc.unesco.org/images/0023/002301/230171e.pdf

(accessed 17 May 2017).

${ }^{71}$ UNESCO (2014) Shaping the Future We Want. UN Decade of Education for Sustainable Development (2005-2014). Final Report. Paris: UNESCO, 98. URL: http://unesdoc.unesco.org/images/0023/002301/230171e.pdf

(accessed 17 May 2017).

${ }^{72}$ OECD (2009) Green at Fifteen? How 15-year-olds Perform in Environmental Science in PISA 2006. Paris: OECD Publishing. URL: https://www.oecd.org/pisa/pisaproducts/42467312.pdf

${ }^{73}$ Schulz, W., Ainley, J., Fraillon, J., Kerr, D. and Losito, B. (2010) ICCS 2009 International Report: Civic Knowledge, Attitudes, and Engagement Among Lower-secondary School Students in 38 countries. Amsterdam: International Association for the Evaluation of Educational Achievement. URL: https://heefa.net/files/ICCS 2009 International Report.pdf 
брати участь у відкритих, відповідних і ефективних взаємодіях з іншими людьми з різних верств суспільства на основі взаємної поваги до людської гідності (OECD, 2016: 4) 74 .

Когнітивний тест, розроблений за сприяння країн-членів ОЕСD і експертів-консультантів, дозволяє оцінити знання і розуміння молодими людьми глобальних проблем, їх міжкультурні знання і розуміння, а також навички аналітичного і критичного мислення. Крім того, в анкеті для учнів будуть використовуватися дані, що повідомляються ними самими, для аналізу таких навичок, як здатність шанобливо, належним чином і ефективно взаємодіяти і демонструвати співчуття і гнучкість, а також такі відносини, як відкритість по відношенню до людей з інших культур, повагу до культурної інакшості (cultural otherness), глобальний світогляд і відповідальність (OECD, 2016: 6). Цей тест «вперше пропонує всебічний огляд успіху систем освіти в оснащенні молодих людей для підтримки розвитку мирних, різноманітних спільнот» (OECD, 2016: 3) 75 .

PISA і інші широкомасштабні оцінки, такі як Міжнародне дослідження з освіти в області цивільних прав і громадянства (ICCS, 2016) ${ }^{76}$, можуть зробити важливий внесок в краще розуміння розвитку результатів навчання в області ESD і в збільшення вкладу ESD в якісну освіту.

Міжнародні оцінки показників навчання в рамках Освіти для стійкого розвитку, рівно як і тести, спрямовані на оцінку вибору рішень і дій, пов'язаних зі стійкістю, можуть бути залучені у якості засадничого досвіду для розроблення відповідної системи оцінювання в Україні. Оцінка і оцінювання на індивідуальному рівні можуть служити в Освіті для стійкого розвитку (ESD) кільком цілям, а саме:

- Збір інформації та реєстрація прогресу і досягнень учнів щодо очікуваних результатів навчання;

- Інформування про прогрес учнів, визначення сильних сторін і використання цієї інформації для визначення цілей навчання;

- Отримання зворотного зв'язку про успіхи процесів викладання та навчання, щоб допомогти планувати, впроваджувати і покращувати ці процеси;

- у формальній освіті прийняття керівництвом рішень про атестацію учнів і про академічний та професійний вибір.

Є багато методів оцінки результатів навчання. Використовуваний підхід буде залежати від контексту (наприклад, особливостей системи освіти) і від того, як здійснюється ESD (наприклад, у формальній освіті Освіта для стійкого розвитку (ESD) надається в рамках навчальної програми або в рамках певного предмета або іншим чином). Методи оцінки мають бути приведені у відповідність із цілями навчання і методами викладання і навчання. 3 огляду на різноманітність цілей навчання і компетентностей, оцінка навчання в рамках ESD, швидше за все, буде включати в себе ряд методів.

Дуже важливо, щоб методи, використовувані для оцінки ESD, виходили за рамки перевірки фактичних знань, щоб також оцінювалися компетентності учнів. Оцінка розвитку компетентностей в області ESD поки що залишається серйозною проблемою, позаяк багато ще належить зробити для операціоналізації та моделювання компетентностей в області стійкості. Інша проблема полягає в оцінці змін в компетентностях та інших результатів навчання з плином певного проміжку часу. В цьому відношенні багатообіцяючими $\epsilon$ довгострокові дослідження, котрі також можуть бути корисними для вивчення впливу загальноінституціональних підходів до ESD.

Оскільки широко поширеними є трансформативні застосування ESD, викладачі мають передбачати більш широкі цілі оцінювання. Вони мають вийти за рамки використання оцінки як виключно оцінки самого навчання і перейти до використання форми оцінки для навчання і форми оцінки як навчання. Поєднання традиційних методів оцінки і більш рефлексивних підходів, таких як самооцінка і оцінка з боку однолітків, дозволяє педагогам отримувати уявлення учнів про їхні особисті трансформації, підвищення їх здатності до критичних досліджень, а також про залучення їх громадянської активності , поміж іншим. Зворотній зв'язок від викладачів, зворотний зв'язок від однолітків і самооцінка (наприклад, за допомогою використання рефлексивних журналів або портфоліо) дозволяють учням контролювати свої власні процеси навчання і визначати можливі напрямки для його покращення.

Крім оцінки результатів навчання, важливо проводити постійний моніторинг та оцінку якості програм ESD. Вони можуть бути спрямовані на програмні аспекти (наприклад, очікування від навчання, ресурси,

${ }^{74}$ OECD (2016) Global Competency for an Inclusive World. www.oecd.org/pisa/aboutpisa/Global-competency-for-an-inclusiveworld.pdf (accessed 17 May 2017).

75 OECD (2016) Global Competency for an Inclusive World. www.oecd.org/pisa/aboutpisa/Global-competency-for-an-inclusiveworld.pdf (accessed 17 May 2017).

${ }^{76}$ Див. $\underline{\text { http://iccs.iea.nl }}$ 
компетентності викладання і навчальне середовище), процеси (наприклад, практики викладання, навчальні ресурси, активність учнів), результати (наприклад, знання, компетентність, цінності і погляди і трансформативний ефект) і на враховування контексту.

Зусилля по проведенню ефективного оцінювання програм ESD мають бути по можливості інтегровані в існуючі методи оцінювання. Учасники оцінювання мають приділяти пильну увагу ряду факторів. Мають бути чітко визначені цілі і індикатори оцінювання (наприклад, стан, сприяння і результати), необхідно враховувати характер учасників навчального процесу та його контекст, а також необхідно визначити вид інформації, яка надає прийнятні докази і методи збору даних.

Результати оцінки програми можуть використовуватися для різних цілей:

- Виявлення програмних обмежень;

- Визначення конкретних напрямів для поліпшення,

- Отримання інформації про місцеві, національні та міжнародні тенденції і результати;

- Оцінка ефективності програми,

- Сприяння відповідальності і прозорості.

Моніторинг та оцінка мають бути основою доказів для забезпечення інвестування в Освіту для стійкого розвитку, а також для рефлексивної взаємодії з ESD як новим процесом переорієнтації освіти. Тому вкрай важливо розробити систему показників, яка встановлює стандарти для результатів навчання в рамках Освіти для стійкого розвитку. 


\section{Ключові компетентності для викладачів ESD}

Повноважними агентами змін являються педагоги, здатні забезпечити таку реакцію освіти, яка необхідна в контексті стійкого розвитку. Їх знання і компетентність мають вирішальне значення для реструктуризації освітніх процесів і навчальних закладів в напрямку стійкості.

Педагогічна освіта має вирішити цю проблему, переорієнтувавшись на ESD, як того вимагають міжнародні декларації, такі як Стратегія освіти в інтересах стійкого розвитку (UNECE, 2005) ${ }^{77}$ і Боннська декларація (UNESCO, 2009) ${ }^{78}$, а також різні документи з політики у галузі освіти, опубліковані на національному рівні. Моніторинг та оцінка Десятиліття освіти в інтересах стійкого розвитку (DESD) виявили багато хороших прикладів того, як інтегрувати ESD в педагогічну освіту. Вони також виявили, що підтримка вчителів є ключовою умовою успішної адаптації і реалізації ESD (UNESCO, 2014) ${ }^{79}$.

Однак зусилля з підготовки вчителів до впровадження ESD $\in$ недостатніми. Необхідна додаткова робота для переорієнтації педагогічної освіти на підхід до ESD з точки зору як змісту, так і методів викладання і навчання. 3 цієї причини Пріоритетний напрямок діяльності 3 Глобальної програми дії (Priority Action Area 3 of the GAP) полягає у зміцненні потенціалу викладачів. Одним із запропонованих дій $є$ включення ESD в програми підготовки вчителів до і після завершення педагогічної освіти в вузах (UNESCO, 2014b) ${ }^{80}$.

Щоб вчителі були достатньо підготовлені для сприяння ESD, вони мають оволодіти ключовими компетентностями у галузі стійкого розвитку, включаючи знання, навички, погляди, цінності, мотивацію і відданість цілям стійкого розвитку. Однак, на додаток до загальних компетентностей у галузі стійкого розвитку, їм також необхідні компетентності в області ESD, які можна охарактеризувати як здатність учителя допомагати людям опановувати компетентності для стійкого розвитку за допомогою ряду інноваційних методів викладання і навчання.

\section{Навчальні цілі для вчителів в Освіті для стійкого розвитку ${ }^{81}$ :}

- Знати про стійкий розвиток і пов'язані з ним теми і проблеми;

- Розуміти дискурс і практику ESD в місцевому, національному та глобальному контексті;

- Виробити комплексне бачення ключових проблем і завдань з урахуванням соціальних, екологічних, економічних і культурних аспектів з точки зору принципів і цінностей стійкого розвитку;

- Виробити дисциплінарне, міждисциплінарне і трансдисциплінарне бачення щодо проблеми глобальних змін і їх локальних проявів;

- Рефлексувати над проблемами, що стоять перед просуванням концепту стійкого розвитку, і над важливістю своєї галузі знань для сприяння стійкому розвитку та своєї власної ролі в цьому процесі;

- Рефлексувати над динамікою формального, неформального та інформального навчання з метою стійкого розвитку та застосуванням цих знань у своїй професійній діяльності;

- Розуміти те, що культурне розмаїття, гендерна рівність, соціальна справедливість, захист навколишнього середовища і розвиток особистості $€$ невід'ємними елементами ESD і те, як вони можуть стати частиною освітнього процесу;

- Використовувати на практиці орієнтовану на дію трансформативну педагогіку, яка залучає учнів в процеси колективного, системного, творчого та інноваційного мислення і дії в контексті місцевих громад та повсякденного життя учнів;

- Виступати у якості агента змін в процесі навчання персоналу і учнів навчального закладу для просування школи в напрямку стійкого розвитку;

77 UNECE (United Nations Economic Commission for Europe) (2005) UNECE Strategy for Education for Sustainable Development. Geneva: UNECE. URL: www.unece.org/fileadmin/DAM/env/documents/2005/

cep.ac.13.2005.3.rev.1.e.pdf (accessed: 17 May 2017)

78 UNESCO (2009) Bonn Declaration.Paris: UNESCO. www.desd.org/ESD2009 BonnDeclaration080409.pdf (accessed 17 May 2017).

${ }^{79}$ UNESCO (2014) Shaping the Future We Want. UN Decade of Education for Sustainable Development (2005-2014). Final Report.

Paris: UNESCO. URL: http://unesdoc.unesco.org/images/0023/002301/230171e.pdf

(accessed 17 May 2017).

${ }^{80}$ UNESCO (2014) UNESCO Roadmap for Implementing the Global Action Programme on Education for Sustainable Development.

Paris: UNESCO. URL: http://unesdoc.unesco.org/images/0023/002305/230514e.pdf

(accessed 17 May 2017).

${ }^{81}$ UNESCO (2017) Education for Sustainable Development Goals. Learning Objectives. Paris: UNESCO. URL:

http://unesdoc.unesco.org/images/0024/002474/247444e.pdf (accessed 17 May 2017). 
- Визначати місцеві можливості навчання, пов'язані зі стійким розвитком і вибудовувати відносини співпраці;

- Визначати якість і оцінювати оволодіння учнями наскрізними компетентностями в області стійкості і конкретні результати навчання, пов'язані зі стійкістю.

Ці цілі більш докладно описані в ряді заснованих на компетентностях моделей для викладачів в області ESD. Ключові приклади включають в себе модель $\mathrm{CSCT}^{82}$, модель UNECE ${ }^{83}$, модель КОM-ВіNE ${ }^{84}$ і підхід, розроблений Bertschy, Künzli and Lehmann (2013) ${ }^{85}$. Ми рекомендуємо програми педагогічної освіти розробляти відповідно до цих стандартів.

Модель UNECE (2012) стосується всіх педагогів у всіх видах освіти і умовах навчання і розділена на чотири області:

1. навчання знанням (викладач розуміє ...),

2. навчання виконанню (педагог здатний ...),

3. навчання жити разом (педагог працює з іншими так, щоб ...)

4. навчання бути вчителем (педагог - це той, хто ...).

Моделі CSCT, UNECE і KOM-BiNE засновані

- на взаєминах між учителями і суспільством;

- на їх цінностях, поглядах і поведінці по відношенню до стійкості;

- на їх участі у стійкому розвитку суспільства.

Для порівняння, підхід Берчі (Bertschy), Кюнцлі (Künzli) і Лемана (Lehmann) зосереджений на професійному контексті, зокрема, на фундаментальних знаннях, уміннях і навичках, якими повинні володіти викладачі, щоб викладати ESD в аудиторії. Однак такий підхід викликає питання про те, чи можуть викладачі, які в певній мірі не погоджують свої власні цінності і поведінку з ідеєю стійкого розвитку, працювати зі студентами з питань стійкості.

Щоб сприяти розвитку компетентностей в області ESD в педагогічній освіті, необхідно внести зміни в зміст і структуру підготовки вчителів до і після завершення навчання у закладі вищої освіти. Програми педагогічної освіти повинні мати фундаментальну орієнтацію на ESD. Предметні дисципліни, предметна дидактика, педагогічні науки і орієнтовані на практику дослідження повинні включати в себе методологічні принципи і предметні знання з ESD.

\section{Можливі модулі навчальної програми для вчителів з ESD}

Основні концепти стійкого розвитку з місцевої, національної та міжнародної точок зору:

- Концепти ESD з місцевої, національної та міжнародної точок зору;

- Дисциплінарне, міждисциплінарне і трансдисциплінарне бачення ключових прикладів проблем стійкості;

- Проектно-орієнтована робота над конкретними проблемами місцевого, національного і глобального значення у співпраці з навчальними закладами та іншими (місцевими) партнерами;

- Заснований на дослідженнях аналіз процесів ESD в різних навчальних закладах (наприклад, в школах, коледжах, університетах або неформальних навчальних закладах);

- Практичний досвід використання підходів до ESD і пов'язана з ним критична рефлексія.

Навчання на основі реальних соціальних проблем в місцевому контексті вимагає співпраці із зовнішніми партнерами. Таким чином, модулі повинні враховувати необхідність доступу до зовнішніх

\footnotetext{
${ }^{82}$ Sleurs, W. (2008) Competencies for ESD (Education for Sustainable Development) teachers. A framework to integrate ESD in the curriculum of teacher training institute. Brussels: CSCT. URL:

www.unece.org/fileadmin/DAM/env/esd/inf.meeting.docs/EGonlnd/8mtg/CSCT\%20Handbook Extract.pdf

(accessed 17 May 2017).

83 UNECE (2012) Learning for the Future: Competences in Education for Sustainable Development. Geneva: UNECE. URL: www.unece.org/fileadmin/DAM/env/esd/ESD_Publications/Competences_Publication.pdf

(accessed: 17 May 2017).

${ }^{84}$ Rauch, F. and Steiner, R. (2013) Competences for education for sustainable development in teacher education. CEPS Journal, 3 : 9-24. URL: https://www.pedocs.de/volltexte/2013/7663/pdf/cepsj 200131 Rauch Steiner Competences for education for sustainable developme nt.pdf

${ }^{85}$ Bertschy, F., Künzli, C. and Lehmann, M. (2013) Teachers' competencies for the implementation of educational offers in the field of education for sustainable development. Sustainability, 5: 506. URL: https://www.mdpi.com/2071-1050/5/12/5067/htm
} 
партнерів (наприклад, співтовариств, неформальних навчальних закладів і мереж ESD) і включати в себе можливості для проектно-орієнтованого співробітництва. Крім того, ESD вимагає інтернаціоналізації як елемента педагогічної освіти, зокрема, шляхом проведення міжнародних дискусій з ESD і дискусій про культурне різноманіття як невід'ємних компонентів цих модулів. Це означає, що студентам має бути надана можливість навчатися за кордоном, щоб сприяти придбанню практичного досвіду.

Щоб краще інтегрувати ESD в педагогічну освіту, розроблення змісту і організація програм педагогічної освіти мають включати в себе участь ключових зацікавлених сторін, таких як студенти, викладачі, місцеві неурядові організації та експерти з ESD. Для сприяння інноваціям вкрай важливо, щоб навчальні заклади мали необхідні структурні умови, а також свободу для участі в загальноінституціональних процесах навчання.

Оскільки навчання в педагогічних ЗBО як і раніше не включає в себе ESD, багатьом вчителям необхідно мати доступ до спеціалізованого навчання з цього питання. Це відкриє можливості для придбання необхідних знань і навичок для участі в процесі стійкого розвитку. Крім того, професійний розвиток $\epsilon$ передумовою переорієнтації освітніх процесів і навчальних закладів. Відповідно, вкрай важливо, щоб професійний розвиток в області ESD був доступним більш ніж окремим викладачам з одного і того ж навчального закладу і визнавався освітніми системами при розгляді заяв про прийом на роботу, просування по службі і так далі. Актуальною для України $є$ організація національних та регіональних експертних центрів ESD, які можуть також розширювати можливості для професійного розвитку та консультативних послуг, використовуючи потенціал урядових і неурядових організацій, а також університетів та інших закладів вищої освіти. 


\section{Ключові теми в освіті для стійкого розвитку}

Хоча надбання компетентностей у галузі стійкого розвитку лежить в основі освіти ESD, вибір тем і контенту, що використовуються для розвитку цих компетентностей, не є довільним. Ключові теми ESD мають вирішальне значення для процесів стійкого розвитку на місцевому та глобальному рівні і їх вибір має значення для майбутнього. Студентам мають бути доступні диференційовані знання за темами з різних областей, щоб вони могли аналізувати цю інформацію з альтернативних точок зору, включаючи трансдисциплінарний рівень знання і таким чином забезпечуючи інклюзивність контенту навчання. Але завжди у цих темах імпліцитно повинна міститися можливість учнів діяти відповідно до принципу «знання+дія», який відповідає компетентнісному підходу ${ }^{86}$.

Визначаючи комплексні теми навчання і дослідження, слід використовувати міжнародний досвід, зафіксований у документах впливових організацій і заходів, і кращий досвід окремих навчальних закладів як показових у запровадженні ESD. Області діяльності, необхідні для сприяння стійкому розвитку, були визначені низкою наукових досліджень, суспільним досвідом і відповідними дискусіями. Ці області діяльності є тематичними пріоритетами для ESD. Цілі стійкого розвитку (SDGs) визначають 17 таких областей діяльності, про які було зазначено вище.

У Дорожній карті по здійсненню Глобальної програми дій названі наступні ключові галузі стійкого розвитку, які мають бути першочерговими у визначенні тем в Освіті для стійкого розвитку: зміна клімату, біорізноманіття, зниження ризику катастроф та стійке споживання і виробництво (UNESCO, 2014) ${ }^{87}$.

У Боннській декларації наголошується на необхідності навчитися «вирішувати різні пріоритетні проблеми, зокрема, проблеми води, енергії, змін клімату, зменшення небезпеки стихійних лих і ризиків, втрати біорізноманіття, продовольчі кризи, ризики для здоров'я, соціальної вразливості і відсутність безпеки» (UNESCO, 2009: para. 7) ${ }^{88}$. Угоди і програми, такі як Порядок денний на XXI століття, Рамкова конвенція Організації Об'єднаних Націй про зміну клімату, Конвенція про біологічне різноманіття, Хіогська рамкова програма дій на 2005-2015 роки: забезпечення стійкості народів і громад до стихійних лих і Програма зі стійкого способу життя, а також Освітня програма в рамках 10-річної програми зі стійкого споживання та виробництва на 2012-2021 роки містять додаткову інформацію щодо важливих тем Освіти для стійкого розвитку, включаючи ключові теми соціально-гуманітарного блоку проблем (забезпечення миру, безпеки, прав людини, соціальної справедливості) як глобально інтернаціональних, вирішення яких можливе лише на засадах формування глобального громадянського суспільства.

Ці теми визначають повсякденне життя людей різного віку, які живуть в різних життєвих умовах, в різних країнах та мають різний досвід вирішення таких проблем. Ці теми є складними і різноманітними. Проте, вони надають можливість працювати з людьми таким чином, щоб центральним об'єктом Освіти для стійкого розвитку (ESD) став потенціал для трансформації.

На часі вирішення складних завдань для освітян України: на основі Цілей стійкого розвитку (SDGs) та пов'язаних з ними реальних проблем та їх вирішення на шляху до глобального миру необхідно розробити ключові теми в області Освіти для стійкого розвитку: зміна клімату, біорізноманіття, стійке виробництво і споживання, права людини, глобальна справедливість, зниження ризику катастроф та скорочення бідності, формування глобального громадянства тощо. В обґрунтуванні кожної теми має бути представлена їі актуальність для стійкого розвитку та зв'язок з Цілями стійкого розвитку (SDGs). Крім того, необхідно представити в рамках описаних вище підходів можливе розмаїття педагогічних методів і форм викладання і навчання, релевантних цілям і головній меті трансформативного навчання («громадяни стійкості»), які дозволять учням розуміти ключові теми, виробити своє ставлення до них на індивідуальному і груповому рівні і брати активну участь у сприянні стійкому розвитку в цих тематичних областях. Учні мають працювати над досягненням цілей в когнітивній, соціально-емоційній і поведінковій областях.

${ }^{86}$ Rieckmann, M. (2018) Learning to transform the world: key competencies in Education for Sustainable Development. In: Leicht, A.; Heiss, J.; Byun, W. J. (eds) (2018) Issues and trends in Education for Sustainable Development, UNESCO Publishing. URL: https://unesdoc.unesco.org/ark:/48223/pf0000261445

${ }^{87}$ UNESCO (2014) UNESCO Roadmap for Implementing the Global Action Programme on Education for Sustainable Development. Paris: UNESCO. URL: http://unesdoc.unesco.org/images/0023/002305/230514e.pdf

(accessed 17 May 2017).

${ }^{88}$ UNESCO (2009) Bonn Declaration. Paris: UNESCO. URL: www.desd.org/ESD2009 BonnDeclaration080409.pdf (accessed 17 May 


\section{Інтеграція тем стійкого розвитку в освітні програми і практики}

Вибір тем важливий для розвитку сприйняття, знань і компетентностей, пов'язаних зі стійким розвитком, проте вирішальними $є$ точки зору, з яких ці теми розглядаються. Ціннісна основа стійкого розвитку формує різні точки зору щодо цих тем і пропонує можливості для орієнтації в процесі спілкування і розвитку нормативної компетентності. Тим часом, стратегії стійкості (наприклад, ефективність, комплексність, збалансованість, узгодженість і достатність) відкривають плідні перспективи для аналізу і пошуку можливостей для трансформації. При цьому мається на увазі використання як регіональних, так і глобальних перспектив. Таким чином, у якості педагогічних концепцій в освітніх процесах для стійкого розвитку можуть бути використані різні перспективи з дискурсу стійкості.

Нарешті, Освіта для стійкого розвитку має створити простір, в якому учні можуть ознайомитися 3 ключовими питаннями стійкого розвитку і виробити необхідні компетентності для їх вирішення.

\section{Якісна освіта як Освіта для стійкого розвитку}

Відносини між якісною освітою і Освітою для стійкого розвитку (ESD) як унікальні і важливі (читай органічні) взаємозв'язки набули релевантності в 2005 році завдяки проголошенню ООН Декади освіти для стійкого розвитку (DESD) і стали набирати обертів. Зростаюча обізнаність щодо таких відносин сприяла трансформації освітньої політики і підходів до навчання в країнах усього світу. Ще більше уваги стало приділятися зростанню значення більш тісних зв'язків між поліпшенням якості освіти і Освіти для стійкого розвитку в середині декади після всесвітньої конференції ЮHЕСКО з ESD, що відбулася в 2009 році в Бонні (Німеччина). Боннська декларація свідчить: «Освіта для стійкого розвитку задає новий напрям освіти і навчання для всіх. Вона сприяє якісній освіті і поширюється на всіх людей. Вона заснована на цінностях, принципах і практиці, необхідних для ефективного реагування на поточні та майбутні проблеми» (UNESCO, 2009b, para. 6) ${ }^{89}$.

У Айті-Нагойській декларації, яка ознаменувала закінчення Декади, також було підтверджено «зростаюче міжнародне визнання Освіти для стійкого розвитку як невід'ємного і трансформативного елемента інклюзивної якісної освіти і навчання протягом усього життя і інструменту стійкого розвитку» (UNESCO, 2014, para.6) ${ }^{90}$.

Цей унікальний зв'язок між якісною освітою і Освітою для стійкого розвитку вплинув на загальне розуміння якості освіти. Цілі розвитку на тисячолітяя, і Дакарська програма дій - Освіта для всіх (UNESCO, 2000) в основному розглядали якісну освіту з точки зору вимірних результатів навчання, компетентностей і національних стандартів. Однак погляд ESD на якісну освіту стосується навчання протягом усього життя і розвитку навичок і цінностей учнів з акцентом на їх застосування для вирішення глобальних проблем стійкості.

Збагачене бачення якісної освіти в даний час розглядається як таке, що включає в себе релевантність Освіти впродовж життя, ії цілі, методи і зміст навчання. Як зазначається в документах UNESCO, освітяни згодні з тим, що якісна освіта для стійкого розвитку підсилює почуття відповідальності людей як глобальних громадян і краще їх готує до того світу, який вони успадкують (UNESCO, 2014: 28) ${ }^{91}$.

3 початку проголошеної ООН Декади освіти в інтересах стійкого розвитку (DESD), ESD розвивалася за багатьма напрямками, і не в останню чергу завдяки зусиллям багатьох країн щодо трансформування своєї освітньої політики з метою розвитку ESD і якісної освіти. Увага до якісної Освіти впродовж життя не спрямована на те, щоб знецінити основоположні ключові компетентності, такі як грамотність і вміння рахувати. Швидше, така позиція містить в собі критику застарілого філософського положення про те, що основною метою освіти $€$ передача знань, і замість цього стверджує, що освіта має забезпечувати кожному поколінню здібності та навички для поліпшення роботи попередніх поколінь і подолання найбільш нагальних проблем свого часу. Такий якісний підхід до ESD поставив перед політиками у галузі освіти, керівниками

${ }^{89}$ UNESCO (2009) Bonn Declaration. Paris: UNESCO. URL: www.desd.org/ESD2009 BonnDeclaration080409.pdf (accessed 17 May 2017).

90 UNESCO (2014) UNESCO Roadmap for Implementing the Global Action Programme on Education for Sustainable Development. Paris: UNESCO. URL: http://unesdoc.unesco.org/images/0023/002305/230514e.pdf

(accessed 17 May 2017).

${ }^{91}$ UNESCO (2014) Shaping the Future We Want. UN Decade of Education for Sustainable Development (2005-2014). Final Report. Paris: UNESCO. URL: http://unesdoc.unesco.org/images/0023/002301/230171e.pdf

(accessed 17 May 2017). 
закладів навчання і педагогами завдання переглянути характер і цілі освіти для поліпшення становища дітей та молоді.

Зміни у політиці забезпечення якості освіти можна підтвердити прикладами з діяльності UNESCO.

У 2013 році 68 країн відповіли на анкету ЮНЕСКО про їх найбільші досягнення в області Освіти для стійкого розвитку протягом Декади. 21 країна засвідчила про свій досвід включення ESD в політику або навчальну програму, а ще 19 країн відзначили розробку національної стратегії ESD. B цілому на активну політику запровадження Освіти для стійкого розвитку припадає 57 відсотків отриманих відповідей, в той час як решта відповідей вказали на те, що найбільшим досягненням цих країн була реалізація конкретних проектів (ЮНЕСКО, 2013) $)^{92}$.

Хоча були докладені суттєві зусилля з просування політики в області ESD, вони є далеко не однаковими у світі, і багато країн все ще шукають ефективні способи зміцнення політики в області ESD та якісної освіти. На жаль, Україна в області запровадження політики якісної освіти як Освіти для стійкого розвитку поки що перебуває на маргінесі глобальних (радше глокальних) зусиль у вирішенні цього питання. Усвідомлення необхідності і нагальності концентрації уваги і дії на спрямуванні освітньої політики і практики навчання відповідно до глобальних тенденцій стійкого розвитку і формування глобального громадянства, постає як важлива просвітницька мета і національний пріоритет розвитку освіти України. П̈ї реалізація можлива як результат спільної дії освітян, управлінців, громадських організацій, зацікавленого бізнесу, мілітантів стійкого розвитку і всієї української спільноти.

Якісна освіта для стійкого розвитку базується на релевантності освіти по відношенню до сьогоднішніх світових і глобальних проблем з метою формування компетентностей, тобто знань, навичок і підходів, щоб ефективно реагувати на такі виклики і забезпечити процвітання для сьогоднішнього і для майбутніх поколінь.

Часто обговорення ESD, особливо пов'язані з освітнім контентом, обмежуються лише увагою до стійкого розвитку. Хоча аспекти стійкості для ESD мають дуже важливе значення, їх надмірне акцентування іноді шкодить такому важливому компоненту, який спирається на довгу історію прогресивних теорій освіти. ESD не представляє собою «освіту» за спеціалізованою темою стійкого розвитку; скоріше, вона складається із комплексу спеціалізованих педагогічних освітніх програм, які спрямовані на інтеграцію і рішення широкого кола питань крізь призму стійкого розвитку. Педагогіка і підходи до навчання, включені в ESD, спираються на більш ранні роботи у галузі екологічної освіти, освіти з питань глобального громадянства, проектного навчання і навчання на основі досвіду. Унікальним аспектом, схопленим ESD, є його цілісна компоновка і застосування цих різних освітніх теорій і педагогік з точки зору трансформативного навчання. Реальна потреба полягає у тому, щоб перейти від передавального до трансформативного навчання, але це, в свою чергу, вимагає трансформованої освітньої парадигми. Зміна парадигми сама по собі є трансформативним процесом навчання ${ }^{93}$.

Міжнародна комісія з освіти для XXI століття (International Commission on Education for the 21st Century) під головуванням Жака Делора (Delors) з 1993 по 1996 рік провела серію досліджень і глобальних консультацій щодо того, як можна реформувати освіту, щоб вона відповідала цій меті і вирішувало завдання майбутнього століття. У заключному звіті «Навчання: Скарб всередині» (1996) освіта проголошується у якості «основного засобу» для досягнення соціальних трансформацій шляхом «стимулювання більш глибокої і більш гармонійної форми людського розвитку і, таким чином, скорочення бідності, відчуження, невігластва, пригнічення і воєн» (Delors, 1996: 13) ${ }^{94}$. У доповіді переконливо стверджується, що освіта має бути стимулом і джерелом безперервного навчання протягом усього життя і створення суспільства, що навчається, заснованого на придбанні, оновленні та використанні знань.

У звіті також стверджується, що для того, щоб підняти освіту до рівня, відповідного викликам XXI століття, вона має бути організованою навколо чотирьох стовпів:

1. Вчитися пізнавати, тобто набувати знарядь розуміння;

2. Вчитися діяти, щоб мати можливість творчо діяти у своєму середовищі;

92 UNESCO (2013) Concept note on the post-2015 education agenda. URL: http://www.unesco.org/new/fileadmin/MULTIMEDIA/HQ/ED/ED_new/pdf/UNESCOConceptNotePost2015_ENG.pdf

${ }^{93}$ Sterling, S. (2016) A commentary on education and Sustainable Development Goals. Journal of Education for Sustainable Development, 10(2): 208-213. URL: https://www.researchgate.net/publication/308816595 A Commentary on Education_and Sustainable Development_Goals

${ }^{94}$ Delors, J. (1996) Education: the necessary utopia. Learning: The Treasure Within. Paris: UNESCO, 11-33. 
3. Вчитися жити разом, щоб бути учасником і співпрацювати з іншими людьми в усіх видах людської діяльності; а також

4. Вчитися бути, найважливіший результат, який випливає з трьох попередніх пунктів (International Commission on Education for the 21st Century, 1996: 86) ${ }^{95}$.

По мірі розвитку концепту ESD освіта стала розглядатися як засіб для досягнення цих чотирьох опорних цілей навчання, а також як допомога для пояснення п'ятого стовпа:

- Вчитися трансформувати самих себе і суспільство, наділяти людей цінностями і здібностями брати на себе відповідальність за створення і користування благами стійкого майбутнього (Schaeffer, 2006) ${ }^{96}$.

Протягом Декади освіти для стійкого розвитку (DESD) всі п'ять стовпів були адаптовані для безпосередньої відповідності конкретним аспектам ESD, але, в цілому, ці п'ять стовпів навчання як і раніше служать для визначення основних концептуальних результатів, яких має досягти освіта в цілому.

Загальна мета перебудови освіти на основі підходу, орієнтованого на учнів, полягає в цілісному розвитку людей, з тим щоб вони могли активно використовувати свої знання, навички та цінності в реальних ситуаціях для поліпшення якості життя і добробуту для себе, своїх родин, своєї спільноти і суспільства в цілому. На додаток до навчання, орієнтованого на учнів, принципи навчання ESD можна розглядати як пряму протилежність принципам традиційних підходів до освіти (Didham and Ofei-Manu, 2012) ${ }^{97}$. Вони включають в себе захоплених учнів (а не абстрактних спостерігачів), спільне і соціальне навчання (а не індивідуалістичне і конкурентне навчання), навчання, засноване на рішенні проблем і практичне навчання, орієнтоване на досвід (а не запам'ятовування інформації і механічне заучування), а також критичне усвідомлення і рефлексивність, щоб створювати особистісні конструкції знань (а не раціоналістичну передачу фактів). Загальна структура ESD охоплює і об'єднує велику кількість концептів, теорій, політичних приписів і практичних методів та інструментів, спрямованих на реформування систем освіти з метою забезпечення стійкого розвитку.

Ще у 2009 році в огляді Декади освіти для стійкого розвитку (DESD) було зазначено, що ESD реалізується в рамках двох різних педагогічних інтерпретацій:

1. ESD як засіб передачі «потрібних» знань, цінностей і поведінки; а також

2. ESD як засіб розвитку здібностей і можливостей людей вирішувати проблеми для досягнення стійкості, як засіб розвитку людського креативного потенціалу самостійно визначати альтернативні способи життя (UNESCO, 2009: 27) ${ }^{98}$.

Хоча ці інтерпретації істотно розрізняються, вони не $є$ несумісними. Навіть якщо дотримуватися другого тлумачення, потреба ESD у конкретних знаннях, навичках і цінностях залишається актуальною. У тій же доповіді також підкреслюється інший погляд, який має важливе значення для політики у галузі освіти, який розглядає ESD як засіб підвищення якості базової освіти, переорієнтації існуючих освітніх програм і підвищення рівня обізнаності Щоб узгодити ці інтерпретації, тобто розуміння ESD як засобу «передачі» потрібних знань і навичок з розумінням ESD як засобу розвитку здібностей людей і підвищення якості освіти, важливо визначити роль, яку відіграють у формуванні нового бачення ESD педагогіка і методологія навчання. Багато в чому подібно до більш широкого концепта стійкого розвитку, концепт ESD заснований не виключно на новітніх методах і підходах, а скоріше включає в себе і будується на широкому спектрі вже існуючих теорій і педагогік освіти. Структура ESD спирається на різні вже існуючі теорії освіти, в тому числі теорію практичного навчання.

Теорія практичного навчання була концептуалізована Колбом (Kolb) і колегами в 1970-і роки і спирається на роботи Дьюї (Dewey) та Піаже (Piage). Ця теорія просуває, по-перше, чотирьохетапний цикл навчання, який включає в себе конкретний досвід, рефлексивне спостереження, абстрактну концептуалізацію і активне експериментування), по-друге, теорію комунікативної дії і комунікативного розуму. Габермас (Habermas) (1981) розробив теорію комунікативної дії як засіб соціального конструювання розуму через його органічну передачу і оновлення як колективний процес, який може звільнити людей від

95 Int. Comm. on Education for the 21st Century. 1996. Learning: The Treasure Within. Paris: UNESCO.

${ }^{96}$ Schaeffer, S. (2006) Beyond 'learning to live together': The key to education for sustainable development. Presentation at the UNESCO Expert Meeting on ESD: 'Reorienting Education to Address Sustainability', 1-3 May 2006, Kanchanaburi, Thailand.

${ }^{97}$ Didham, R.J and Ofei-Manu, P. (2012) Education for Sustainable Development Country Status Reports: An Evaluation of National Implementation during the UN Decade of Education for Sustainable Development (2005-2014) in East and Southeast Asia. Hayama, Japan. URL: http://pub.iges.or.jp/modules/envirolib/view.php?docid=4140.

${ }^{98}$ UNESCO (2009) Learning for a Sustainable World: Review of Contexts and Structures for Education for Sustainable Development. Paris: UNESCO. URL: https://doi.org/10.2139/ssrn.1485401 
обмежень раціоналістичної системи. По-третье, теорію критичного праксису і критичної педагогіки Фрейре (Freire), який, починаючи з 1970 року, виступав за визнання політичної природи освіти і просував освіту як засіб для досягнення індивідами критичної свідомості. Ледвіт (Ledwith) з 2005 року застосував ці ідеї критичної педагогіки для розвитку громади та виявив, що процеси спільних дій і рефлексії (тобто критичний праксис) також можуть досягти цієї консциєнтизації), по-четверте, теорію спільного дослідження: Герон (Heron) і Різон (Reason) з 1971 року просували концепцію спільного дослідження і дослідження спільних дій як засіб переходу від «дослідження людей» до «дослідження з людьми».

Це включає в себе визнання чотирьох типів знань: пропозиціональні, практичні, досвідні і презентаційні знання (propositional, practical, experiential and presentational knowledge) в процесі спільного створення сенсу, і теорію спільноти практики (communities of practice). Лейв (Lave) і Berнер (Wegner) у 1991 і 1998 роках представили цю концепцію як засіб для розуміння того, як групи спільно навчаються осмисленими способами та краще розуміють процеси та фактори, що посилюють це навчання (Didham and Ofei-Manu, 2012: 9) ${ }^{99}$. На підставі того, що таке навчання в рамках Освіти для стійкого розвитку надає важливого значення навчальним центрам, орієнтованим на учнів, і акцентує на необхідності поступового переосмислення педагогіки, ESD може бути потужним інструментом реформування систем освіти і досягнення загального покращення якості освіти.

Сприйняття ESD змінилося і розширилося, що вплинуло на паралельні дискусії про право і потреби в якісній освіті як фундаментальній умові прогресу людства. В даний час зростає розуміння того, що якісну освіту слід розглядати в контексті загальної мети освіти як Освіти для стійкого розвитку людства (UNESCO, 2014: 21$)^{100}$.

В даний час країни розробляють і планують свої національні відповіді на ряд важливих міжнародних угод, включаючи Паризьку хартію про зміну клімату, Порядок денний у галузі розвитку на період до 2030 року (the 2030 Development Agenda) та Цілі стійкого розвитку (Sustainable Development Goals ( SDGs)). Обидва документи містять статті, в яких йдеться про важливість освіти для досягнення загальних цілей і підтримки переходу до більш стійкого суспільства та його збалансованого розвитку. Ці угоди також надають країнам широкі можливості для активізації і концентрації своїх зусиль на реалізації ESD. Що стосується SDGs 4 в галузі освіти, то вони також бачать в ESD потенціал для якісного зрушення в реформуванні і подальшому розвитку освіти. У ЮНЕСКО є чіткий мандат в Інчхонській декларації «Освіта 2030» (Education 2030 Incheon Declaration) і в Програмі дій у галузі освіти до 2030 року (Framework for Action (UNESCO, 2015)) ${ }^{101}$ на підтримку освітніх цілей стійкого розвитку.

У розвиток заявлених цілей ЮНЕСКО розробила рекомендації, які визначають ключові цілі навчання для кожної з Цілей стійкого розвитку, а також вісім основних компетентностей в області стійкості, на досягнення яких має працювати Освіта для стійкого розвитку:

- компетентність системного мислення (systems thinking competency)

- прогностична компетентність (anticipatory competency),

- нормативна компетентність (normative competency)

- стратегічна компетентність (strategic competency)

- компетентність співпраці (collaboration competency)

- компетентність критичного мислення (critical thinking competency)

- компетентність саморефлексії (self-awareness competency) 2017) $)^{102}$.

- інтегрована компетентність вирішення проблем (integrated problem-solving competency) (UNESCO,

За умови наявності відповідальності всіх країн і глобальних зусиль, спрямованих на вирішення глобальних проблем, при забезпеченні добробуту та якості життя населення світу, для людства не може бути

\footnotetext{
${ }^{99}$ Didham, R.J and Ofei-Manu, P. (2012) Education for Sustainable Development Country Status Reports: An Evaluation of National Implementation during the UN Decade of Education for Sustainable Development (2005-2014) in East and Southeast Asia. Hayama, Japan. URL: http://pub.iges.or.jp/modules/envirolib/view.php?docid=4140.

${ }^{100}$ UNESCO (2014) Shaping the Future We Want: UN Decade of Education for Sustainable Development (2005-2014) - Final Report. Paris: UNESCO.

${ }^{101}$ UNESCO (2015) Framework for Action Education 2030: Towards Inclusive and Equitable Quality Education and Lifelong Learning for All(draft). Incheon: UNESCO.

102 UNESCO (2017) Education for Sustainable Development Goals: Learning Objectives. Education 2030. Paris: UNESCO.

Issues and trends in Education for Sustainable Development. URL: https://www.unesco.de/sites/default/files/2018- 
нічого більш важливого, ніж колективне прагнення до стійкого розвитку. 3 цією метою найбільшим засобом, доступним людству, є освіта, зокрема система освіти, орієнтована на надання якісної Освіти для стійкого розвитку. Однак просування політики в області ESD не може складатися виключно із зусиль по додаванню таких тем, як Цілі стійкого розвитку, в уже перевантажену навчальну програму. Швидше, політика в області ESD має дослідити шляхи трансформування систем освіти, щоб вся система в цілому стала моделлю стійкості і надавала широкі можливості для вивчення, обговорення і усвідомлення значення і наслідків стійкого розвитку. Концепція стійкого розвитку не визначається конкретною державою або якоюсь остаточною інстанцією; це, скоріше, безперервна подорож і шлях навчання. Роль Освіти для стійкого розвитку полягає саме в тому, щоб підготувати учнів до цієї подорожі (Didham, Ofei-Manu, 2018) ${ }^{103}$.

${ }^{103}$ Didham, R.J.; Ofei-Manu, P. (2018) Advancing policy to achieve quality Education for Sustainable Development. In: Leicht, A.; Heiss, J.; Byun, W. J. (eds) (2018) Issues and trends in Education for Sustainable Development, UNESCO Publishing. URL: https://unesdoc.unesco.org/ark:/48223/pf0000261445 


\section{Висновки}

Освіта для стійкого розвитку (ESD) може допомогти у сприянні стійкому розвитку, розвиваючи наскрізні компетентності в області стійкості, необхідні для вирішення широкого кола завдань у галузі стійкого розвитку. Щоб дати людям в усьому світі можливість діяти в інтересах стійкого розвитку, всі навчальні заклади мають активно займатися питаннями стійкого розвитку і сприяти розвитку компетентностей у галузі стійкого розвитку. Отже, вкрай важливо не тільки включати в навчальні плани матеріали, пов'язані зі стійким розвитком, але також використовувати трансформативну педагогіку, орієнтовану на конкретні дії. Щоб застосувати цю педагогіку на практиці, потрібні педагоги, які не тільки знають про ESD, але і набули компетентності викладання, пов'язані з ESD, шляхом самоосвіти та участі у тренінгах.

ESD обов'язково буде продовжувати розвиватися. В даний час ЮНЕСКО за допомогою експертних симпозіумів та інших консультацій бере участь в процесі вивчення і визначення майбутнього ESD і забезпечення її відповідності мінливим глобальним, національним і місцевим умовам. Крім іншого, ESD має реагувати на мінливі умови і виникаючі тенденції, такі як визнання стійкого розвитку в якості обраного молодим поколінням способу життя, а непросто як низки екологічних або пов'язаних з цим проблем.

Стає очевидним, що ESD має вийти за рамки зосередженості на знаннях і навичках задля пропаганди цінностей і підходів, що сприяють стійкому розвитку, і надання можливості відповідальним громадянам вживати дії для здійснення змін. У світі, в якому постійно збільшується взаємозалежність, технологічні досягнення трансформують роль формальної освіти від надання знань до розвитку критичного мислення. Очікується, що технологічні рішення «старих» проблем стійкого розвитку вийдуть за рамки впливу освіти на такі прості зміни поведінки, як «виключення світла». Натомість у багатьох частинах світу ESD пов'язана 3 громадськими рухами і зростаючою переконаністю у тому, що важливим місцем трансформації є спільнота. До сих пір було досить роздумів про досягнення і недоліки ESD, і в подальшому необхідно враховувати контекстуальну релевантність ESD для країн, що розвиваються і розвинених країн. Перш за все, необхідно використовувати вікно можливостей, представлене у Порядку денному в галузі стійкого розвитку на період до 2030 року, для розширення масштабів ESD в Україні і розширення перспектив для визнання її ролі у якості наскрізного інструменту для всіх цілей в області стійкого розвитку нашої країни як частини глобального світу.

В рамках Глобальної програми дій ESD набирає обертів, і ростуть заклики до освіти сприяти переходу, необхідного для досягнення більш стійкого миру. Зацікавлені сторони у всьому світі прихильні до посилення ролі освіти і, зокрема, ESD, в досягненні стійкого розвитку. Є підстави бути впевненими, що майбутнє ESD буде ще більш багатим і ефективним, ніж його сьогодення і минуле. 


\section{Список використаних джерел}

1. Adomßent, M. and Hoffmann, T. (2013) The Concept of Competencies in the Context of Education for Sustainable Development (ESD). URL: http://esdexpert.net/assets/130314-Concept-Paper-ESD-Competencies.pdf (accessed 17 May 2017).

2. Barth, M. (2015) Implementing sustainability in higher education: learning in an age of transformation. London, Routledge.

3. Bertschy, F., Künzli, C. and Lehmann, M. (2013) Teachers' competencies for the implementation of educational offers in the field of education for sustainable development. Sustainability, 5: 506 https://www.mdpi.com/2071-1050/5/12/5067/htm

4. Brundtland Report (1987) Our Common Future: Report of the World Commission on Environment and Development, United Nations. URL: www.un-documents.net/wced-ocf.htm

5. Delors, J. (1996) Education: the necessary utopia. Learning: The Treasure Within. Paris: UNESCO, 11-33.

6. Didham, R.J and Ofei-Manu, P. (2012a) Education for Sustainable Development Country Status Reports: An Evaluation of National Implementation during the UN Decade of Education for Sustainable Development (20052014) in East and Southeast Asia. Hayama, Japan. URL:

http://pub.iges.or.jp/modules/envirolib/view.php?docid=4140.

7. Didham, R.J.; Ofei-Manu, P. (2018) Advancing policy to achieve quality Education for Sustainable Development. In: Leicht, A.; Heiss, J.; Byun, W. J. (eds) (2018) Issues and trends in Education for Sustainable Development, UNESCO Publishing. URL: https://unesdoc.unesco.org/ark:/48223/pf0000261445

8. Glasser, H. and Hirsh, J. (2016) Toward the development of robust learning for sustainability core competencies. Sustainability: The Journal of Record, 9(3): 121-134. URL:

https://wmich.edu/sites/default/files/attachments/u159/2016/2016\%20Core\%20Competencies.pdf;

9. de Haan, G. (2010) The development of ESD-related competencies in supportive institutional frameworks. International Review of Education, 56(2): 315-328. URL: https://www.researchgate.net/publication/225773272_The_development_of_ESD-

related_competencies_in_supportive_institutional_frameworks;

10.Int. Comm. on Education for the 21st Century. 1996. Learning: The Treasure Within. Paris: UNESCO.

11. Kolb, D. A. (1984) Experiential Learning: Experience as the Source of Learning and Development. Englewood Cliffs, N.J., Prentice-Hall

12.Learning Metrics Task Force (2013) Executive Summary. Toward Universal Learning: A Global Framework for Measuring Learning. Montreal and Washington, DC: UNESCO Institute for Statistics and Center for Universal Education at the Brookings Institution. URL: https://www.brookings.edu/wp-

ontent/uploads/2016/06/LMTFReport2ES_final.pdf

13.Leicht, A.; Heiss, J.; Byun, W. J. (eds) (2018) Issues and trends in Education for Sustainable Development, UNESCO Publishing. URL: https://unesdoc.unesco.org/ark:/48223/pf0000261445

14.Leicht, A.; Combes, B; Byun, W.J.; Agbedahin, A.V. (2018) From Agenda 21 to Target 4.7: the development of Education for Sustainable Development. In: Leicht, A.; Heiss, J.; Byun, W. J. (eds) (2018) Issues and trends in Education for Sustainable Development, UNESCO Publishing. URL:

https://unesdoc.unesco.org/ark:/48223/pf0000261445

15. Lotz-Sisitka, H., Wals, A.E., Kronlid, D. and McGarry, D. (2015) Transformative, transgressive social learning: rethinking higher education pedagogy in times of systemic global dysfunction. Current Opinion in Environmental Sustainability, 16: 73-80. URL: http://www.openensemble.se/wpcontent/uploads/2018/08/lotzwalskronlidmcgarytransgressivesociallearning.pdf

16. Mezirow, J. (2000) Learning as transformation: critical perspectives on a theory in progress. San Francisco, Jossey-Bass.

17.Nussbaum, M.C. (2010) Creating Capabilities: The Human Development Approach. Cambridge: Belknap Press of Harvard University Press. URL:

https://www.hup.harvard.edu/catalog.php?isbn=9780674072350\&content=reviews

18. OECD (2009) Green at Fifteen? How 15-year-olds Perform in Environmental Science in PISA 2006. Paris: OECD Publishing. URL: https://www.oecd.org/pisa/pisaproducts/42467312.pdf

19. OECD (2015) Skills for Social Progress: The Power of Social and Emotional Skills. Paris. OECD. URL: https://www.oecd.org/education/skills-for-social-progress-9789264226159-en.htm 
20. OECD (2016) The Education 2030 Conceptual learning framework as a tool to build common understanding of complex concepts, $4^{\text {th }}$ Informal working Group on the Future of Education and skills: OECD Education 2030, Beijing, 2016. URL:

http://www.oecd.org/education/2030-project/contact/OECD_Learning_Compass_2030_Concept_Note_Series.pdf

21.OECD (2016) Global Competency for an Inclusive World. www.oecd.org/pisa/aboutpisa/Globalcompetency-for-an-inclusive-world.pdf (accessed 17 May 2017).

22. Open Working Group on Sustainable Development Goals (2013) Concluding Remarks of Co-Chairs, OWG4, 19 June 2013. URL:

http://sustainabledevelopment.un.org/content/documents/3693cochairsconcluding.pdf

23. Rauch, F. and Steiner, R. (2013) Competences for education for sustainable development in teacher education. CEPS Journal, 3: 9-24. URL:

https://www.pedocs.de/volltexte/2013/7663/pdf/cepsj_20013_1_Rauch_Steiner_Competences_for_education_fo r_sustainable_development.pdf

24. Rieckmann, M. (2012) Future-oriented higher education: which key competencies should be fostered through university teaching and learning? Futures, 44(2): 127-135. URL:

https://www.researchgate.net/publication/232364850_Future-

oriented_higher_education_Which_key_competencies_should_be_fostered_through_university_teaching_and_le arning

25. Rieckmann, M. (2018) Learning to transform the world: key competencies in Education for Sustainable Development. In: Leicht, A.; Heiss, J.; Byun, W. J. (eds) (2018) Issues and trends in Education for Sustainable Development, UNESCO Publishing. URL: https://unesdoc.unesco.org/ark:/48223/pf0000261445

26. Rychen, D.S. (2003) Key competencies: meeting important challenges in life. In: D.S. Rychen and L.H. Salganik (eds), Key Competencies for a Successful Life and Well-functioning Society. Cambridge, MA: Hogrefe and Huber, 63-107.

URL: https://pubengine2.s3.eu-central-1.amazonaws.com/preview/99.110005/9781616762728_preview.pdf

27.Sachs, J.D. (2012) From Millennium Development Goals to Sustainable Development Goals. Lancet, 379:

2206-2211.

28.Schaeffer, S. (2006) Beyond 'learning to live together': The key to education for sustainable development. Presentation at the UNESCO Expert Meeting on ESD: 'Reorienting Education to Address Sustainability', 1-3 May 2006, Kanchanaburi, Thailand.

29.Schulz, W., Ainley, J., Fraillon, J., Kerr, D. and Losito, B. (2010) ICCS 2009 International Report: Civic Knowledge, Attitudes, and Engagement Among Lower-secondary School Students in 38 countries. Amsterdam: International Association for the Evaluation of Educational Achievement. URL:

https://heefa.net/files/ICCS_2009_International_Report.pdf

30.Slavich, G. M. and Zimbardo, P. G. (2012) Transformational Teaching: Theoretical Underpinnings. Basic Principles, and Core Methods. Educational Psychology Review, Vol. 24, No. 4, 569-608.

31.Sleurs, W. (2008) Competencies for ESD (Education for Sustainable Development) teachers. A framework to integrate ESD in the curriculum of teacher training institute. Brussels: CSCT. URL: www.unece.org/fileadmin/DAM/env/esd/inf.meeting.docs/EGonlnd/8mtg/CSCT\%2OHandbook_Extract.pdf (accessed 17 May 2017).

32.Sterling, S. (2016) A commentary on education and Sustainable Development Goals. Journal of Education for Sustainable Development, 10(2): 208-213. URL:

https://www.researchgate.net/publication/308816595_A_Commentary_on_Education_and_Sustainable_Develop ment_Goals

33. The World We Want (2013) Breaking down the Silos: Integrating Environmental Sustainability in the Post-2015 Agenda. URL: http://www.worldwewant2015.org/sustainability

34. UNESCO (1977) Tbilisi Declaration. Intergovernmental Conference on Environmental Education. Tbilisi: UNESCO. URL: http://unesdoc.unesco.org/images/0003/000327/032763eo.pdf

35. UNESCO (2000) The Dakar Framework for Action. Education for All: Meeting our Collective Commitments. The World Education Forum. Dakar: UNESCO, 17. URL: https://sustainabledevelopment.un.org/content/documents/1681Dakar\%20Framework\%20for\%20Action.pdf

36.UNESCO (2005) United Nations Decade of Education for Sustainable Development (2005-2014): International Implementation Scheme. Paris, UNESCO. URL: https://unesdoc.unesco.org/ark:/48223/pf0000148654 
37.UNESCO (2008) EFA-ESD Dialogue: Educating for a sustainable world. Paris, UNESCO. URL: https://unesdoc.unesco.org/ark:/48223/pf0000178044

38.UNESCO (2009) Bonn Declaration. UNESCO World Conference on Education for Sustainable Development. Bonn: UNESCO, pp. 1-31. URL: https://unesdoc.unesco.org/ark:/48223/pf0000188799

39. UNESCO (2009) Learning for a Sustainable World: Review of Contexts and Structures for Education for Sustainable Development.Paris: UNESCO. URL: https://doi.org/10.2139/ssrn.1485401

40.UNESCO (2011) ESD: Education for Sustainable Development - building a better, fairer world for the 21st century. URL: https://unesdoc.unesco.org/ark:/48223/pf0000216673

41.UNESCO (2012) From Green Economies to Green Societies:. UNESCO's Commitment to Sustainable Development. URL:

https://www.greengrowthknowledge.org/sites/default/files/downloads/resource/Green_Economy_UNESCO.pdf

42.UNESCO (2013) Concept note on the post-2015 education agenda. URL:

http://www.unesco.org/new/fileadmin/MULTIMEDIA/HQ/ED/ED_new/pdf/UNESCOConceptNotePost2015_ENG.pd $f$

43.UNESCO (2013) Global Citizenship Education: An Emerging Perspective. URL:

http://unesdoc.unesco.org/images/0022/002241/224115E.pdf

44.UNESCO (2014) Shaping the Future We Want: UN Decade for Sustainable Development (2005-2014)

Final Report. Paris: UNESCO. URL: http://unesdoc. unesco.org/images/0023/002301/230171e.pdf (accessed 28 January 2017)

45.UNESCO (2014) Global Citizenship Education: Preparing learners for the challenges of the 21stcentury. Paris: UNESCO. URL:

http://www.eunec.eu/sites/www.eunec.eu/files/attachment/files/global_citizenship_education_report..pdf

46. UNESCO (2014) Teaching and Learning: Achieving Quality for All. EFA Global Monitoring Report 2013-

2014. Paris: UNESCO. URL: https://unesdoc.unesco.org/ark:/48223/pf0000225660

47.UNESCO (2014) Aichi-Nagoya Declaration on Education for Sustainable Development. Okayama, Japan:

UNESCO.

URL: https://sustainabledevelopment.un.org/content/documents/5859Aichi-Nagoya_Declaration_EN.pdf

48.UNESCO (2014) UNESCO Roadmap for Implementing the Global Action Programme on Education for

Sustainable Development. Paris: UNESCO. URL: https://unesdoc.unesco.org/ark:/48223/pf0000230514

49. UNESCO (2015) Rethinking Education. Towards a Global Common Good? Paris: UNESCO. URL:

http://unesdoc.unesco.org/images/0023/002325/232555e.pdf (accessed 17 May 2017).

50.UNESCO (2015) Framework for Action Education 2030: Towards Inclusive and Equitable Quality Education and Lifelong Learning for All(draft). Incheon: UNESCO.

51.UNESCO (2016) Education 2030. Incheon Declaration and Framework for Action. Towards Inclusive and Equitable Quality Education and Lifelong Learning for All. Paris: UNESCO. URL:

www.uis.unesco.org/Education/Documents/incheon-framework-for-action-en .pdf (accessed 17 May 2017).

52.UNESCO (2016) Global Education Monitoring Report - Education for People and Planet: Creating Sustainable Futures for All. Paris: UNESCO. URL: https://unesdoc.unesco.org/ark:/48223/pf0000245752

53.UNESCO (2017) Education for Sustainable Development Goals. Learning Objectives. Paris: UNESCO. URL: http://unesdoc.unesco.org/images/0024/002474/247444e.pdf (accessed 17 May 2017).

54.UNECE (United Nations Economic Commission for Europe) (2005) UNECE Strategy for Education for Sustainable Development. Geneva: UNECE. URL: www.unece.org/fileadmin/DAM/env/documents/2005/ cep.ac.13.2005.3.rev.1.e.pdf (accessed: 17 May 2017).

55.UNECE (2011) Learning for the future: Competences in Education for Sustainable Development. URL: http://www.unece.org/fileadmin/DAM/env/esd/6thMeetSC/Learning\%20for\%20the\%20Future_\%20Competences \%20for\%20Educators\%20in\%20ESD/ECE_CEP_AC13_2011_6\%20COMPETENCES\%20EN.pdf

56.UNECE (2012) Learning for the Future: Competences in Education for Sustainable Development. Geneva: UNECE. URL: www.unece.org/fileadmin/DAM/env/esd/ESD_Publications/Competences_Publication.pdf (accessed: 17 May 2017).

57. United Nations World Summit (2005) 2005 World Summit Outcome. URL: www.un.org/en/ga/search/view_doc.asp?symbol=A/RES/60/1 
58. United Nations General Assembly (2013) Progress report of the Open Working Group of the General Assembly on Sustainable Development Goals. URL:

http://www.un.org/ga/search/view_doc.asp?symbol=A/67/941\&Lang=E

59. United Nations (2015) 2030 Agenda for Sustainable Development and its 17 Sustainable Development

Goals. URL: www.un.org/sustainabledevelopment

60. United Nations (2015) The Millennium Development Goals Report, 2015. New York: United Nations.

URL:

https://www.un.org/millenniumgoals/2015_MDG_Report/pdf/MDG\%202015\%20rev\%20(July\%201).pdf

61.Vare, P. and Scott, W. (2007) Learning for a change: exploring the relationship between education and sustainable development. Journal of Education for Sustainable Development, 1(2): 191-198. URL:

https://www.researchgate.net/publication/258157776_Learning_for_a_Change

62.Wals, A.E.J. (2015) Beyond Unreasonable Doubt. Education and Learning for Socio-ecological Sustainability in the Anthropocene. Wageningen, Netherlands: Wageningen University. URL:

https://arjenwals.files.wordpress.com/2016/02/8412100972_rvb_inauguratie-wals_oratieboekje_v02.pdf (accessed 17 May 2017);

63.Wals, A.E.J. and Lenglet, F. (2016) Sustainability citizens: Collaborative and disruptive social learning. R. Horne, J. Fien, B. Beza and A. Nelson (eds), Sustainability Citizenship in Cities: Theory and Practice. London:

Routledge. URL: https://www.routledge.com/Sustainability-Citizenship-in-Cities-Theory-and-practice/Horne-FienBeza-Nelson/p/book/9781138933637

64.Wiek, A., Withycombe, L. and Redman, C.L. (2011) Key competencies in sustainability: a reference framework for academic program development. Sustainability Science, 6(2), 203-218. URL:

https://link.springer.com/article/10.1007/s11625-011-0132-6

65.Wiek, A., Bernstein, M.J., Foley, R.W., Cohen, M., Forrest, N., Kuzdas, C., Kay, B. and Withycombe Keeler, L. (2016) Operationalising competencies in higher education for sustainable development. In: M. Barth, G. Michelsen, I. Thomas and M. Rieckmann (eds), Routledge Handbook of Higher Education for Sustainable Development. London: Routledge, 241-260. URL:

84 https://www.academia.edu/627055/Key_competencies_in_sustainability_a_reference_framework_for_academic_ program_development 


\title{
Розділ IV. Стратегії вищої освіти в умовах інтернаціоналізації для стійкого розвитку: проблема якості
}

\author{
Сергій Курбатов, \\ доктор філософських наук, \\ головний науковий співробітник \\ відділу інтернаціоналізації вищої освіти \\ Інституту вищої освіти НАПН України \\ https://orcid.org/0000-0002-8929-7562
}

Анотація. Даний розділ присвячено методичним рекомендаціям, які стосуються розробки стратегій інтернаціоналізації закладів вищої освіти, спираючись на підходи, сформовані у англомовній академічній літературі, а також досвід українських та зарубіжних університетів. Передбачено, що подібна стратегія має три рівні: 1) глобальний, який тлумачиться у контексті парадигми сталого розвитку із акцентом на Резолюцію Організації Об'єднаних Націй «Перетворення нашого світу: порядок денний в області сталого розвитку на період до 2030 року» та мережеву ініціативу The United Nations Academic Impact (UNAI); 2) регіональний або національний, який, в українському контексті, визначають підходи та практики Європейського простору вищої освіти та Європейського дослідницького простору ma 3) інституційний, обумовлений специфікою діяльності конкретного закладу вищої освіти та його місією. Відповідні положення проілюстровані підходами, які покладено в основу прийнятої у 2019 році стратегії інтернаціоналізації Сумського державного університету - одного із інституційних лідерів вітчизняної системи вищої освіти. Зроблено акцент на ролі провідних міжнародних університетських рейтингів - Academic Ranking of World Universities (ARWU) або Шанхайському рейтингу, QS World University Rankings або рейтингу QS та THE World University Rankings або рейтингу Таймс - у процесах інтернаціоналізації вищої освіти та забезпечення її якості. Також розглянуто процес входження закладів вищої освіти до баз даних цих рейтингів. 


\section{Якісні виміри стратегії інтернаціоналізації закладу вищої освіти}

Впродовж останнього десятиліття інтернаціоналізація стала одним із основних напрямків діяльності закладів вищої освіти в Україні. Можна констатувати успішне подолання сформованої ще за радянських часів практики штучного обмеження розвитку міжнародних зв'язків, ставлення із підозрою до тих, хто до них активно залучений, ігнорування необхідності адекватного регулювання нормативно-правових та фінансових питань у галузі міжнародного академічного співробітництва. Потужний імпульс розвитку процесів інтернаціоналізації університетського середовища надали процеси інтеграції України та її системи освіти до європейських структур, які активно відбуваються починаючи із 2014 року. Оскільки питання забезпечення якості вищої освіти є пріоритетними в процесі формування Європейського простору вищої освіти, вони органічно пов'язані із процесами інтернаціоналізації та $€$ їх важливим складовим компонентом. Саме тому питання якості при формуванні стратегій інтернаціоналізації у наш час стає особливо актуальним та потребує детального розгляду.

Тут, по-перще, може йти мова про якість стратегій інтернаціоналізації закладів вищої освіти та інших академічних установ - звичайно, як складової частини загальної стратегії розвитку відповідної інституції. Так, у стратегії інтернаціоналізації одного із інституційних лідерів вітчизняного простору вищої освіти, Сумського державного університету, яка почала діяти 26 березня 2019 року, зазначається: «Стратегію розроблено відповідно до Стратегічного плану розвитку СумДУ на 2019-2025 роки, в якому широкомасштабна міжнародна спрямованість визначена, серед іншого, головною домінантою розвитку університету та має відображення в усіх його розділах. Разом з цим, стратегія узагальнює основні напрямки міжнародної діяльності та, у свою чергу, розширює і деталізує кожен з них» ${ }^{1}$. Тобто якісна стратегія інтернаціоналізації $\epsilon$ органічною складовою та принципом функціонування університету, яка має трансверсальний характер та орієнтацію на регіональний та глобальний контексти. Нижче ми спробуємо сформулювати основні принципи розробки відповідної стратегії.

По-друге, стратегія інтернаціоналізації вищої освіти повинна ефективно працювати на процеси забезпечення якості вищої освіти та ії перманентного покращення. I тут варто зосередити увагу на провідних міжнародних університетських рейтингах як неформальних, та, мабуть, найбільш популярних та найбільш доступних для широкого загалу сучасних механізмах забезпечення якості вищої освіти. Саме міжнародні університетські рейтинги впродовж останнього десятиліття «постійно посилюють свою роль у статусній конкуренції як між університетами, так і між урядами різних країн» - зазначають у нещодавно надрукованій статті Tero Erkkilä та Ossi Piironen². Детальному розгляду процесу входження закладів вищої освіти до баз даних провідних університетських рейтингів, а також аналіз властивих даним рейтингам індикаторів інтернаціоналізації буде присвячено наступний підрозділ цих методичних матеріалів.

Як розробити якісну стратегію інтернаціоналізації вітчизняного закладу вищої освіти? Звичайно, перш за все, треба добре розуміти теоретичне підґрунтя процесів інтернаціоналізації вищої освіти, перш за все в європейському та глобальному контекстах. I тут колегам стане у нагоді надруковане у 2019 році дисертаційне дослідження на здобуття наукового ступеня доктора педагогічних наук співробітниці Інституту вищої освіти НАПН України Марії Дебич «Теоретичні засади інтернаціоналізації вищої освіти: міжнародний досвід» Особливу увагу варто звернути на четвертий розділ дослідження, присвячений розгляду стратегій інтернаціоналізації та їх основних складових в університетах світу ${ }^{4}$. «Сучасний стан інтернаціоналізації вітчизняної вищої освіти засвідчує актуальність створення науково обґрунтованої концепції інтернаціоналізації вищої освіти України, яка має на меті окреслити параметри ефективної моделі розвитку інтернаціоналізації вищої освіти та створення ії позитивного міжнародного іміджу, а також визначити перехід від нинішнього стану інтернаціоналізації до такого, що відповідає принципам і пріоритетам Європейського простору вищої освіти, Європейського дослідницького простору, світовим тенденціям з урахуванням при цьому національних традицій та особливостей» - зазначає вона у висновках 5 .

\footnotetext{
${ }^{1}$ Стратегія інтернаціоналізації Сумського державного університету на 2019-2025 роки. Суми, 2019. - С. 2.

2 Erkkilä, Tero \& Ossi Piironen Trapped in university rankings: bridging global competitiveness and local innovation. International Studies in Sociology of Education. 2019. P. 1. DOI: 10.1080/09620214.2019.1634483

${ }^{3}$ Дебич М. Теоретичні засади інтернаціоналізації вищої освіти: міжнародний досвід: монографія. Ніжин: ПП Лисенко. 2019. 408 c.

${ }^{4}$ Tам само. С. 201-184.
${ }^{5}$ Tам само. C. $327-328$.
} 
Серед англомовних наукових розвідок, результати яких було надруковано у 2019 році, хотілося 6 звернути увагу на статтю Kumari Beck та Roumiana llieva «"Doing" internationalization: principles to practice» ${ }^{6}$. «Ми розглянули проблему, з якою нам приходиться постійно боротися під час інтернаціоналізації університету як викладачам, дослідникам, менторам - а саме із роллю досліджень для визначення принципових практик інтернаціоналізації. Для цього ми розглянули найбільш поширені ідеології , орієнтації та артикуляції інтернаціоналізації» - зазначають автори․ Цікавий матеріал щодо теоретичних підходів до розробки стратегій інтернаціоналізації у сучасних умовах містить і стаття Hantian Wu «Three dimensions of China's "outward-oriented" higher education internationalization»". Отже, проблема розробки якісної стратегії інтернаціоналізації сучасного університету та її теоретичне осмислення продовжує знаходитись у фокусі уваги сучасних дослідників.

Переходячи до наступних методичних рекомендацій щодо розробки якісної стратегії інтернаціоналізації сучасного українського закладу вищої освіти, варто розпочати з ї̈ першого, глобального рівня, який втілює єдність сучасної цивілізації та базується на загальнолюдських цінностях. Провідними світовими інституціями, які забезпечують функціонування цього рівня, $є$ Організація Об'єднаних Націй $(\mathrm{OOH})^{9}$, яка об'єднує представників 193 країн, та її спеціалізовану установу, Організацію Об'єднаних Націй з питань освіти, науки і культури (ЮНЕСКО) ${ }^{10}$. Ключовим міжнародним документом, який регулює освітні питання на цьому рівні, є прийнята 25 вересня 2015 року Резолюція Організації Об'єднаних Націй «Перетворення нашого світу: порядок денний в області сталого розвитку на період до 2030 року ${ }^{11}$. Я аналізував вплив цього документу на практики інтернаціоналізації вищої освіти у минулорічному випуску аналітичних матеріалів ${ }^{12}$. Безперечно, стратегія інтернаціоналізації сучасного українського закладу вищої освіти повинна відповідати вимогам цього документу, та, зокрема, робити акцент на четверту ціль, яка передбачає «забезпечення всеохоплюючої і справедливої якісної освіти та заохочення можливості навчання впродовж усього життя для всіх» ${ }^{13}$, а також вимагає «до 2030 року забезпечити для всіх чоловіків та жінок рівний доступ до недорогої та якісної професійної та вищої, в тому числі, університетської, освіти» ${ }^{14}$.

Серед ініціатив ООН останнього десятиліття, орієнтованих на досягнення цілей сталого розвитку в галузі вищої освіти та забезпечення ії якості, слід відзначити започатковану у 2010 році глобальну мережеву ініціативу The United Nations Academic Impact (UNAI) ${ }^{15}$, до якої на даний момент залучені більше 1300 закладів вищої освіти із більш ніж 130 країн, у тому числі 28 закладів вищої освіти України ${ }^{16}$. В основу діяльності цієї ініціативи покладена підтримка та просування 10 принципів: 1) сприяння подоланню бідності за допомогою освіти; 2) розвиток та зміцнення потенціалу громади в усіх системах вищої освіти; 3) сприяння доступу до освіти усім людям; 4) сприяння реалізації концепції глобального громадянства із допомогою освіти; 5) сприяння створенню умов для отримання кожною зацікавленою особою знань та вмінь, необхідних для отримання вищої освіти; 6) зобов'язання дотримуватись прав людини, зокрема, свободи пізнання, свободи слова та свободи власної думки; 7) зобов'язання сприяти міжкультурному діалогу, взаєморозумінню та вихованню толерантності із допомогою освіти; 8) обов'язково сприяти зміцненню миру та врегулюванню конфліктів із допомогою освіти; 9) зобов'язання сприяти сталому розвитку за допомогою освіти; 10) відповідність цілям та принципам, закладеним в Уставі ООН ${ }^{17}$. Участь у діяльності цієї ініціативи ООН в галузі вищої освіти для досягнення цілей сталого розвитку, є безкоштовною, а задля приєднання до неї необхідно

${ }^{6}$ Beck, Kumari \& Roumiana llieva "Doing" internationalization: principles to practice. Simon Fraser University Educational Review. 2019. Vol. 11. \# 3. P. 18-39.

${ }^{7}$ Beck, Kumari \& Roumiana llieva. Ibid. P. 35.

${ }^{8}$ Hantian Wu Three dimensions of China's "outward-oriented" higher education internationalization. Higher Education.2019. Vol. 77. \# 1. P. 81-96.

${ }^{9}$ United Nations. URL: https://www.un.org/en/

${ }^{10}$ UNESCO. URL: https://en.unesco.org/

11 Преобразование нашего мира: повестка дня в области устойчивого развития на период до 2030 года. URL: https://undocs.org/ru/A/RES/70/1

12 Курбатов С. Стратегії вищої освіти в умовах інтернаціоналізації: проблема якості. URL: https://ihed.org.ua/wpcontent/uploads/2019/08/Analiz_strategiy_VO_v_umovah_internac_ch1_analit_IVO-2018-113p_avtors-kolektiv.pdf

${ }^{13}$ Преобразование нашего мира: повестка дня в области устойчивого развития на период до 2030 года. URL: https://undocs.org/ru/A/RES/70/1

${ }^{14}$ Там само.

${ }^{15}$ The United Nations Academic Impact. URL: https://academicimpact.un.org/

${ }^{16}$ UNAI Member List. URL:

https://academicimpact.un.org/sites/academicimpact.un.org/files/UNAI\%20MEMBERS\%20LIST\%20FEBRUARY\%202020.pdf

${ }^{17}$ UNAI Principles. URL: https://academicimpact.un.org/content/principles 
заповнити онлайн-форму ${ }^{18}$. Зміст ініціативи та ї̈ вплив на інтернаціоналізацію конкретного університету детально описані у статті Angel Oi Yee Cheng "Global Mission - "Glocal" Internationalization: United Nations Academic Impact (UNAI) and Lehigh University»" ${ }^{19}$, яку надруковано у 2019 році. Зокрема, у цій статті зазначається, що вплив UNAI на інституційне життя університету можна розглядати у наступних ракурсах: 1) інтернаціоналізація університету; 2) інтернаціоналізація вдома; 3) інтернаціоналізація за кордоном; 4) зв'язки із ОOH та INAI та 5) пост-колоніальна спадщина ${ }^{20}$.

Переходячи до регіонального та національного рівня інтернаціоналізації вищої освіти у контексті забезпечення якості, слід відзначити, що для України, починаючи із 2014 року, цей процес пов'язаний із імплементацією європейських підходів та практик, а також розбудову відповідальних зв це інституцій. Відповідні положення знайшли відображення у прийнятому Верховною Радою України 1 липня 2014 року Законі України «Про вищу освіти», п'ятий розділ якого присвячений питанням забезпечення якості ${ }^{21}$. Зокрема, тут зафіксовані та законодавчо врегульовані питання функціонування внутрішньої та зовнішньої систем забезпечення якості вищої освіти, а також визначені принципи формування ключової інституції системи забезпечення якості вищої освіти - Національного агентства із забезпечення якості вищої освіти ${ }^{22}$ П'ятий розділ прийнятого 5 вересня 2017 року Закону України «Про освіту» ${ }^{23}$ також присвячено питанням якості. Важливою правовою інновацією цього розділу стало введення у законодавче поле поняття академічної доброчесності та принципів ї̈ дотримання та забезпечення.

Головним загальноєвропейським документом, який регламентує питання забезпечення якості в процесі інтернаціоналізації вищої освіти та на який, значною мірою, зорієнтоване сучасне українське законодавство у даній сфері, $€$ «Стандарти і рекомендації щодо забезпечення якості в Європейському просторі вищої освіти ESG» остання, суттєво виправлена та доповнена версія яких була прийнята Міністерською конференцією в Єревані 14-15 травня 2015 року ${ }^{24}$. Як я вже зазначав: «Ключові положення ESG 2015 містяться у розділі, присвяченому Європейським стандартам та рекомендаціям щодо забезпечення якості у вищій освіті. Цей розділ включає уніфіковані вимоги щодо внутрішнього забезпечення якості, зовнішнього забезпечення якості та діяльності агентств із забезпечення якості» ${ }^{25}$. Характеризуючи цей рівень, розробники стратегії інтернаціоналізації Сумського державного університету підкреслюють: «Головним вектором розвитку України та ї̈ національної системи вищої освіти $\epsilon$ європейська інтеграція. Ключовим етапом даного процесу стало входження України до Європейського простору вищої освіти (ЄПВО) з моменту його створення у 2010 році, чому передувало підписання Лісабонської Конвенції з визнання кваліфікацій вищої освіти у 2000 році та приєднання до Болонського процесу у 2005 році. Розбудова систем забезпечення якості вищої освіти у відповідності до Європейських стандартів і рекомендацій була закріплена законодавчо у 2014 році... Саме Європейським Союзом запроваджуються найбільш масштабні інструменти фінансової та організаційної підтримки модернізації вищої освіти і науки, зокрема через міжнародні програми Еразмус+ та Горизонт 2020» ${ }^{26}$.

На інституційному рівні для розробки ефективної стратегії інтернаціоналізації закладам вищої освіти варто провести детальний аналіз існуючих підходів та практик цього процесу із особливим акцентом на питання забезпечення якості. Для цього можна використати досить просту та популярну методику SWOTаналізу ${ }^{27}$, яка дозволить виявити сильні та слабкі сторони процесів інтернаціоналізації на рівні конкретного закладу вищої освіти, існуючі можливості для їх розвитку, та загрози, які при цьому виникають. Отримані результати варто детально обговорити із внутрішніми та зовнішніми експертами у галузі інтернаціоналізації. В якості внутрішніх експертів можна розглядати осіб, які вже залучені або ж планують бути залученими до процесів інтернаціоналізації. Саме ці особи повинні бути максимально залученими до розробки відповідної

${ }^{18}$ UNAI Enrollment Form. URL: https://academicimpact.un.org/content/enrollment-form

${ }^{19}$ Angel Oi Yee Cheng Global Mission - "Glocal” Internationalization: United Nations Academic Impact (UNAI) and Lehigh University. Journal of Comparative and International Higher Education. 2019. \# 11. P. 41-51.

${ }^{20}$ Angel Oi Yee Cheng Ibid. P. 45.

${ }^{21}$ Закон України Про вищу освіту. URL: https://zakon.rada.gov.ua/laws/show/1556-18

${ }^{22}$ Національне агентство із забезпечення якості вищої освіти. URL: https://naqa.gov.ua/

23 Закон України Про освіту. URL: https://zakon.rada.gov.ua/laws/show/2145-19

${ }^{24}$ Стандарти і рекомендації щодо забезпечення якості в Європейському просторі вищої освіти ESG. URL: http://www.britishcouncil.org.ua/sites/default/files/standards-and-guidelines_for_qa_in the_ehea_2015.pdf

${ }^{25}$ Курбатов С. Стратегії вищої освіти в умовах інтернаціоналізації: проблема якості. URL: https://ihed.org.ua/wpcontent/uploads/2019/08/Analiz_strategiy_VO_v_umovah_internac_ch1_analit_IVO-2018-113p_avtors-kolektiv.pdf

${ }^{26}$ Стратегія інтернаціоналізації Сумського державного університету на 2019-2025 роки. Суми, 2019. - С. 5-6.

${ }^{27}$ SWOT analysis. URL: https://en.wikipedia.org/wiki/SWOT analysis 
стратегії. Як наслідок, ми маємо своєрідний звіт самооцінки стану інтернаціоналізації у контексті забезпечення якості вищої освіти на рівні її конкретного закладу, скорочена версія якого може стати частиною майбутньої стратегії. Так, стратегія інтернаціоналізації Сумського державного університету містить розділ «Досягнутий рівень міжнародної діяльності: структура управління та основні показники» ${ }^{28}$.

Оскільки метою стратегії $€$ активізація процесів інтернаціоналізації та підвищення ії ефективності (у тому числі, у питаннях забезпечення якості вищої освіти), ії головний акцент має бути зосередженим на постановці конкретних завдань, які складаються із певних заходів, результативність яких можна оцінити, спираючись на розроблені для цього індикатори. Так, ключовим складовим елементом стратегії інтернаціоналізації Сумського державного університету $\epsilon$ тріада: 1) постановка стратегічного завдання (наприклад, інтенсивна підтримка міжнародних обмінів співробітниками і студентами); 2) ідентифікація критеріїв їх досягнення та 3) планування конкретних заходів для реалізації стратегічного завдання з метою відповідності означеним критеріям ${ }^{29}$.

Також, розробляючи стратегію інтернаціоналізації вітчизняного закладу вищої освіти, я би порадив колегам звернути увагу на такі важливі індикатори інтернаціоналізації, як відсоток іноземних студентів та викладачів. Показники цих індикаторів є визначальними для оцінки рівня інтернаціоналізації у двох провідних міжнародних університетських рейтингах - QS World University Rankings або рейтингу QS ${ }^{30}$ та THE World University Rankings або рейтингу Таймс ${ }^{31}$. До того ж, залучення до навчання іноземних студентів може стати важливим фінансовим джерелом існування закладу вищої освіти, особливо в умовах можливого скорочення обсягів бюджетного фінансування. За даними Українського державного центру міжнародної освіти Міністерства освіти і науки України, впродовж 2015-2018 років кількість іноземних студентів в Україні збільшилась із 63906 до 75605 осіб, а у 2018-2019 навчальному році 24,67 \% цих студентів походило із пострадянських країн (Азербайджан, Туркменістан, Грузія та інші), а 75,33\% - із інших країн (Індія, Марокко, Нігерія, Єгипет, Туреччина, Китай та інші) $)^{32}$. Найбільшу кількість іноземних студентів в Україні мають Харківський національний медичний університет (4432 осіб), Харківський національний університет імені В.Н. Каразіна (4363 осіб), Одеський національний медичний університет (3780 осіб), Національний медичний університет імені О. О. Богомольця (2601 осіб) та Запорізький державний медичний університет $(2665 \text { осіб) })^{33}$. Як бачимо, найбільшою популярністю серед іноземних студентів користуються українські заклади вищої освіти медичного профілю. Для отримання офіційного запрошення на навчання в Україні, заклад вищої освіти повинен звернутися до Українського державного центру міжнародної освіти Міністерства освіти і науки України, заповнивши заявку за посиланням ${ }^{34}$

\footnotetext{
${ }^{28}$ Стратегія інтернаціоналізації Сумського державного університету на 2019-2025 роки. Суми, 2019. - С. 11-14.

${ }^{29}$ Там само.

${ }^{30}$ QS World University Rankings. URL: https://www.topuniversities.com/qs-world-university-rankings

${ }^{31}$ THE World University Rankings. URL: https://www.timeshighereducation.com/world-university-rankings

32 Іноземні студенти в Україні. URL: https://studyinukraine.gov.ua/zhittya-v-ukraini/inozemni-studenti-v-ukraini/

${ }^{33}$ Там само.

${ }^{34}$ Запрошення на навчання. URL: https://studyinukraine.gov.ua/yak-podati-zayavku/priglashenie-na-obuchenie/
} 


\section{Входження закладів вищої освіти до баз даних провідних міжнародних університетських рейтингів}

Як ми вже наголошувати ${ }^{35}$, входження провідних вітчизняних закладів вищої освіти $є$ важливим та необхідним складовим елементом ефективної стратегії інтернаціоналізації у контексті забезпечення якості вищої освіти. Більшість міжнародних університетських рейтингів спираються на чіткі, прозорі та зрозумілі індикатори оцінки діяльності університетів, і, тим самим, дають адекватне розуміння їх місця у системі вищої освіти країни, регіону, чи світу взагалі. Рейтинги активно використовуються урядовими структурами для ідентифікації провідних університетів та організації програм їх підтримки та розвитку. Так, розроблена Міністерством освіти і науки України у 2019 році формула розподілу фінансування закладів вищої освіти включає оцінку їх позиції у міжнародних рейтингах. Детально із цією формулою можна ознайомитись у тексті Постанови Кабінету Міністрів України № 1146 «Про розподіл видатків державного бюджету між закладами вищої освіти на основі показників їх освітньої, наукової та міжнародної діяльності» від 24 грудня 2019 року ${ }^{36}$. Міжнародні університетські рейтинги також можна розглядати як альтернативний механізм оцінки та забезпечення якості вищої освіти, який дуже динамічно відображає інтереси головних стейкхолдерів вищої освіти та їх очікування від університетської діяльності ${ }^{37}$. Далі ми спробуємо детально розглянути існуючи алгоритми створення необхідних передумов для входження провідних вітчизняних закладів вищої освіти до трьох найбільш впливових та авторитетних міжнародних університетських рейтингів: Academic Ranking of World Universities (ARWU) або Шанхайського рейтингу ${ }^{38}$, QS World University Rankings або рейтингу QS ${ }^{39}$ та THE World University Rankings або рейтингу Таймс ${ }^{40}$. Необхідною передумовою входження до міжнародних університетських є поява університету у базі даних відповідного рейтингу. Зазначимо при цьому, що для успіху процесу важлива активна та професійна комунікація конкретного представника українського закладу вищої освіти із укладачами відповідного міжнародного рейтингу.

Розпочнемо розгляд із першого міжнародного університетського рейтингу ARWU або Шанхайського рейтингу, який «використовує лише об’єктивні індикатори, які оцінюють, переважно, науково-дослідницьку діяльність університету у глобальному контексті - тобто сприяє інтернаціоналізації саме на цьому рівні. Шанхайський рейтинг часто ще називають рейтингом лауреатів Нобелевської премії, адже відповідна категорія науковців серед випускників та співробітників, разом з лауреатами медалі Філдса - найвищої нагороди математиків, складає 30\% «ваги» цього рейтингу»" ${ }^{41}$. Формуванням та розширенням бази даних університетів в рамках цього рейтингу займається проект Global Research University Profiles (GRUP), який було започатковано у січні 2011 року. Починаючи із 2016 року, опитуванням закладів вищої освіти, яке здійснюється в рамках GRUP, займається ShanghaiRanking Consultancy ${ }^{42}$. Метою опитування GRUP $€$ отримання такої базової інформації про заклад вищої освіти, як: кількість академічних співробітників, кількість студентів, загальний прибуток, прибуток від дослідницької діяльності та інші дані ${ }^{43}$. Отримані дані згодом викладаються на онлайновій платформі, яка дозволяє порівнювати дослідницькі університети за 35 індикаторами, що оцінюють студентів, співробітників та матеріальну базу університету ${ }^{44}$. Наразі у відкритому доступі ця база даних містить інформацію за 2018 рік. Інформація про університети збирається щорічно, у період із квітня по липень за передостанній календарний або попередній академічний рік - наприклад, впродовж квітня-липня 2019 року співробітники проекту збирали інформацію за 2017 календарний або 20172018 академічний рік ${ }^{45}$.

\footnotetext{
${ }^{35}$ Курбатов, С. Стратегії вищої освіти в умовах інтернаціоналізації: проблема якості. - URL: https://ihed.org.ua/wpcontent/uploads/2019/08/Analiz strategiy VO v umovah internac ch1 analit IVO-2018-113p avtors-kolektiv.pdf

${ }^{36}$ Постанова Кабінету Міністрів України № 1146 «Про розподіл видатків державного бюджету між закладами вищої освіти на основі показників їх освітньої, наукової та міжнародної діяльності» від 24 грудня 2019 року. URL: https://zakon.rada.gov.ua/laws/show/1146-2019-\%D0\%BF

${ }^{37}$ Курбатов, С. Університетські рейтинги як альтернативний механізм освітніх вимірювань/ Сергій Курбатов. Рідна школа. 2017.- № 1-2. - С. 3-6.

${ }^{38}$ Academic Ranking of World Universities. - URL: http://www.shanghairanking.com/index.html

${ }^{39}$ QS World University Rankings. - URL: https://www.topuniversities.com/qs-world-university-rankings

${ }^{40}$ THE World University Rankings. - URL: https://www.timeshighereducation.com/world-university-rankings

${ }^{41}$ Курбатов, С. Рейтингові системи як «флюорографія». - С. 3. - URL: http://essuir.sumdu.edu.ua/handle/123456789/70815

${ }^{42}$ About Global Research University Profiles. - URL: http://www.shanghairanking.com/grup/survey/about-GRUP-Survey.html

${ }^{43}$ Ibid.

${ }^{44}$ Global Research University Profiles. - URL: http://www.shanghairanking.com/grup/index.html

${ }^{45}$ GRUP Survey FAQs. - URL: http://www.shanghairanking.com/grup/survey/2019/GRUP Survey FAQs 2019.pdf
} 
Для того, щоб приєднатися до проекту GRUP, закладам вищої освіти пропонується зробити три кроки: 1) ввести загальну інформацію про заклад вищої освіти; 2) ввести інформацію про навчальну та дослідницьку діяльність у закладі вищої освіти та 3) перевірити інформацію та завантажити її на сайт проекту ${ }^{46}$. Для того, щоб отримати доступ для анкети GRUP, заклад вищої освіти повинен визначити відповідальну особу, якій будуть надіслані відповідні логін та пароль. Ініціювати відповідну комунікацію можна, написавши листа на адресу: grup@shanghairanking.com ${ }^{47}$. Детальну інформацію щодо заповнення анкети у 2019 році містить GRUP Survey Guide ${ }^{48}$. Зміст опитувальника, якій використовувався у 2019 році, містить GRUP Survey Questionnaire ${ }^{49}$. Загальна інформація про заклади вищої освіти містить наступні питання: назва англійською та рідною мовою; абревіатура англійською мовою; рік заснування; поштова адреса; номер телефону та адреса електронної пошти; адресу веб-сторінки; короткий опис закладу вищої освіти (не більше тисячі слів), а також інформацію про контактну особу, відповідальну за комунікацію із проектом ${ }^{50}$. Інформація про навчальну та дослідницьку діяльність у закладі вищої освіти містить наступні питання: кількість педагогічних співробітників, які зайняті лише викладацькою діяльністю; кількість наукових співробітників, які зайняті лише дослідницькою діяльністю; кількість студентів, які отримують ступінь бакалавра; кількість студентів, які отримують ступінь магістра; кількість студентів, які отримують докторський ступінь; кількість присуджених докторських ступенів; рівень безробіття серед випускників на всіх ступенях; інституційний прибуток, який надходить: від органів державної влади та місцевого самоврядування, від оплати за навчання та інших послуг, від благодійників, від власних інвестицій та бізнесу; прибуток від дослідницької діяльності, який надходить від органів державної влади та місцевого самоврядування та від співпраці із промисловістю та інші ${ }^{51}$.

На відміну від Шанхайського рейтингу, який розраховується виключно на основі об'єктивних даних, в рейтингу QS 50\% «ваги» складають дані суб'єктивні, які отримані в результаті опитування - експертів в галузі вашої освіти (40\%) та роботодавців (10\%), а рівень інтернаціоналізації університету оцінюється у відповідності із відсотком іноземних студентів та викладачів ${ }^{52}$. Детальну інформацію щодо входження до QS World University Rankings або рейтингу QS можна знайти у матеріалі Sarah Linney How to Enter QS World University Rankings, розміщеному на офіційному сайті цього рейтингу ${ }^{53}$. Як і в Шанхайському рейтингу, роботу треба починати з призначення особи, відповідальної за взаємодії із укладачами рейтингу. Для цього слід заповнити спеціальну онлайн-форму. Після цього рекомендується провести пояснювальну роботу щодо переваг, які надає закладу вищої освіти входження у рейтинг, а також сформувати широку команду підтримки цього процесу. Потрібно сприяти якнайбільш ширшому розумінню основних індикаторів рейтингу та можливих шляхів покращення відповідних показників серед співробітників університету. Важливим також $\epsilon$ оперативність співробітників у донесенні нових даних до співробітників рейтингової агенції та чітке дотримання існуючих дедлайнів ${ }^{54}$. Детальну інформацію про рейтинги взагалі, та QS World University Rankings зокрема, можна знайти в електронній брошурі Demystifying the Rankings: A Guide for Universities ${ }^{55}$. Вона включає наступні розділи: 1) що таке університетські рейтинги; 2) загальний огляд рейтингу QS; 3) роль рейтингів в інституційному розвитку (в тому числі, чому корисні дані, які збирають рейтинги та як можна використовувати рейтинги для стратегічного розвитку); 4) що думають про рейтинги студенти та 5) майбутнє рейтингів ${ }^{56}$.

У порівнянні із іншими провідними міжнародними університетськими рейтингами, укладачі рейтингу QS на платній основі надають послугу своєрідного аудиту діяльності закладів вищої освіти, яка має назву QS Stars University Ratings ${ }^{57}$. У рамках цього проекту оцінюються дванадцять напрямків університетської діяльності: 1) дослідження; 2) викладання; 3) академічний розвиток; 4) працевлаштування випускників; 5)

${ }^{46}$ GRUP Survey. URL: http://www.shanghairanking.com/grup/survey/index.html

${ }^{47}$ Support of GRUP Survey. URL: http://www.shanghairanking.com/grup/survey/support-of-GRUP-Survey.html

${ }^{48}$ GRUP Survey Guide - 2019. URL: http://www.shanghairanking.com/grup/survey/2019/GRUP Survey Guide 2019.pdf

${ }^{49}$ GRUP Survey Questionnnaire - 2019. URL:

http://www.shanghairanking.com/grup/survey/2019/GRUP_Survey Definition_2019.pdf

${ }^{50}$ Ibid.

51 Ibid.

${ }^{52}$ QS Methodology. URL: https://www.topuniversities.com/qs-world-university-rankings/methodology

${ }^{53}$ Linney, Sarah How to Enter QS World University Rankings. URL: https://www.qs.com/how-enter-qs-world-university-rankings/

${ }^{54}$ Ibid.

${ }^{55}$ Demystifying the Rankings: A Guide for Universities. - URL: https://www.qs.com/portfolio-items/demystifying-the-rankings-aguide-for-universities/?utm_source=qswebsite\&utm_medium=blog

${ }^{56}$ West, Josie, George Mattis \& Georgia Philippou Demystifying the Rankings: A Guide for Universities. QS, 2019. - 15 p.

${ }^{57}$ QS Stars University Ratings. URL: https://www.topuniversities.com/qs-stars 
інтернаціоналізацію; 6) інфраструктуру; 7) онлайн та дистанційне навчання; 8) інновації; 9) соціальну відповідальність; 10) культуру та мистецтво; 11) інклюзивність; 12) специфічні напрямки діяльності ${ }^{58}$. Детально про відповідні індикатори та процес реалізації проекту можна прочитати у брошурі QS Stars Development Roadmap - QS University ${ }^{59}$, розміщеній у вільному доступі. «QS Stars допоможе вам зрозуміти сильні та слабкі сторони закладу вищої освіти незалежно від його позицій у рейтингу. Після збору даних та їх аналізу, наша команда розробить для вас інституційну стратегію розвитку, яка буде включати детальні матеріали про ваші сильні сторони та рекомендації щодо їх подальшого вдосконалення» - зазначають розробники цього проекту ${ }^{60}$. Більш детальну інформацію щодо можливої участі у QS Stars University Ratings можна отримати від його комерційного директора, Jason Newman, за адресою: jason@qs.com .

Процес входження закладів вищої освіти до третього авторитетного міжнародного університетського рейтингу THE World University Rankings або рейтингу Таймс описаний у статті How to participate in Times Higher Education Rankings ${ }^{61}$, розміщеній на офіційному сайті рейтингу ${ }^{62}$. Слід відзначити, що критерії та індикатори цього рейтингу спираються як на об'єктивні, так і на суб'єктивні дані, та охоплюють більше аспектів університетської діяльності, ніж Шанхайський рейтинг та рейтинг QS. Тому, на мою думку, «запропонований розробниками THE World University Rankings підхід найповніше відображає сучасну університетську реальність у порівнянні 3 двома попередніми рейтингами» ${ }^{63}$. Існують три критерії, яким повинні відповідати заклади вищої освіти для того, щоб увійти в рейтинг: 1) мати не менше 1000 наукових статей, надрукованих співробітниками впродовж останніх 5 років; 2) викладати, починаючи із рівня бакалавра; 3) здійснювати підготовку за різними напрямками діяльності ${ }^{64}$. Якщо заклад вищої освіти відповідає цим критеріям, для того, щоб розпочати співпрацю, треба написати листа на адресу: profilerankings@timeshighereducation.com із інформацією про особу, яка буде відповідальною за співпрацю із укладачами рейтингу. Потім ця особа отримає листа із детальною інформацією про те, які дані потрібні для можливого входження до рейтингу, та як розміщувати ці дані на відповідному веб-порталі. Детальна інформація про це міститься у THE World University Rankings: Your Brief Guide to Data Submission ${ }^{65}$, який розміщений у вільному доступі.

${ }^{58}$ QS Stars: Methodology. URL: https://www.topuniversities.com/qs-stars/qs-stars-methodology

${ }^{59}$ QS Stars Development Roadmap. QS University. - URL: https://content.qs.com/qsiu/QS Stars Development Roadmap (sample).pdf

${ }^{60}$ QS Intelligence Unit. URL: http://www.iu.qs.com/services/qs-stars/

${ }^{61}$ How to participate in Times Higher Education Rankings. URL: https://www.timeshighereducation.com/how-participate-timeshigher-education-rankings

${ }^{62}$ Times Higher Education Rankings. URL: https://www.timeshighereducation.com/

63 Курбатов, С. Стратегії вищої освіти в умовах інтернаціоналізації: проблема якості. URL: https://ihed.org.ua/wpcontent/uploads/2019/08/Analiz strategiy VO v umovah internac ch1 analit IVO-2018-113p avtors-kolektiv.pdf

${ }^{64}$ How to participate in Times Higher Education Rankings. - URL: https://www.timeshighereducation.com/how-participate-timeshigher-education-rankings

${ }^{65}$ THE World University Rankings: Your Brief Guide to Data Submission. URL: https://www.timeshighereducation.com/sites/default/files/data submission_pack _- 


\section{Список використаних джерел}

1. Дебич М. Теоретичні засади інтернаціоналізації вищої освіти: міжнародний досвід: монографія. Ніжин: ПП Лисенко. 2019. 408 с.

2. Закон України Про вищу освіту. URL: https://zakon.rada.gov.ua/laws/show/1556-18 (дата звернення: 09.12.2019).

3. Закон України Про освіту. URL: https://zakon.rada.gov.ua/laws/show/2145-19 (дата звернення: 09.12.2019).

4. Курбатов, С. Рейтингові системи як «флюорографія». С. 3. URL: http://essuir.sumdu.edu.ua/handle/123456789/70815 (дата звернення: 05.12.2019).

5. Курбатов, С. Стратегії вищої освіти в умовах інтернаціоналізації: проблема якості. URL: https://ihed.org.ua/wp-content/uploads/2019/08/Analiz_strategiy_VO_v_umovah_internac_ch1_analit_IVO-2018113p_avtors-kolektiv.pdf (дата звернення: 05.12.2019).

6. Курбатов,С. Університетські рейтинги як альтернативний механізм освітніх вимірювань. Рідна школа. 2017. № 1-2. С. 3-6.

7. Національне агентство із забезпечення якості вищої освіти. URL: https://naqa.gov.ua/ (дата звернення: 09.12.2019).

8. Постанова Кабінету Міністрів України № 1146 «Про розподіл видатків державного бюджету між закладами вищої освіти на основі показників їх освітньої, наукової та міжнародної діяльності» від 24 грудня 2019 року. URL: https://zakon.rada.gov.ua/laws/show/1146-2019-\%D0\%BF (дата звернення: 27.12.2019).

9. Преобразование нашего мира: повестка дня в области устойчивого развития на период до 2030 года. URL: https://undocs.org/ru/A/RES/70/1 (дата звернення: 08.12.2019).

10.Стандарти і рекомендації щодо забезпечення якості в Європейському просторі вищої освіти ESG. URL: http://www.britishcouncil.org.ua/sites/default/files/standards-and-guidelines_for_qa_in_the_ehea_2015.pdf (дата звернення: 09.12.2019).

11.Український державний центр міжнародної освіти Міністерства освіти і науки України. URL: https://studyinukraine.gov.ua/ (дата звернення: 10.12.2019).

12.About Global Research University Profiles. URL: http://www.shanghairanking.com/grup/survey/aboutGRUP-Survey.html (accessed:: 06.12.2019).

13.Academic Ranking of World Universities. URL: http://www.shanghairanking.com/index.html (accessed:: 06.12.2019).

14.Angel Oi Yee Cheng Global Mission - "Glocal" Internationalization: United Nations Academic Impact (UNAI) and Lehigh University. Journal of Comparative and International Higher Education. 2019. \# 11. P. 41-51.

15.Beck, Kumari \& Roumiana llieva "Doing" internationalization: principles to practice. Simon Fraser University Educational Review. 2019. Vol. 11. \# 3. P. 18-39.

16.Demystifying the Rankings: A Guide for Universities. URL: https://www.qs.com/portfolioitems/demystifying-the-rankings-a-guide-for-universities/?utm_source=qswebsite\&utm_medium=blog (accessed:: 06.12.2019).

17.GRUP Survey. URL: http://www.shanghairanking.com/grup/survey/index.html (accessed:: 07.12.2019).

18. Hantian Wu Three dimensions of China's "outward-oriented" higher education internationalization.

Higher Education.2019. Vol. 77. \# 1. P. 81-96.

19. How to participate in Times Higher Education Rankings . URL: https://www.timeshighereducation.com/how-participate-times-higher-education-rankings (accessed:: 07.12.2019).

20.Linney, Sarah How to Enter QS World University Rankings. URL: https://www.qs.com/how-enter-qsworld-university-rankings/ (accessed:: 07.12.2019).

21.QS Stars University Ratings. URL: https://www.topuniversities.com/qs-stars (accessed:: 07.12.2019).

22. QS Stars Development Roadmap - QS University. URL:

https://content.qs.com/qsiu/QS_Stars_Development_Roadmap_(sample).pdf (accessed:: 07.12.2019).

23. QS World University Rankings. URL: https://www.topuniversities.com/qs-world-university-rankings (accessed:: 07.12.2019).

24.SWOT analysis. URL: https://en.wikipedia.org/wiki/SWOT_analysis (accessed:: 09.12.2019).

25. The United Nations Academic Impact. URL: https://academicimpact.un.org/ (accessed:: 07.12.2019).

26.THE World University Rankings. URL: https://www.timeshighereducation.com/world-universityrankings (accessed:: 08.12.2019). 
27.THE World University Rankings: Your Brief Guide to Data Submission . URL:

https://www.timeshighereducation.com/sites/default/files/data_submission_pack_

_times_higher_education_world_university_rankings_06122018_v2.pdf (accessed: 08.12.2019).

28.UNESCO. URL: https://en.unesco.org/ (accessed: 09.12.2019).

29. United Nations. URL: https://www.un.org/en/ (accessed: 09.12.2019). 


\title{
Розділ V. Особистісні та гуманістичні стратегії вищої освіти для стійкого розвитку: шляхи реалізації
}

\author{
Юрій Мєлков, \\ доктор філософських наук, \\ провідний науковий співробітник \\ відділу інтернаціоналізації вищої освіти \\ Інституту вищої освіти НАПН України \\ https://orcid.org/0000-0002-8186-0357
}

Анотація. Роботу присвячено розгляду можливих иляхів реалізації стратегій вищої освіти в умовах інтернаціоналізації для стійкого розвитку суспільства у зВО України. Висловлені методичні рекомендації грунтуються на теоретичній концепції, згідно з якою соціальний, економічній та екологічний вектори подальщого поступу суспільства поєднуються в одній площині стійкості завдяки всебічному розвитку людської особистості, яка виступає носієм і суб'єктом суспільних цінностей, яка здатна втілювати відповідні настанови у власній життєдіяльності та формування якої є загальною метою сучасного університету. В якості запропонованих можливих практик підготовки подібної особистості виступають такі розглянуті напрями, як-от: екологічна освіта; реалізація інвайронменталістського підходу в управлінні університетським кампусом та стратегія деурбанізації зВО; десормалізація та індивідуалізація навчального процесу в дусі навчання, «центрованого» на особистості; гуманітаризація навчальних програм з акцентом на формування критичного мислення; застосування постнекласичної методології як засобу, що уможливлює конкретне мислення «єдності в багатоманітності»; та активне застосування Інтернет-технологій і онлайн-платформ. 


\section{Стійкий розвиток і його реалізація у вищій освіті: постановка проблеми та аналіз існуючих підходів}

Проблематика стійкого розвитку людської цивілізації, виражена зокрема у вигляді низки окремих цілей і настанов у тексті прийнятої у вересні 2015 року Резолюції ООН «Порядок денний 2030 для стійкого розвитку (Перетворюючи наш світ)» ${ }^{1}$, становить собою один із найбільш реальних орієнтирів щодо оптимізації соціального, економічного та екологічного векторів поступу людської цивілізації. Втілення такого порядку денного вимагає свого роду світоглядної революції та формування фахівців, громадян і просто особистостей, здатних реалізовувати у своєму житті цілі ліквідації бідності в усіх їі проявах і вимірах, слідування політиці всезагального миру та захист планети, мінімізуючи свій «екологічний слід» і руйнівні наслідки своєї діяльності. Очевидно, що для такого масштабного зрушення недостатньо досягнення лише однієї - четвертої із проголошених у резолюції ООН сімнадцяти цілей, яка вимагає забезпечити інклюзивну та справедливу якісну освіту та сприяти можливостям навчання протягом усього життя для всіх, - і освіта, зокрема освіта вища, постає перед нами як один із вирішальних факторів формування суб'єкта стійкого розвитку загалом і потенційним каталізатором такого розвитку у смисловому горизонті прийдешнього покоління.

На думку багатьох міжнародних дослідників і аналітиків ${ }^{2}$, університети $\epsilon$ ключовими для забезпечення реалізацій стратегій стійкого майбутнього, проте перехід від загальних гасел і декларацій, що лунають у різноманітних програмах політиків, національних урядів і міжнародних організацій, до конкретного плану дій на рівні ЗВО є справою далеко не очевидною. Наприклад, один із щорічних звітів щодо стійкості в освіті, що публікується британським союзом студентів та іншими асоціаціями на підставі результатів опитів, демонструє, що близько третини опитуваних співробітників відзначили стійкість як стратегічний пріоритет для закладу, в якому вони працюють, але лише 1\% вважає, що їх університети роблять все, що від них залежить, для реалізації настанов такого розвитку ${ }^{3}$.

Серед вітчизняних ЗВО подібне опитування, на жаль, не проводилося; загалом, аналіз стратегічних планів і програм таких закладів демонструє майже повну відсутність урахування настанов стійкого розвитку в діяльності провідних університетів України. Приміром, у програмі Київського національного університету імені Тараса Шевченка відсутні будь-які згадки про стійкий розвиток, а інвайронменталістська проблематика згадується лише в контексті створення сучасного інформаційного середовища: «3 екологічних та фінансових міркувань обладнати централізовані служби комп'ютерного друку у підрозділах з системами обліку друкованої продукції» ${ }^{4}$. Харківський національний університет імені В. Н. Каразіна перелічує у своїй програмі розвитку «формування і розвиток інформаційно-керуючих систем підтримки прийняття рішень щодо формування комплексного сталого розвитку регіонів України» ${ }^{5}$ проміж численних інших завдань фундаментальних і прикладних досліджень у галузі «гуманітарні технології», але про втілення результатів таких досліджень у навчальний процес мова також не йде. Стратегія розвитку Національного технічного університету України «Київський політехнічний інститут» згадує поняття стійкого (сталого) розвитку серед основних концептуальних положень, доречно підкреслюючи його залежність від рівня фундаментальності вищої освіти: «Людина, що отримала глибоку фундаментальну освіту, здатна формулювати складні завдання, керувати процесами, комплексно, системно оцінювати усі наслідки тих чи інших управлінських рішень і лише вона здатна створювати умови для сталого розвитку суспільства» ${ }^{6}$ Втім, у подальшому тексті, у плані дій 3

\footnotetext{
${ }^{1}$ Transforming our world: the 2030 Agenda for Sustainable Development : Resolution adopted by the General Assembly on 25 September 2015. - URL: https://www.un.org/ga/search/view doc.asp? symbol=A/RES/70/1\&Lang=E. 35 p.

2 Mattis G. How to Improve Sustainability in Higher Education. - URL: https://www.qs.com/improve-sustainability-highereducation/; Toporas A. Higher Education for Sustainable Development. - URL: https://moderndiplomacy.eu/2018/02/26/higher-educationsustainable-development/, тощо.

${ }^{3}$ Sustainability in Education 2017 : Survey research by the Environmental Association for Universities and Colleges, National Union of Students, University and College Union, Association of Colleges and the College Development Network. 55 p. - URL: https://s3-eu-west1.amazonaws.com/nusdigital/document/documents/38977/20180122_State_of the sector_report_2017_FINAL.pdf.

${ }^{4}$ Стратегічний план розвитку Київського національного університету імені Тараса Шевченка на період 2018-2025 року. С. 10. - URL: http://www.univ.kiev.ua/pdfs/official/Development-strategic-plan.pdf.

${ }^{5}$ Програма розвитку Харківського національного університету імені В. Н. Каразіна на 2010-2020 роки. С. 18. - URL: https://www.univer.kharkov.ua/docs/polozhennya/program2010-2020n.pdf.

${ }^{6}$ Стратегія розвитку НТУУ «КПІ» на 2012-2020 роки (концептуальні положення) та план дій щодо ії виконання / Уклад.: Ю. І. Якименко, М. Ю. Ільченко, Г. Б. Варламов та ін.; під заг. ред. М. З. Згуровського. К. : НТУУ «КПІ», 2012. C. 7. - URL: http://dpr.kpi.ua/wpcontent/uploads/2016/06/Strategiva-rozvitku-NTUU-KPI-na-2012-2020-roki.pdf.
} 
реалізації визначеної стратегії стійкість ніде більш не згадується, а власне фундаменталізацію підготовки фахівців даний ЗВО планує здійснювати виключно за фізико-технічною моделлю, із синтезом глибоких загальнонаукових природничих знань та інженерного мистецтва, виключаючи роль знань гуманітарних і загальнокультурних. Чи не єдиним, але закономірним винятком серед українських ЗВО виступає Національний університет біоресурсів і природокористування України, діяльність якого за визначенням орієнтована на екологічну тематику. Зокрема, викладаються й окремі курсі зі стійкого розвитку, в яких викладено теоретичні його засади, економічні механізми раціонального природокористування тощо, й навіть проблематика освіти для стійкого розвитку, серед настанов якої відмічаються пропаганда знань про стан довкілля, розповсюдження ідей та інформації з питань збереження довкілля, підготовка викладачів і лекторів з питань міждисциплінарних екологічних зв'язків тощо․

Екологічна освіта дійсно виступає одним із напрямів освіти для сталого розвитку, але вважати його не просто необхідним, але й самодостатнім, зводячи таку освіту лише до пропаганди екологічних знань, буде не зовсім правильною методичною рекомендацією. Адже мова йде про необхідність цілісного бачення проблем стійкості, подібно до того, як сама ця концепція обіймає і соціальні, і економічні сторони буття, тобто, про те, що не лише окремі дисципліни та галузі знання, але вся вища освіта в цілому має нести в собі світогляд стійкого розвитку (і обмежуватися підготовкою фахівців суто в галузі природокористування й в одному лише закладі вочевидь неефективно). Крім того, й до простого “розповсюдження знань», нехай корисних і актуальних, завдання вищої освіти зводити аж ніяк не можна. Подібну точку зору детально обґрунтовує зокрема новозеландський дослідник проблеми вищої освіти для стійкого розвитку K. Shephard, описуючи зокрема безглуздість викладачів, які на словах підтримують відповідні гасла та претендують на турботу про стійкість, але на практиці ще продовжують викладати традиційні дисципліни з менеджменту, суспільні науки або певною мірою фізику так, нібито знання в цих дисциплінах досі залишаються цінно нейтральними та незалежний від навколишнього світу. Іншим словами, вища освіта для стійкого розвитку суперечить тим застиглим традиціям університетського викладання, за яких викладачі мають монопольне право «вирішувати що викладати та як викладати», а виховальна сторона навчального процесу зводиться до того, щоби допомогти студентам «знайти своє місце у суспільстві», а не примушувати їх до певних заздалегідь визначених рамок.

Оскільки ж подолати подібні традиції не так уже і просто, K. Shephard пропонує два різних плани втілення освіти для стійкого розвитку у навчальний процес сучасного університету. Тоді як «План А» передбачає безпосереднє навчання студентів стійкості, тобто настановам і основним рисам концепції стійкого розвитку суспільства (проста «екологічна освіта», про яку ми казали вище), «План Б», запропонований цитованим дослідником, внаслідок аналізу опитувань кількох десятків науково-педагогічних працівників шести університетів п'яти різних країн, становить собою спробу «знайти спільну мову» з тими викладачами, хто не є прибічниками «навантаження» вищої освіти тематикою стійкого розвитку. Мова йде про акцентуванні на виховання якостей і компетентностей, які, на перший погляд, не мають безпосереднього відношення до тематик стійкого розвитку суспільства, але на справі виявляються вирішальним для реалізації відповідних настанов, - і передусім це акцент на навчанні студентів мислити критично 9 .

\footnotetext{
${ }^{7}$ Стратегія сталого розвитку природи та суспільства: Навчально-методичний посібник / В. А. Прилипко, В. М. Боголюбов, Л. Е. Піскунова. К. Видавничий центр НАУ, 2008. С. 109.

${ }^{8}$ Shephard K. Higher Education for Sustainable Development. Basingstoke : Palgrave; Macmillan, 2015. P. 41.

${ }^{9}$ Ibid. P. 85
} 


\section{Особистісний вимір освіти для стійкого розвитку: від гасел до реалізації}

Виховання критичного мислення $є$ вже безперечно визнаною настановою, що відповідає як викликам кризової ситуації, - зокрема й у нещодавній доповіді Римського клубу саме розвиток у студентів критичного, незалежного та самостійного мислення був проголошений ключовим фактором «освіти для стійкої цивілізації» ${ }^{10}$. Зрозуміло, що вміння критично мислити відноситься до загальноосвітніх, загальнокультурних якостей особистості, і якщо вища освіта не може претендувати, власне кажучи, на те, щоби навчити мислити критично людину, яка не має схильності це робити після школи, та й загалом будучи вже повнолітнім і самостійним громадянином, вона все ж таки може та має розбудовувати свої навчальні програми таким чином, щоби всіма можливими засобами сприяти посиленню та реалізації такої якості.

Загалом, із цим завданням - або, точніше сказати, з невірним його розумінням - пов'язане й означене вище утруднення перекладу гучних гасел і декларацій на мову практичних методичних рекомендацій для університетів, яке обумовлене традиційними уявленнями про те, що соціальні навики, на відміну від професійних, мають виховувати начальна чи середня школа, тоді як на долю вищої школи залишається тільки одна науково-дослідницька діяльність. Годі й казати в цьому плані про особистісні якості студента: останнім часом висловлюються навіть думки на кшталт того, що й завданням середньої школи не може бути виховання, яке є справою виключно сімейною. Можна зрозуміти дещо застережливе ставлення до ціннісних підвалин освіти на наших теренах, коли акцент на світоглядній, виховальній, загалом аксіологічній стороні навчального процесу може здаватися відлунням надмірної ідеологізації доби радянського періоду. Втім, західні дослідники, що є вільними від подібних конотацій, стверджують достатньо недвозначно: завдання освіти, й насамперед освіти вищої, не може бути здійсненим без того, щоби змінити «нестійку» поведінку студента, привівши йому відповідні цінності стійкого розвитку. Більше того: відсутність таких практик в університетському навчанні часто пояснюється просто небажанням викладачів змінювати свої архаїчні погляди щодо своєї викладацької діяльності та переходити від «викладання знань» до «викладання цінностей». На думку деяких авторів, справа не в тому, що професори не розуміють важливості засад стійкості, але в тому, що вони поки що не хочуть брати на себе відповідальність за те, щоби змінити глибоко вкорінені погляди та способи поведінки студентів ${ }^{11}$.

Проте, в контексті подібного ставлення мова йде зокрема про стратегічну трансформацію - перехід до так званої «освіти, орієнтованої на студента» (або «студентоцентрованого навчання» - student-focused, student-centred learning), аж до ідей всебічного розвитку особистості (whole-person development, all-round development) як необхідного доповнення до формування у студентів базових і фахових знань і вмінь для максимально повного розкриття їх людського потенціалу в якості майбутніх лідерів і просто учасників життєдіяльності суспільства. Про необхідність «поважати автономію студента» говорив і один із провідних освітніх мислителів XX століття Paolo Freire ${ }^{12}$. В Україні дана ідея тільки починає осмислюватися; зокрема, як раз зараз, наприкінці 2019 року у Верховній Раді опрацьовується законопроект, який пропонує внести зміни до Закону України «Про вищу освіту» 2014 року, доповнивши його відповідними визначеннями понять і концепцій ${ }^{13}$ :

«Студентоцентроване навчання - підхід до організації освітнього процесу, який передбачає:

- заохочення здобувачів вищої освіти до ролі автономних і відповідальних суб'єктів освітнього процесу;

- створення освітнього середовища, орієнтованого на задоволення потреб та інтересів здобувачів вищої освіти, включаючи надання можливостей для формування індивідуальної освітньої траєкторії;

- побудову освітнього процесу на засадах взаємної поваги і партнерства здобувачів вищої освіти та адміністрації, педагогічних, науково-педагогічних, наукових та інших працівників закладу вищої освіти».

Звісно, мова йде не про те, що до цього освіта була нібито «орієнтованою на викладача», замість того, щоб «орієнтуватися на студента»: скоріше, мається на увазі та виходить на перший план орієнтація на

\footnotetext{
${ }^{10}$ Weizsäcker E., Wijkman A. Come On! Capitalism, Short-termism, Population and the Destruction of the Planet - A Report to the Club of Rome. New York : Springer Verlag, 2018. P. 196.

${ }^{11}$ Toporas A. Higher Education for Sustainable Development. - URL: https://moderndiplomacy.eu/2018/02/26/higher-educationsustainable-development/

${ }^{12}$ Freire P. Pedagogy of Freedom: Ethics, Democracy, and Civic Courage. Lanham, MD : Rowman \& Littlefield, 2001. P. 59.

13 Проект Закону про внесення змін до деяких законодавчих актів України щодо вдосконалення освітньої діяльності у сфері вищої освіти (Проект 22.10.2019) // Офіційний портал Верховної Ради України. - URL: http://w1.c1.rada.gov.ua/pls/zweb2/webproc34?id=\&pf3511=67164\&pf35401=506119. . . 2.
} 
особистість не тільки студента, але і викладача - всупереч лінійно-модерновій орієнтації на формальність навчання, на стандартні, сталі та незмінні, як позначено у законопроекті, «освітні траєкторії». Тобто, йдеться про деформалізацію навчального процесу та його переорієнтацію на культивацію творчого начала як у студента, так і у викладача. Така постановка питання означає й докорінну демократизацію: не абстрактний «студент узагалі» має потрапити у фокус освітнього процесу, а кожний окремий реальний студент має перетворитися на суб'єкта організації такого процесу - разом із викладачем, який буде мати можливість та потребу адаптувати під окремого студента, його здібності та інтереси свою навчальну програму, - тобто, мова йде про індивідуальний, особистісний, гуманістичний підхід у практиці вищої освіти.

Гуманістичність у плані змісту передбачає й акцент на гуманітарному пізнанні, і передусім на пізнанні філософському, яке й покликане допомогти студентові активізувати в себе критичне, самостійне, незалежне мислення. $€$ сенс рекомендувати закладам вищої освіти не йти шляхом скорочення годин на дисципліни загальнокультурного та філософського циклу, але навпаки, спробувати здійснити переоцінку ролі філософії та гуманітарних наук у вищій школі. Мабуть, методична ідея щодо того, що ці напрями університетської підготовки не є обов'язковими для фахівців інших галузей знань, витікає з ідеї «двох культур», яка була досить популярною в середині минулого століття, - тобто ідеї того, що природознавство становить свою власну, особливу культуру, додаткову (або навіть протилежну) щодо культури «гуманітарних наук», - ця ідея використовується для сприйняття цих двох «різновидів» культури як принципово альтернативних. I це означає, що вченому, який займається, скажімо, фізикою, потрібно вивчати закони Ньютона, але нібито зовсім не потрібно вивчати історію Стародавньої Греції, - а отже, немає потреби й витрачати час і енергію студента-фізика на вивчення дисциплін гуманітарних наук або філософії.

Однак варто нагадати собі, що всі великі вчені-природознавці від Ньютона до Ейнштейна здобули саме класичну університетську освіту, а виведення гуманітарних наук із найновішої програми виховання «професійних компетентностей» в будь-якій сфері людської діяльності здатне лише обернутися на шкоду тій чи іншій діяльності. Як стверджував відомий російський педагог О. Запесоцький ${ }^{14}$, внаслідок такого виведення вища освіта втрачає свою фундаментальну природу, яка раніше використовувалася для того, щоби дати можливість студентам формувати цілісний і систематичний світогляд, орієнтуючись на основні та узагальнюючі теорії: коли фундаментальні поняття виключаються з навчальних планів, а професійне навчання відокремлюється від набуття моральних орієнтирів, то й «університети випускають у доросле життя морально нестандартних та соціально безвідповідальних осіб, які легко знаходять виправдання будь-яких дій, пов'язаних з отриманням миттєвого прибутку».

Звичайно, неможливо заперечувати важливість здобуття випускниками ЗВО професійних знань і навичок, які $є$ необхідними для пошуку роботи після отримання університетського ступеня, - але формування в них згаданого інтегрального світогляду, моральних настанов та всього, що може бути включено до поняття вищої освіти та культури, $є$ не менш значущим, у тому числі й для суто професійної діяльності. Саме філософія, як мистецтво продукування смислів, виступає чи не найважливішою запорукою успішного формування повномірної особистості випускника закладу вищої освіти, здатного осмислювати й опрацьовувати нові, незвичні речі та явища, - інакше кажучи, мислити творчо та критично. Та й викладання філософії постає, за виразом одного з найвидатніших представників Київської школи філософії Сергія Борисовича Кримського, не стільки як передання певних ідей або ознайомлення студентів з результатами наукової творчості викладача, скільки як «трансляція особистості, без якої ці ідеї виглядають нежиттєво» ${ }^{15}$ : трансляція не тільки особистісного «неявного» знання, що його не можна почерпнути з будь-якого іншого, тим більше друкованого джерела, але й тих ціннісно-смислових структур особистості, які виступають факторами, що уможливлюють засвоєння, створення такого знання.

Проблема цих останніх аспектів освіти полягає в тому, що їх наявність важко перевірити, вони не підлягають однозначній оцінці з точки зору їх «якості», а також чіткому опису у вигляді контракту при замовленні певних «освітніх послуг» - і тому вони першими вилучаються з навчальних програм у ході переходу до того, що прагматично йменується «орієнтацією на результат», але насправді може виступити лише прагненням до тієї ж миттєвої вигоди - за рахунок нехтування майбутнім (у тому числі й у сенсі факторів, що сприяють екологічній катастрофі чи глобальному потеплінню, а також і іншими довгостроковими наслідками будь-яких помилкових дій в умовах складного та непередбачуваного світу.

\footnotetext{
${ }^{14}$ Запесоцкий А. С. Философия образования и проблемы современных реформ // Вопросы философии. 2013. № 1. С. 27.

${ }^{15}$ Крымский С. Б. Жизнь в духе / Памяти Марии Львовны Злотиной // Социология: теории, методы, маркетинг. 2000. № 4.
} 
3 іншого боку, популярне в українських 3 ВО в останні роки скорочення часів на дисципліни загального циклу зрозуміле й у плані того, що вимоги сучасності потребують приділяти стільки уваги професіональній підготовці майбутніх фахівців у будь-якій галузі діяльності, що на, здавалося б, особливо не «корисні» у професійному житті загальнокультурні курси просто не залишається часу. За відомим висловом, що приписується одному з засновників кібернетики Норберту Вінерові, наукове знання кожні п'ять років подвоюється, - і очевидно, що вища школа не може не брати до уваги таке зростання обсягу необхідних знань, збільшуючи часи на його викладання за рахунок менш привабливих дисциплін.

Втім, подібна методика є виправданою лише на перший погляд. Як раз згадане постійне збільшення наявних знань обертається рішучим недоліком стратегії відмови у вищій школі від дисциплін філософського та гуманітарного циклу: справа в тому, що «надання знань» як функція університету (принаймні, як пріоритетна його функція) належить уже минулому - і як раз тому минулому, коли порівняно невеликий обсяг такого роду знань уможливлював як «передачу» його студентам, так і ту обставину, що подібне отримане майбутніми фахівцями знання залишатиметься актуальним протягом усієї їх професійної діяльності. Сьогодні ж, за доби, що відрізняється мінливістю та плинністю, навіть фундаментальне теоретичне знання не може вже вважатися беззаперечним, а тим паче практичні навички можуть потребувати радикальної зміни вже через декілька років (подібно до того, як, скажімо, навички користування ЕОМ протягом двох десятиліть повністю змінилися з огляд на стрімке поширення інформаційних технологій і популяризацію спочатку персональних комп'ютерів, потім онлайн-технологій і вже на очах сучасної молоді - мобільних пристроїв).

А це лише підтверджує думку про те, що основною функцією університету $\epsilon$ не «передача знань і навиків», а формування у студентів здатності отримувати знання та набувати навички самостійно, - тобто, бути готовим до зміни якщо не стратегій, то тактичних прийомів своєї професійної діяльності, загалом до того, щоб жити та діяти у світі мінливому та непередбачуваному. Світ змінюється вкрай швидко, і змінюється він непередбачуваним чином, - а тому жодних «гарантованих» знань сучасний викладач студенту дати не здатний. «Втрачає сенс, відходить у минуле доба професіоналів («професіонально присвячених»), доба професій», - трохи категорично та оптимістично висловлювався з цього приводу вітчизняний педагогфілософ Валерій Босенко ${ }^{16}$. На думку мислителя, ідея політехнізму, ідея всебічного розвитку людини приходить на зміну монотехнізму, виступаючи антитезою до однобічної професійної підготовки.

Звичайно, мова сьогодні не може йти про якусь відмову від фахової природи освіти та переорієнтації закладів вищої освіти на підготовку «універсальних особистостей», з однаковим успіхом здатних набувати знання та працювати у будь-якій галузі господарства, - це виглядало би занадто утопічно. Скоріше, завдання полягає в тому, щоби підібрати вірний баланс між широтою та глибиною освітніх програм у вищий школі - та, окрім того, щоби допомогти студентам оволодіти необхідними знаннями та вміннями для конкретних професій і дисциплін, надати їм деякі відомості про інші області навчання та допомогти їм розвинути широкий кругозір, значний рівень загальної культури та отримати все необхідне для самостійного розвитку власної особистості. Про деяку діалектику тренування та навчання, про перехід від методик інформування (однобічного передання інформації з викладача до студента, тобто інструктування) до не тільки комунікації («двоспрямоване» навчання, що передбачає залучення студентів в якості повноправних суб'єктів освітнього процесу, як то слідує й із законопроекту щодо доповнення Закону України «Про вищу освіту»), але й до третьої, синтетичної парадигми вищої освіти (медіація: полівекторне, різнобічно спрямоване навчання, яке має своєю пріоритетною метою сприяння самонавчанню та організацію такого самонавчання) говорять і британські автори S. Gough та W. Scott з University of Bath, які вбачають саме в такій методичній програмі шлях успішної реалізації основних засад вищої освіти для стійкого розвитку людської цивілізації ${ }^{17}$.

\footnotetext{
${ }^{16}$ Босенко В. А. Воспитать воспитателя. Заметки по философским вопросам педагогики и педагогическим проблемам философии. К.: Всеукраинский союз рабочих, 2004. С. 160.

${ }^{17}$ Gough S., Scott W. Higher Education and Sustainable Development : Paradox and possibility. London; New York : Routledge, 2007. P. 116-118.
} 


\section{Інституціональні зрушення та новий вимір місії університету як фактор реалізації освіти для стійкого розвитку}

Зазначена вище успішна реалізація та загалом зазначена вище парадигма «студентоцентрованого навчання» передбачає побудову освітнього процесу в дусі індивідуального особистісного підходу, який, у свою чергу, можливий лише на засадах академічної свободи. Інакше кажучи, суб'єктність студента має грунтуватися на автономії університету, - останній феномен, не зважаючи на його присутність у нормативних і законодавчих актах України, поширений на наших теренах значно меншою мірою, ніж у Європі, заклади вищої освіти якої вже декілька століть продовжують традиції власної незалежності від державних органів. За висновком вітчизняного дослідника вищої освіти В. В. Зінченка, особливість України полягає у відсутності моделі Гумбольдта: в нас «майже не відома модель подвійної свободи, за якої освітній процес будується через поєднання свободи викладання та свободи навчання. У сучасній Україні гумбольдтівська ідея свободи навчання та викладання тільки починає реалізуватися в деяких університетах; загалом система освіти і надалі копіює радянську модель - а відтак відстає від європейської принаймні на півтора століття ${ }^{18}$.

При цьому дослідник пояснює, що заклики повернутися до принципів гумбольдтівської освіти і будувати новий український університет, який би нарешті спирався на ці два принципи, є дещо запізнілими, оскільки в сучасній Європі гумбольдтівська модель $€$ хоч і надзвичайно цінним надбанням, але явищем, що поступово відходить у минуле. Не можна не погоджуватися з тим, що намагання зайняти позицію постійного «наздоганання» приречене на неминучу поразку, - як у силу визнання тим своєї історично-культурної другорядності, так і у плані запізнення відповіді на сучасні виклики. Але разом із тим ці останні не стільки заперечують принцип "двох свобод», скільки доповнюють його ще одним, третім виміром сучасної вищої освіти, - водночас соціальним, економічним і екологічним. Аналізуючи стратегії розвитку вищої освіти для стійкого розвитку в регіоні Південно-Східної Азії, цей напрям можна також назвати «підприємницьким», як це робить, слідом за гонконгськими авторами, директор Centre for East Asian Studies, University of Bristol Ka Ho Mok ${ }^{19}$, чия концепція схематично зображена у Таблиці 1.

Табличя 1

Історична динаміка місій університету

\begin{tabular}{|l|l|l|}
\hline \multicolumn{1}{|c|}{ Викладання } & \multicolumn{1}{|c|}{ Дослідження } & \multicolumn{1}{c|}{ Підприємництво } \\
\hline $\begin{array}{l}\text { Збереження та } \\
\text { розповсюдження знань }\end{array}$ & Перша академічна революція & Друга академічна революція \\
\hline Єдина місія & $\begin{array}{l}\text { Дві місії: викладання та } \\
\text { дослідження }\end{array}$ & $\begin{array}{l}\text { Третя місія на додаток до двох перших: } \\
\text { економічний та соціальний розвиток }\end{array}$ \\
\hline
\end{tabular}

у будь-якому разі, «друга академічна революція» має становити радикальну трансформацію в розумінні університетом своєї місії. Без фундаментальних змін університети втратять свою центральну роль у створенні знання та дослідженні, - вказує дослідниця з Барселони Carme Gual ${ }^{20}$, розглядаючи питання про готовність сучасних ЗВО до реального впливу на досягнення цілей стійкого розвитку цивілізації. «Це одна 3 перших речей, яке потрібно вивчити університетам: 4, 5 або 6 років - це довгий час для отримання знань, які занадто часто мало пристосовані до потреб суспільства. Вища освіта перебуває на перехресті між тим, що бути актуальною, інноваційною та виступати провідником змін у нашому світі - чи стати реліктом, стародавнім способом навчання та підприємництва, що надає послуги певним елітам... Університети повинні прищепити нове етичне та трансформаційне ставлення та підготувати людей, які здатні безперешкодно вирішувати найактуальніші та найважливіші проблеми, які ми починаємо відчувати. Такі теми, як системне

18 Зінченко, В. В. Сучасні глобальні трансформації університетської системи та специфікації філософії освіти в англосаксонській та американській моделях освітньо-наукового менеджменту // Філософія освіти. Philosophy of Education. 2016 . № 1 (18). С. 109

${ }^{19}$ Mok K. H. Education Reform and Education Policy in East Asia. London; New York : Routledge, 2006. P. 130.

${ }^{20}$ Gual C. Are Universities Ready to Have a Real Impact on Achieving the Sustainable Development Goals (SDGs)? // Implementing the 2030 Agenda at Higher Education Institutions: Challenges and Responses / The Global University Network for innovation. Barcelona, 2019. P. 41-42. - URL: http://www.guninetwork.org/files/guni_publication - 
мислення, навички передбачення та комплексне вирішення проблем, мають бути в усіх університетських навчальних програмах. Міждисциплінарність повинна бути в основі знань та дій» ${ }^{21}$.

3 точки зору окремих методичних рекомендацій для таких навчальних програм нового інтегрального типу слід указати на постнекласичну методологію як на засадничу щодо міждисциплінарного підходу. у змістовному плані постнекласична парадигма вищої освіти, як філософське відображення особливостей відповідного, постнекласичного типу наукової раціональності, з його людиномірністю та врахуванням цінностей, включаючи цінності загальнокультурні, виступає методологічною базою для формування мислення нелінійного, діалектичного, мислення «єдності в багатоманітності». Основною особливістю некласичної парадигми мислення, яка зближає ії з постмодерністськими установками у філософії та мистецтві, є їі орієнтація на множинність, на альтернативність, на плюралізм - на противагу класичному монізмові й, у певному сенсі, класичній лінійності. Постнекласична ж методологія, внаслідок свого діалектичного характеру та термінологічно властивого їй подвійного заперечення, вказує не просто на плюралізм - на противагу монізму або фундаменталізму, - але на можливість подолання самої дихотомії монізму та плюралізму.

У методологічному відношенні таке розуміння постнекласичного типу мислення уможливлюється реактуалізацією у філософській думці діалектичної культури, зокрема й представленої у вітчизняній традиції. Людинорозмірні системи, що саморозвиваються, що вони становлять новий об'єкт розгляду з боку науки постнекласичної, вже в силу самого свого цього визначення є унікальними, особливими. Сучасна наука не може абстрагуватися від цієї особливості об'єктів свого розгляду, зневажуючи індивідуальні властивості системи за ради принципу ceteris paribus, - навпаки, як раз ці індивідуальні особливості і визначають специфіку розвитку системи, а тому вони і складають собою основний предмет інтересу з боку сучасного наукового пізнання. При цьому будь-яке будь-який «особливий випадок», в тому числі й у полі зору науки гуманітарної, може бути сприйнятий і оцінений в якості такого, тобто, як випадок дійсно примітний, такий, що заслуговує на науковий інтерес і на окреме вивчення, лише на тлі певних «норм», лише у співвіднесенні із загальним. Все це обумовлює як погляд на постнекласичну методологію як на таку, що поєднує в собі діалектичним чином загальне й одиничне, так і питання про статус загального в об'єктивній реальності, як і про прояснення самого поняття об'єктивності. Слід відзначити також і принципову міждисциплінарність і навіть метадисциплінарність постнекласичної методології, що відповідає зверненню пізнання та мислення до об'єктів нового типу - передусім, до об'єктів конкретних і унікальних. Будь-яка дисципліна розглядає та осмислює свій об'єкт лише з одного боку, в одному певному аспекті, - і прагнення до повноти пізнання об'єкта вимагає синтезу результатів, отриманих різними дисциплінами ${ }^{22}$.

У плані окремих компетентностей випускників 3ВО, які відповідають належному рівню розвитку їх особистості та уможливлюють ефективну життєдіяльність у будь-якій професіональній галузі у складному світі XXI століття, постнекласична методологія відповідає таким якостям, як полікультурність, розуміння багатоманітності та різноманітності світу природи та культури, вміння цінувати таку різноманітність і ставитися з повагою та толерантністю до інших культур, звичаїв, просто поглядів. Подібна настанова відповідає й стратегії інтернаціоналізації вищої освіти, якщо розглядати цю останню не в сенсі стандартизації та уніфікації, нехай на ґрунті «передових» освітніх традицій Західної Європи чи Північної Америки, а навпаки, в аспекті збереження та розвитку національних традицій - при чому не в якості протиставлення світовим тенденціям та глобальній єдності людства, а в сенсі саме єдності в багатоманітності, коли національні традиції не нівелюються, але розглядаються не як відокремлені одна від одної та не як самоцінні у своїй множинності, а як такі, що виступають компліментарними (доповню вальними) стосовно всіх інших традицій, здійснюючи свій унікальний вклад у справу розвитку людської цивілізації в цілому.

Багатоманітність не лише культурна, але й природна $€$ виразом екологічного аспекту стійкого розвитку людства. До речі, досить цікавим предметом практичного втілення стратегій модернізації освіти для стійкого розвитку виявляється культура кампусу ${ }^{23}$. Цей напрям освітніх практик, який є популярним у закладах вищої освіти Європи, Азії та Америки, не дуже відомий на наших теренах - насамперед унаслідок як раз надмірної централізації та урбанізації (в архітектурному відношенні) вітчизняної вищої освіти. Найчастіше за все, український ЗВО займає не певну окрему територію, відкритий простір, на якому розташовані

21 Ibid.

22 Мєлков Ю. О. Постнекласична наука як пізнання конкретного // Людина в складному світі : 36. наукових праць. Суми : Університетська книга, 2017. С. 212-228; Горбунова Л. С. Постнекласична раціональність: трансдисциплінарний дискурс в науці і освіті // Вісник ХНПУ імені Г. С. Сковороди. Серія «Філософія». 2019, Т. 1, №40. С. 137-152.

${ }^{23}$ Shen X. Academic Culture and Campus Culture of Universities // Higher Education Studies. 2012. Vol 2, No. 2. P. 61-65. 
різноманітні споруди університетського містечка поряд з іншої інфраструктурою, включаючи рекреаційну зону тощо, але декілька ізольованих будівель - як правило, багатоповерхових - у різних районах великого міста. Децентралізація та деформалізація вищої освіти може бути доповнена в цьому плані й таким напрямом, як деурбанізація: зменшення концентрації університетів у багатолюдних містах. Подібний можливий вектор розвитку вищої освіти в України здатний сприяти вирішенню одразу декількох проблем у всіх трьох площинах стійкого розвитку: у соціальному відношенні він може впливати на створення більш справедливого та рівномірного доступу до вищої освіти в усіх регіонах країни, в екологічному плані він зможе наблизити та повернути студентів до природи, а в економічному - зменшити витрати на споживання невідновлюваних джерел енергії.

Щоправда, деурбанізація в сенсі переведення ЗВО з великих міст і багатоповерхівок до сільської місцевості поки що може виглядати дещо утопічним. Проте, саме в наші дні ця перспектива переходить 3 царини фантастики до вельми реальної стратегії розвитку: якщо раніше, ще наприкінці XX століття, університетське навчання передбачало необхідність користуватися сховищами наукових бібліотек, якими могли похвастатися лише Київ та декілька інших центральних міст, то сьогодні, завдяки комп'ютеризації та інтернетизації, доступ до значної кількості джерел можливий в будь-який час і в майже будь-якій точці земної кулі.

Власне, питання про методику реалізації у вищій освіті настанов стійкого розвитку у практичній своїй площині багато в чому нагадує інше, більш глобальне питання: як можлива гуманістична освіта за доби стрімкого розвитку інформаційних технологій? Адже, з одного боку, для здобувачів вищої освіти відкривається доступ до практично безмежного сховища знань людської цивілізації, що, з іншого боку, призводить до радикальної зміни ролі викладача: з наставника, який володіє знаннями та здатний їх передати наступному поколінню, від перетворюється на провідника, який має допомогти своєму студентові орієнтуватися в цьому безмежному світі наявного знання, - i, передусім, як уже неодноразово зазначалося, розвивати в собі самостійне, критичне мислення, без якого простіше простого буде розгубитися в цьому океані доступної інформації.

Як зазначає, зокрема, південнокорейський дослідник Лі Сан Чхоль (Lee Sung-Chull, Hanyang University) ${ }^{24}$, протягом багатьох століть, від Середньовіччя до XX століття, університети існували лише у закритому просторі: студенти навчалися у фізичному просторі авдиторії та отримували нові знання в лабораторіях у межах кампусів. Однак поява та розвиток комп'ютерів разом із розповсюдженням інформаційних та онлайн-технологій та Інтернету призвели до третьої промислової революції на початку XXI століття. Як результат, університети зазнають значних змін на тлі такої тенденції: в якості її наслідку університети в усьому світі вже не в змозі існувати тільки в межах свого кампусу, i, перш за все, перетворюються на відкрите середовище для всього світу, оскільки поглиблення глобалізації викликає все більш активній обмін між націями ${ }^{25}$.

Зокрема, йдеться про такий напрям розвитку (та інтернаціоналізації) освіти, як електронне навчання (E-learning). Свої витоки воно веде з дистанційної форми заочних курсів, відомих іще з XIX століття; в 1996 році був відкритий перший онлайн-університет (Universitat Oberta de Catalunya у Барселоні ${ }^{26}$ ). Близько 2010 року стали з'являтися й найбільш цікаві різновиди онлайн-курсів, що відрізняються асинхронністю, - інакше кажучи, можливістю вивчати матеріали обраної дисципліни в довільному темпі, без необхідності дотримуватися режиму роботи освітнього закладу, нехай і в дистанційній формі. Такі асинхронні курси, що найчастіше позначаються абревіатурою MOOC (Massive open online courses - масові відкриті онлайн-курси), $\epsilon$ по-справжньому доступними для кожного, теоретично не мають обмежень за кількістю учасників процесу та майже не мають крайніх термінів для вивчення матеріалу. А що найголовніше, вони дозволяють людям у будь-який час і в будь-якому місці, де існує забезпечення мережею Інтернет, отримувати знання високого рівня якості: споживач освітніх послуг може легко отримати доступ до навчального контенту, який надають великі університети США, Великої Британії тощо - Harvard University, MIT, Stanford University та інші 3ВО, що входять до числа найкращих у всьому світі і з якими важко конкурувати закладам інших країн. Завдяки таким платформам онлайн-освіти, як Coursera, Udacity, edEX, FutureLearn тощо, фізичний бар'єр кампусу вже не $\epsilon$

${ }^{24}$ Lee, S.-Ch. A New Challenge for Higher Education in Korea: Social Innovation / QS Asia News Network. 2019, April $1^{\text {st }}$. URL: https://qswownews.com/a-new-challenge-for-higher-education-in-korea-social-innovation/.

${ }^{25} \mathrm{Ibid}$.

${ }^{26}$ URL: https://www.uoc.edu/portal/en/universitat/missio/index.html. 
обмеженим простором вищої освіти, і її інтернаціоналізація отримує новий вимір, більш простий у реалізації порівняно зі звичною вже академічною мобільністю.

3 іншого боку, вистачає у МООС і проблем, пов'язаних з не завжди оптимальною формою спілкування з одногрупниками або викладачами (для чого іноді, всупереч висхідній настанові на відсутність «дедлайнів», вводяться терміни проведення того чи іншого курсу, щоб забезпечити формування хай і віртуальної, але спільноти), а головне - з мотивацією студента-заочника, якого ніщо не змушує до успішного завершення навчання, крім власної дисциплінованості. Низькі показники успішності були характерні ще для неелектронних форм дистанційної освіти, і в онлайн-режимі справи нітрохи не покращилися: дослідження демонструють, що якщо на рівні старшокласників курс завершують у середньому $27 \%$ учасників, то у студентів цей показник не перевищує 8\%, а у аспірантів - 5\% ${ }^{27}$. Серед причин, що викликають відторгнення у слухачів, в опитуваннях називаються як висока складність, так і навпаки, надмірна простота курсу: далеко не в усіх викладачів виходить дотримати баланс теорії та практики, та й рівень підготовки, на який розраховані лекції та завдання, може виявитися зовсім не таким, яким його уявляв користувач при реєстрації на курс.

Цей момент дозволяє стверджувати, що «масові онлайн-курси» виступають не альтернативою і не конкурентами традиційних університетів, включаючи вітчизняні, але різновидом практики, яку можна рекомендувати в якості такої, що сприяє інтернаціоналізації та розвитку особистості студента, водночас спрощуючи деякі моменти навчальних програм. Іншими словами, різновидом «змішаної» моделі отримання вищої освіти, тобто видом додаткового навантаження для студентів, які навчаються звичайним чином в тому чи іншому університеті (як на денній, так і на заочній формі). Подібний підхід обстоюється й фундатором однієї з платформ MOOC, Khan Academy 28 , що була заснована в 2008 році американським підприємцем 3 бенгальськими корінням Salman Khan з метою створити набір онлайн-інструментів, які 6 не замінювали, а доповнювали собою традиційну університетську освіту, - без претензій на повноту, а в якості швидше допоміжного матеріалу для закріплення знань, отриманих більш звичним шляхом. Переносячи частину лекційних курсів в онлайн-форму, українські університети можуть як забезпечити своїм студентам доступ до якісного контенту міжнародного рівня, так і сприяти деформалізації та індивідуалізації процесу освіти, оскільки студент буде мати змогу навчатися у зручний для нього час і у зручному місці. 3 іншого боку, практичні завдання та перевірка знань, не кажучи вже про творчі завдання, можуть бути виконані лише при безпосередньому спілкуванні студента з викладачем, чого онлайн-курси не можуть забезпечити у принципі (i що виступає як основнім їх недоліком, так і яскравим показником того, що лише змішана форма навчання, а не повністю дистанційна, навіть із використанням новітніх технологій відеозв'язку, здатна виконувати завдання "трансляції особистості» та передачі неявного, персоналістичного знання - загалом, виступати реалізацією «студентоцентрованого навчання»). Зрозуміло, що застосування міжнародних платформ вищої освіти потребуватиме неабияких знань іноземних мов (передусім англійської) та полілінгвістичності у навчанні, проте дана стратегія розвитку освіти - це вже предмет окремого детального розгляду.

\footnotetext{
${ }^{27}$ Kizilcec R. F., Piech Ch., Schneider E. Deconstructing Disengagement: Analyzing Learner Subpopulations in Massive Open Online Courses // Proceedings of the Third International Conference on Learning Analytics and Knowledge. Stanford University, 2013. P. 3. - URL: https://web.stanford.edu/ cpiech/bio/papers/deconstructingDisengagement.pdf.

${ }^{28}$ URL - https://www.khanacademy.org. Слід відмітити також і наявність українських аналогів, таких як EdEra (URL https://www.ed-era.com) ta Prometheus (URL - https://prometheus.org.ua).
} 


\section{Висновки та рекомендації щодо можливих напрямів реалізації вищої освіти для стійкого розвитку}

Як можна бачити з розглянутих різноманітних підходів і напрямів, стратегії вищої освіти для стійкого розвитку сьогодні знаходяться ще у стані розробки свого практичного втілення у навчальному процесі, особливо в українських 3ВО, і конкретні методичні рекомендації носять лише попередній характер та мають досліджуватися більш детально у подальших розвідках з теми філософських підвалин вищої освіти. Втім, деякі потенціально потужні напрями таких стратегій вже можна сформулювати у низці методичних рекомендацій для вітчизняних викладачів і університетів. Спробуємо підсумувати запропоновані в цьому дослідженні підходи у Таблиці 2, супроводжуючи описання рекомендованих шляхів утілення стратегій вищої освіти для стійкого розвитку людської цивілізації окремими «контрольними питаннями», що могли 6 виступати показниками успішності їх реалізації у практиках навчання.

Таблиця 2

\section{Рекомендовані шляхи впровадження гуманістичної освіти для стійкого розвитку: напрями та контрольні питання}

\begin{tabular}{|c|c|c|c|}
\hline № & Напрям & Опис і рекомендації & Контрольні питання \\
\hline 1 & Екологічна освіта & $\begin{array}{l}\text { Найпростіший шлях, що відповідає старій парадигмі бачення вищої } \\
\text { освіти як системи поширення знань - у даному випадку, щодо } \\
\text { антропогенних факторів, які загрожують навколишньому середовищу, } \\
\text { та можливих способів збереження та захисту планети; екологічність як } \\
\text { один із проявів парадигми стійкості має пронизувати освіту з усіх } \\
\text { дисциплін, а не лише проблематикуприродокористування. }\end{array}$ & $\begin{array}{l}\text { Чи практикується у вашому } \\
\text { закладі екологічна просвіта? } \\
\text { Чи торкаються екологічних } \\
\text { проблем викладачі } \\
\text { гуманітарних, суспільних і } \\
\text { природничих дисциплін? }\end{array}$ \\
\hline 2 & $\begin{array}{l}\text { Деурбанізація та } \\
\text { рух «зеленого } \\
\text { кампусу» }\end{array}$ & $\begin{array}{l}\text { Найпопулярніший різновид практик стійкого розвитку у зарубіжних } \\
\text { ЗВО, який не завжди пасує до вітчизняних університетів. Утім, даний } \\
\text { напрям безпосередньо стосується управління життєдіяльністю закладу } \\
\text { та його викладачів і студентів: на рівні статутів і інституціональних } \\
\text { програм і стратегій рекомендується приймати плани дій щодо } \\
\text { мінімізації викидів шкідливих речовин, економії води та енергії. Також } \\
\text { до цього напряму відносяться різні заходи щодо сприяння формуванню } \\
\text { у студентів почутя любові до природи: «літні школи», еко-екскурсії } \\
\text { тощо. }\end{array}$ & $\begin{array}{l}\text { Чи є у вашого закладу } \\
\text { власний кампус? } \\
\text { Чи існує у закладі план дій } \\
\text { щодо збереження енергії, } \\
\text { переходу на відновлювані її } \\
\text { джерела та зменшення } \\
\text { шкідливих викидів? } \\
\text { Чи дотримуєеся ви } \\
\text { екологічної поведінки у } \\
\text { повсякденному житті? }\end{array}$ \\
\hline 3 & $\begin{array}{l}\text { Деформалізація } \\
\text { навчання та } \\
\text { індивідуалізація } \\
\text { навчальних } \\
\text { програм }\end{array}$ & $\begin{array}{l}\text { Даний напрям відповідає настанові на «студентоцентроване навчання» } \\
\text { як один із факторів формування відповідальної людської особистості, } \\
\text { здатної до життя та діяльності згідно з цілями стійкого розвитку: } \\
\text { відповідно, навчальні програми можуть складатися для кожного } \\
\text { студента, а не для академічних групи, з можливістю обирати } \\
\text { викладачів і формувати групи від одного-двох до декількох студентів } \\
\text { для кожної дисципліни окремо. }\end{array}$ & $\begin{array}{l}\text { Чи маєте ви реальну змогу } \\
\text { обирати власний план } \\
\text { навчання, } \\
\text { факультативні дисципліни? } \\
\text { Яким є, на вашу думку, } \\
\text { найбільш оптимальний } \\
\text { розмір академічної групи? }\end{array}$ \\
\hline 4 & $\begin{array}{l}\text { Гуманітаризація } \\
\text { навчання з } \\
\text { акцентом на } \\
\text { формування } \\
\text { критичного } \\
\text { мислення, } \\
\text { застосування } \\
\text { постнекласичної } \\
\text { методології } \\
\end{array}$ & $\begin{array}{l}\text { Тенденція скорочення годин і виключення з навчальних програм різних } \\
\text { спеціальностей дисциплін загальноосвітнього, гуманітарного та } \\
\text { філософського циклів має змінитися зворотнім процесом, але з } \\
\text { акцентом не на загальні дисципліни абстрактного характеру, а на більш } \\
\text { конкретизовані курси, присвячені формуванню критичного мислення } \\
\text { та наближені до філософських, етичних, соціальних засад відповідної } \\
\text { спеціальності, зокрема на грунті постнекласичної методології, } \\
\text { орієнтованої на виховання толерантності і поваги до багатоманітності } \\
\text { світу. }\end{array}$ & $\begin{array}{l}\text { Чи задоволені ви балансом } \\
\text { вузько спеціалізованих і } \\
\text { загальноосвітніх дисциплін? } \\
\text { Чи відчуваєте ви, що } \\
\text { вивчення гуманітарних } \\
\text { дисциплін сприяє вашому } \\
\text { особистісному та } \\
\text { професійному розвиткові? }\end{array}$ \\
\hline 5 & $\begin{array}{l}\text { Змішана форма } \\
\text { навчання з } \\
\text { використанням } \\
\text { онлайн-платформ }\end{array}$ & $\begin{array}{l}\text { За умов інтернаціоналізації освіти та необхідності виходу на } \\
\text { міжнародний рівень якості вітчизняним ЗВО і окремим викладачам } \\
\text { рекомендується використовувати у навчальній діяльності онлайн- } \\
\text { інструменти, зокрема МООС-платформи, тим самим деформалізуючи } \\
\text { графік навчального процесу та роблячи його більш комфортним для } \\
\text { студентів. }\end{array}$ & $\begin{array}{l}\text { Чи користуєтесь ви при } \\
\text { навчанні } \quad \text { онлайн- } \\
\text { технологіями, } \quad \text { зокрема } \\
\text { МООС-платформами? } \\
\text { Що є для вас більш зручним: } \\
\text { навчання в авдиторіях, або в } \\
\text { онлайн-режимі? }\end{array}$ \\
\hline
\end{tabular}




\section{Список використаних джерел}

1. Freire P. Pedagogy of Freedom: Ethics, Democracy, and Civic Courage. Lanham, MD : Rowman \& Littlefield, 2001. xxiv, 144 p.

2. Gough S., Scott W. Higher Education and Sustainable Development : Paradox and possibility. London and New York : Routledge, 2007. xiv, 194 p.

3. Gual C. Are Universities Ready to Have a Real Impact on Achieving the Sustainable Development Goals (SDGs)? // Implementing the 2030 Agenda at Higher Education Institutions: Challenges and Responses / The Global

University Network for innovation. Barcelona, 2019. P. 41-43. URL: http://www.guninetwork.org/files/guni_publication_-

_implementing_the_2030_agenda_at_higher_education_institutions_challenges_and_responses.pdf.

4. Kizilcec R. F., Piech Ch., Schneider E. Deconstructing Disengagement: Analyzing Learner Subpopulations in Massive Open Online Courses // Proceedings of the Third International Conference on Learning Analytics and $\begin{array}{lllll}\text { Knowledge. } & \text { Stanford } & \text { University, } & 2013 . & \text { U. }\end{array}$ https://web.stanford.edu/ cpiech/bio/papers/deconstructingDisengagement.pdf.

5. Lee S.-Ch. A New Challenge for Higher Education in Korea: Social Innovation / QS Asia News Network. 2019, April $1^{\text {st }}$. URL: https://qswownews.com/a-new-challenge-for-higher-education-in-korea-social-innovation/.

6. Mattis G. How to Improve Sustainability in Higher Education. URL: https://www.qs.com/improvesustainability-higher-education, та ін.

7. Mok K. H. Education Reform and Education Policy in East Asia. London ; New York : Routledge, 2006. xiv, $258 \mathrm{p}$.

8. Shen X. Academic Culture and Campus Culture of Universities // Higher Education Studies. 2012. Vol 2, No. 2. P. $61-65$.

9. Shephard K. Higher Education for Sustainable Development. Basingstoke : Palgrave; Macmillan, 2015. $132 \mathrm{p}$.

10.Sustainability in Education 2017 : Survey research by the Environmental Association for Universities and Colleges, National Union of Students, University and College Union, Association of Colleges and the College Development $\quad$ Network. $\quad 55 \mathrm{p} . \quad$ URL: https://s3-eu-west1.amazonaws.com/nusdigital/document/documents/38977/20180122_State_of_the_sector_report_2017_FINAL.p df.

11.Toporas A. Higher Education for Sustainable Development. URL: https://moderndiplomacy.eu/2018/02/26/higher-education-sustainable-development/

12. The University in a Garden. Pulau Pinang : Penerbit Universiti Sains Malaysia, 2003. 177 p.

13.Transforming our world: the 2030 Agenda for Sustainable Development : Resolution adopted by the General Assembly on $25 \quad$ September $2015 . \quad 35$ p. https://www.un.org/ga/search/view_doc.asp?symbol=A/RES/70/1\&Lang=E.

14. Weizsäcker E., Wijkman A. Come On! Capitalism, Short-termism, Population and the Destruction of the Planet - A Report to the Club of Rome. New York : Springer Verlag, 2018. 220 p.

15.Босенко В.А. Воспитать воспитателя. Заметки по философским вопросам педагогики и педагогическим проблемам философии. К.: Всеукраинский союз рабочих, 2004. 352 с.

16. Горбунова Л. С. Постнекласична раціональність: трансдисциплінарний дискурс в науці і освіті // Вісник ХНПУ імені Г. С. Сковороди. Серія «Філософія». 2019, Т. 1, №40. С. 137-152.

17.ЗапесоцкийА.С. Философия образования и проблемы современных реформ // Вопросы философии. 2013. № 1. С. 24-35.

18.Зінченко В.В.Сучасні глобальні трансформації університетської системи та специфікації філософії освіти в англосаксонській та американській моделях освітньо-наукового менеджменту // Філософія освіти. Philosophy of Education. 2016, № 1. С. 94-116.

19. Крымский С. Б. Жизнь в духе : Памяти Марии Львовны Злотиной // Социология: теории, методы, маркетинг. 2000. № 4. С. 182-184.

20.Мєлков Ю. О. Постнекласична наука як пізнання конкретного // Людина в складному світі : 36. наукових праць. Суми : Університетська книга, 2017. С. 212-228.

21.Програма розвитку Харківського національного університету імені В. Н. Каразіна на 2010-2020 роки. 40 c. URL: https://www.univer.kharkov.ua/docs/polozhennya/program2010-2020n.pdf. 
22.Проект Закону про внесення змін до деяких законодавчих актів України щодо вдосконалення освітньої діяльності у сфері вищої освіти (Проект 22.10.2019) // Офіційний портал Верховної Ради України. URL: http://w1.c1.rada.gov.ua/pls/zweb2/webproc34?id=\&pf3511=67164\&pf35401=506119.

23.Стратегічний план розвитку Київського національного університету імені Тараса Шевченка на період 2018-2025 року. 14 c. URL: http://www.univ.kiev.ua/pdfs/official/Development-strategic-plan.pdf.

24.Стратегія розвитку НТУУ «КПІ» на 2012-2020 роки (концептуальні положення) та план дій щодо її виконання / Уклад.: Ю. І. Якименко, М. Ю. Ільченко, Г. Б. Варламов та ін.; під заг. ред. М. З. Згуровського. К. : HTVY «KПI», 2012. 44 c. URL: http://dpr.kpi.ua/wp-content/uploads/2016/06/Strategiya-rozvitku-NTUU-KPI-na2012-2020-roki.pdf.

25.Стратегія сталого розвитку природи та суспільства: Навчально-методичний посібник / В. А. Прилипко, В. М. Боголюбов, Л. Е. Піскунова. К. Видавничий центр НАУ, 2008. 188 с. 